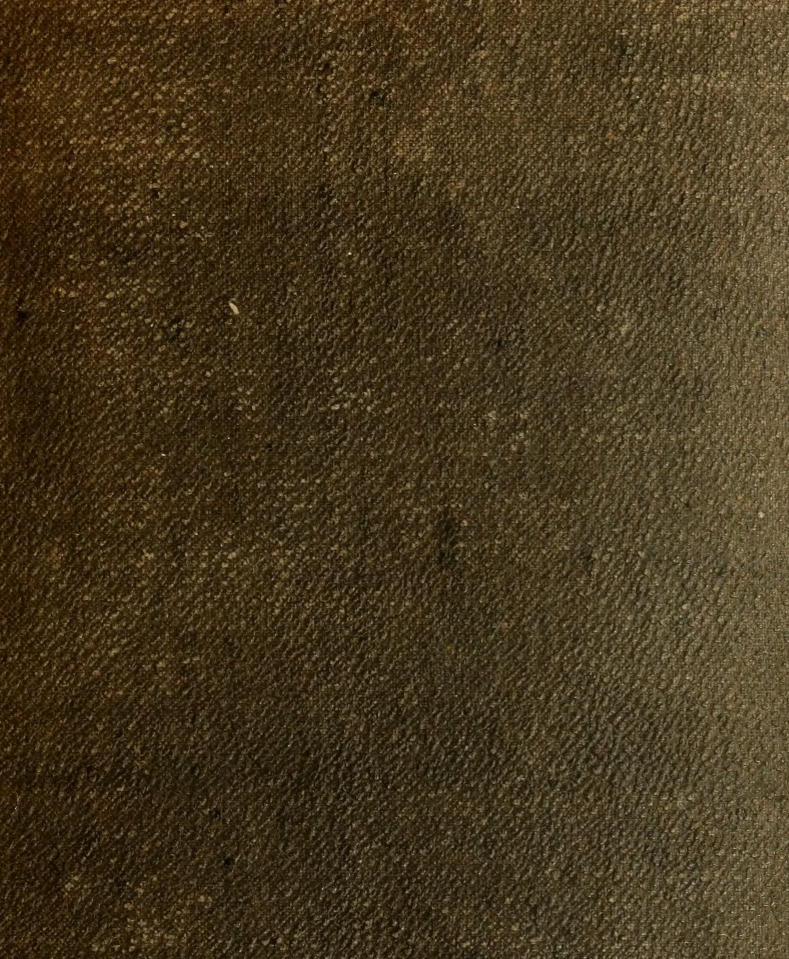

98. S.80

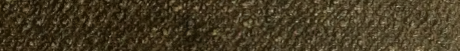

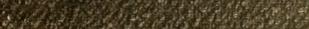

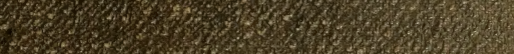
H.

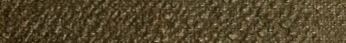




$$
\text { ฮै }
$$


mprosustu 

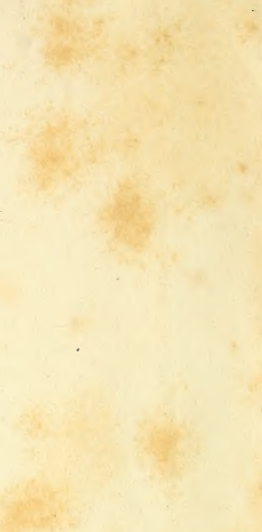
N EW $-Y$ Y N :

HARPER \& BROTHERS, 82 CLIFFST.

1836. 


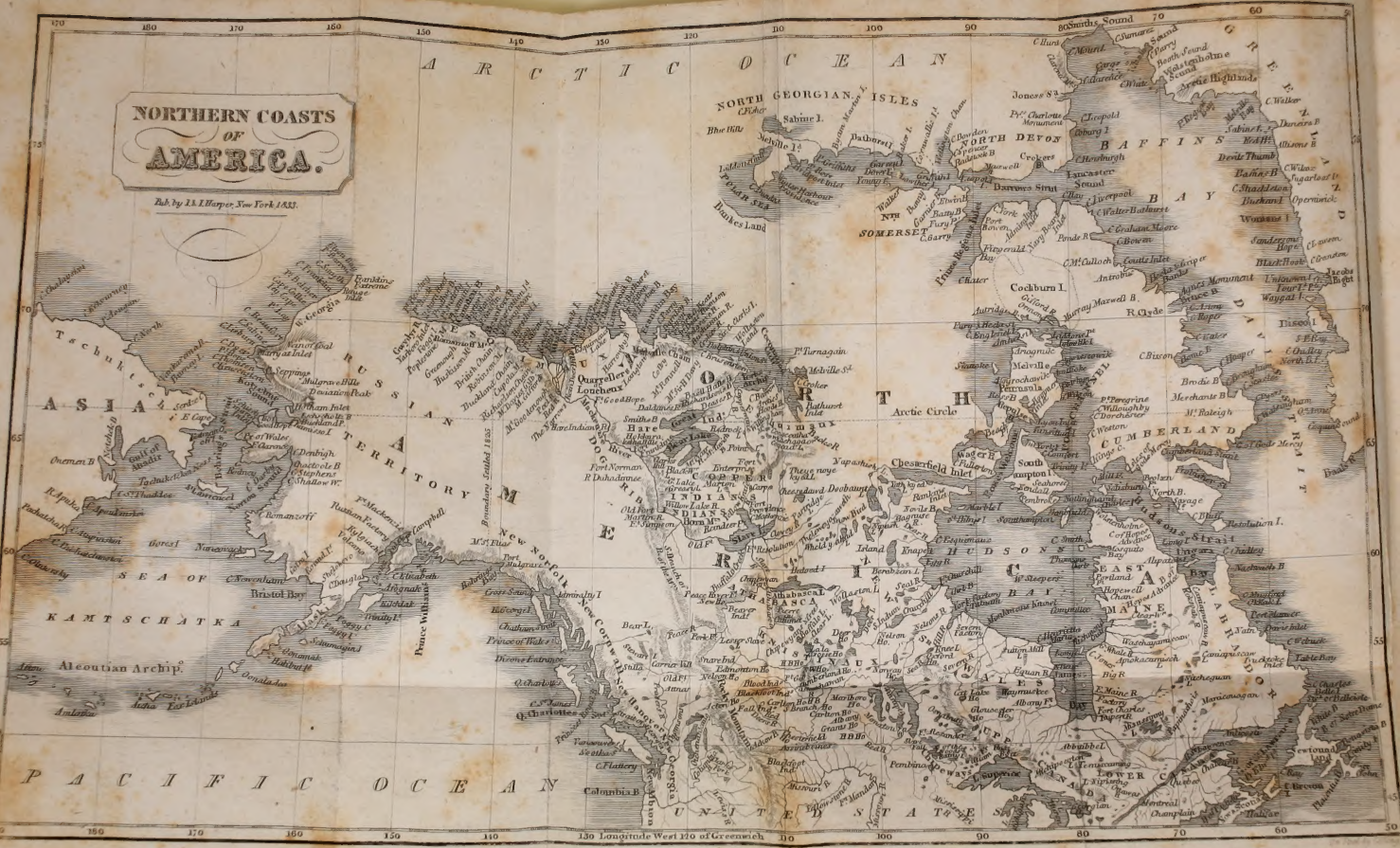




\section{chem}

Mlse Alfce H. Bushee

Jan. 6,1932

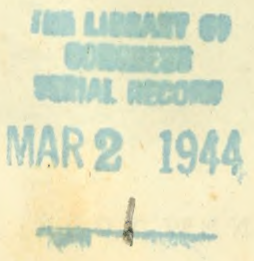

3
$\vdots$
$\vdots$ 


\section{HISTORICAL VIEW}

OF

THE PROGRESS OF DISCOVERY ON THE MORE NORTHERN COASTS

\section{OF \\ A M E R I C A,}

FROM THE EARLIEST PERIOD TO THE PRESENT TIME.

BY PATRICK FRASER TYTLER, ESQ, R.S. AND F.̈.A.A.

WITH

DESCRIPTIVE SKETCHES OF THE NATURAL HISTORY OF THE NORTH AMERICAN REGIONS.

BY JAMES WILSON, ESQ., F.R.S.E. AND M W.S.

To which is added an Appendix, containing

REMARKS ON A LATE MEMOIR OF SEBASTIAN CABOT, WITH A VINDICATION OF RICHARD HAKLUYT.

ILLUSTRATED BY A MAP AND NINE ENGRAVINGS.

\section{NEW YORK .}

HA R E R \& B ROTHER S, NO. 82 CLIFF-STRRET

1836 . 
F1060

.799

copy 2 


\section{PREFACE}

To

THE AMERICAN EDITION.

OF all the various expeditions of discovery by land or sea that have heen undertaken within the present century, none have received a larger share of attention, or been considered of more importance, than those which had for their object the extension of linowledge respecting the Arctic Regions. In no other portion of the earth's surface has the navigator to contend with such formidable impediments, or behold so peculiar an aspect of nature. The conductors of the Edinburgh Cabinet Library, one of the most able and useful series that has issued from the British press, selected the Polar Seas and Regions as the subject of their first volume (republished in the United States as No. XIV. of the Family Library), and the popularity of the work affords a strong evidence of the interest excited by its contents.

In that volume, however, the subject was but commenced; the most important intelligence from those distant and, until now, almost unknown regions has been procured by later and more success- 
ful voyagers than those whose labours were there described: we allude to the expeditions, partly by land and partly by river and coast navigation, to ascertain the limits of North America where the continent borders upon the Arctic circle. The scenery is of the same grand and impressive character, and the adventurers were exposed to hazards if possible still more striking than those encountered by the bold explorers of the polar regions. Their investigations too have made us acquainted with numerous objects, not only of the highest interest to the zoological observer, but of great value as the materials of an extensive commerce. The present volume therefore, originally published in the same excellent collection, exhibiting a full and accurate view of all that is important in modern knowledge of the most remote territories of North America, may be considered as forming a sequel to the "Polar Seas and Regions," and furnishing all that was wanting to a complete account of the whole series of northern discoveries by land and water.

Of this work the historical and critical departments have been contributed by Patrick Fraser Tytrer, Esq., the distinguished author of the History of Scotland, and the natural history by JAMES Wrison, Esq.,-two gentlemen whose names, the publishers are confident, furnish a sufficient guarantee that the task committed to them has been executed with care. The high qualifications of Mr. Wilson, the American reader has already had ample opportunities to appreciate; and we may add that, from his intimate acquaintance and correspond- 
ence with Dr. Richardson, whose name stands so high among the explorers of the northern regions, he has enjoyed peculiar advantages in preparing the interesting sketches now submitted to the public. The student of natural history who has perused the summaries of African and Indian zoology contained in the $47 \mathrm{th}, 48 \mathrm{th}$, and 49 th numbers of the FAMILY Library, will not fail to perceive their increased value when examined in connexion with that now given, inasmuch as they afford the materials of a comparative view of the animal lingdom in three principal divisions of our globe, and thereby throw a valuable light on the subject of zoological geography, which has recently excited the attention of the scientific world.

The map has been constructed with the greatest care : it comprehends all the recent discoveries on the northern boundary of America, and fully exhibits the routes of the different travellers and navigators whose adventures are recorded in the text. The engravings illustrate several striking specimens of natural history, drawn chiefly from nature, and other objects characteristic of that quarter of the globe. New-York, January, 1833. 



\section{CONTENTS.}

\section{CHAPTER I.}

\section{DISCOVERY OF NORTI AMERICA-EARLY VOYAGES OF THE PORTU GOESE, FRENCH, AND SPANIAKDS.}

First Discovery of North America by John Cabot-Voyages of Sebastian Cabot-Of the Cortereals-Discovery of Labrador-French Discoveries - Voyages of Verazzano-Of Jacques Cartier-Discovery of CanadaSpanish Voyages of Discovery - Cortes - Ulloa - Alarchon - Viscaino ........................................... Page 13

\section{CHAPTER II.}

\section{RUSSIAN AND ENGLISR VOYAGKS.}

Behring-Tchirikow-Cook and Clerke-Meares-Vancouver-Kotze bue ............................................. 58

\section{CHAPTER III.}

HEARNE AND SIR ALEXANDER MACKENZIE.

Colonization of Canada-French Fur Trade-Rise of Hudson's Bay Company-Hearne's Three Journeys-North-west Fur CompanyFirst Journey of Sir Alexander Mackenzie in 1789-His Second Expe-

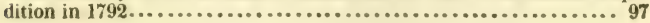

\section{CHAPTER IV.}

DISCOVERIES ALONG THE SHORES OF THE ARCTIC OCEAN.

First and Second Expeditions of Franklin-Voyage of Capt. Beechey 149

\section{CIAPTER V}

INTRODUCTORY OBSERVATIONS TO THE NATURAL HISTORY.

Amelioration in the Character of European Intercourse with uncivilized Nations-The Absence of Sandy Deserts a grand Feature in tho Physical Attributes of America-General Boundaries of the Districts 
afterwari irnatul of in I), nal - Early sinuress of Information regard ing the. Situral hictory of Norlh Aurract firmeral Viesw of the Fur-

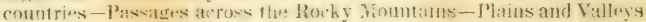
aloig the Pavilie shore............................. 210

\section{CIIAPTER VI}

THE QHADIUPEDS OY THE NORTHERN REGIONS OF AMERICA.

Inareuracies of some Ilistorical Mriters-No Monkays in North Ameried

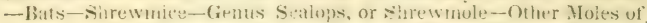
Ainerea-The Star-nose-Vanous Bears-1)iffirent disitated Ruadruprols-The Canata Otter-The Sea-otter-The Dogs and Wolves of Ameriea-The Foxes-The Beaver-The Musk-rat-Veadow Wice and bemmings-The Rocky Momman Niotoma-The American Fichlmouse-Tlue Mirmots-The Squirrel Tribe-The r'anada PoreapinrThe American Ifare-The Polar Hare-The Prairie Hare-The Iittle ('hiw Hare-frenus Cervus-The Elk, or Moose-deer-The Reindeer -The Woolland cirribou-The Roeky Mountain sheep-The Rocky Mommtain Goat-The Bison, or American Buffalo-The IIusk-ox. . 230

\section{CIIAPTER VII.}

TIE BIRDS OF THE NORTHERN REGIONS OF AMERICA.

Turliey-buzzard-finlden-eagle-Bald-eagle-Hawks-Owls-Buteherbiris - Kimg-bril-Northorn Tyrant - Ameriean Water-onzel-Reilbreasted Thrush-Blue-bird-Arcic Blue-bird-Cedar-bird, or Ameriean ('hatterer-Snow-huntung - Painted Bunting - Pine-grosbeak-Evenihy-grosbeak - Scarkt Tanaen - C'uckoo-hunting - r'rows Wondpeckers - Ifumming-hirds - Swallows - Belted Kingfisher Grouse-Passenger-plgeon - firallatores - Vatatores - Gulls-Rocky Mountan Golden-eye-Bewak's Swan-Trumpeter-swan-White Pryjean-Great Northerı Diver-Black-throated Diver-Guillemots.. 2r.t

\section{CHAPTER VIII.}

SOME ACCOUNT OF THE FISHES AND OTHER ZOOLOGICAL PRODUCTLONS OF THE NORTIERN REQIONS OF AMERICA.

Siurgeon-Salmon-Trout-Char-Capelan-White Fish-Blue FishIArring-Pike-Burhot-Pi-reh-Bull-heid-Northern Jnsects-Their Nafural Preservation from fold-More Nurthern Extmision of Tropical Forms in America than in Europe-Bees-Fxtension Westwards of the Honey-bee-Diptera-Melville Island Sputer-Butterflies.... 300

\section{CHAPTER IX.}

CIARACTERISTIC PEATYRYA IN THE BUTANY OF TIE NORTHFRN REQIUNS OF AMBIRICA.

3.Ir. Brown's Observatiens on the relative Proportions of the two great Divisions of Platmoganous Plants- Beautifil small Willow from Eavt 
Greenland-Notices of the more remarkahe Species colleried by Dr. Richardson-Galium Tinctorinm Cornus Alba-Phlox Hoodii-Viburnum Edule-Azaler Nudieaulıs-Lilium P'hiladelphicum-Epilobium Angustifolium-Lchum latifolium-I. P'alustre-P'runus Virginiana-Pyrus Ovalis-C'repis Nana-Cineraria Congesta-P'Pinus Nigra -P. Alha-P. Banksiana-P. Mierocarpa-P. Lambertiana-Empetrum Nigrum-Myriea Gale-Populus Trepida-Populus Balsamifera -Juniperus Prostrata-Splachnum Ninioides-Dicranum Elongatum -Gyrophora proboscidea-Hyperborea P'ennsylvanica, Mecklenhergii, vellea-Cetraria Richardson:i-Fueus Ceranoides-Difliculties in the Determination of Arctic Species--Plants recently introduced to the British Gardens - Lathyrus Decaphyllus-Eutora Franklinii-Lupinus Littoralis-Clarkia Pulchella-Gerardia Capitata-New Dodecatheon --Andromeda Tetragona-Menziesia Empetrifolia-Azalea Lapponica -Dryas Drummondia............................... 306

\section{CHAPTER X.}

BKETCI OF THE GEOLOGICAL FEATIRES OF SOME OF THE NORTHERP DISTRICTS OF AMKRICA.

Frozen Suhsoil of IIudson's Bay-Primitive Rocks of Hayes RiverHill River-Boriters of Kinee Lake-Remarkable Rock-island of Magnetic Iron Ore-I,ake Winineg-Limestone District-Fort ('hupewy an - Carp Lake-(ineiss Formation of the Barren Grounds-Transparent Waters of Great Bear Lake-Fort Franklin-Bear Lake River- Linnite Formation of Mackenzie River-Spontaneous Fire-Pipe ClayAlluvial Islands at the Niouth of the Nackenzie-Copper MountansCoppermine River-Islands of the Arctic Sen-Arctic Shore-Cape Barrow-Galena Point--Moore's Bay-Bankes's Peninsula-Barry's Island-Cape Croker-Point Turnagain-General Oecurrence of the New Red Sand Stone-IIood's River-Wilberforce Falls-Gneiss Formation-General Summary $\ldots \ldots \ldots \ldots \ldots \ldots \ldots \ldots \ldots \ldots \ldots, 320$

\section{APPENDIX.}

Remarios on a late Memoir of Sebastian Cabot, with a VintCation of RICHaRd HaKLUYT........................ 333 


\section{ENGRA VINGS.}

NAP of the Northern Coasts of America.......... To face the Vignetts VIGNET's - Scene near Mount Coplestone, or Western Termination of the Rocky Mountains.

Portrait of Hernan Corteg......................... Page 50

Group of Esquimaux west of the Mackenzie River ............ 192

Grizzly Bear ....................................... 238

American Gray Wolf ................................ 215

Hare Indian or Mackenzie River Dog .................... 249

Head of the American Black Elk....................... 263

Rocky Mountain Goat, and Rocky Mountain Sheep ............ 267

Eabine's Gull .......................................... 297 


\title{
PROGRESS OF DISCOVERY
}

\author{
ON THE \\ MORE NORTHERN COASTS
}

OF

\section{A MERICA.}

\section{CHAPTER I.}

Discovery of North America-Early Voyages of the Portuguese, French, and Spaniards.

First Discovery of North America by John Cabot-Voyages of Sebastian Cabot-Of the Cortereals-Disi-nvery of Labrador-French Discoveries-Voyages of Verazzano-Of Jacques Cartier-Discovery of Canada-Spanish Voyages of Discovery-Cortes-Ulloa-Alarchon-Viscaino.

When we peruse the lives of such men as De Gama and Columbus, and consider the complicated difficulties overcome by these early navigators, their imperfect means, and the dark and defective state of their knowledge, it is difficult to repress astonishment at the success. which attended their exertions, and the magnitude and splendour of their discoveries. In reflecting, indeed, upon so great a theme as the revelation of a new world, it becomes us to raise our minds from the region of second causes to the awful contemplation of that Almighty Being who confounds the calculations of man by bringing stupendous results out of the feeblest human preparations; and it is one of the finest features in the character of Columbus, that he invariably acted under the conviction of being selected by God for the task which he at length accomplished; but the admiration 
with which we regard this great man, and that belongs, though in an inferior degree, to many of his contemporaries in the field of discovery, is enhanced rather than diminished by this union of simple and primitive faith with ardent genius and undaunted resolution.

A former volume has been devoted to the description of the daring efforts which have been made to explore the Polar Seas; and we now proceed to direct our attention to another, and no less interesting and important chapter in the history of human enterprise, - the discovery of North America, and the progress of maritime adventure on the more northern coasts of this vast continent. Without detracting in any degree from the fame of Columbus, it may be mentioned as a remarkable circumstance, that although the admiral landed in Hispaniola as early as the 4th of February, 1493, he did not ascertain the existence of the continent of South America till the 30th of May, 1498 ; while there is certain evidence that, almost a year before, an English vessel had reached the shores of North America. As much obscurity hangs over the circumstances of this early voyage, and as I have arrived at a conclusion completely at variance with that adopted by a late acute writer, * it will be necessary to dwell with some minuteness on the history of this great event.

The attention paid to navigation by the commercial states of Italy, and especially by the republics of Genoa and Venice, is familiar to all acquainted with the history of Europe during the fifteenth century. Italian merchants and agents of opulent commercial houses were found settled in every European state; and the impetus communicated to the human mind by the discoveries of the Portuguese and the Spaniards rendered the sciences of cosmography and navigation the most popular subjects of instruction which were taught in the schools. A devotion to them became fashionable among the noble and ardent youths, who associated with them all that was romantic and delightful;

* The author of the Memoir of Sebastian Cabot, p. 50, 51, an anonymous work, which contaius much ingenious criticism and valuable research. It is, however, mhappily confused in its arrangement, and written throughout in a tone of asperity which, in the diseussion of a subject of remote hiography, is unpleasant and uncalled for. The author has been unjustly severe in his amimalversions on the labonrs of Hatluyt, of whom a brief Vindiea'ion will be found at the end of this velums 
they were considered as the certain guides to daring and successful maritime adventure, and the handmaids to wealth and fame. It was about this momentous period, in the year 1494, that we find a Venetian, named John C. 3ot. or Gabota, residing in the opulent city of Bristol. At whar precise time he settled in England is not now discoverable; we only know that he left Italy for the purpose of devoting himself to the mercantile profession. He was one of those enthusiastic spirits upon whom the career of Columbus made a deep impression; and about a year after the return of the great Genoese from his first voyage, the merchant of Bristol appears to have embraced the idea that new lands might be discovered in the north-west, and a passage in all probability attained by this course to India.* Animated by such a project, Cabot addressed himself to Henry VII., and found immediate encouragement from that monarch, who, though of a cold and cautious disposition, was seldom slow to listen to any proposal which promised an increase of wealth to his exchequer. On the 5th of March, 1495, the king granted his royal commission to John Cabot, citizen of Venice, and his sons, Louis, Sebastian, and Sanchez, committing to him and them, and to their heirs and deputies, full authority to sail to all countries and seas of the east, west, and north, under the banner of England, with five ships, of whatever burden and strength in mariners they might choose to employ. The equipment of this squadron was cautiously stipulated to be made "at their own proper costs and charges ;" and its object stated to be the discovery of the isles, regions, and provinces of the beathen and infidels which hitherto had been unknown to all the nations of Christendom, in whatever part of the globe thev might be placed. By the same deed the Cabots were ems swered to set up the banners and ensigns of England in the newly-discovered countries; to subdue and possess them as lieutenants of the king; and to enjoy the privilege of exclusive trade : the wary monarch, however, annexing to these privileges the condition, that he was to receive the fifth part of the capital gain upon every voyage, and binding their ships to return to the port of Bristol.†

* Tiraboschi, Storia della Letter. Ital., vol. vi. b. i. cap. 6. § 24.

$\dagger$ I have nearly followed the words of this important document, which 2o still preserved. Rymer, Fodera Angliæ, vol. xii. p. 595. 
Two important facts are ascertained by this authentic document: it proves that John Cabot, a citizen of Venice, was the principal author of, and adventurer in, the project; and that no voyage with a similar object had been undertaken prior to the 5th of March, 1495.

The expedition, however, did not sail till the spring of 1497 , more than a twelvemonth subsequent to the date of the original commission. What occasioned this delay it is now difficult to determine; but as the fleet was to be equipped at the sole expense of the adventurers, it is not improbable that $\mathrm{Cabot}$ had required the interval to raise the necessary capital. It is much to be regretted that in no contenuporary chronicle is there any detailed account of the voyage. We know, however, that it was conducted by John Cabot in person, who took with him his son Sebastian, then a very young man. Its result was undoubtedly the discovery of North America; and although the particulars of this great event are lost, its exact date has been recorded by an unexceptionable witness, not only to a day, but even to an hour. On an ancient map, drawn by Sebastian Cabot, the son, whose name appears in the commission by the king, engraved by Clement Adams, a contemporary, and published, as there is reason to believe, under the eye of Sebastian, was written in Latin the following brief but clear and satisfactory account of the discovery :- "In the year of our Lord 1497, John Cabot, a Venetian, and his son Sebastian, discovered that country, which no one before his time had ventured to approach, on the 24th of June, about five o'clock in the morning. He called the land Terra Primum Visa, because, as I conjecture, this was the place that first met his eyes in looking from the sea. On the contrary, the island which lies opposite the land he called the Island of St. John, - as I suppose, because it was discovered on the festival of St. John the Baptist. The inhabitants wear beasts' skins and the intestines of animals for clothing, esteeming them as highly as we do our most precious garments. In war their weapons are the bow and arrow, spears, darts, slings, and wooden clubs. The country is steril and uncultivated, producing no fruit; from which circumstance it happens that it is crowded with white bears, and stags of an unusual height and size. It yields plenty 
of fish, and these very large; such as seals and salmon : there are soles also ahove an ell in length; but especially great abundance of that kind of fish called in the vulgar tongue baccalaos. In the same island, also, breed hawks, so black in their colour that they wonderfully resemble ravens; besides which there are partridges and eagles of dark plumage." *

Such is the notice of the discovery of North America; and as some doubt has lately been thrown upon the subject, it may be remarked that the evidence of the fact contained in this inscription is perfectly unexceptionable. It comes from Clement Adams, the intimate friend of Richard Chancelor; and Chancelor lived, as is well known, in habits of daily intercourse with Sebastian Cabot, who accompanied his father on the first voyage of discovery. Unfortunately, both the original map and the engraving are lost; but happily Purchas has preserved the information that the engraved map by Adams bore the date of 1549 ; $\dagger$ at which time Sebastian Cabot was in such great reputation at the court of Edward VI., that for his services he had received a princely pension. This young monarch, as we learn from Burnet, showed a peculiar fondness for maritime affairs. He possessed a collection of charts, which were hung up in his cabinet, and among them was the engraving of Cabot's map. The inscription, therefore, must have been seen there and elsewhere by Sebastian; and, when we consider that the date of the engraving corresponds with the time when he was in high favour with the king, it does not seem improbable that this navigator, to gratify his youthful and royal patron, employed Adams to engrave from his own chart the map of North America, and that the facts stated in the inscription were furnished by himself. The singular minuteness of its terms seems to prove this; for who but he, or some one personally present, after the lapse of fifty-two years, could have communicated the information that the discovery was made about five o'clock in the morning of the 24th June? If, however, this is questioned as being conjectural, the fact that Sebastian must have seen the inscription is sufficient to render the evidence perfectly conclusive upon the important point of John Cabot being the discoverer of North America

* Hakluyt, vol. iii. p. 6.

† Purchas's Pilgrims, vol. iii p. 807 . B 2 
That he had along with him in his ship his son Sebastian cannot, we think, in the opinion of any impartial person, detract from or infringe upon the merit of the father. But, to complete the proof, a late writer has availed himself of an imperfect extract from a record of the rolls, furnished by the indastrious Hakluyt, to discover an original document which sets the matter altogether at rest. This is the second commission for discovery, granted by Henry VII. on the $3 \mathrm{~d}$ of February, and in the thirteenth year of his reign, to the same individual who conducted the first expedition. The letters are directed to John Kabotto, Venetian, and permit him to sail with six ships "to the land and" isles of late found by the said John in our name and by our commandment." $*$ It presents a singular picture of the inability of an ingenious and otherwise acute mind to estimate the weight of historical evidence, when we find the biographer of Sebastian Cabot insisting, in the face of such a proof as this, that the glory of the first discovery of North America is solely due to Sebastian, and that it may actually be doubted whether his father accompanied the expedition at all. $\dagger$

Immediately after the discovery the elder Cabot appears to have returned to England; and on the 10th of August we find, in the privy purse expenses of Henry VII., the sum of ten pounds awarded to him who found the New Isle, which was probably the name then given to Newfoundland. Although much engrossed at this moment with the troubles which arose in his kingdom in consequence of the Cornish rebellion, the war with Scotland, and the attempt upon the crown by Perkin Warbeck, the king determined to pursue the enterprise, and to encourage a scheme for colonization under the conduct of the original discoverer. To this enterprising navigator he, on the $3 \mathrm{~d}$ of February, 1497, $\ddagger$ granted those second letters-patent just alluded to, which conferred an ampler authority and more favourable terms than the first commission. He empowered John Kabotto, Venetian, to take at his pleasure six English ships, with their necessary apparel, and to lead them to the land and isles lately found by him according to the royal command. Cabot was also permitted to receive on board all such masters, mariners, 
pages, and other subjects, as chose to accompany him; and it seems probable, from some entries in the privy purse expenses, that Launcelot Thirkill of London, Thomas Bradley, and John Carter, embarked in the adventure.*

When about to set sail on his second voyage, John Cabot, who had previously received from Henry the honour of knighthood, appears, from some cause not now discoverable, to have been prevented frum taking the command; and though the name of Sebastian was not included in the second royal commission, he was promoted to the situation left vacant by his father. He must still indeed have been a young man; but he had accompanied the first voyage, and at an early age developed that genius for naval enterprise which afterward so remarkably distinguished him. We know from his account of himself that, at the time his parents carried him from Venice to London, he had attained some krowledge of the sphere; and when about this period the great discovery of Columbus began to be talked of in England as a thing almost more divine than human, the effect of it upon his youthful imagination was to excite "a mighty longing," to use his own words, "and burning desire in his heart that he too should perform some illustrious action." $\neq$ With such dispositions we may easily imagine how rapid must have been his progress in naval science, with the benefit of his father's example and instructions. It is not matter of surprise, therefore, that, though probably not more than twenty-three years old, the conduct of the enterprise was intrusted to him. He accordingly sailed from England with two ships in the summer of 1498, and directing his course by Iceland soon reached Newfoundland, which he called Terra de Baccalaos, from the great quantity of fish of that name.

Of this remarkable voyage a short account is preserved by Peter Martyr, the historian of the New World, a writer of high authority, and so intimate a friend of the navigator,

* See Mr. Nicholas's excellent collection entitled Excerpta Historica, p. $116,117$.

The cause might be his death; but this is conjecture,-of the fact there is no direct proof; of the knighthood it is not possible to doubt. See, in the Vindication of Hakluyt, the remarks on the errors of the biog* rapher of Cabot in his chapter on this subject.

† Ramusio, Viaggi, vol. i. p. 414. 
that, at the time he wrote the passage which we now give, Sebastian was in the habit of paying him frequent visits at his house. "These northern seas," says this writer, "have been navigated and explored by Sebastian Cabot, a Venetian by birth, whom his parents, when they were setting out to settle in Britain, according to the common custom of the Venetians, who for the sake of commercial adventure become citizens of every country, carried along with them when he was little more than an infant.* He fitted out two ships in England at his own charges, and first with three hundred men directed his course so far towards the North Pole, that even in the month of July he found great heaps of ice swimming in the sea, and almost continual daylight. Yet he saw the land free from ice, which had been melted by the heat of the sun. Thus, observing such masses of ice before him, he was compelled to turn his sails and follow the west; and, coasting still by the shore, was brought so far into the south, by reason of the land bending much to the southward, that it was there almost equal in latitude with the sea called Fretum Herculeum. He sailed to the west till he had the Island of Cuba on his left-hand, almost in the same longitude. As he passed along those coasts, called by him Baccalaos, he aftirmed that he found the same current of the waters towards the west which the Spaniards met with in the southern navigations, with the single difference that they flowed more gently. From this circunstance it appears to me," says Martyr, "not only a probable, but an almost necessary conclusion, that there must exist, between both the continents, hitherto unknown, great gaps or open places, through which the waters continually pass from the east to the west. * * * Sebastian Cabot himself named these lands Baccalaos, because in the seas thereabout he found such an immense multitude of large fish like tunnies, called baccalaos by the natives, that they actually impeded the sailing of his ships. He found also the inhabitants of these regions covered with beasts' skins, yet not without the use of reason. He also relates that there are plenty of bears in these parts, which feed upon

* Cabot was born in England, and carried by his father into italy when our years old. He was anterward brought back to England when a youth, "assai giovane."-Ramusio, vol. i. p. 414. Memoir of Cabot, 2. 69 
fish. It is the practice of these animals to throw themselves into the midst of the shoals of fish, and each seizing his prey, to bury their claws in the scales, drag them to land, and there devour them. On this account, he says, that these bears meddle little with men. * * * Cabot is my intimate friend, and one whom it is my delight to have frequently under my roof; for, being called out of England by the command of the King of Castile after the death of Henry VII., he was made one of our council and assistants relating to the affairs of the new Indies; and he looks daily for ships to be fitted out for him that he may discover this hidden secret of nature. I expect," concludes Peter Martyr, " that he will be able to set out on his voyage during the course of the next year, 1516, and in the month of March."** When it is known that Sebastian Cabot's second voyagef from England to North America did not take place till 15i7, it becomes certain that the above passage, written in 1515, must relate to the expedition of 1498 ; and remembering that the author was personally intimate with this navigator, and wrote only seventeen years after the voyage had taken place, we are inclined to set a high value on such an authority. It is deeply to be regretted that the original maps drawn by so eminent a discoverer, and the discourses with which he illustrated them, are now lost; $\neq$ but in this deficiency of original materials the work of Ramusio,-a collector of

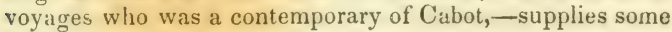
valuable information.

In the first volume of his Voyages this amusing writer has introduced a discourse upon the different routes by which the spices of the East were conveyed in ancient times to Europe ; and towards the conclusion of the essay he brings in a subject which then deeply occupied the attention of learned men,- - the project, namely, for discovering a passage to the kingdom of Cathay and the coasts of India, by the

* Peter Martyr, De Orbe Novo, 3d decad. cap. 6. Edition by Hakluyt p. 232.-Eden's Translation in Willes's Hist. of Travayle, p. 125.--The hidden secret, or natural phenomellon, of which Cabot was expected to penetrate the cause, is stated by Martyr at p. 231, - it was to resolve the question," Why the seas in these parts run with so swin a current from the east to the west ?"

$t$ Although the son accompanied the father, I consider the voyage of 1497 as solely conducted by John Cabot.

$\ddagger$ Memoir of Cabot, p. 41. 
north-west. In the discussion of this point, Ramusio minutely describes a conversation which took place at the villa of the celebrated Italian physician and poet Fracastoro, between Ramusio himself, Fracastoro, an architect named St. Michael, and a certain philosopher and mathematician, who gave them an account of an interview which he once had with Sebastian Cabot in the city of Seville. The whole passage is interesting, whether we look to the information regarding Cabot, or to the pleasing picture it brings befure us of the great Fracastoro in his philosophic and classical retreat at Caphi. No apology, therefore, need be made for presenting it to the reader. "Having thus given you," says the Italian writer, "all that I could extract from ancient and modern authors upon this subject, it would be inexcusable in me if I did not relate a high and admirable discourse which some few months ago it was my good fortune to hear, in company with the excellent architect Michael de St. Michael, in the sweet and romantic countryseat of Hieronymo Fracastoro, named Caphi, situated near Verona, while we sat on the top of a hill commanding a view of the whole of the Lago di Garda. * * * Being then, as I said, at Caphi, where we had gone to visit our excellent friend Hieronymo, we found him on our arrival sitting in company with a certain gentleman, whose name, from motives of delicacy and respect, I conceal. He was, however, a profound philosopher and mathematician, and at that moment engaged in exhibiting to Fracastoro an instrument lately constructed to show a new motion of the heavens. Having reasoned upon this point for a long time, they by way of recreation caused a large globe, upon which the world was minutely laid down, to be brought; and, having this before him, the gentleman I have mentioned began to speak to the following purpose." Ramusio, after this introduction, gives us, as proceeding from the stranger, a great mass of geographical information, after which he introduces him discussing with Fracastoro the probability of a northwest passage to India. " At this point of his conversation," says he, "after the stranger had made a pause for a few moments, he turned to us and said, 'Do you not know, regarding this project of going to India by the north-west, what was formerly achieved by your fellow-citizen the Venttian, a most extraordinary man, and so deeply conversant in 
every thing connected with navigation and the science of cosmography, that in these days he hath not his equal in Spain, insomuch that for his ability he is preferred above all other pilots that sail to the West Indies, who may not pass thither without his license, on which account he is denominated Piloto Mayor, or Grand Pilot?' When to this question we replied that we knew him not, the stranger proceeded to tell us, that being some years ago in the city of Seville he was desirous to gain an acquaintance with the navigations of the Spaniards, when he learned that there was in the city a valiant man, a Venetian born, named Sebastian Cabot, who had the charge of those things, being an expert man in the science of navigation, and one who could make charts for the sea with his own hand. "Upon this report of him," continued he, 'I sought his acquaintance, and found him a pleasant and courteous person, who loaded me with kindness, and showed me many things ; among the rest a large map of the world, with the navigations of the Portuguese and the Spaniards minutely laid down upon it; and in exhibiting this to me, he informed me that his father, many years ago, having left Venice and gone to settle as a merchant in England, had taken him to London when he was still a youth, yet not so backward but he had then acquired the knowledge of the latin tongue, and some acquaintance with the sphere. It so happened, he said, that his father died at that time when the news arrived that Don Christopher Columbus had discovered the coast of the Indies, of which there was much talk at the court of Henry VII., who then reigned in England.' " The effect of this discovery upon Cabot's youthful ambition, which we have already alluded to, is next described by Ramusio from the report of the stranger, and he then proceeds in these remarkable words :-_" ' Being aware,' said Cabot to me, 'that if I sailed with the wind bearing me in a north-westerly course, I should come to India by a shorter route, I suddenly imparted my ideas to the king, who was much pleased with them, and fitted out for me three caravels with all necessary stores and equipments This,' he added, 'was in the beginning of the summer of the year 1496, and I began to sail towards the north-west with the idea that the first land I should make would be Cathay, from which I intended afterward to direct my course to the Indies; but after the lapse of several 
days, having discovered it, I found that the coast ran lowards the north to my great disappointment. From thence Eailing along it, to ascertain if I could find any gulf to run into, $\mathrm{I}$ could discover none, and thus having proceeded as far as $56^{\circ}$ under the Pole, and seeing that here the coast trended towards the east, I despaired of discovering any passage, and after this turned back to examine the same coast in its direction towards the equinoctial,--always with the same object of finding a passage to the Indies, and thus at last I reached the country at present named Florida, where, since my provisions began to fail me, I took the resolution of returning to England. On arriving in that country I found great tumults, occasioned by the rising of the common people and the war in Scotland; nor was there any more talk of a voyage to these parts. For this reason I departed into Spain to their most Catholic majesties, Ferdinand and Isabella, who, having learned what I had accomplished, received me into their service, provided for me handsomely, and despatched me on a voyage of discovery to the const of Brazil, where I found an exceeding deep and mighty river, called at present La Plata, into which I sailed and explored its course into the continent more than sixscore leagues. * * * 'This,' continued the stranger gentleman, addressing himself to us, "is the substance of all that I learned from the Signor Sebastian Cabot." "**

Such is the passage from Ramusio ; and from it we have another proof that of this second voyage, which probably took place after the death of the original discoverer, Sebastian Cabot had the sole command; that its object was to find a north-west passage to India, and that the highest latitude which he reached was $56^{\circ}$. I am quite aware some of the statements in this extract are erroneous, and that Gomara, an author of good authority, carries Sebastian as far as $58^{\circ}$ north ; $\dagger$ but, considering the particular circumstances under which the information is conveyed, there is no reason to doubt that the general sketch of the voyage is correct: and it establishes the important fact, that as early as 1498, the coast of North America, from the latitude of $56^{\circ}$ or $58^{\circ}$ north to the coast of Florida, had been dis. covered by the English. The domestic affairs of Henry,

* Viaggi del Ramusio, tom.1. p. 413, 414

† Mlemoir of Cabot, p. 87. 
however, and the involved political negotiations with France and the continent, undoubtedly prevented the king from holding out to Sebastian that encouragement with which so great a discovery ought to have been rewarded; and after an interval of fourteen years, of which we have no certain account, this great navigator left England and entered into the service of Spain.

The Portuguese, a nation to whose genius and perseverance the sister sciences of geography and navigation owe some of their highest triumphs, were at this period in the zenith of their fame, animated with an enthusiastic spirit of enterprise, and ready to consider every discovery not conducted by themselves as an encroachment upon their monopoly of maritime glory. Inspired with this jealousy, Gaspar de Cortereal, of whose expedition notice has already been taken in this Library, ${ }^{*}$ determined to pursue the track of discovery opened by Cahot in the north-west, and in 1500 sailed with two ships from Lisbon, animated by the desire of exploring this supposed new route to India. Cortereal touched at the Azores, where he completed his crews, and took in provisions. He then steered a course never, as far as he knew, traced by any former navigator, and came upon a country to which he gave the name of 'Terra Verde, but which is carefully to be distinguished from that called Greenland. This was in truth the coast of Latrador, denominated in an old map published at Rome, in 1508, Terra Corterealis. It lay between the west and north-west ; and, after having explored it for upwards of 600 miles without reaching any termination, Cortereal concluded that it must form part of the mainland, which was connected with another region discovered in the preceding

* Discovery and Adventure in the Polar Seas, Family Library, No. XIV.; and Lives and Voyages of Drake, Cavendish, and Dampier, Ibid. No. XXX.

t Cortereal had been educated in the household of the King of Portugal before he came to the throne, and when he still bore the title of Duke de Beja.-Damiano Goes, Chronica del Rey Dom. Manuel, c. 66, cap. 66, p. 187. His character, as given by this ancient and contemporary chronicler, is brief and forcible. "Gaspar de Cortereal, son of John Vaz Cortereal, was a man of an enterprising and determined character, ardently thirsting after glory; for which reason he proposed to set out on a voyage of discovery, secking countries in morthern latitudes, we (the P'ortuguese) having at this time discovered many in southern parts." 
year in the north,- -evidently alluding to the voyage of Sebastian Cabot in 1498.* The most carious and authentic account of this remarkable expedition of the Portuguese navigator is to be found in a letter, written by Pietro Pasquiligi, the Venetian ambassador at the court of Portugal, to his brothers in Italy, only eleven days after the return of Cortereal from his first voyage. "On the 8th of October," says he, "there arrived in this port one of the two caravels which were last year despatched by the King of Portugal for the discovery of lands lying in the north, under the command of Gaspar Cortereal. He relates that he has discovered a country situated between the west and north-west, distant from this about 2000 miles, and which before the present time was utterly unknown. They ran along the coast between 600 and 700 miles without arriving at its termination, on which account they concluded it to be the same continent that is connected with another land discovered last year in the north, which, however, the caravels could not reach, the sea being frozen, and a vast quantity of snow having fallen. They were confirmed in the same opinion by finding so many mighty rivers, which certainly were too numerous and too large to have proceeded from an island. They report that this land is thickly peopled, and that the houses are built of very long beams of timber, and covered with the furs of the skins of fishes. They have brought hither along with them seven of the inhabitaits, including men, women, and children; and in the other caravel, which is looked for every hour, they are bringing fifty more. These people, in colour, figure, stature, and expression, greatly resemble gipsies: they are clothed with the skins of different beasts, but chiefly of the otter, wearing the hair outside in summer, and next to the skin in winter. These skins, too, are not sewed together, nor shaped to the body in any fashion, but wrapped around their arms and shoulders exactly as taken from the animals; while they conceal the parts which nature forbids us to expose with strong cords made of the sinews or entrails of fishes. On this account their appearance is completely savage; yet they are very sensible to shame, gentle in their manners, and better made in their arms, legs, and 
shoulders than can be expressed. Their faces are punctured in the same manner as the Indians; some have six marks, some eight, some fewer: they use a language of their own, but it is understood by no one. Moreover, I believe that every possible language has been addressed to them. They have no iron in their country, but manufacture knives out of certain kinds of stones, with which they point their arrows. They have also brought from this island a piece of a broken sword inlaid with gold, which we can pronounce undoubtedly to have been made in Italy; and one of the children had in his ears two pieces (todini) of silver, which as certainly appear to have been made in Venice,- a circumstance inducing me to believe that their country belongs to the continent, since it is evident that if it had been an island where any vessel had touched before this time, we should have heard of it. They have great plenty of salmon, herring, stockfish, and similar kinds of tish. They have also abundance of timber, and principally of the pine, fitted for the masts and yards of ships ; on which account his serene majesty anticipates the greatest advantage from this country, both in furnishing timber for his shipping, of which he at present stands in great need, and also from the men who inhabit it, who appear admirably fitted to endure labour, and will probably turn out the best slaves which have been discovered up to this time. This arrival appeared to me an event of which it was right to inform you; and if on the arrival of the other caravel I receive any additional information, it shall be transmitted to you in like manner."*

Nothing could be more cruel and impolitic than the conduct of Cortereal in seizing and carrying into captivity these unfortunate natives; and it is difficult to repress our indignation at the heartless and calculating spirit with which the Portuguese monarch entered into the adventure, contemplating the rich supplies of slaves that were to be imported from this new country. $\dagger$ It is an ingenious con-

* Memoir of Sebastian Cabot, p. 239, 240.

4 I observe that in the History of Discovery and Adventure in the Polar Seas, Mr. Murray has questioned the accuracy of the opinion stated by the biographer of Cabot, "that the objects of Cortereal's second voyage were timber and slaves," The letter, however, of Pasquiligi seems to me decisive that, if not the sole, they were at least very principal objects in the second yoyage 
jecture of the biographer of Cabot, to whose research we owe our acquaintance with this lctter, that the name Terra de Laborador was given to the coast by the Portuguese slave-merchants in consequence of the admirable qualities of the natives as labourers, and in anticipation of the profits to be derived from a monopoly of this unchristian traffic.

But distress and disaster pursued the speculation. On the 15th May, 1501, Cortereal departed on a second voyage, with a determination to pursue his discovery, and, as we may plausibly conjecture, to return with a new cargo of slaves and timber; but he was never again heard of. $A$ similar dark and unhappy fate befell his brother, Nichael de Cortereal, who sailed with two ships in search of his lost relative, but of whom no accounts ever again reacheil Portugal. The most probable conjecture seems to be that they both fell victims to the just indignation of the natives, whose wives, children, and fathers had been stolen away during their first visit to the coast. "The king," says Goes, "felt deeply the loss of these two brothers, so much the more as they had been educated by him; and on this account, moved by royal and gracious tenderness, in the following year, 15()3, he sent at his own expense two armed ships in search of them; but it could never be discovered where or in what manner either the one or the other was lost, on which account this province of Terra Verde, where it was supposed the two brothers perished, was called the Land of the Cortereals." * The description of the inhabitants, as given by this contemporary chronicler, contains a few additional particulars to those mentioned by Pasquiligi. "The people of the country," says he, "are very barbarous and uncivilized, almost equally so with the natives of Santa Cruz, except that they are white, and so tanned by the cold that the white colour is lost as they grow older, and they become blackish. They are of the middle size, very lightly made, and great archers. Instead of javelins, they employ sticks burnt in the end, which they use as missiles to as good purpose as if they were pointed with fine steel. They clothe themselves in the skins of beasts, of which there are great plenty in the country. They live in caverns of rocks, and in houses shaped like nests (choupanas).

* Damiano Goes, Chronica del Rey Dom. Manuel, part i. c. 66. 
They have no laws, believe much in auguries, live in matrimony, and are very jealous of their wives, -in which things they much resemble the Laplanders, who also inhabit a northern latitude under $70^{\circ}$ to $85^{\circ}$, subject to the kings of Norway and Sweden." **

Upon these voyages of the Cortereals the Portuguese attempted to establish a claim to the discovery of Newfoundland and the adjacent coasts of North America, though there is ample historical evidence that both had been visited by the two Cabots three years prior to the departure of Cortereal from Lisbon. Maps appear to have been forged to support this unfair assumption; and in a volume published by Madrignanon at Milan in 1508, which represents itself to be a translation of the Italian work entitled "Paesi Nuovamente Ritrovati," the origrinal letter of Pasquiligi, describing the arrival of Gaspar Cortereal, is disgracefully garbled and corrupted,-for the purpose, as it would seem, of keeping the prior discoveries of the Cabots in the background, and advancing a fabricated claim for the Portuguese. $f$ It is unfortunate that this disingenuous process of poisoning the sources of historic truth has succeeded, and that many authors, not aware of its apocryphal character, which has been acutely exposed by the biographer of Cabot, have given a pernicious currency to the fable of Madrignanon.

About fourteen years after his return from the voyage of 1498, we have seen that Sebastian Cabot was induced to enter the service of Spain ; but, though highly esteemed for his eminent abilities, appointed one of the Council of the Indies by Ferdinand, and nominated to the command of an expedition to the north in search of a north-west passage, he appears to have been baffled and thwarted in his plans by the jealousy of the Spaniards, and was at last compelled to abandon them on the death of Ferdinand. He then returned to England; and, indefatigable in the prosecution of that great object which formed the prominent pursuit of his life, induced Henry VIII. to fit out a small squadron for the discovery of the north-west passage to India. Unfortunately, however, for the success of the voyage, Sir Thomas Pert, at this time vice-adıniral of England, was intrusted with the

* Damiano Goes, Chronica del Rey Dom. Manuel, part i. c. 66, p. 87.

$\uparrow$ Memoir of Sebastian Cabot, p. 251, 252. 
supreme command, whose want of courage and resolution was the cause of its ultimate failure. The object of Cabot was to proceed by Iceland towards the American coast, which he had already explored as far as $56^{\circ}$, according to Ramusio, or, if we follow Gomara, $58^{\circ}$ north. This would lead him, to use the expression of Thorne, ${ }^{*}$ by the back of Newfoundland, and from this point, pursuing his voyage far. ther to the northward, he expected to find a passage to the kingdom of Cathay. The ships accordingly set sail, and on the 11th of June they had reached the $672^{\circ}$ of northern latitude. They here found the sea open, and Cabot entertained a confident hope of sailing through a bay or "fret," which they had then entered, to the shores of the Eastern Cathay, when a mutiny of the mariners, and the faintheartedness of Sir Thomas Pert, compelled him, much against his inclination, to desist from the further prosecution of the voyage, and return home.t From the high latitude

* Letter of Robert Thorne,-Hakluyt, edition of 1559, p. 250.- "And if they will take their course, after they be past the Pole, towards the occident, they shall goe in the back side of the Newfoundlanil, which of late was discovered by your grace's subjects, until they come to the back side and south seas of the Indies Occidental: and so, continuing their voyage, they may return thorow the Straight of Magellan to this country, and so they compass also the world by that way; and if they goe this third way, and after they be past the Fole, goe right toward the Pole Antarticke, and then decline towards the lands and islands situated between the tropicks and under the equinoctial, without douot they shall find there the richest lands and islands of the world, of gold, precious stones, balmis, spices, and other thinges that we here esteem most, which come out of strange countries, and may return the same way." See also Gomara, as quoted in the Memoir of Sebastian Cabot, p. 21 .

I It is evidently to this third voyage that the passage in Ramusio, vol. iii. p. 4. of the "Diseorso sopra il terzo volume," applies. Memoir of Cabot, p. 117. It is valuable, as this author, though he appears by mistake to have put the name of Henry VII. for that of Henry VIII., quotes in it a letter which many years before he had received from Sebastian Cabot himself. He (Ramusio) in speaking of the discoveries subsequently made hy Verazzano, and of the country of New-France, remarks, that of this land it is not certain as yet whether it is joined to the continent of Florida and New-Spain, or whether it is separated into islands, and may thus admit of a passage to the kingdom of Cathay. "Come," he proceeds, "come mi fü scritto gia molti anni sono, dal Signor Sebastian Gabotto nostro Viritiano huomo di grande esperienza et raro nell' arte del navigare, e nella scienza di cosmografia : il quale avea navicato disopra di questa terra della Nuova-Francia a spese del Re Henrico VII. d'Inghilterria e me diciva, come essendo egli andato lungamente alla volto de ponente e quarta di Maestro dictro queste Isole poste lungo la delta terro 
reached by this enterprising seaman, as well as from the expressions employed by Sir Humphrey Gilbert in speaking of the veyage, it appears certain that Cabot had entered tho great bay afterward explored by Hudson, and since known by his name." It is an extraordinary fact, therefore, but it rests upon evidence which it would be difficult to controvert, that ninety years before the first voyage of Hudson he had been anticipated in his principal discovery by an early navigator, to whose merits the world have done little justice.

While the Portuguese, the Spaniards, and the English had early entered upon the career of discovery, the French, a people undoubtedly of the highest genius and enterprise, evinced an unaccountable inactivity upon this great subject, and appeared to view with indifference the brilliant successes of other nations. At length Francis I., a monarch who was deeply smit with the love of glory, caught the enthusiasm for maritime discovery, and, eager to cope upon equal terms with his great rival Charles V., fitted out a. squadron of four ships, the command of which he intrusted to Giovanni Verazzano, a Florentine navigator of great skill and celebrity. The destination of the armament, however, appears to have embraced the purposes of plunder as well as of discovery; and in a cruise three of his vessels were so much damaged in a storm, that they were compelled, for the purpose of refitting, to run into a port in Brittany, from which, impatient of the delay, the admiral, in a single vessel named the Dauphin, set sail with a determination to prosecute discoveries. He first steered his course for Madeira,

fini a gradi sessanta sette e mezzo sotto il nostro polo a xi. di Guigno e tro. vandosi il mare aperto e senza impedimento alcuno, pensava fermamente per quella via di poter passare alla volta del Cataio Orientale, e l'avrebbe fatto, se la malignita del padrone e de marineri sollevati non l'havessero fatto tornare a dietro." This discourse is dated 20th June, 1553.

* Hakluyt, vol. iii. p. 16. It must be recollected that Sir Humphrey Gilbert had the advantage of having examined the charts of Sebastian Cabot, which, he tells us, were then to be seen in the queen's privy gallery at Whitehall. It has also been acutely remarked by a late writer (Mernoir of Cabot, p. 29), that Ortelius, who died nine years before Hudson undertook his first voyage, in the map of America, published in his great geographical work, the "Theatrum Orbis Terrarum," has laid down the form of Hudson's Bay with singular precision. Now we know by the list of authorities cited by Ortelius, that he was in possession of a map of the world by Sebastian Cabot. The source, therefore, from which he derived his information is evident. 
and thence sailed in a westerly direction for twenty-five days, making in that time 500 leagues. A storm now attacked him, in which his little ressel had nearly perished, but he at last weathered the gale, and proceeding on wards for 400 leagues, arrived upon a coast that, according to his own account, had never before been visited.* It is probable that this shore belonged either to North or South Carolina ; $\uparrow$ and the appearance of many large fires on the beach convinced him that the country was inhabited. Verazzano, however, in vain sought for a port; and after exploring the coast both to the south and north without success, he was compelled to anchor in the open sea, after which he sent his boat on shore to open an intercourse with the natives. This he effected not without some difficulty; for as soon as the French landed the savages fled in great trepidation; yet they soon after stole back, exhibiting signs of much wonder and curiosity. At last being convinced that they had nothing to fear, they completely recovered their confidence, and not only brought provisions to the French, but assisted them in drawing their boat on shore, and carefully and minutely scrutinized every thing belonging to the vessels and the crew. They admired the white skin of the strangers, handled their dress, and exhibited the utmost astonishment and delight. They themselves were a handsome race of people, their eyes dark and large, their expression bold, open, and cheerful; their chests were broad, and they combined middle stature and symmetry of limbs with great nimbleness and swiftness of foot. Their colour was tawny, not unlike the Saracens, and they wore their hair, which was black and thick, tied behind their head in a little tail, and sometimes ornamented with a garland of birds' feathers. Their bodies were not disfigured or tattooed in any way, and they walked about perfectly naked, except that they wore short aprons of furs fastened round their middle by a girdle of woven grass. In the immediate vicinity of the coast the country was sandy, rising into gentle undulations; as they proceeded it became more elevated, and was covered by noble woods, consisting, not of the usual forest-trees, but

* Ramusio, Viaggi, vol. iii. p. 420. "Dovi scopsimmo una terra nuova, mon piu da gl'antichi ne da moderni vista,"

t "Sta questa terra in gradi $34^{\circ}$."-Ramusio, vol, iii. p. 420. 
of the palm, laurel, cypress, and others then unknown in Europe, which grew to a great height, and diffused a delicious perfume that was discerned far out at sea. "The land also," says Verazzano in his letter to Francis I., " is full of many animals, as stags, deer, and hares, which were seen sporting in the forests, and frequenting the banks of pleasant lakes and rivers; nor were there wanting great plenty and variety of birds of game, fitted to afford delightful recreation for the sportsman. The sky was clear, the air wholesome and temperate, the prevalent wind blowing from the west, and the sea calm and placid. In short, a country more full of amenity could not well be imagined." ** An excellent author and navigator thinks it probable that the spot where Verazzano first landed was on the coast of Georgia, near the present town of Savannah.t

From this he proceeded along the shore, which turned to the eastward and appeared thickly inhabited, but so low and open that landing in such a surf was impossible. In this perplexity a young sailor undertook to swim to land and accost the natives; but when he saw the crowds which thronged the beach he repented of his purpose, and although within a few yards of the landing-place, his courage failed, and he attempted to turn back. At this moment the water only reached his waist ; hut, overcome with terror and exhaustion, he had scarcely strength to cast his presents and trinkets upon the beach, when a high wave cast him stupified and senseless upon the shore. The savages ran immediately to his assistance, and carried him to a little distance from the sea, where it was some time before he recovered his recollection; and great was his terror when he found himself entirely in their power. Stretching his hands towards the ship, he uttered a piercing shriek, to which his friends of the New World replied by raising a loud yell, intended, as he afterward found, to encourage him. But, if this was sufficiently alarming, their further proceedings proved still more formidable. They carried him to the foot of a hill, turned his face towards the sun, kindled a large fire, and stripped him naked. No doubt was now left in the mind of the unhappy man that they were about to offer him 
as a sacrifice to tne sun; and his companions on board, who watched the progress of the adventure, unable, from the violence of the sea, to lend him assistance, were of the same opinion. They thought, to use Verazzano's own words, that the natives were going to roast and eat him.* But their fears were soon turned into gratitude and astonishment; for they only dried his clothes, warmed him, and showed him every mark of kindness, caressing and patting his white skin; and on observing that he still trembled and looked suspicious, they assisted him to dress, conducted him to the beach, tenderly embraced him, and pointing to the vessel, removed to a little distance to show that he was at liberty to return to his friends. This he did by swimming to the ship's br, ', which had been put out to receive him, followed by line kind gestures of the savages, who gazed after him till they saw him safe among his friends. The spot where Verazzano found this amiable people is conjectured by Forster to have been somewhere between NewJersey and Staten Island.

From this the Florentine sailed onward, observing the coast trending to the northward, and after a run of fifty loagues came to anchor off a delightful country covered with the finest forests. The trees, although equally luxuriant, did not emit the same perfume as those before seen; but the region was rich, covered with grass, and thickly peopled, although the natives appeared more timid than the last, and avoided all intercourse. The sailors, however, discovered and seized a family who had concealed themselves in the underwood, consisting of an old woman, a young girl of a tall and handsome figure, and six children. The two younger of the little ones were squatted on the shoulders of the old woman, and another child hung behind her back, while the girl was similarly loaded. On being approached both the females shrieked loudly; but, having succeeded in pacifying them, the sailors understood by their signs that all the men had escaped to the woods on the appearance of the ships. Much persuasion was now used to induce them to go on board; but although the elderly lady showed symptoms of acquiescence, and eagerly ate the food which was offered her, no entreaties could soften the obstinacy and rage of the

* Ramusio, vol. iii. p. 42 t. 
younger. She uttered piercing cries, cast the meat indignantly on the ground, and rendered the task of dragging her through the thick woods so tedious and distressing, that they were obliged to desist and leave her, only carrying with them a little boy, who could make no resistance.* The people of this country possessed fairer complexions than those whom they had just left, and were clad with large leaves sewed together with threads of wild hemp. Their common food was pulse, but they subsisted also by fishing, and were very expert in catching birds with gins. Their bows were made of hard wood, their arrows of canes headed with fish-bone, and their boats constructed of one large tree hollowed by fire, for they appeared to have no instruments of iron or other metal. Wild vines crept up the trunks of the trees, hanging in rich festoons from the branches, and the banks and meadows were covered with roses, lilies, violets, and many sorts of herbs different from those of Europe, yielding a fresh and delightful fragrance.

Verazzano now proceeded one hundred leagues farther to a sheltered and beautiful bay surrounded by gently rising hills, and discovered a large river, which from its depth seemed navigable to a considerable distance. Fearful, however, of any accident, they ascended it in hoats; and the voyage conducted them through a country so full of sweetness and attraction that they left it with much regret. $†$ Prosecuting their discoveries fifty leagues eastward, they reached another island of a triangular shape, covered with rich wood, and rising into gentle hills, which reminded them of Rhodes both in its form and general aspect. A contrary wind, however, rendered it impossible to land, and pursuing their course about fifteen leagues farther along the coast, they found a port where there was an excellent anchorage. Here they were soon visited by the natives, who came in a squadron of twenty boats, and at first cautiously kept at the distance of fifty paces. Observing, however, the friendly gestures of the strangers, they ventured nearer, and when the French threw them bells, mirrors, and other trinkets, they raised a loud and simultaneous shout expressive of joy and security, no longer hesitating to row their boats to the ship's side and come aboard. They are described by Verazzano 
in his account of the voyage sent to Francis I., as the finest and handsomest race, and the most civilized in their manners, of any he had yet met in America. Their colour was fairer than that of the more southern people, and in the symmetry of their forms, and the simplicity and gracefulness of their attitudes, they almost vied with the antique. They soon became exceedingly friendly and intimate, and conducted the French into the interior of the country, which they found variegated with wood, and more delightful than can be easily described. Adapted for every sort of cultivation, whether of corn, vines, or olives, it was interspersed with plains of twenty-five or thirty leagues in length, open and unencumbered with trees, and of such fertility, that whatever fruit might be sown was certain to produce a rich and abundant return. They afterward entered the woods, which were of great size, and so thick that a large army might have been concealed in them. The trees consisted of oaks and cypresses, besides other species unknown to Europe. They found also apples, parsley, plums, and filberts, and many other kinds of fruit different from those of Italy. They saw likewise many animals, such as harts, roes, wolves, and stags, which the natives caught with snares, and destroyed with bows and arrows, their principal weapons of offence. The arrows were made with great neatness, and at the point instead of iron they inserted flints, jaspers, hard marble, and other kinds of cut stones. These they also made use of in felling trees, and in excavating their boats, which with great skill were made of a single trunk, yet large enough to hold ten or twelve men commodiously. Their oars were short and broad at the extrenity, which they plied in the sea without any accident happening, trusting solely to their strength of arm and skilful management, and seeming able to go at almost any rate they pleased. Their houses were constructed in a circular shape, ten or twelve paces in circuit, built of boards, and separated from each other without any attention paid to architectural arrangement, covered with tiles made of clay, of excellent workmanship, and effectually protected from the wind and rain.* On one subject alone they showed suspicion, being extremely jealous of the least intercourse between tho 
French and their women. These they would on no persuasion allow to enter the ship ; and on one occasion, while the king came on board, and spent some hours in curiously examining every part of the vessel, his royal consort was left with her female attendants in a boat at some distance, strictly watched and guarded.*

The French now bade adieu to this kind people, and pursued their discoveries for one hundred and fifty leagues, exploring a coast which extended first towards the east and afterward to the north. The country still presented an agreeable and inviting aspect, although the climate became colder, and the regions along which they passed more hilly. A progress of other fifty leagues brought them to a more mountainous district than any yet seen, covered with dark and dense forests, and possessed by a people whose habits and temper seemed to partake of the severer nature of their country. On attempting to open an intercourse, Verazzano found them as fierce and sullen as those with whom he had lately dealt were agreeable and generous. Twenty-five of the crew who landed were received with a shower of arrows; and although the exhibition of articles of barter overcame their scruples, and tempted them to agree to an interchange of commodities, the manner in which this was effected evinced a striking mixture of avidity and suspicion. They came down to the beach, choosing the spot where the surf was breaking most violently, and insisted that the French boat should remain on the other side; a rope was then passed from it to the shore, and the different articles were swung along it. Strings of beads, toys, or mirrors they utterly despised; but eagerly received knives, fishinghooks, swords, saws, or any thing in the shape of cuttingmetal to be used in war or in the chase, though such was their savage temper, that during the process of exchange they expressed their aversion to the strangers hy uncouth gestures of contempt and derision. It seems probable that the country now for the first time visited by Europeans was the present state of Maine; as we are told by Verazzano, that a further run of fifty leagues along the

* This country, according to Verazzano, was situated in $41_{3}^{20}$ of latitude (Ramusio, vol. iii. p. 422), which, if correct, would point it out 8 the present flourishing state of Massachusetts. 
coast brought him to a cluster of thirty islands separated $\mathrm{by}$ narrow channels, - a description which points out, in precise terms, the Bay of Penobscot.*

From this point he pursued his indefatigable course for one hundred and fifty leagues farther, till he reached the land already discovered, as he says, by the Britons in the latitude of $50^{\circ}$, which is evidently Newfoundland. Here his provisions began to fail, and thinking it prudent to sail for France, he reached home in safety in the month of July, 1524.

Verazzano had thus completed the survey of a line of coast extending for seven hundred leagues, and embracing the whole of the United States, along with a large portion of British America. It was undoubtedly an enterprise of great magnitude and splendour, and deserves to be carefully recorded, not only as comprehending one of the widest ranges of early discovery, but as making us for the first time acquainted with that noble country whose history is so important, and whose destinies, even after a progress unrivalled in rapidity, appear at this moment only in their infancy. The Florentine gave to the whole region which he had discovered the name of New-France; he then laid before the king a plan for completing his survey of the coast, penetrating into the interior, and establishing a colony ; and he appears to have met with encouragenent from Francis I., who embrared his proposals for colonization. From this moment, however, his history is involved in obscurity. Hakluyt affirms that he performed three voyages to North America, and gave a map of the coast to Henry VIII. The biographer of Cabot asserts, that he was the "Piedmontes? pilot" who was slain on the coast of America in 1527, + no aware that Verazzano was a Florentine and alive in 1537 , and Ramusio could not ascertain the particulars of his last expedition, or even discover in what year it took place. All that is certainly known is, that it proved fatal to this great navigator. Having landed incautiously upon the American coast, he and his party were surrounded and cut to pieces

* Miurray's North America, vol. i. p. *9. The veracity of the Florentine navigator, in his description of the ferocious habits of the natives, is strikingly corroborated by the determined and rancorous hostility evinced afterwari by the Indians of this district in opposing every attempt at settlement.

† Memoir of Cabot, p. 278. 
by the savages; after which they barbarously devoured them in the sight of their companions.*

The death of Verazzano appears to have thrown a damp over the further prosecution of discovery by the court of France; but at length, after an interval of ten years, Jacques Cartier, an enterprising and able mariner of St. Malo, was chosen by the Sieur de Melleraye, vice-admiral of France, to conduct a voyage to Newfoundland, which, since its discovery by Cabot, had been seldom visited, and was imperfectly known. Cartier departed from St. Malo on the 20th of April, 1534, with two ships, each of 60 tons burden, and laving on board a well-appointed crew of sixty-one men. $\dagger$ The voyage appears to have been limited to a survey of the northern coast of Newfoundland, of which he gives a minute description, dwelling particularly on the zoological features of the country. He found the land in most parts extremely wild and barren, "insomuch that he did not see a cartload of good earth; and the inhabitants were of stout make, but wild and unruly." They wore their hair tied on the top like a bunch of hay, fixed with a wooden bodkin, and ornamented with hirds' feathers. Like their companions whom Cabot had described, they were clothed

* Such is the account of Ramusio in his Discourse unon Nerv-France, vol. iii. p. 417. But Carienas, in a work entitled "Ensajo Cronologico para la Historia de la Floridas" (p. 8), has committed an error similar to that of the writer of Cabot's life. He helieves that Verazzano was the same as Juan the Florentine, a pirate in the service of France, who was taken by the Spaniards in 1524, and hanged. The evidence which overturns the theories of both these authors is to be found in a letter of Annibal Caro, quoted by Tiraboschi, Storia della Letteratura Ital., vol., vii. part i. n. 261,262 , from which it appears that Verazzano was alive in 1537. Lettere Familiari del. Comm. Annibal Caro, vol. i. p. 11. In his great work, Tirahoschi has collected all that is known regarding the life of this eminent discoverer; but this all is little or nothing. He was born ahout the year 1485; his father was Pierandrea Verazzano, a noble Florentine, his mother Fiametta Capelli. Of his youth, and for what reasons he entered into the service of Francis I., nothing is known. The only published work of Verazzano is the narrative in Ramusio, addressed to Francis I., written with much simplicity and elegance. But in the Strozzi Library at Florence is preserved a manuscript, in which he is said to give, with great minuteness, a description of all the countries which he had visited during his voyage, and from which, says Tirabeschi, we derive the intelligence that he had formed the design of attempting a passage through these seas to the East Indies. It is much to be desired that some Italian seholar would favour the world with the publication of this MS. of Verazzano.

† Ramusio, vol. iii. p. 435. 
in beasts' skins, and ormamented their bodies by painting them with roan-colours. They paddled about in boats made of the bark of birch-trees, in which they carried on a constant trade of fishing, and caught great numbers of seals. After having almost circumnavigated New foundland, Cartier stood in towards the continent, and anchored in a bay which, from the extreme heat, was denominated Baye du Chaleur. The description of the inhabitants of this spot is striking and interesting. "Taking our way," says he, "along the coast, we came in sight of the savages, who stood on the borders of a lake in the low grounds, where they had lighted their fires, which raised a great smoke. We went towards them, and found that an arm of the sea ran into the lake, into which we pushed with our boats. Upon this the savages approached in one of their little barks, bringing along with them pieces of roasted seals, which they placed upon wooden boards, and afterward retired, making signs that this was intended as a present for us. We immediately put two men ashore, with hatchets, knives, garlands for the head, and such-like wares. On seeing these articles they appeared much delighted, and crowded to the bank where we were, paddling their barks, and bringing skins and other articles, which they meant to exchange for our merchandise. Their number, including men, women, and children, was upwards of three hundred. Some of the women, who would not venture nearer, stood up to the knees in water, singing and dancing. Others, who had passed over, came to us with great familiarity, rubbing our arms with their hands, which they afterward lifted up to heaven, singing all the while and making signs of joy; such at last was their friendliness and security, that they bartered away every thing they had, and stood beside us quite naked; for they scrupled not to give us all that was on them, and indeed their whole wardrobe was not much to speak of. It was evident that this people might be without difficulty converted to our faith. They migrate from place to place, and subsist themselves by fishing. Their country is warmer than Spain, and as beautiful as can be imagined,level, and covered even in the smallest spots with trees, and this although the soil is sandy. It is full also of wild corn, which hath an ear similar to rye. We saw many beautiful meadows full of rich grass, and lalses where there were 
plenty of salmon. The savages called a hatchet cocki, and a knife bacon."* All the navigators who had hitherto visited Newfoundland, on reaching its northernmost point, appear to have sailed across the Straits of Belleisle to Cape Charles, upon the coast of Labrador; but the course of Cartier led him through the straits into the great Gulf of St. Lawrence, now for the first time visited by any European. His predecessor, Verazzano, after reaching the shore of the Bay of Fundy, had probably sailed along the coast of Nova Scotia until he reached Cape Breton. Cartier, on the contrary, saw before him a wide and extensive field of discovery to the west, which he pursued for some time, directing his course along the coast of the Bay of St. Lawrence; but, as the season was far advanced, and the weather became precarious, he determined to reserve a more complete examination of this unknown country for a second voyage, and returned safely to France, coming to anchor in the port of St. Malo upon the 5th of September, 1534.†

Having been received with favour and distinction, Cartier, after a short interval, embarked upon a second voyage. His squadron consisted of three ships,--the Great ?Aermina, of which Cartier himself was master, being a vessel of about 120 tons; the Little Hermina of 60 tons, and the Hermirillon of 40 tons burden. The crews solemnly prepared themselves for their voyage by confession and the reception of the sacrament; after which they entered in a body into the choir of the cathedral, and stood before the bishop, who was clothed in his canonicals, and devoutly gave them his benediction. Having fulfilled these rites, the fleet weighed anchor on the 15th of May, 1535, and the admiral steered direct for Newfoundland. His ships, however, were soon after separated in a storm, and did not again join company till the 26th of June; after which they proceeded to explore the large gulf which he had already entered. "It was," to use the words of the navigator himself, "a very fair gulf, full of islands, passages, and entrances to what winds soever you pleased to bend, having a great island like a cape of land stretching somewhat farther forth than the others." This island is evidently that named by the English Anticosti, being merely a

* Ramusio, vol. iii. p. 438. 
corruption of Natiscotec, the appellation at this day given it by the natives. To the channel between it and the opposite coast of Labrador Cartier gave the name of St. Lawrence, which has since been extended to the whole gulf.

On reaching the eastern point of the island of Anticost1, the French, who had along with them two of the natives of the country, whom they had induced in their former voyage to accompany them to France, requested their advice as to their farther progress. The savages stated, that the gulf in which they now lay gradually contracted its dimensions till it terminated in the mouth of a mighty river named Hochelaga, flowing from a vast distance in the interior of a great continent. 'That two days' sail above Anticosti would bring them to the kingdom of Saguenay, beyond which, along the bank of the same river, was a populous territory, situated at its highest known point, where the stream was only navigable by small boats. Having received this information, Curtier sailed onwards, exploring both sides of the river, and opening a communication with the inhabitants by means of the natives whom he carried along with him. The good effects of this arrangement were soon seen; for at first they fled in great alarm upon the approach of any of the ships' crews; but on hearing the interpreters cry out that they were Taignoagny and Domagaia,-names which seemed to inspire immediate ideas of friendliness and confidence,- - they suddenly turned back; after which they began to dance and rejoice, running away with great speed, and soon returning with eels, fishes, grain, and muskmelons, which they cast into the boats, with gestures expressive of much kindness and courtesy.* This soon led to a more intimate and interesting intercourse; and on the following day the lord of the country, who was named Donnaconna, made a formal visit to the admiral's ship, accompanied by twelve boats, in which were a great multitude of his subjects. On approaching the vessel he ordered ten of these boats to ship their paddles and remain stationary, while he himself, with the other two boats, and attended by a suite of sixteen of his subjects, advanced over-against the smallest of the French ships, and standing up, commenced a long oration, throwing his body into a variety of

- Ramusio, vol. iii. p. 441. 
strange and uncouth postures, which were afterward discovered to be signs indicating gladness and security. Donnaconna now came aboard the admiral's ship, and an enthusiastic interview took place between him and the two savages who had been in France.* They recounted with much gesticulation the extraordinary things which they had seen in that country, dwelling on the kind entertainment they had experienced, and after many expressive looks of wonder and gratitude, the king entreated the admiral to stretch out his arm, which he kissed with devotion, laying it fondly upon his neck, and showing, by gestures which could not be mistaken, that he wished to make much of him. Cartier, anxious to evince an equal confidence, entered Donnaconna's boat, carrying with him a collation of bread and wine, with which the monarch was much pleased, and the French, returning to their ships, ascended the river ten leagues, till they arrived at a village where this friendly potentate usually resided, and which was named Stadacona. "It was," according to the original account of Cartier, "as goodly a plot of ground as possibly might be seen, very fruitful, and covered with noble trees similar to those of France, such as oaks, elms, ashes, walnut-trees, mapletrees, citrons, vines, and white thorns which brought forth fruit like damsons; and beneath these woods grew as good hemp as any in France, without its being either planted or cultivated by man's labour." $\dagger$

From this time the intercourse between the French and Donnaconna continued with every expression of friendliness; but on hearing that the admiral had determined to go to Hochelaga, a sudden jealousy appeared to seize him, lest he and his people should be deprived of the advantages of an uninterrupted communication with the white strangers, and every possible device was put in execution to deter them from their purpose. One of these stratageins was so ludicrous that we may be permitted to give Cartier's account of it in an abridgment of the quaint translation of Hakluyt: "The next day, being the 18th of September, these men still endeavoured to seek all means possible to hinder us from going to Hochelaga, and for this purpose

* Ramusio, vol. iii. p. 443. Seconda Relatione di Jacques Cartier

† Hakluyt, vol. iii. p. 216. 
devised a pretty guile. They went and dressed three men like devils, being wrapped in dogs' skins, white and black, with their faces besmeared as black as a coal, and horns upon their heads more than a yard long." These figures they caused to be secretly put into one of the boats, which they concealed within a winding of the wooded bay, waiting patiently for the tide. When the proper moment had arrived, a multitude of the boats, crowded with natives and conducted by Taignaogny, suddenly emerged from the creek; on a signal given, the boat in which were the counterfeit devils came rushing out of its concealment, and the middlemost devil, standing up, made a long oration, addressed to the French ships, of which of course every syllable was unintelligible. "Then," to resume the words of Hakluyt, "did King Donnaconna with all his people pursue them, and lay hold on the boat and devils, who, so soon as the men were come to them, fell prostrate, as if they had been dead, upon which they were taken up and carried into the wood, being but a stonecast off, at which time every one of the savages withdrew himself into the wood, and when there began to make a long discourse, so loud that it was easy for the French to hear them even in their ships. When this oration or debate, which lasted for half an hour, was ended, Cartier and his crew espied Taignaggny and Domagaia coming towards them, holding their hands joined together, carrying their hats under their upper garment, showing a great admiration, and looking up to heaven. Upon this the captain, hearing them, and seeing their gestures and ceremonies, asked them what they ailed, and what was happened or chanced anew ? to which they answered that there were very ill tidings befallen, saying in their broken French, 'Nenni est il bon,' that is to say, it was not good. Our captain asked them again what it was, and then they answered that their god Cudraigny had spoken in Hochelaga, and that he had sent those three devils to show unto them that there was so much ice and snow in that country that whosoever went there should die; which words when the French heard they laughed and mocked them, saying that their god Cudraigny was but a fool and a noddie, for he knew not what he said or did. Thoy bade them also cairy their compliments to his mes. 
sengers, and inform them that the God whom they served would defend them from all cold if they would only believe in him."**

Having thus failed in the object intended to be gained by this extraordinary masquerade, the savages offered no further opposition, and the French proceeded in their pinnace and two boats up the river St. Lawrence towards Hochelaga. They found the country on both sides extremely rich and beautifully varied, covered with fine wood, and abounding in vines, though the grapes, from want of cultivation, were neither so large nor so sweet as those of France. The prevalent trees were the sarne as in Europe, -oaks, elms, walnut, cedar, fir, ash, box, and willow ; and the natives on each side of the river, who appeared to exercise principally the trade of fishermen, entered into an intercourse with the strangers as readily and kindly as if they had been their own countrymen. One of the lords of the country did not scruple after a short acquaintance to make a present to Cartier of two of his children ; one of whom, a little girl of seven or eight years old, he carried away with him, while he returned the other, a boy, who was considered too young to travel. They saw great variety of birds, almost all of which were the same as those of Europe. Cranes, swans, geese, ducks, pheasants, partridges, thrushes, blackbirds, turtles, finches, redbreasts, nightingales, and sparrows of divers kinds were observed, besides many other birds.

By this time the river had become narrow, and in some places dangerous in its navigation, owing to the rapids ; and the French, who had still three days' sailing before them, left their pinnace and took to their boats, in which, after a prosperous passage, they reached the city of Hochelaga. It consisted of about fifty houses, built in the midst of large and fair corn-fields near a great mountain, which the French called Mont Royale, corrupted by time into Montreal, which name the place still retains; while the original American designation of Hochelaga has been long since forgotten. The city, according to Cartier's description, was round, compassed about with timber, and with three courses of ramparts, one within another, framed like a sharp spire, but laid

* Hakluyt, vol. iii. p. 218; and Ramusio, vol, iii. p. 444. 
across above. The enclosure which surrounded the town was in height about two roods, having but one gate, which was shut with piles, stakes, and bars. Over it, and also in various parts of the wall, were places to run along, and ladders to get up, with magazines or heaps of stones for its defence. The houses were entirely of wood, with roofs of bark very artificially joined together. Each house had a court in the midst of it, and consisted of many rooms, while the family lighted their fire in the centre of the court, and during the day all lived in common; at night the husbands, wives, and children retired to their several chambers. At the top of the house were garners where they kent their corn, which was something like the millet of Brazil, and called by them carracony. They had also stores of pease and beans, with musk-melons and great cucumbers. Many large butts were observed in their houses, in which they preserved their dried fish; but this, as well as all their other victuals, they dressed and ate without salt. They slept upon beds of bark spread on the ground, with coverings of skins similar to those of which their clothes were made.*

The reception of the French by the inhabitants of Hochelaga was in a high degree friendly; and indeed such was the extent of their credulity and admiration, that they considered the strangers as possessed of miraculous power, and their commander a divine person. This was shown by their bringing their king, Agonhanna, an infirm paralytic about fifty years of age, to be touched, and, as they trusted, cured by the admiral, earnestly importuning him by expressive gestures to rub his arms and legs; after which the savage monarch took the wreath or crown which he wore upon his head and gave it to Cartier. Soon after this they brought with them all the diseased and aged folks whom they could collect, and besought him to heal them; on which occasion his conduct appears to have been that of a man of sincere piety. He neither arrogated to himself miraculous powers, nor did he altogether refuse their earnest request ; but read, from the Gospel of St. John, the passion of our Saviour, and praying that the Lord would be pleased to open the hearts of these forlorn pagans, and teach them to know the truth, he laid his hands upon them, and making the sign of the

* Ramusio, vol. iii. p. 445; and Hakluyt, vol. iii. p. 220, 221. 
cross, left the issue of their being healed or not in the hand of their Creator.*

On inquiring into their religious tenets, he found that they were buried in the deepest ignorance and superstition, unacquainted with the existence of the only true God, and substituting in his place a capricious and horrid being of their own imaginations, named Cudraigny. They affirmed that he often spoke to them, and told them what kind of weather they were to have; but, if angry, would punish them by throwing dust in their eyes. They had a strange and confused idea regarding the immortality of the soul, believing that after death they went to the stars, and descended like these bright sparks by degrees to the horizon, where they wandered about in delicious green fields, which were full of the most precious trees, and profusely sown with fruits and flowers. Cartier explained as well as he could the folly of such a creed, persuaded them that Cudraigny was no god but a devil, and at his departure promised to return again, and bring some good and holy men, who would instruct them in the knowledge of the true and only God, and baptize them in the name of his Son, with which they declared themselves well pleased.† "There groweth here," says Cartier, "a certain kind of herb, of which during the summer they collect a great quantity for winter consumption, esteeming it much, and only permitting men to use it in the following manner: It is first dried in the sun; after which they wear it about their necks, wrapped in a little skin made in the shape of a bag, along with a hollow piece of stone or of wood formed like a pipe; after this they bruise it into a powder, which is put into one of the ends of the said cornet or pipe, and laying a coal of fire upon it at the other end, they suck so long that they fill their bodies full of smoke till it comes out of their mouth and nostrils, even as out of the tunnel of a chimney. They say that this keeps them warm and in health, and never go without some of it about them." It is not impossible that the reader, perplexed by this laboriously minute description, may have failed to recognise in it the first acquaintance made by the French with the salubrious and far-famed plant of tobacco.

Not long after this the shins' crews were seized with a

* Ramusio, vol. iii. p. 448.

† lbid. p. 449.

t Whid 
loathsome and dreadful disease, caught, as they supposed, from the natives, which carried off twenty-five men, reducing the survivors to a state of pitiable weakness and suffering. The malady was then new to Europeans; but the symptoms detailed by Cartier, - swollen legs, extreme debility, putrified gums, and discoloration of the skin and blood,-leave no doubt that this "strange, unknown," and cruel pestilence was the scurvy, since so fatally familiar to the European mariner. Providentially, however, they discovered from the savages a cure in the decoction of the leaves and bark of a species of tree called in their language hannida, and since well known as the North American white pine. "This medicine," says Cartier, "worked so well, that if all the physicians of Montpellier and Louvain had been there, with all the drugs of Alexandria, they would not have done so much in one year as that tree did in six days."*

The French beran now to make preparations for their departure; but a dishonourable plot was first carried into execution, by which they succeeded in seizing Donnaconna, whose usefulness and liberality to them during their residence in Canada merited a more generous return. The monarch, however, with the exception of a slight personal restraint to prevent escape, was treated with kindness, and soon became reconciled to his journey to Europe, although his subjects, inconsolable for his loss, came nightly howling like wolves about the ships, till assured he was in safety. Along with Donnaconna were secured Taignaogny and Domagaia, who had already been in France; and, after a prosperous voyage, the French ships arrived at St. Malo on the 6th July, 1536. $\dagger$ It might have been expected that, after a discovery of such magnitude and importance, immediate measures would have been adopted to appropriate and colonize this fertile, populous, and extensive country. This seemed the more likely, as the arrival of Cartier and the introduction of the Indian king at court created an extraordinary sensation; yet notwithstanding the manifest advantages, both commercial and political, likely to result from a settlement in Canada, the weak and shallow prejudice which at this time prevailed in most of the nations of Europe, that no countries were valuable except such as produced gold and

* Ramusio vol, iii. p. 451.

t Ibid. p. 453. 
silver, threw a damp over the project, and for nearly four years the French monarch would listen to no proposals for the establishment of a colony.

Private adventure at length came forward to accomplish that which had been neglected by royal munificence, and the Sieur de Roberval, a nobleman of Picardy, requested permission of Francis I. to puisue the discovery, and attempt to form a settlement in the country. This the king readily granted; and as Roberval was opulent, the preparations were made on a great scale. He was created by Francis, on the 15th January, 1540, Lord of Norimbega, Lieutenant. general and Viceroy in Canada, Hochelaga, Saguenay, New foundland, Belleisle, Carpon, Labrador, the Great Bay, and Baccalaos,--empty and ridiculous titles, which, if merited by any one, ought to have been conferred upon Cartier. This eminent navigator, however, was only permitted to accept a subordinate command; and as Roberval, who wished to appear with splendour in his new dominions, was detained in fitting out two vessels which were his own property, Cartier was ordered to sail before him with the five ships already prepared. He accordingly did so; but Donnaconna, the Canadian king, had died in France, and the savages, justly incensed at the breach of faith by which they lost their sovereign, received the French with an altered countenance, devising conspiracies against them that soon led to acts of open hostility. The French now built for their defence, near the present site of Quebec, a fort, which they named Charlesbourg, being the first European settlement formed in that part of America. After a long interval Roberval arrived at Newfoundland; but a jealousy had broken out between him and Cartier, who took the first opportunity during the night to part from his principal, and return with his squadron to France. This of course gave a death-blow to the whole undertaking, for Roberval was nothing without Cartier; and, after some unsuccessful attempts to discover a passage to the East Indies, he abandoned the enterprise, and returned to his native country. The passion for adventure, however, again seized him in 1549, and he and his brother, one of the bravest men of his time, set sail on a voyage of discovery ; but they shared the fate of Verazzano and the Cortereals, being never again heard of. These disasters effect- 
ually checked the enthusiasm of France, while in England, the country to whose enterprise we have seen Europe indebted for her first acquaintance with the American continent, the spirit of maritime discovery appeared for some years almost totally extinct.

The plan of this historical disquisition now leads us to the examination of some remarkable enterprises of the Spaniards for the extension of their immense dominions in the New World, along the more northern coasts of America. The bold and comprehensive mind of Cortes, the con-

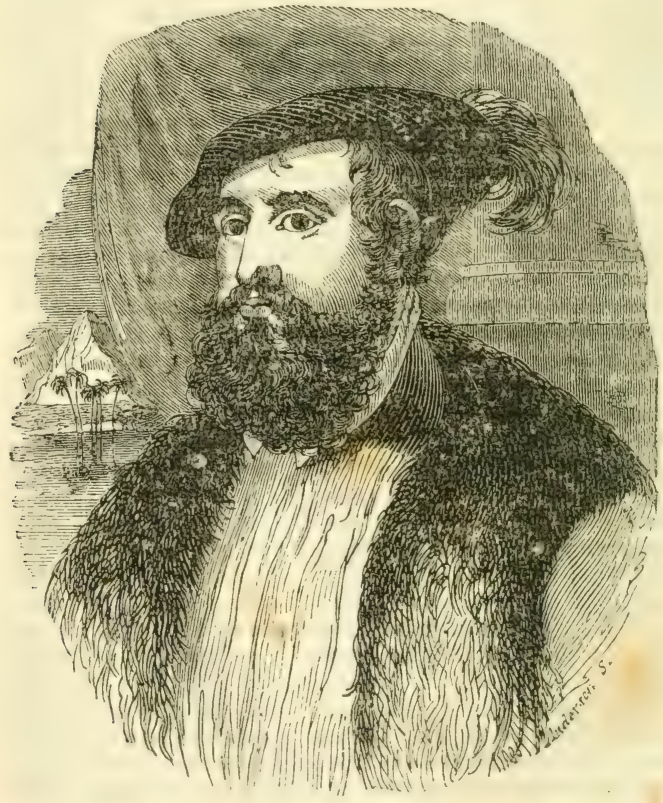


queror of Mexico, not content with the acquisition of that noble empire, formed the most extensive projects of discovery. Alarmeri at the attempts of the English to discover a northern passage to China and Cathay, he resolved to make a careful survey of the whole coast, extending from the river Panuco in Mexico to Florida, and thence northwards to the Baccalacs, for the purpose of ascertaining whether there might not exist in that quarter a communication with the South Sea. At the same time a squadron in the Pacific was to sail along the western coast of America, and by these simultaneous researches he trusted to find a strait aftording a far shorter and easier route to India and the Moluccas, and connecting together the vast dominions of the Spanish crown.* Charles V., to whom these proposals were presented, although willing to encourage every scheme for the extension of his power, ungenerously threw upon their author the whole expense of the undertaking; in consequence of which, the idea of the voyage for the discovery of a north-west passage was abandoned, and the magnificent designs for the conquest of many great and opulent kingdoms sank at last into the equipment of two brigantines on the coast of the South Sea, the command of which was intrusted to Diego de Hurtado. This expedition ended calimitously in a mutiny of one of the crews, who brought back their ship to Xalisco: the fate of Hurtado was still more unfortunate, for, although he continued his voyage, neither he nor any of his crew were ever more heard of. A second expedition, intrusted by Cortes to two Spanish captains, Grijalva and Mendoza, was scarcely more fortunate. The vessels were separated on the first night of their voyage, and never again joined company. Grijalva penetrated to an island which he denominated Santa Tome, supposed to have been situated near the northern point of California, after which he returned to Tehuantepec; while Mendoza, by his laughty and tyrannical temper, having rendered himself odious to his crew, was murdered by the pilot, Ximenes, who assumed the command. Afraid of returning to Mexico, the traitor sailed northward, and discovered the coast of California, where he was soon after

* Ramusio, vol. iii. p. 205. Memoir of Cabot, p. 263. 
attacked and slain, along with twenty of his crew, by the savage natives.*

The survivors, however, brought the vessel back to Chiametta, with the tempting report that the coast abounded in pearls. Cortes now set out himself, with a squadron of three ships; and, although his vessels were dreadfully shattered in a storm, pursued his voyage with his accustomed energy, till compelled to return by a summons from Mexico, where the breaking out of serious disturbances required his immediate presence. He intrusted, however, the prosecution of the voyage to Francisco de Ulloa; and this enterprising navigator, though at first obliged by want of provisions to return to Mexico, revictualled his ships, and again set sail. The pious solemnity with which these ancient mariners were accustomed to regard their proceedings is strikingly shown by the first sentence of his journal:"We embarked," says he, "in the haven of Acapulco, on the 8th of July, in the year of our Lord 1539, calling upon Almighty God to guide us with his holy hand to those places where he might be served, and his holy faith advanced; and we sailed from the said port by the coast of Sacatula and Motin, which is sweet and pleasant, owing to the abundance of trees that grow there, and the rivers which pass through these countries, for which we often thanked God, their Creator." + A voyage of twenty days brought the squadron to the harbour of Colima, from which they set out on the $23 \mathrm{~d}$ of August, and after encountering a tempest, in which their ships were severely shattered, they stood across the Gulf of California, and came to the mouth of the river St. Peter and St. Paul. On both sides of it were rich and extensive plains, covered with beautiful trees in full leaf; and farther within the land exceeding high mountains, clothed with wood, and affording a charming prospect; after which, in a course of fifteen leagues, they discovered two other rivers as great or greater than the Guadalquiver, the currents of which were so strong that they might be discerned three leagues off at sea.

Ulloa spent a year in examining the coasts and havens on each side of the Gulf of California. In some places the

* Hakluyt, vol. iii. p. 364 ; and Ramusio, Viaggi, vol. iii. p. 355.

t Ramusio, vol. iii. p. 339. Alurray's North America, vol. ii. p. 68 
Spaniards found the inhabitants of great stature, ${ }^{*}$ armed with bows and arrows, speaking a language totally distinct from any thing they had hitherto heard in America, and admirably dexterous in diving and swimming. On one occasion the crews, who had landed, were attacked with fierceness by two squadrons of Indians. These natives were as swift as wild goats, exceedingly strong and active, and leaped from rock to rock, assaulting the Spaniards with their arrows and javelins, which broke and pierced their armour, and inflicted grievous wounds. It is well known that this nation had introduced the savage practice of em ploying bloodhounds in their wars against the Mexicans, and Uiloa now used some of these ferocious animals. The Indians, however, discharred a shower of arrows against them, "by which," says Ülloa, "Berecillo, our mastiff, who should have assisted us, was grievously wounded ty three arrows, so that we could by no entreaty get him to leave us; the dog was struck in the first assault of the Indians, after he had behaved himself very gallantly, and greatly aided us, having set upon them and put eight or ten of them out of array. But the other mastiff's did us more harm than good, for when they attacked the indians, they shot at them with their bows, and we received hurt and trouble in defending them." +

From this unfriendly coast the Spanish discoverer proceeded to the Baya del Abad, about a hundred leagues distant from the point of California, where he found a more pacific people, who, though they exhibited great symptoms of suspicion, were prevailed upon to traffic, exchanging pearls and parrots' feathers for the beads and trinkets of the strangers. So little, however, were they to be trusted, that they afterward assaulted the ships' crews, compelling them to retreat to their vessels and pursue their voyage. They now discovered, in $28^{\circ}$ north latitude, a great island, which they denominated the Isle of Cedars, taking possession of it in the name of the Spanish monarch. It was inhabited by a fierce race of Indians, powerful and well made, and armed with bows and arrows, besides javelins, and long staves thicker than a man's wrist; with these they struck at the sailors, braving them with signs and rude gestures,

* Ramusio, vol. iii. p. 342.

† Hakluyt, vol. iii. p. 409 . Ramusio, vol. iii. p. 345. 
till at last it was found necessary to let loose the two mas. tiffs Berecillo and Achillo; upon which they suddenly took to flight, flying over the rough ground with the speed of wild horses.* Beyond this island the Spaniards attempted to continue their discoveries along the coast of California; but a tempest having driven them back and damaged their vessels, they determined to return to New-Spain. In their homeward voyage they were in danger from a new and extraordinary enemy ; for, when sailing in the main ocean at a rapid rate, above 500 whales, in separate shoals, came athwart them within one hour's space. Their monstrous size created great astonishment, some of them approaching so near the ship as to swim under the keel from one side to the other; "whereupon," says Francis Preciado, who wrote the relation of the voyage, "we were in great fear lest they should do us some hurt; but they could not, because the ship had a prosperous and good wind, and made much way, so that it received no harm although they touched and struck her." +

In this voyage, which for the first time made the world acquainted with the Gulf of California, or Sea of Cortes, Ulloa had not been able to spend sufficient time either in a survey of the coast or in establishing an intercourse with the natives. But not long after his return, Mendoza, the viceroy of New-Spain, despatched Friar Marco de Nica upon an expedition of discovery from Culeacan, at that time the most northerly Spanish settlement, to a province called Topira, situated in the mountains. The account brought back of the riches and extent of the country proved so tempting to the ambition of the Spaniards, that soon after Vasquez de Coronado, an officer of great courage and experience, was appointed by Mendoza to the command of a large force, for the reduction of the new territory ; while, to co-operate with this land expedition, a naval armament was fitted out, of which Ferdinand de Alarchon was appointed admiral, with orders to explore the Gulf of California. As far as conquest was intended, these mighty preparations conducted to no permanent results; but the voyage of Alarchon led to some important discoveries. After a survey of the lower part of the coast of the gulf,

* Ramusio, vol. iii. p. 351. Hakluyt, vol. iii. p. 419.

† Hakluyt, vol. iii. p. 424. 
he penetrated with much difficulty and hazard to the bot tom of the bay, where he found a mighty river, flowing with so furious a current that they could hardly sail against it.* This was evidently the noble river now known by the name of the Colorado, which has its rise in the great mountain-range near the sources of the Rio Bravo del Norte, and after a course of 900 miles falls into the head of the Gulf of California. Alarchon determined to explore it; and taking with him two boats, with twenty men and some small pieces of artillery, he ascended to an Indian village, the inhabitants of which, by violent and furious gestures, dissuaded the Spaniards from landing. The party of natives, at first small, soon increased to a body of 250 , drawn up in warlike fashion, with bows and arrows, and displayed banners. The Spanish admiral appeased them by signs, throwing his sword and target into the bottom of the boat, and placing his feet upon them. "They began," says he, in his letter to the viceroy Mendoza, " to make a great murmuring among themselves, when suddenly one came out from among them with a staff, upon which he had fixed some small shells, and entered into the water to give them to me. I took them, and made signs to him that he should approach. On his doing so, I embraced him, giving him in exchange some trinkets; and he returning to his fellows, they began to look upon them and to parley together; and within a while many of them cheerfully approached, to whom I made signs that they should lay down their banners and leave their weapons ; which they did immediately." Alarchon gives a minute description of the dress, weapons, and appearance of these Indians. They were decked after sundry fashions; the faces of some were covered with tattooed marks, extending lengthwise from the forehead to the chin, others had suly half the face thus ornamented; but all were besmeared with coal, and every one as it liked him best. Others carried vizards before them, which had the shape of faces. $t$ They wore on their heads a piece of deer-skin two spans broad, like a helmet, ornamented by various sorts of feathers stuck upon small sticks. Their weapons were bows and arrows, and two or three kinds ot

* Ramusio, Viaggi, vol. iii. p. 363.

4 Such is the translation of Hakluyt; but the passage in the origind is obscure. 
maces of wood hardened in the fire. Their features were handsome and regular, but disfigured by holes bored through the nostrils and in many parts of the ears, on which were hung pendants, shells, and bones. About their loins was a girdle of divers colours, with a large bunch of feathers in the middle, which hung down like a tail. They cut their hair short before, but allow it behind to grow down to their waist. Their bodies were tattooed with coals, and the women wore round their waist a great wreath of painted feathers, glued together, and hanging down both before and behind.*

Having procured by signs a pacific reception from this new people, Alarchon found to his mortification that they did not understand his interpreter; but, after a little intercourse, observing that they worshipped the sun, he unscrupulously intimated to them by significant gestures that he came from that luminary; "upon which they marvelled," says he, "and began to survey me from top to toe, and showed me more favour than they did before." Soon after this a man was found among them who could speak the language of the interpreter; and an intercourse of a very extraordinary nature took place, in which the honesty and simplicity of the Indians are strikingly contrasted with the false and unprincipled policy of the Spaniards. The passage is uncommonly graphic and interesting: "The Indian first desired to know what nation we were, and whence we came? Whether we came out of the water, or inhabited the earth, or had fallen from the heaven?" To this the admiral replied, that they were Christians, and came from far to see them, being sent by the sun, to which he pointed. "After this introduction, the Indian," continues Alarchon in his account of the voyage, "began again to ask me how the sun had sent me, seeing he went aloft in the sky and never stood still, and for these many years neither they nor their oldest men had ever seen such as we were, and the sun till that hour had never sent any other. I answered him, it was true the sun pursued his course aloft in the sky, and never stood still, but nevertheless they might perceive that at his setting and rising he came near the earth, where his dwelling was, and that they always saw him come out of one place; 
and he had created me in that land whence he came, in the same way that he had made many others whom he sent into other parts; and now he had desired me to visit this same river, and the people who dwelt near it, that I might speak with them, and become their friend, and give them such things as they needed, and charge them not to make war against each other. On this he required me to tell them the cause why the sun had not sent me sooner to pacify the wars which had continued a long time among them, and wherein many had been slain. I told him the reason was that I was then but a child. He next inquired why we brought only one interpreter with us who comprehended our language, and wherefore we understood not all uther men, seeing we were children of the sun? To which our interpreter answered, that the sun had also begotten him, and given him a language to understand him, his master the admiral, and others; the sun knew well that they dwelt there, but because that great light had many other businesses, and because his master was but young, he sent him no sooner. The Indian interpreter," continues Alarchon, "then turning to me, said suddenly, "Comest thou, therefore, to be our lord, and that we should serve thee?' 'To which I answered, I came not to be their lord, but rather their brother, and to give them such things as I had. Ho then inquired whether I was the sun's kinsman, or his child? To which I replied I was his son, but those who were with me, though all born in one country, were not his children; upon which he raised his voice loudly and said, 'Seeing thou doest us so much good, and dost not wish us to make war, and art the child of the sun, we will all receive thee for our lord, and always serve thee; therefore we pray thee not to depart hence and leave us.' After which he suddenly turned to the people, and began to tell them that I was the child of the sun, and therefore they should all choose me for their lord."* The Indians appeared to be well pleased with this proposal, and assisted the Spaniards in their ascent of the river to the distance of eighty-five leagues ; but finding it impossible to open a communication with the army under Coronado, Alarchon nut about his ships, and returned to Mexico.t

* Hakluyt, vol. iii. p. 429. Ramusio, vol. iii. B. 356

+ Hakluyt, vol. iii. o. 438,439 
After the expeditions of Coronado and Alarchon, in 1542, the spirit of enterprise among the Spaniards experienced some check, owing probably to the feeling of mortification and disappointment which accompanied the return of these officers. Yet Mendoza, unwilling wholly to renounce the high hopes he had entertained, despatched a small squadron under Rodriguez Cabrillo, which traced the yet undiscovered coast of North America some degrees beyond Cape Mendocino; and in 1596 and 1602, Sebastian Viscaino extended these discoveries along the coast of New-Albion to a river which appears to have been the present Columbia. It has even beeil asserted by some authors, that, four years prior to the voyage of Viscaino, Juan de Fuça, a veteran Spanish pilot, conducted a ship beyond the mouth of the Columbia, and doubling Cape Flattery, entered the Straits of Georgia, through which he passed till he came to Queen Charlotte's Sound. De Fuça imagined, not unnaturally, considering the imperfect and limited state of geographical knowledge, that he had now sailed through the famous and fabulous Strait of Anian : and that, instead of being in the Pacific as he then actually was, he had conducted his vessel into the spacious expanse of the Atlantic. With this information he returned to Acapulco; but the Spanish viceroy received him coldly, and withheld all encouragement or reward,-a circumstance to which we may perhaps ascribe the cessation fron: this period of all further attempts at discovery by this nation upon the north-west coast of America. The whole voyage of De Fuça, however, rests on apocryphal authority.

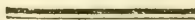

\section{CHAPTER II.}

\section{Russian and English Voyages.}

\section{Behring-Tchirikow-Cook and Clerke-Meares-Vancouver-} Kotzebue.

As the zeal of the Spanish government in extending their discoveries upon the north-west coast of America abated, another great nation, hitherto scarcely known to Europe, undertook at a later period the task which they had aban- 
doned. Russia, within little more than half a century, had grown up from a collection of savage, undisciplined, and unconnected tribes, into a mighty people. Her conquests had spread with amazing rapidity till they embraced the whole of the north of Asia, and under the energetic administration of Peter the Great this empire assumed at once that commanding influence in the scale of European nations which it has continued to preserve till the present times. Among the many great projects of this remarkable man, the solution of the question, whether Asia, on the north-east, was united with America, occupied a prominent place ; and it appears that during his residence in Holland in 1717, he had been solicited by some of the most eminent patrons of discovery among the Dutch to institute an expedition to investigate the subject. The resolution he then formed to set this great point at rest by a voyage of discovery was never abandoned; but his occupation in war, and the multiplicity of those state-affairs which engrossed his attention, caused him to delay its execution from year to year, till he was seized with his last illness. Upon his death-bed he wrote, with his own hand, instructions to Admiral Apraxin, snd an order to have them carried into immediate execution. They directed, first, that one or two boats with decks should be built at Kamtschatka, or at any other convenient place; secondly, that with these a survey should be made of the most northerly coast of his Asiatic empire, to determine whether they were or were not contiguous to America ; and, thirdly, thet the persons to whom the expedition was intrusted should endeavour to ascertain whether on these coasts there was any port belonging to Europeans, and keep a strict look-out for any European ship, taking care also to employ some skilful men in making inquiries regarding the name and situation of the coasts which they discovered,- of all which they were to keep an exact journal, and transmit it to St. Petersburg.

Upon the death of Peter the Great, which happened shortly after these instructions were drawn up, the Empress Catherine entered fully into his views, and gave orders to fit out an expedition for their accomplishment. The command was intrusted to Captain Vitus Behring. Under his orders were two lieutenants, Martin Spangberg and Alexei 'Tchirikow ; and, besides other subaltern officers, they en- 
gaged several excellent ship-carpenters. On the 5 th of Fel ruary, 1725, they set out from St. Petersburg, and on the 16th March arrived at Tobolsk, the capital of Siberia. After a survey of the rivers Irtisch, Ob, Ket, Jenesei, Tungusca, and Jlim, they wintered at Ilim, and, in the spring of 1726 , proceeded down the river Lena to Jakutzk. The naval stores and part of the provisions were now intrusted to Lieutenant Spangberg, who embarked on the Juduma, intending to sail from it into the Maia, and then by the Aldan into the Lena. He was followed by Captain Behring, who proceeded by land with another part of the stores, while Lieutenant Tchirikow staid at Jakutzk, with the design of transporting the remainder overland. The cause of this complicated division of labour was the impassable nature of the country between Jakutzk and Ochotzk, which is impracticable for wagons in summer, or for sledges during winter. Such, indeed, were the difficulties of transporting these large bales of provisions, that it was the 30th July, 1727, before the whole business was completed. In the mean time a vessel had been built at Ochotzk, in which the naval stores were conveyed to Bolscheretzkoi in Kamtschatka. From this they proceeded to Nischnei Kamischatkoi Ostrog, where a boat was built similar to the packet-boats used in the Baltic. After the necessary articles were shipped, Captain Behring, determining no longer to delay the most important part of his enterprise, set sail from the mouth of the river Kamtschatka on the 14th of July, steering north-east, and for the first time laying down a survey of this remote and desolate coast. When they reached the latitude of $64^{\circ} 30^{\prime}$, eight men of the wild tribe of the Tschuktschi pushed off from the coast in a leathern canoe, called a baidar, formed of seal-skins, and fearlessly approached the Russian ship. A communication was immediately opened by means of a Koriak interpreter; and, on being invited, they came on board without hesitation. By these natives Behring was informed that the coast turned towards the west. On reaching the promontory called Serdze Kamen, the accuracy of this information was established, for the land was seen extending a great way in a western direction, - a circumstance from which Behring somewhat too hastily concluded, that he had reached the extremest northern point of Asia. He was of opinion that thence the coast must run to the west, and therefore no 
junction with America could take place. Satisfied that he had now fulfilled his orders, he returned to the river Kamtschatka, and again took up his winter-quarters at Nischnei Kamtschatkoi Ôstrog.*

In this voyage it was conjectured by Behring and his officers, from the reports of the Kamtschadales, that in all probability another country must be situated towards the east, at no great distance from Serdze Kamen; yet no immediate steps were taken either to complete the survey of the most northerly coasts of Ochozkoi, or to explore the undiscovered region imrnediately opposite the promontory. In the course of a campaign, however, against the fierce and independent nation of the Tschuktshi, Captain Pawlutzki penetrated by the rivers Nboina, Bela, and Teherna, to the borders of the Frozen Sea; and after defeating the enemy in three battles, passed in triumph to a promontory supposed to be the Tgchukotzkoi Noss. From this point he sent part of his little army in canoes, while he himself conducted the remaining division by land round the promontory, taking care to march along the seacoast, and to communicate every evening with his canoes. In this manner Pawlutzki reached the promontory which is conjectured to have been the farthest limit of Behring's voyage, and thence by an inland route returned, on the 21 st October, 1730 , to Anadirsk, having advunced an important step in ascertaining the separation between America and the remote northeasterly coast of Asia.

Although the separation of the two continents had been thus far fixed, a wide field of discovery yet remained unexplored; and in 1741, Behring, Spangberg, and Tchirikow once more volunteered their services for this purpose. These offers were immediately accepted; the captain was pro. moted to the rank of a commander, the two lieutenants were made captains, and instructions drawn up for the conduct of the expedition, in which it was directed that the destination of the voyages should be eastward to the continent of America, and southward to Japan, while, at the same time, an endeavour was to be made for the discovery of that northern passage through the Frozen Sea which

* Harris's Collection of Voyages, vol. ii. p. 1020, 1021 ; Coxe's Rugsian Discoveries, p. 23, 24, 94 . 
had been so repeatedly but unsuccessfully attempted by other European nations. The voyage to Japan, under the command of Captain Spangberg and Lieutenant Walton, was eminently successful; and one of its material results was the correction of a geographical error of considerable magnitude, by which that island had hitherto been placed under the same meridian as Kamtschatka, instead of $11^{\circ}$ more to the westward. The expedition of Behring, no less important and satisfactory, was destined to be fatal to its excellent commander. After a winter spent in the harbour of Awatscha, or Petropalauska, on the west side of the great peninsula of Kamtschatka, Behring got his stores on board the two packet-boats built at Ochotzk, expressly for the intended American discoveries. The first of these, the St. Peter, was that in which the commander embarked; the second, the St. Paul, was intrusted to Captain Tchirikow. Along with Behring went Lewis de Lisle de la Croyere, Professor of Astronomy, while Mr. George William Steller, an experienced chymist and botanist, accompanied Tchirikow.

All things being ready, a council of officers was held, in which the question regarding the course they should steer was considered, and it happened, unfortunately for the expedition, that an important error had crept into the map presented by the Academy of Sciences at St. Petersburg to the senate, in laying down a coast south-east from Awatscha, extending fifteen degrees from west to east, while no land was marked due east. At this spot were written on the map the words "Land seen by Don Jean de Gama:" and, trusting to the accuracy of this information, it was determined to steer first south-east-by-east, in the hope of discovering this continent ; after which they might follow its coasts as a guide towards the north and east. On the 4 th of June, 1741, they accordingly weighed anchor and steered south-east-bysouth, till, on the 12th, they found themselves in latitude $46^{\circ}$, without the slightest appearance of the coast of De Gama. Convinced at last of their error, they held on a northerly course as far as $50^{\circ}$ north latitude, and were just about to steer due east, with the hope of reaching the continent of America, when the two ships were separated in a violent storm accompanied by a thick fog. Behring exerted every effort to rejoin his consort; but all proved in vain. He 
cruised for three days between $50^{\circ}$ and $51^{\circ}$ north latitude, after which he steered back to the south-east as far as $45^{\circ}$; but Tchirikow, after the storm, had taken an easterly course from $48^{\circ}$ north latitude, so that they never met again.

Both, however, pursued their discoveries simultaneously, and on the 15 th of July, being in $56^{\circ}$ north latitude, Tchirikow reached the coast of America. The shore proved to be steep and rocky, and, in consequence of the high surf, he did not venture to approach it, but anchoring in deep water, despatched his mate, Demetiew, with the long-boat and ten men on shore. The boat was provisioned for some days, the men armed and furnished with minute instructions as to their mode of proceeding, and the signals by which they were to communicate with the ship. But neither mate, men, nor barge were ever again heard of. This was the more mysterious, as all at first appeared to go well with them. The barge was seen from the ship to row into a bay behind a small cape, and the appointed signals were made, intimating that she had landed in safety. Day after day the signals agreed on continued from the shore. The people on board began at last to think that the barge had probably received damage in landing, and could not return till she was repaired, and it was resolved to send the small boat on shore, with the boatswain Sawelow and six men. Among these were some carpenters and a careener, well armed and provided with the necessary materials, and the boatswain had orders to return with Demetiew in the longboat the moment the necessary repairs were completed. But neither mate nor hoatswain ever came back; and the most dark surmises of their fate were excited by the cessation of the signals, and the continual ascent of a large volume of smoke from the landing-place. Next day, however, a revival of hope was felt at the sight of two boats which were observed rowing from the land towards the ship. It was believed to be Denietiew and Sawelow ; and Tchirikow ordered all hands on deck, to prepare for setting sail on a moment's warning. A few minutes changed these cheerful anticipations into sorrow ; for, as the boats approached, it was discovered that they were filled by American savages, who, seeing many persons on deck, instantly shipped their paddles and remained at a cautious distance. They then stood up, and crying with a loud voice "Agai, agai!" re* 
turned with great speed to the shore. A strong west wind now rose and threatened to dash the vessel on the rocky coast, so that they were obliged to weigh anchor and put to sea without the slightest hope of hearing any further intelligence of their men; for they had no more small boats, and all communication with the shore was cut off. Tchirikow, however, cruised some days in the neighbourhood, and when the weather became milder, returned towards the spot where his people landed; but all appeared silent, lonely, and uninhabited: and in a council of the officers, it was determined to set out on their return, though with the most poignant regret at being obliged to leave this remote and desolate coast without $\mathrm{f}_{1}$ earing the slightest account of their companions. They arrived at Kamtschatka on the 27 th of July.* No news of the fate of Demetiew and Sawelow ever reached Russia; but it is evident that they had been successively attacked and murdered by the savages. "The natives of this part of the north-west coast of America," says Captain Burney, "live principally by hunting and catching game, in which occupations they are in the continual practice of every species of decoy. They imitate the whistlings of birds, - they have carved wooden masks resembling the heads of animals, which they put on over their own and enter the woods in masquerade. They had observed the signals made to the ship by the Russian boat which first came to land; and the continuance of signals afterward seen and heard by the Russians on board were doubtless American imitations." $†$

Exactly three days after Tchirikow descried land, it appears that Commodore Behring also got sight of the continent in $58^{\circ} 28^{\prime \prime}$, or, according to another account, $60^{\circ}$ north latitude. The prospect was magnificent and awful, exhibiting high mountains covered from the summits with snow. One of these, far inland, was particularly remarked: it was plainly discernible sixteen German miles out at sea; and Steller says in his journal, that in all Siberia he had not met with a more lofty mountain. being much in want of water, approached the coast with

* Muller, Découvertes faites par les Russes, vol. 1. p. 254.

† Burney's History of North-eastern Voyages of Discovery, p. 180.

Ilvid. p. 164. 
the hope of being able to land. He accordingly reached the shore on the 20th July, and anchored under a large island not far from the continent. A point of land projecting into the sea at this place they called St. Elias Cape, as it was discovered on that saint's day; while another headland was denominated St. Hermogenes; and between these lay a bay, in which, if it became necessary to take shelter, they trusted they would find security. Two boats were now launched, in the first of which Kytrof, the master of the fleet, was sent to examine the bay, while Steller proceeded with the other to fetch water. Kytrof found a convenient anchorage ; and on an adjacent island were a few empty huts formed of smooth boards, ornamented in some places with rude carving. Within the huts they picked up a small box of poplar, a hollow earthen ball in which a stone rattled, conjectured to be a child's toy, and a whetstone, on which it appeared that copper knives had been sharpened.* Steller, on the other hand, near the spot where he landed, discovered a cellar in which was a store of red salmon, and a sweet herb dressed for food in the same manner as in Kamtschatka. Near them were ropes, and various pieces of household furniture and of domestic utensils. At a short distance he came to a place where the savages had recently dined,beside which they found an arrow, and an instrument for procuring fire exactly similar to that used for the same purpose in Kamtschatka. The sailors who fetched the fresh water had found two fireplaces with the ashes newly extinguished, and near them a parcel of hewn wood, with some smoked fishes like large carp. They observed also marks of human footsteps in the grass, but no natives were seen. In case, however, they should return, some small presents, such as it was conjectured might be suited to their tiste or their wants, were left in the huts. These consisted of a piece of green glazed linen, two iron kettles, two knives, two iron Chinese tobacco-pipes, a pound of tobacco leaves, and twenty large glass beads. Steller, an enthusiastic naturalist, entreated that he might have the command of the small boat and a few men, to complete a more accurate survey of this new coast ; but Behring, who was from his advanced age rather timid and over-cautious, put a decided

¿Coxe's Russian Discoveries, p. 42, 43. F 2 
negative upon the proposal; and his scientific companior, having climbed a steep rock to obtain a view of the adjacent country, found his progress interrupted by an immediate order to come on board. "On descending the mountain," says he in his journal, "which was overspread with a forest without any traces of a road, finding it impassable, I reascended, looked mournfully at the limits of my progress, turned my eyes towards the continent which it was not in my power to explore, and observed at the distance of a few versts some smoke ascending from a wooden eminence. * * * Again receiving a positive order to join the ship, I returned with my collection."*

Having put to sea next day, the 2lst of July, they found it impossible, according to their original intention, to explore the coast as far as $65^{\circ}$ north latitude, as it seemed to extend indefinitely to the south-west. It was studded with many small islands, the navigation through which, especially during the night, was dangerous and tedious. On the 30 th of July they discovered, in latitude $56^{\circ}$, an island which they called Tumannoi Ostrog, or Foggy Island; and soon after the scurvy broke out with the most virulent symptoms in the ship's crew; so that, in hopes of procuring water, they again ran to the north, and soon discovered the continent, with a large group of islands near the shore, between which they came to anchor. These they called the Schumagins, after the name of one of their men who died there. While at this anchorage the weather became boisterous, and some brackish water procured from one of the largest islands increased the virulence of the disease, which prevailed to an alarming degree. All attempts to put to sea proved for some days unsuccessful, owing to the strong contrary winds; and at length one morning they were roused by a loud cry from one of the islands, upon which they saw a fire burning. Soon after, two Americans rowed towards the ship in their canoes, which in shape resembled those of Greenland and Davis's Strait. They stopped, however, at some distance, and it was discovered that they not only understood the language of the calumet, or pipe of peace, employed by the North American Indians, but had these symbolical instruments along with them. 'They were sticks with hawks' wings

* Coxe's Russian Discoveries, p. 40, 41. 
attached to one end. It was at first impossible to induce the natives to come on board; and Behring, anxious to establish a communication, and to become acquainted with the country, despatched Lieutenant Waxel in the boat with nine men well armed, among whom was a Tschuktschian or Koriak interpreter. It was found, however, that the savages were utterly ignorant of his ianguage ; and Waxel, having sent some men on shore, who fastened the boat by a long rope passed round a rock on the beach, commenced a friendly intercourse by means of signs. The Americans were disposed to be on the most amicable terms with their new acquaintances, giving them whales' flesh, the only provision they appeared to possess; and at last one of them so far overcame his fears as to join the Russian lieutenant in the boat, which still lay a little way from the shore. Anxious to conciliate his favour and treat him with distinction, Waxel somewhat thoughtlessly presented him with a cup of brandy; but the effect proved the reverse of what was expected. He made the most ludicrous wry faces, spit violently out of his mouth all that he had not swallowed, and cried aloud to his companions on the shore, complaining of the treatment he had experienced. "Our men," says Mr. Steller in his journal, "thought the Americans had sailors' stomachs, and endeavoured to remove his disgust by presenting him with a lighted pipe of tobacco, which he accepted; but he was equally disgusted with his attempt to smoke. The most civilized European would be affected in the same manner if presented with toad-stool, or rotten fish and willow bark, which are delicacies with the Kamtschadales." It was evident he had never tasted ardent spirits or smoked tobacco till this moment; and aithough every effort was made to sooth him and restore his confidence, by offering him needles, glass beads, an iron kettle, and other gifts, he would accept of nothing, and made the most eager and imploring signs to be set on shore. In this it was judged right to gratify him, and Waxel, at the same time, called out to the sailors who were on the beach to come back; the Americans made a violent attempt to detam them, but two blunderbusses were fired over their heads, and had the effect of making them fall flat on the ground, while the Russians escaped and rejoined their companiorss.

This adventure gave them an opportunity of examining 
this new people, now for the first time visited by Europeans. "The islanders were of moderate stature, but tolerably well proportioned; their arms and legs very fleshy. Their hair was straight and of a glossy blackness; their faces brown and flat, but neither broad nor large; their eves were black, and their lips thick and turned upwards; their necks were short, their shoulders broad, and their bodies thick but not corpulent. Their upper garment was made of whales' intestines, their breeches of seals' skins, and their caps formed out of the hide of sea-lions, adorned with feathers of various birds, especially the hawk. Their nostrils were stopped with grass, and their noses as flat as Calmucks'; their faces painted, some with red, others with different colours; and some of them, instead of caps, wore hats of bark, coloured green and red, open at the top, and shaped like candle-screens, apparently for protecting the eyes against the rays of the sun. These hats might lead us to suppose that the natives of this part of America are of Asiatic descent; for the Kamtschadales and Koriaks wear the like, of which several specimens may be seen in the Museum at St. Petersburg." *

At this time Behring being confined by severe sickness, the chief command fell on Waxel, who was preparing to sail, when seven Americans came in their boats to the ship's side, and two of them catching hold of the entrance-laduer, presented their bonnets and a carved image of bone, bearing some resemblance to a human figure. They likewise held up the calumet, and would have come aboard, but the sailors were taking up the anchor, and the breeze freshening, they were under the necessity of making towards the shore as quickly as possible. There was time, however, to give a few presents, and as the ship passed by the point where they stond, she was saluted with loud and friendly shouts. $f$

They had now to struggle against a tedious continuance of westerly wind, accompanied with thick fogs, which rendered the navigation in these unknown seas perilous in the extreme. On the 24th of September the mist cleared away, and disclosed a high and desolate coast, which a strong south wind made it dangrerous to approach. The majority of the crew were by this time disabled by the scurvy, and

* Coxe's Russian Discoveries, n. 63.

† Burney's North-easteru Vosages of Discoverv. D. 170 
the rest so weak, that to manage the vessel during the tempestuous weather was almost impossible. A violent gale soon after began to blow from the west, which gradually increased, and drove the ship far to the south-east. The storm continued for seventeen days, - a fact to which there are few parallels in the history of shipwrecks; and the pilot, Andrew Hesselberg, who hat served for fifty years in several parts of the world, declared he had never witnessed so long and terrible a gale. Meanwhile they carried as little sail as possible, and were driven for a fortnight at the mercy of the wind, under a sky as black as midnight, so that all the time they saw neither sun nor stars. When the storm abated, they found themselves, by the ship's reckoning, in $48^{\circ} 18^{\prime \prime}$ north latitude. Steller, in his journal, draws a striking picture of their extreme misery :- "The general distress and mortality," says he, "increased so fast, that not only the sick died, but those who still struggled to be numbered on the healthy list, when relieved from their posts, fainted and fell down dead, of which the scantiness of water, the want of biscuits and brandy, cold, wet, nakedness, vermin, fear, and terror were not the least causes."* In these circumstances it became difficult to determine whether they should return to Kamtschatka or seek a harbour on the nearest American coast. At last, in a council of officers, they embraced the first $\sigma_{f}$ these alternatives, and again sailed north, after which they steered towards the west.

On the 29th of October they approached two islands resembling the two first of the Kurilian group. The longwished-for coast of Kamtschatka, however, did not appear, and the condition of the vessel and crew began to be deplorable. The men, notwithstanding their diseased state and want of proper food, were obliged to work in the cold; and as the continual rains had now changed into hail and snow, and the nights shortened and grew darker, their sufferings were extreme. The commodore himself had been for some time totally disabled by disease from taking an active command, his wonted energy and strength of mind left him, and he became childishly suspicious and indolent. Among the seamen the sickness was so dreadful, that the fwo sailors whose berth used to be at the rudder were led

* Coxe's Russian Discoverles, p. 65. 
to it by others, who themselves could walk with difficulty. W'hen one could steer no longer, another equally feeble was supported to his place. Many sails they durst not hoist, because no one was strong enough to lower them in case of need, while some of the sheets were so thin and rotten that a violent wind would have torn them to pieces. The rest of this interesting but deeply affecting voyage may be given in the excellent abstract of Captain Burney. "On November 4th, at eight in the morning, they once more saw land; but only the tops of the mountains at first appeared, and the shore was so distant, that, although they stood towards it the whole day, night came on before they could get near enough to look for anchorage. At noon that day they made their latitude by observation to be $56^{\circ}$ north. On the morning of the 5th, it was discovered that almost all the shrouds on the starboard side of the ship were broken, which happened from contraction and tenseness caused by the frost; for, without other mention made of the weather, it is complained that the cold was insupportable. In this distress the commodore ordered the lieutenant to call all the officers together, to consult on their best mode of proceeding; and the increased numbers of the sick, with the want of fresh water, determined them at all hazards to seek relief at this land. The wind was northerly, and they had soundings at the depth of thirty-seven fathoms, with a sandy bottom. They now steered in towards the land, west-southwest and south-west, and two hours after, at five in the evening, they anchored in twelve fathoms, the bottom sand, and veered out thre-quarters of a cable. The sea now began to run high, and at six the cable gave way. Another anchor was let go, yet the ship struck twice, though they found, by the lead, five fathoms depth of water. The cable quickly parted; and it was fortunate a third anchor was not ready, for while they were preparing it a high wave threw the ship over a bank of rocks, where all at once she was in still water. They now dropped their anchor in four fathoms and a half, about 600 yards from the land, and lay quiet during the rest of the night; but in the morning they found themselves surrounded with rocks and breakers. They were certain that the coast of Kamtschatka was not far distant; but the condition of the ship and the crew, with the advanced season of the year, rendered it apparent that they 
must remain upon this land all winter. Those who were able to work went on shore to prepare lodgings for the sick. This they accomplished by digging pits or caverns between some sandhills near a brook which ran from a mountain to the sea, using their sails as a temporary covering. There was no appearance of inhabitants ; nor were any trees seen, although driftwood was found along the shore. No grass nor antiscorbutic herbs were discoverable; the island, indeed, was so deeply covered with snow, that even if it produced any antiseptic plants, the patients had not strength to lay them open; and at this time the Russians were little acquainted with the proper remedies for this dreadful disease. On the Sth of November they began to transport the sick to the miserable habitations which had been prepared for them; and it was remarkable that some who seemed the least reduced, expired the moment they were exposed to the fresh air, and others in making an attempt to stand upon deck.*

On the 9 th of November, Behring himself was carried ashore by four men on a handbarrow, carefully secured from the air. The ship had been cast on the east side of the island, and the coast was examined both to the north and south; but no traces of inhahitants were found. Along the shores were many sea-otters, and the interior swarmed with blue and white foxes. "We saw," says Steller in his journal, "the most dismal and terrifving objects: the foxes mangled the dead before they could be buried, and were even not afraid to approach the living and helpless who lay scattered here and there, and smell to them like dogs. This man exclaimed that he was perishing of cold; the other complained of hunger and thirst; and their mouths were so much affected by scurvy that their gums grew over their teeth like a sponge. The stone-foxes, which swarmed round our dwellings, became so bold and mischievous, that they carried away and destroyed different articles of provision

* "It must," says Captain Burney, "be within the memory of many, the great care with which the apartments of the sick were guarded against the admission of fresh air, and in few instances more than in what was called the sick-berth on board a ship of war, where it was customary to keep a numler of diseased persons labouring under different maladies enclosed and crowded together; and fortunately, since the date of this expedition, the management of the sick with respect to air has undergone a very essential reform." 
and clothing. One took a shoe, another a boot, a third a glove, a fourth a coat; and they even stole the iron implements; while all attempts to drive them away were ineffectual."**

Lieutenant Waxel, on whom, since the illness of the commodore, the command devolved, and Kytrow, the ship. master, continued healthy at sea; and the necessity for exertion, in seeing every thing sent on shore, had a favourable effect in repelling the attacks of the disease. At last, however, they too were laid up, and soon became so weak that, on the 21st of November, they were carried ashore like the rest. During this dreadful residence on the island, the men lived chiefly on the flesh of the sea-otters, which was so hard and tough that it could scarcely be torn to pieces by the teeth. The intestines were mostly used for the sick; and Steller, in his descriptions of the marine animals of these regions, reckons the flesh of the sea-otter as a specific against the scurvy. When not wanted for food they were killed for their fine skins, 900 being collected on the island, and equally divided among the crew. A dead whale, which was thrown upon the coast, they called their magazine, as it proved a resource when nothing better could be got. The flesh was cut into small pieces, which they boiled a long time to separate the oil from it as much as possible, and the remaining hard and sinewy parts they swallowed without chewing.

In this miserable manner they continued to support life; but some of the crew sunk daily under the disease, and on the 8th of December the commodore expired. Behring was an officer of extraordinary merit ; and, untíl reduced by the disease of which he became the victim, endowed with unshaken perseverance and energy. His voyage set at rest the disputed point regarding the separation of the two continents of Assia and America; and he has deservedly bequeathed his name to the strait which he was the first to explore, and the desolate island on which he died. It is melancholy to think, that after the exertions he had made in the cause of naval discovery, his iife terminated so miserably; for it may almost be said that he was buried alive : the sand rolled down continually from the side of the cav-

* Coxe's Russian Discoveries, p. 73, 74. 
ern in which he lay, and at last covered his feet; nor would he suffer it to be removed, saying he felt warmth from it, when he was cold in all other parts; it thus gradually increased upon him till his body was more than half-concealed; so that when he at last expired, it was found necessary to unearth him previously to his being interred. "Behring," says Steller, who was by no means disposed to exaggerate the good qualities of his commander, "displayed in his illness the most affecting resignation to the will of the Supreme Being, and enjoyed his understanding and speech to the last. He was convinced that the crew had been driven on an unknown land; yet he would not terrify others by declaring his opinion, but cherished their hopes and encouraged their exertions. He was buried according to the Protestant ritual, and a cross was erected over his grave to mark the spot, and to serve also as an evidence that the Russians had taken possession of the country."*

Soon after the death of the commodore the whole crew were sheltered from the severity of the winter in subterranean dwellings contiguous to each other, and recovered so much strength by the use of sweet and excellent water, and the flesh of the sea-animals killed in hunting, that their existence became comparatively comfortable. Of the manner in which they passed their time during the dreary winter months, from December to May, Steller has left us in his journal a minute and interesting account. In March the sea-otters disappeared, either from the instinct of changing their abode at particular seasons of the year, or banished by continual persecution; but their place was supplied by other marine animals, which, in their turn, also left them. "To supply ourselves with fuel," says Steller, "was likewise a considerable labour: as the island produced nothing but willow-bushes, and the drift-wood was often deeply buried in the snow till the end of March, we were compelled to bring it from a distance of even fifteen or sixteen versts; and our load upon these expeditions amounted to from sixty to eighty pounds, besides our hatchets and kettles, with the necessary implements for mending our shoes and clothes. In April, however, we were relieved from this labour by the thaw and breaking up of the vessel." An anecdote of an

* Coxe's Russian Discoveries, p. 79. 
escape made by them in hunting, as it is given by the same lively writer, presents us with a striking picture of their manner of life upon the island. "On the 5th of April," says he, "during a gleam of favourable weather, Steneser and myself, with my Cossack and a servant of Behring, went on a hunting expedition. Having killed as many seaotters as we were able to carry, we made a fire in a cliff, where we proposed to pass the night. At midnight a violent hurricane arose, and the snow fell in such quantities that we should have been buried had we not run continually backwards and forwards. In the morning, after a long and fruitless search for shelter, we resigned ourselves to our fate; but the Cossack fortunately discovered a large cavern, which seemed to have been formed by an earthquake, where we entered with our provision and wood. It afforded a secure retreat from the weather, contained a cavity in which we could hide our provisions from the depredations of the stonefoxes, and was provided with an aperture which served the purpose of a chimney. The cave and bay, which were named in compliment to me, were inhabited by numerous foxes, which retired on our approach through the chimney ; but the smoke from our fire caused such a spitting and sneezing among them as gave no small diversion to the party. At night, however, they occasionally returned into the cavern, and amused themselves with taking away our caps, and playing other similar gambols. On the 4 th we returned to our abode with a rich booty, and were received with great delight by our companions, who thought us lost."**

On the 6th of May, such of the crew as were able to work began to build from the relics of the wreck a vessel, which was intended to carry the survivors to Kamtschatka. Their number was now reduced to forty-five, thirty having died on the island, including the three carpenters; but a Siberian Cossack named Starodubzow, who had for some time worked as a shipwright at Ochotzk, superintended the building of the new ship. At first they were put to great inconvenience from a deficiency of tar; but by an ingenious contrivance it was extracted from the new cordage which

* We have availed ourselves of Coxe's translation of this passage, as published in his Russian Discoveries, p. 85,86 
they had to spare. After being cut and picked, they put it into a large copper kettle, having a cover fitting close, with a hole in the middle. They then took another vessel with a similar cover, which they fixed firm in the ground, and upon this set the copper kettle turned upside down, the apertures in the lids being placed exactly against each other. Part of this machinery was then buried in the earth, and a fire kindled round what was above ground, by which means the tar of the new cordage melted, and ran into the inferior vessel. This contrivance having removed their greatest difficulty, by the 10th of August the new vessel was launched, and on the 16th, Lieutenant Waxel set sail with the melancholy remnant of his erew ; but, owing to contrary winds, they did not make the coast of Kamtschatka till the 25th, although from Behring's Island the distance was not more than thirty German miles. On the 27th they anchored in Awatchka Bay; and the Cossack Starodubzow, to whose efforts in constructing the vessel the preservation of the crew was mainly owing, received the rank of sinbojarski, a degree of Siberian nobility. Such is an account of the celebrated and unfortunate expedition of Commodore Behring, of which the results were highly important to geographical science, although dearly bought by the death of so many brave men.

Although Lord Mulgrave had failed in his attempt to discover, by a northerly course, a communication between the Pacific and Atlantic Oceans, ${ }^{*}$ the British government did not abandon all hope; and in 1776, Captain James Cook, who had already established his reputation as the greatest of modern navigators, was selected by the Admiralty to conduct another expedition, reversing only the plan, and endeavouring to sail from the Pacific into the Atlantic, instead of from the Atlantic into the Pacific.

In prosecution of this plan, on the 12th of July, 1776, Cook sailed from Plymouth Sound in the Resolution, leaving instructions for the Discovery, the command of which was intrusted to Captain Charles Clerke, to join him at the Cape. From that place the two ships proceeded, in a course marked by important discoveries, through the southern hemisphere, by Van Diemen's Land, New-Zealand, Otaheite, and the

* Polar Seas and Regions, p. 260-267. 
Sandwich Islands. They then steered north-eastward, and on the 7th of March, in latitude $44 \frac{1}{2}^{\circ}$ north, came in sight of the American continent at the coast of New-Albion. Owing to unfavourable winds, which forced the ships to the south, it was the 29th before Cook anchored in Nootka Sound, where he was soon visited by thirty boats of the natives, carrying each from three to seven or eight persons, both men and women. At first none of the Americans would venture within either ship, and from the circumstance of their boats remaining at a short distance all night, as if on watch, it was evident they regarded the arrival of the strangers with much suspicion. A friendly intercourse, however, was soon established; and although theft, particularly of any iron utensil, was unscrupulously committed, they were pretty fair and honest in their mode of barter. "They were," says Cook, "docile, courteous, and goodnatured; but quick in resenting what they looked upon as an injury, and, like most other passionate people, as soon forgetting it. Their stature was rather below the common size of Europeans; and although at first, owing to the paint and grease which covered their skins, it was believed that they were of a copper complexion, it was afterward discovered that they were in reality a white people. They were well armed with pikes, some headed with bone and many with iron; besides which they carried bows, slings, knives, and a short club, like the patow of the New-Zealanders; their arrows were barbed at the point, and the inner end feathered." A dispute occurred after the arrival of the English, between the inhabitants of the northern and southern coasts of the sound; but a pacific treaty was concluded, and the event celebrated by a species of music, in which they bore alternate parts. "Their songs," says Captain Burney, who was himself present, "were given in turn, the party singing having their pikes erected. When the first finished they laid down their pikes, and the other party reared theirs. What they sang was composed of few notes, and as wild as could have been expected; yet it was solemn and in unison, and, what I thought most extraordinary, they were all well in tune with each other. The words were at times given out by one man, as a parish-clerk gives out the first line of a psalm."*

* Burney's North-eastern Voyages of Discovery, p. 213. 
It appeared evident to Captain Cook that previous to this the inhabitants had never entertained any direct communication with Europeans. "They were not startled," says he, " by the report of a musket, till one day, upon endeavouring to prove to us that arrows and spears would not penetrate their war-dresses, a gentleman of our company shot a musket-ball through one of them folded six times. At this they were so much staggered, that their ignorance of firearms was plainly seen. This was afterward confirmed when we used them to shoot birds, the manner of which confounded them." On the ships leaving Nootka Sound, the natives accompanied their farewell with a singular exhibition: "When the anchor was heaving up," says Burney, "they assembled in their boats, which covered the cove, and began a song, in which they flourished the swords, saws, hatchets, and other things which they had obtained from us. In the midst of this valedictory chorus, one man, mounted on a stage of loose boards, which was supported by the people in the nearest canoes or boats, danced with a wooden mask on, which he occasionally changed, making himself resemble sometimes a man, sometimes a bird, and sometimes an animal. Of these masks they have great variety, and they parted with them willingly, except those of the human face ; if they sold any of these, it seemed to be with some repugnance, as if they were parting with the image of a friend or a relation, and were ashamed to be seen so doing." *

From Nootka Sound Captain Cook made a survey of the coast by Mount St. Elias, till he arrived at a cape which turned short to the north, to which he gave the name of Cape Hinchinbroke; thence he proceeded to Prince William's Sound; after which he pursued the coast to the west, which was found to take a southerly direction, as described by Behring and Tchirikow. These navigators, however, as we have seen, had not made a very particular examination; and although the tenor of Cook's instructions did not permit him to devote much time to the exploring rivers or inlets, till he reached the latitude of $65^{\circ}$, still that eminent officer deemed himself at liberty to complete an accurate survey of this hitherto undiscovered coast, from the arm of the sea

- Burney's North-eastern Voyages of Discovery, p. 217, 218. G2 


\section{COOK CROSSES BEHRING'S STRAIT TO ASIA.}

afterward denominated Cook's Inlet round the great penin sula of Alaska, terminating in Cape Oonamak. He thence proceeded along the shores of Bristol Bay, till he doubled Cape Newenham, from which he steered in a north-easterly direction and anchored in Norton Sound. Leaving this the ships entered Behring's Strait, and followed the coast to the north-west, till they doubled a promontory situated in $65^{\circ}$ $45^{\prime \prime}$ north latitude, which they named Prince of Wales Cape, regarding it as the western extremity of all America hitherto known. Soon after, in the evening, they discerned the coast of Asia, and standing across the strait came to anchor in a bay of the Tschuktschi country, near a village from which the natives crowded to the shore. Observing this, Cook landed with three boats well armed, and was received by the Tschuktschi with cautious courtesy. About forty men, armed each with a spontoon, besides bow and arrow, stood drawn up on a rising ground close by the village, and as the English drew near, three of them came down towards the shore, politely taking off their caps and making low bows. On seeing some of the English leap from their boats they retired, and expressed by signs their desire that no more should land; but when Cook advanced alone, with some small presents in his hand, their confidence was restored, and they exchanged for them two fox-skins and two seahorse-teeth. All this time they never laid down their weapons, but held them in constant readiness, except for a short time, when four or five persons disarmed themselves to give the English a song and a dance; even then, however, they placed them in such a manner that they could reach them in an instant, and evidently for greater security they desired their audience to sit down during the dance. This Asiatic people, although dwelling within fifty miles of the American coast, were evidently a different race from the inhabitants of the shores of Beluring's Strait. All the Americans whom the English had seen since their arrival on the coast were low of stature, with round chubby faces and high cheek-bones. The Tschuktschi, on the contrary, had long visages, and were stout and well made. Several things which they had with them, and more particularly their clothing, showed a degree of ingenuity surpassing what one could expect among so northern a people. Their dress consisted of a cap, frock, breeches, boots, and gloves, 
all made of leather or skins extremely well dressed, some with the fur on, some without it, and the quivers which contained their arrows were made of red leather neatly embroidered, and extremely beautiful.*

From this bay the ships again stood over to the northeast, and continuing their cxamination of the American coast, Cook soon found himself surrounded by the dreary features which mark the scenery of the polar latitudes; a dark and gloomy sky, thick showers of snow and hail, and immense fields and mountains of ice, covered in some places by the huge forms of the walrus or seahorse, which lay in herds of many hundreds, huddling like swine one over the other. The flesh of these animals, when newly killed, was preferred by the crew to their common fare of salt meat, but within four-and-twenty hours it became rancid and fishy. From a point of land, which was denominated Cape Mulgrave, they now explored the coast to the latitude of $70^{\circ}$ $29^{\prime}$, where their progress was arrested by an unbroken wall of ice, apparently stretching from continent to continent. $\dagger$ At this time the nearest land was about a league distant, and the farthest eastern point seen a low headland much encumbered with ice, to which Cook gave the name of Icy Cape, and which, till the recent discoveries of Captain Beechey, constituted the extreme limit of European discovery in that quarter of the globe. It was now the end of August; and as nothing further could be attempted at that season on the American coast, the ships returned to the Sandwich Islands, with the intention of resuming in the succeeding summer the attempt for the discovery of a coinmunication between the Pacific and the Atlantic, - an object which their great commander did not live to execute, having been killed in an unfortunate scuffle with the natives of Owhyee on the 11th of February, 1779. The further conduct of the expedition now fell to Clerke and King, and an attempt was made to penetrate beyond Icy Cape; but the continued fields of ice rendered it utterly abortive. The ships, therefore, having repassed Behring's Strait, came to anchor in the Bay of St. Peter and St. Paul in Kamtschatka. Here Captain Clerke, who had long been in a declining state, died; upon which, to the great satisfaction of the crew and

* Cook's Vnyages, vol. vi. p. 409, 410, 411.

† Ibid. p. 415, 417 . 
officers of both ships, who were sick of the dreary navigation in these inhospitable latitudes, they returned home.

Subsequent to the voyages of Cook and Clerke, the northwest coast of America was visited at different periods by Meares, Vancouver, and Kotzebue ; and though the limit of discovery was not extended beyond Icy Cape, the shores were more minutely examined, and a beneficial commercial intercourse established with the natives. Of Captain Meares's voyages, the great object was to establish a trade between China and the north-west coast of America. For this purpose an association of the leading mercantile men in Bengal fitted out two vessels, - the Nootka, commanded by Meares himself, and the Sea-otter, by Lieutenant Walter Tipping. The Sea-otter in the first instance took a cargo of opium to Malacca, thence she proceeded to America, and is known to have made Prince William's Sound; but after leaving that harbour no accounts of her were ever received, and it appears certain that she and her crew perished at sea. The fate of Meares in the Nootka was scarcely more tolerable. After a tedious and perilous navigation in the China seas, they made their way through the straits between Oonamak and Oonalaska against a current running seven knots an hour, from which they sailed across to America by the Schumagin Islands, and anchored under Cape Douglas.* Thence they proceeded to Prince William's Sound to winter; and their residence here during October, November, and December, though dreary and tedious, was not without its comforts. The natives were friendly, and brought them provisions; they caught plenty of excellent salmon, and the large flocks of ducks and geese afforded constant sport to the officers, and a seasonable supply for the table. But the horrors of an arctic winter began soon to gather round them. The ice closed in upon the ship ; the snow fell so thick that all exercise became impossible; the ducks and geese collected into flocks, and passed away to the southward; the fish totally deserted the creeks ; and the natives, a migratory race, imitating the instinct of these lower species, travelled off in a body with their temporary wigwams to a more genial district. To add to these distresses the scurvy made its appearance; while the sun described

* Heares's Voyages, vol. i. p. 19. Introductory Voyage. 
weekly a smaller circle, and shed a sickly and melancholy light. Even at noon, through an atmosphere obscured by perpetual snows, "tremendous mountains forbade almost a sight of the sky, and east their nocturnal shadows over the ship in the midst of day." The decks were incapable of resisting the intense freezing of the night, and the lower part of them was covered an inch thick with a hoar frost that had all the appearance of snow, notwithstanding fires were kept constantly burning twenty hours out of the twentyfour. Between the months of January and May, twentythree men died of the scurvy, and the rest of the crew were so disabled as to be incapable of any labour; but the sun's return and the commencement of more genial weather produced an instantaneous effect on the health and spirits of the crew. The natives returned, and assured the poor sufferers that the cold must soon be gone, making them understand by signs that the summer would commence about the middle of May; and the sun, which now began to make a larger circle over the hills. not only chased away the huge and gloomy shadows that, like a funeral-pall, had covered the ship, but brought back the fish to the rivers, and the migratory birds to the shore; so that they soon enjoyed an ample supply of fresh food. On the 17th of May, a gerieral breaking up of the ice took place throughout the cove, and the feeling that they were once more in clear water, with the prospect of soon leaving a scene of so much distress and horror, cheered the minds of the crew with inexpressible comfort.* These happy anticipations were soon realized by their sailing from Prince of Wales' Sound on 21st June, and reaching the hospitable cluster of the Sandwich Isles, where such was the effect of the genial climate, that in ten days' residence every complaint had disappeared. On the $2 \mathrm{~d}$ of September they left the Sandwich Islands, and arrived on the 20th October at Macao in China.

It may easily be imagined, that during so disastrous a sojourn on the American shore, little or no progress could be made in the survey of the coast, which was rugged; and at no great distance were mountains, covered with thick woods for about two-thirds of their ascent, beyond which they terminated in immense masses of naked rock. The 
black-pine grew in great plenty, and a few black-currant bushes were noticed, but no other kind of fruit or vegetable. The number of savages seen by Meares did not exceed five or six hundred, and these had no fixed place of abode, but wanciered up and down as fancy or necessity impelled them. They were strong and athletic, rather exceeding the common stature of Europleans, with prominent cheek-bones, round flat faces, eyes small and black, and hair, which they cut short round the head, of the same jetty colour. A slit in the under lip, parallel to the mouth, and a perforation in the septum of the nose, in which was inserted a large quill or a piece of bark, gave them a hideous look; while a singular practice of powdering their hair with the down of birds, allowing the frostwork and icicles to hang from the beard, and painting the neck and face with red ochre, increased the savage singularity of their appearance. Their clothing consisted of a single frock of the sea-otter skin, reaching to their knees. When employed in their canoes, they used a dress made of the entrails of the whale, which covered the head, and ivas so disposed that it could be tied round the hole in which they sat, so as to prevent the water from getting into the canoe, while it kept the lower part of the body warm and dry. Their hardihood and capacity of enduring pain astonished the English, and was remarkably evinced upon an occasion mentioned by Meares :- "In the course of the winter," says he, "among other rubbish, several broken glass bottles had been thrown out of the ship, and one of the natives, who was searching among them, cut his foot in a very severe manner. On seeing it bleed, we pointed out what had caused the wound, and applied a dressing to it, which he was made to understand was the remedy we ourselves applied on similar occasions; but he and his companions instantly turned the whole into ridicule, and at the same time taking some of the glass, they scarified their legs and arms in a most cruel and extraordinary manner, informing us that nothing of that kind could ever hurt them."*

The disastrous result of this first expedition did not deter either Meares or his liberal employers from hazarding a recond voyage to the same coast, which was attended with

* Meares's Voyages, vol. i. Introductory Voyage, p. 66. 
more important results. The Felice, of 230 tons burden, and the Iphigenia, of 300 , were fitted out on this adventure; the command being given to Captains Meares and Douglas. Both vessels were copper-bottomed and strongly built, and their crews consisted of Europeans and Chinese, among whom were some excellent smiths, shipwrights, and other artisans. The taking the Chinamen aboard was an experiment. Before this time they had never formed part of the crew of an English merchant-ship; and it is but justice to say that they proved hardy, good-humoured, and industrious. Two other very interesting passengers were on board of Captain Meares's ship,-Teanna, a prince of Atooi, one of the Sandwich Isles, who had volunteered to leave his native country when Meares visited it during his former expedition; and Comekala, a native of King George's Sound, who had at the same time entreated to be carried to China. Of these two specimens of savage life Teanna was by far the finest, both in moral and in physical qualities. He was about thirty-two years old, near six feet five inches in stature, and in strength almost Herculean. His carriage was dignified, and, in consequence of the respect paid to his superior rank in his own country, possessed an air of distinction, to which his familiarity with European manners had not communicated any stiffness or embarrassment. Comekala, on the other hand, though cunning and sagacious, was a stranger to the generous qualities which distinguished the prince of the Sandwich Isles. He was kind and honest when it suited his own interest; but stole without scruple whatever he wished to have and could not procure by fairer means. Brass and copper were metals which he might almost be said to worship. Copper halfpence, buttons, saucepans,-all possessed in his eyes the highest charms. It was evident that he coveted the brass buttons of the captain's uniform; and his mode of fixing his eyes on the object of his desire, and the pangs of ungratified avarice, as exhibited in the contortions of his countenance, proved matter of much amusement to the crew. The cause of his insatiable thirst for copper became afterward apparent.

In the mean time Captain Meares found it necessary to separate from his consort, whose slow sailing threatened to impede his progress ; and after a long and hazardous passage, the ship anchored in Friendly Cove in King George's 
Sound, abreast of the village of Nootka, on the morning of the 13th of May. Comekala, who for several days had been in a state of high excitation, now enjoyed the genuine delight of once more beholding his native shore; and when his intention of landing was made known, the whole inhabitants poured forth to give him welcome. The dress in which he chose to appear for the first time after so long an absence was very extraordinary: on a former occasion, when visited by Hannapa, a brother chief, he contented himself with an ordinary European suit; but he now, says Meares, arrayed himself in all his glory : his scarlet coat was decorated with such quantities of brass buttons and copper appendages of one kind or other, that they could not fail to procure him profound respect from his countrymen, and render him an object of unbounded admiration to the Nootka damsels. At least half a sheet of copper formed his breastplate; from his ears copper ornaments were suspended; and he contrived to hang from his hair, which was dressed with a long pig-tail, so many handles of copper saucepans, that their weight kept his head in a stiff upright position, which very much heightened the oddity of his appearance. For several of the ornaments with which he was now so proudly decorated Comekala had lived in a state of continual hostility with the cook, from whom he purloined them; but their last and principal struggle was for an erormous spit, which the American prince had seized as a spear, to swell the circumstances of that splendour with which he was preparing to dazzle the eyes of his countrymen. In such a state of accoutrement, and feeling greater delight than ever was experienced on the proudest European throne, the long-boat rowed Comekala ashore, when a general and deafening shout from the crowd assured him of the universal joy felt on his return. The whole inhabitants moved to the beach, welcomed the traveller on shore, and afterward conducted him to the king's house, which none but persons of rank were permitted to enter, and where a magnificent feast of whale blubber and oil was prepared. On the whole, Comekala's reception, and the impression made by his extraordinary costume, evinced his intimate knowledge of the character of his countrymen; for though to the English the effect was irresistibly comic, the natives regarded him with a mixture of silent awe and wonder, which after a while 
broke forth into expressions of universal astonishment and delight.

Not long after this exhibition, two Nootka princes, Maquilla and Callicum, paid a visit to the English. Their little squadron, consisting of twelve canoes with eighteen men each, moved with stately parade round the ship: the men wore dresses of beautiful sea-otter skins, covering them from head to heel; their hair was powdered with the white down of birds, and their faces bedaubed with red and black ochre, in the form of a shark's jaw and a kind of spiral line, which rendered their appearance extremely savage. Eight rowers sat on each side, and a single man at the bow ; whilo the chiefs, distinguished by a high cap, pointed at the crown and ornamented with a small tuft of feathers, occupied a place in the middle. All this was very striking; but the most remarkable accompaniment was the air which they chanted, the effect of which is described by Meares as uncommonly pleasing. " $\mathrm{W}^{\prime} \mathrm{e}$ listened," says he, " to their song with an equal degree of surprise and pleasure. It was indeed impossible for any ear susceptible of delight from musical sounds, or any mind not insensible to the power of melody, to remain unmoved by this solemn unexpected concert. The chorus was in unison, and strictly correct as to time and tune; nor did a dissonant note escape them. Sometimes they would make a sudden transition from the high to the low tones, with such melancholy turns in their variations, that we could not reconcile to ourselves the manner in which they acquired or contrived this more than untaught melody of nature. There was also something for the eye as well as the ear, and the action that accompanied their voices added very much to the impression which the chanting made upon us all. Every one beat time with undeviating regularity against the gunwale of the boat with their paddles; and at the end of every verse they pointed with extended arms to the north and south, gradually sinking their voices in such a solemn manner as to produce an effect not often attained by the orchestras of European nations." This account of the impressive music of the people of Nootka Sound is, the reader may remember, corroborated by Captain Burney.* The ceremony, however, did not end with the

* Supra, p. 76. 
song ; but after rowing twice round the ship, rising up each time as they passed the stern, and vociferating, "Wacush! Wacush!" (friends, ) they brought their canoes alongside, and the two chiefs came on board. Both were handsome men, of the middle size, possessing a mild but manly expression of countenance. They accepted a present of copper, iron, and other articles, with signs of great delight, and throwing off their sea-otter garments, laid them gracefully at the feet of the English, and stood on the deck quite naked. Each of them was presented with a blanket, which they threw over their shoulders with marks of high satisfaction, and descending into their canoes, were paddled to the shore.

A brisk trade in furs now commenced, which, though interrupted occasionally by the petty thefts of the savages, was highly favourable to the commercial interests of the expedition. Skins of the sea-otter, beaver, martin, sable, and river-otter, of the ermine, black-fox, gray, white, and red wolf, wolverine, marmot, racoon, bear, and mountain-sheep, and in addition to all these, of the furred, speckled, and common seal, sea-cow, and sea-lion, were all procured, though some in greater abundance than others. Of these by far the most beautiful and valuable was the skin of the sea-otter. The taking of this animal is attended with considerable hazard; but constant practice has taught the natives both skill and courage. "When it is determined to hunt the sea-otter," says Meares, "two very small canoes are prepared, in each of which are seated two expert hunters. The instruments they employ are bows and arrows, with a small harpoon, which differs somewhat from the instrument of the same kind used in hunting the whale, the shaft being much the same; but the harpoon itself of greater length, and so notched and barbed that when it has once entered the flesh it is almost impossible to extricate it. It is attached to the shaft by several fathoms of suiticient strength to drag the otter to the boat. The arrows employed are small, and pointed with bone formed into a single barb. Thus equipped the hunters proceed among the rocks in search of their prey. Sometimes they surprise the animal when sleeping on his back on the surface of the water: and if they can approach without waking him, which requires infinite caution and skill, he is easily harpooned and dragged to the boat, when a fierce battle often ensues between the otter and 
the hunters, who are frequently severely wounded by his teeth and claws. The more usual manner of taking him, however, is by pursuit, and the chase is sometimes continued for hours. As the animal cannot remain long under water, he skill is here chiefly exerted to direct the canoes in the same line which the otter takes when under water, at which time he swims with a celerity that greatly exceeds that of his pursuers. The moment he dives, therefore, the canoes separate in order to have the better chance of wounding him with their arrows at the moment he rises, although it often happens that this wary and cunning animal escapes, and baffles the utmost skill of his persecutors. Should it happen that the otters are overtaken with their young ones, the instinct of parental affection comes out in its most deep and interesting shape ; all sense of danger and of self-preservation is instantly lost, and both male and female defend their cubs with the most furious courage, tearing out with their teeth the arrows and harpoons fixed in them, and often attacking the canoes themselves. On such occasions, however, their utmost efforts are unavailing, and they and their offspring never fail of yielding to the power of the hunters." *

The hunting the whale, however, is a still nobler sport; and nothing can exceed the skill and intrepidity with which the Americans of Nootka engage in it. When it is determined to proceed against this mighty creature, the chief prepares himself with great ceremony $\mathrm{he}$ is clothed in the sea-otter's skin, his body besmeared with oil and painted with red ochre; the canoes selected for the service are of a size between those used in war and the ordinary kind, and contain eighteen or twenty men, the bravest and most active that can be found. When the whale is discovered, the chief himself throws the first harpoon; but all the people in the various attendant canoes are armed with the same instrument, to be employed as occasion may require. As soon as the huge fish feels the smart of the first weapon, he dives, and carries the shaft with all its bladders along with him; on which the boats follow in his wake, and as he rises continue to fix their weapons till he finds it impossible to sink from the number of floating buoys attached to his body. The whale then drowns, and is towed on shore with great 
triumph and rejoicing. ${ }^{*} \mathrm{He}$ is immediately cut up, part being dedicated to the feast which concludes the day, and the remainder divided among those who shared the dangers and glory of the chase.

The ingenuity of the Nootka savages in many mechanical arts was very remarkable. Their manufacture of harpoons, lines, fish-hooks, bows and arrows, their skill in tanning and preparing furs, their ingenious manner of forging the metals procured from the English into various ornaments for their wives or favourites, and, above all, their art in constructing canves, astonished the European and Chinese artisans. Of the iron received in exchange for furs they made tools ; and it was seldom they could be prevailed on to use European utensils in preference to their own, with the exception of the saw, the utility of which in abridging labour was immediately perceived and made available. They formed of the same metal a species of tool for hollowing out large trees, which purpose it served far better than any instrument the carpenters of the Felice could give them. In this operation a flat stone was employed in place of an anvil, while a round one served for a hammer; and with these rude implements they shaped the red-hot iron into a tool resembling a cooper's adze, which they fastened to a wooden handle with cords made of sinews; it was then sharpened, and proved admirably adapted for the purposes for which it was intended. $\dagger$

After the English had been for some time in King George's Sound, the Americans began to make use of sails formed of mats, in imitation of Captain Meares's ship. Hannapa got the sailors to rig one of his war-canoes in the English style, of which he was extremely proud, never omitting the ceremony of hoisting his pendant whenever he approached, to the great amusement of the crew. Not long after this the English were waited upon by Wicananish, a prince of greater wealth and power than any they had yet seen, who invited them to visit his kingdom, which lay at some distance to the southward, that a commercial intercourse might be estabsished for the advantage of both parties. The invitation was accepted, and Wicananish himself met the Felice at some distance from the shore with a small fleet of canoes; and, coming on board, piloted them into the harbour. They 
found the capital to be at least three times the size of Nootka. The country round was covered with impenetrable woods of great extent, in which were trees of enormous size. After the king and his chiefs had been entertained on board, the English were in return invited to a feast by Wicananish; and it is not easy to conceive a more interesting picture of savage life than is given by Meares on this occasion. "On entering the house," says he, "we were absolutely astonished at the vast area it enclosed. It contained a large square, boarded up close on all sides to the height of twenty feet, with planks of an uncommon breadth and length. Three enormous trees, rudely carved and painted, formed the rafters, which were supported at the ends and in the middle by gigantic images, carved out of huge blocks of timber. The same kind of broad planks covered the whole, to keep out the rain; but they were so placed as to be removable at pleasure, either to receive the air and light or to let out the smoke. In the middle of this spacious ronm were several fires, and beside them large wooden vessels filled with fish-soup. Large slices of whale's flesh lay in a state of preparation, to be put into similar machines filled with water, into which the women, with a kind of tongs, conveyed hot stones from very fierce fires, in order to make it boil. Heaps of fish were strewed about; and in this central part of the square, which might properly be called the kitchen, stood large seal-skins filled with sll, from whence the guests were served with that delicious beverage. The trees that supported the roof were of a size which would render the mast of a first rate man-of-war diminutive on a comparison with them; indeed our curiosity as well as our astonishment was at its utmost stretch when we considered the strength which must have been required to raise these enormous beams to their present elevation, and how such strength could be commanded by a people wholly unacquainted, as we supposed, with the mechanic powers. The door by which we entered this extraordinary fabric was the mouth of one of these huge images, which, large as it may, from this circumstance, be supposed to have been, was not disproportioned to the other features of its colossal visage. We ascended by a few steps on the outside; and after passing the portal, descended down the chin into the house, where we found new matter for wonder in the number of men, $\mathrm{H} 2$ 
women, and children who composed the family of the chief, which consisted of at least 800 persons. These were divided into groups according to their respective ofices, which had distinct places assigned them. The whole of the interior of the building was surrounded by a bench, about two feet from the ground, on which the various inhabitants sat, ate, and slept. The chief appeared at the upper end of the room surrounded by natives of rank, on a small raised platform, round which were placed several large chests, over which hung bladders of oil, large slices of whale's flesh, and proportionable gobbets of blubber. Festoons of human sculls, arranged with some attention to uniformity, were disposed in almost every part where they could be placed; and, however ghastly such ornaments appeared to European eyes, they were evidently considered by the courtiers and people of Wicananish as a very splendid and appropriate decoration of the royal apartment." When the English appeared the guests had made a considerable advance in their banquet. Before each person was placed a large slice of boiled whale, which, with small wooden dishes filled with oil and fish-soup, and a muscle-shell instead of a spoon, composed the economy of the table. The servants busily replenished the dishes as they were emptied, and the women picked and opened some bark, which served the purpose of towels. The guests despatched their messes with astorishing rapidity and voracity, and even the children, some of them not above three years old, devoured the blubber and oil with a rapacity worthy of their fathers. Wicananish in the mean time did the honours with an air of hospitable yet dignified courtesy which might have graced a more cultivated society.

At the conclusion of the feast, it was intimated to the English that the proper time had arrived to produce their presents. Upon this a great variety of articles were displayed; among which were several blankets and two copper tea-kettles. On these last, considered to be alnost inestimable, the eyes of the whole assembly were instantly riveted ; and a guard was immediately mounted, who kept a jealous watch over them till curiosity was gratified; after which they were deposited in large chests rudely carved and fancifully adorned with human teeth. About fifty men now advanced into the middle of the apartment, each holding up 
a sea-otter skin nearly six feet in length, and while they remained in that position the prince delivered a speech, during which he gave his hand in token of friendship to the captain, and informing him that these skins were the return he proposed to malie for the present he had just received, concluded by ordering them to be immediately conveyed on board.

The English now opened a brisk trade, procuring the finest furs, while they were supplied with excellent provisions : salmon, cod, halibut, rock-fish, and herrings were brought to them fresh from the water; and the women and children sold them berries, wild onions, salads, and other esculent plants. Wicananish, however, was anxious to establish a rigid monopoly, and evinced the utmost jealousy lest any neighbouring princes should be admitted to trade with the English. None were allowed to go on board without his license; and one unfortunate stranger was detected without a passport, hurried into the woods, and, as was strongly suspected, instantly put to death. At last tivo chiefs, who had already entered into some transactions with Captain Meares, remonstrated against such illiberality ; and Wicananish, rather than go to war, concluded a treaty, which had the effect of restoring a good understanding by mutual sacrifices. Hanna and Detootche agreed to resign to Wicananish all the otter skins in their possession, on condition of receiving the two copper tea-kettles already mentioned. These last articles, however ludicrous it may appear in the eyes of European diplomatists; formed the grand basis of the treaty, and the terms of exchange were not arranged without much difficulty. During these proceedings the English had little opportunity to examine the country; but every thing which they saw was inviting. An archipelago extended from King George's Sound to the harbour of Wicananish, most of the islands being covered with wood, with few clear spots. The soil was rich, producing berries and fruits in abundance, and the timber of uncommon size and beauty, consisting chiefly of red oak, large cedar, black and white spruce-fir. In their expeditions inty the interior they met with frequent groves, where almoss every second tree was fit for masts of any dimensions.*

* Meares's Voyages, vol. i. p. 239. 
From Wicananish Captain Meares sailed southward along a coast not visited by Cook, of which the chart by Maurelle was so inaccurate that it seemed almost certain he had never surveyed it in person. During this voyage they were visited by a small fleet of canoes, filled with people far more savage than those hitherto met with. The face of the chief was bedaubed with black ochre, and powdered with a glittering sand, which communicated a singular fierceness of expression; while his manners were rude, and gave no encouragement to any more intimate intercourse. Meares continued his survey of the coast as far north as latitude $49^{\circ} 37^{\prime}$; after which he retraced his progress, and on reaching the Strait of Juan de Fuça took possession of it, with all the usual ceremonies, in the name of the King of Great Britain. The existence of this channel, which had been doubted since its discovery in 1592, was now positively ascertained, and the long-boat was despatched up the strait under the command of Mr. Duffin, first officer of the Felice. Her crew consisted of thirteen sailors, well armed, and provisioned for a month. In a week, however, they returned,-with their full complement indeed, sut every one of them wounded. They had been attacked by the natives with a ferocity and determination which set at naught the usual terror of firearms. The assailants used their bows and arrows, clubs, spears. stone-bludgeons, and slings, with great skill and courage. The boat itself showed this, being pierced in numerous places with the barbed arrows, many of which were still sticking in the awning, which, by intercepting the heavy showers of these missiles and breaking the fall of the large stones discharged from the slings, was the principal means of preserving the lives of the crew.

On returning down the strait, they were met by a canoe paddled by two subjects of Wicananish, and after purchasing some fish were about to bid them farewell, when the savages made them aware that they still had another commodity to dispose of, and to their inexpressible horror exhibited two human heads still dripping with blood. \&"They held up these detestable objects by the hair," says Meares, "with an air of triumph and exultation; and when the crew of the boat discovered signs of disgust and detestation at so appalling a spectacle, the savages, in a tone 
'and with looks of extreme satisfaction, informed them that they were the heads of two people belonging to Tatootche, the enemy of their own king Wicananish, whom they had 'recently slain."*

This last occurrence threw a gloom over the spirits of the ship's company, and caused them to make more minute inquiries into the habits of the savages, which brought to light some very extraordinary circumstances. Mild and amiable as were the general manners of the inhabitants of Nootka Snund, it was discovered by their own confession that they not only tortured captives with every refinement of cruelty, but feasted on human flesh. Callicum, a chief described by Meares as a model of kindness and even of delicacy in his intercourse with the English, acknowledged that he slept nightly on a pillow filled with human sculls, which he often exhibited as trophies of his valour. Maquilla betrayed his cannibal propensities in a manner still more decided: "It so happened that the chief, in ascending the side of the ship, by some untoward accident received a hurt in the leg. Orders were immediately given to the surgeon to attend, and when he was about to apply a plaster to the wound, Maquilla absolutely refused to submit, but sucked himself the blood which freely flowed from it; and when we expressed our astonishment and disgust at such conduct, he replied by licking his lips, patting his belly, and exclaiming, 'Cloosh, cloosh,' or 'Good, good!' Nor did he now hesitate to confess that he ate human flesh, and to express the delight he took in banqueting upon his fellow-creatures; not only avowing the practice, but informing the crew, as they stood shuddering at the story, that not long before this the ceremony of killing and eating a slave had taken place at Friendly Cove." $\dagger$ This acknowledgment was confirmed by Callicum and Hannapa, who, protesting they had never tasted the smallest bit of human flesh themselves, described Maquilla as peculiarly fond of it, and in the practice of killing a slave once a month to gratify his unnatural appetitc. Perhaps there might be some exaggeration in this ; but the ghastly ornaments of Wicananish's dining-room, the extraordinary pillow of Callicum, the exposure of men's heads and limbs 
for sale, and the admission of the chief himself, sufficiently prove the existence of this atrocious custom, whatever might be the extent to which it was carried.

For a long time the English thought the inhabitants had no religious belief whatever. To the huge misshapen images seen in their houses they addressed no homage; they had neither priests nor temples, nor did they offer any sacrifices; but an accidental circumstance led to the discovery that, though devoid of all superstitious observances, and wholly ignorant of the true God, they were not without a certain species of mythology, including the belief of an existence after death. "This discovery," says Meares, " arose from our inquiries on a very different subject: On expressing our wish to be informed by what means they became acquainted with copper, and why it was such a peculiar ohject of their admiration, a son of Hannapa, one of the Nootkan chiefs, a youth of uncommon sagacity, informed us of all he knew on the subject; and we found, to our surprise, that his story involved a little sketch of their religion." When words were wanting he supplied the deficiency by those expressive actions which nature or necessity seems to communicate to people whose language is imperfect; and the young Nootkan conveyed his ideas by signs so skilfully as to render them perfectly intelligible. He related his story in the following manner :- "He first placed a certain number of sticks on the ground, at small distances from each other, to which he gave separate names. Thus, he called the first his father, and the next his grandfather: he then took what remained and threw them all into confusion together, as much as to say that they were the general heap of his ancestors, whom he could not individually reckon. He then, pointing to this bundle, said, when they lived an old man entered the sound in a copper canoe, with copper paddles, and every thing else in his possession of the same metal; that he paddled along the shore, on which all the people were assembled to contemplate so strange a sight, and that, having thrown one of his copper paddles on shore, he himself landed. The extraordinary stranger then told the natives that he came from the sky, to which the boy pointed with his hand; that their country would one day be destroyed, when they would all be killed, and rise again to live in the place from 
whence he came. Our young interpreter explained this circumstance of his narrative by lying down as if he were dead, and then, rising up suddenly, he imitated the action as if he were soaring through the air. He continued to inform us that the people killed the old man and took his canoe, from which event they derived their fondness for copper, and he added that the images in their houses were intended to represent the form, and perpetuate the mission, of this supernatural person who came from the sky." *

As the objects of this voyage were principally of a commercial nature, Captain Meares had better opportunities to observe the character of the natives than to explore the coast or the interior of the country. The range of his navigation, extending only from Nootka Sound to the latitude of $49^{\circ} 37^{\prime}$ north, disclosed no regular continuity of land, but in every direction large islands, divided by deep sounds and channels. The time which this intelligent seaman could spare was not enough to complete the survey; but, judging from what he did see, he was led to the belief that the entire space from St. George's Sound to Hudson's Bay and Davis's Strait, instead of a continent, was occupied by an immense archipelago, through which might reach a passage frum the Pacific into the Atlantic Ocean. "The channels of this archipelago," says he, in his memoir on the probable existence of a north-west passage, "were found to be wide and capacious, with near two hundred fathoms' depth of water, and huge promontories stretching out into the sea, where whales and seaotters were seen in an incredible abundance. In some of these channels there are islands of ice, which we may venture to say could never have been formed on the western side of America, which possesses a mild and moderate climate; so that their existence cannot be reconciled to any other idea than that they received their formation in the eastern seas, and have been drifted by tides and currents through the passage for whose existence we are contending." +

To determine this great question, and complete an accurate survey of the north-west coast of America, Captain Vancouver, an excellent officer, who had received his pro-

* Mleares's Voyages, vol. ii. p. $70,71 . \quad †$ Ibid. vol. ii. p. 242 


\section{VOYAGES OF VANCOUVER AND KOTZEBUE.}

fessional education under Cook, was despatched in 1790 and, commencing his voyage at Cape Mendocino, in latio tude $41^{\circ}$, he sailed northivard two hundred and nineteen leagues to the Strait of Juan de Fuça, never losing sight of the surf which dashed against the shore, taling once or twice every day the meridional altitude, and minutely noting the position of the most conspicuous points. The whole coast presented an impenetrable barrier against approach from the sea, and no opening was found to afford his vessels the smallest shelter. $\mathrm{He}$ then explored the Strait of Juan de Fuça; and having satisfied himself that no passage across America was to be discovered there, devoted his time to the survey of the labyrinth of islands, sounds, and inlets between $50^{\circ}$ and $60^{\circ}$ of latitude. After a series of patient and scientific observations every way worthy of the school in which he had been bred, he ascertained the grand fact that the coast was throughout continuous, and thus dispelled all hope of a north-west passage in this quarter. It was his fate to encounter not a little unreasonable skepticism when the result was made public ; and, like many other travellers and navigators, he found too much reason to complain of those lazy closet-philosophers who refuse to admit any testimony which happens to contradict their own preconceived theories. Time, however, has done him justice, and fully confirmed the accuracy of his report.

After the disastrous result of the expedition of Behring, more than eighty years elapsed before Russia thought proper to pursue the career of discovery on the extreme coasts of North-western America. At length Count Romanzoff, a scientific and patriotic nobleman, determined to despatch Lieutenant Kotzebue on a voyage to the straits which bear the name of that great mariner. His equipment consisted of a single vessel, the Rurick, one hundred tons burden, with twenty-two sailors, a surgeon, and a hotanist. Having doubled Cape Horn, he arrived on the 19th June, 1816, at Awatscha. Continuing his course, he passed the boundary explored by Behring, and on the 1st of August descried on his right, in latitude $68^{\circ}$, a broad opening which he trusted would prove the long-sought-for passage. Having entered, he landed on the beach, ascended a neighbouring hill, and saw nothing but water as far as the eye could reach. Full 
of ardent expectation he employed a fortnight in examining this sound, making a complete circuit of its shores. No outlet, however, was discovered, except one, which it appeared almost certain communicated with Norton Sound, and Kotzebue resumed his voyage, which, however, was attended with no new or important results. To this arm of the sea, the discovery of which forms the principal feature in his enterprise, he has very properly communicated his name.

With Kotzebue terminates our account of the progress of discovery upon the north-ivestern shores of America; for an outline of the survey made by Captain Beechey belongs to a future portion of this disquisition. It is a pleasing reflection, that almost exclusively to the British navy belongs the hard-earned praise of having explored nearly the whole of this coast, with an accuracy which leaves nothing to be desired by the most scientific navigator.

\section{CHAPTER III.}

\section{Hearne and Sir Alexander Mackenzie.}

Colonization of Canada-French Fur-trade-Rise of Hudson's Bay Company-Hearne's Three Journeys--North-west Fur Company-First Journey of Sir Alexander Mackenzie in 1789--His Second Expedition in 1792 .

Havivg completed a brief sketch of the progress of discovery along the wide extent of the eastern and western shores of North America, from the first expedition of Cabot to the latest attempts of Kotzebue, two important subjects present themselves, - the rise of the fur-trade, and the great discoveries which were achieved by British subjects connected with this branch of commercial enterprise. The expedition of Cartier conferred on the French that title to the countries round the St. Lawrence which results from priority of discovery; and other circumstances combined to direct their efforts chiefly to the colonization of the more northern tracts of America. Among these causes may be 
reckoned the disastrous failure of their attempt to erablish a settlement in Florida, the great power of the Spaniards in that quarter, and the preoccupation of the middle regions of the continent by the English. In 1598, the Sieur de la Roche, a Breton gentleman of ancient family, obtained from Henry IV. a patent, equally unlimited with that granted by Elizabeth to Gilbert and Raleigh. He was nominated lieutenant-general of Canada, Hochelaga, Newfoundland, Labrador, and of the countries lying on the river of the great Bay of Norimbega (meaning the St. Lawrence), and the supreme command, both civil and military, was concentrated in his single person. His preparations were singularly disproportionate to those high-sounding titles, and the whole expedition was unfortunate. La Roche, with a small squadron, and crews consisting principally of convicted felons, landed on Sable Island, near the coast of Nova Scotia. From this barren spot, ill adapied for a settlement, he reached the opposite shore, which he surveyed; and having intrusted the temporary command of the colony to an inferior officer, he returned to France to procure additional supplies. On arriving in Brittany, a dispute arose between him and the Duke de Mercœur, a nobleman enjoying the confidence of the French monarch, by whose influence the royal favour was wholly withdrawn from $\mathrm{La}$ Roche. That adventurer, deprived of all means of prosecuting his enterprise in the New World, soon after died of a broken heart.

Meantime the colony on Sable Island were exposed to famine and disease, and totally neglected by the king, amid the occupation and excitement of his vast political schemes. Their existence was at length accidentally recalled to the mind of Henry, who in deep remorse for his forgetfulness despatched a vessel, which on its arrival found only twelve survivors. They had formed a hovel of the planks of a shipwrecked Spanish vessel, supported themselves by fishing, and replaced their worn-out European garments with the skins of the sea-wolf. On their return to France, the monarch was greatly moved by the account of their sufferings, corroborated as it was by their emaciated and haggard aspect, matted hair, beards which almost swept the ground, and singular dress. He hastened to compensate for his 
neglect, by granting to such as were felons a free pardon, and presenting to each a sum of fifty crowns. *

These disasters were followed soon after by an attempt of Chauvin and Pontgrave, two fur-merchants, to establish a colony at Tadoussack, on the mouth of the Saguenay, which proved abortive, and gave place to an expedition on a more enlarged scale, planned and conducted by De Monts, a gentleman of Saintonge, whose squadron consisted of forty vessels. His first settlement was on the Island of St. Croix, from which he removed to Port Royal, now known by the name of Annapolis, where he appears to have abandoned his more pacific designs for the superior excitation and profits of piracy. The complaints of the merchants engaged in the Newfoundland fishery terminated in the recall and disgrace of De Monts; but Champlain, on whom the command devolved, showed himself every way worthy of the trust. From Tadoussack he removed the principal settlement to Quebec, where he built and fortified a town, reduced the surrounding territory into cultivation, and became the founder of the government of Canada, or NewFrance. Leaving his infant settlement, he next determined to penetrate into the interior; and his emotions of wonder and astonishment may be easily conceived, when, ascending the St. Lawrence, the majestic forests of Canada first met his eye, encircling in their bosom the greatest lakes known to exist in the world. Surveying first the southern bank of the river, and of the lakes Ontario and Erie, he found that he had reached the very cradle of savage life, surrounded by nations whose manners, occupations, and superstitions were as new as they were bold and terrific.

To pursue the discoveries of the French into the interior of North America does not properly fall within the limits of this work; and it is sufficient at present to observe, that after a long and sanguinary struggle between the armies of France and England, in the war which broke out in 1756, Canada was at last subdued by the English, and the possession of the province confirmed to Great Britain by the treaty of 1763. During the war between the United States and the mother country, Upper Canada once more became the theatre of an obstinate contest, which concluded, how-

* Histoire Général des Voyages, vol. xiv. p. 589, 591. 
ever, unfavourably for the American troops ; and the country has since remained an integral part of the British dominions. Under the French the fur-trade, notwithstanding the restrictions with which commerce was oppressed, was carried to a great height and embraced an immense extent of cuuntry. It was conducted by a set of hardy adventurers, who joined the savages in their hunting-parties, and thus collected large cargoes of furs with which they supplied the merchants. Their distant inland expeditions sometimes occupied twelve or even eighteen months; and during this period their uninterrupted familiarity with the natives almost transformed them into as wild and barbarous a condition as that of the tribes with whom they associated. "It requires less time," says Sir Alexander Mackenzie, "for a civilized people to deviate into the manners and customs of savage life, than for saragrs to rise into a state of civilization. Such was the event with those who thus accompanied the natives on their hunting and trading excursions; for they became so attached to the Indian mode of life, that they lost all relish for their former habiis and native homes. Hence they derived the title of Coureurs de Bois, became a kind of pedlars, and were extremely useful to the merchants engaged in the fur-trade, who gave them the necessary credit to proceed on their commercial undertakings. Three or four of these people would join their stock, put their property into a birch-bark canoe which they worked themselves, and would then either accompany the natives in their excursions, or penetrate at once into the country. At length these voyages extended to twelve or fifteen months, when they returned with rich cargoes of furs, and followed by great numbers of the natives. During the short time requisite to settle their accounts with the merchants and procure fresh credit, they generally contrived to squander away all their gains, when they returned to renew their favourite mode of life, their views being answered and their labour sufficiently rewarded by indulging themselves in extravagance and dissipation during the short space of one month in twelve or fifteen. This indifference about amassing property, and the pleasure of living free from all restraint, soon brought on a licentiousness of manners which could not long escape the vigilant observation of the missionaries, who had much reason to complain of their being a disgrace 
to the Christian religion, by not only swerving from its duties themselves, but bringing it into disrepute with those of the natives who had become converts to it, and consequently obstructing the great object to which these pious men had devoted their lives. They therefore exerted their influence to procure the suppression of these people; and accordingly no one was allowed to go up the country to traffic with the Indians without a license from the French government." This change of system was not at first attended with the expected benefits; for the licenses were sold in most instances to retired officers or their widows, who again disposed of them to the fur-merchants, and they of necessity recalled to their service the coureurs de bois as their agents : thus matters assumed, though by a somewhat more circuitous process, the same aspect as before. At last military posts were established at the confluence of the great lakes, which repressed the excesses of the woodrunners, and afforded protection to the trade; while under this new system, a body of respectable men, usually retired officers, introduced order and regularity in the traffic with the natives, co-operated with the efforts of the missionaries, and extended their intercourse with the various tribes to the distance of two thousand five hundred miles, from the most civilized portion of the colony to the banks of the Saskatchewine river in $53^{\circ}$ north latitude, and longitude $102^{\circ}$ west. $\dagger$ Of these trading commanders two individuals attempted to penetrate to the Pacific Ocean, but appear to have been unsuccessful.

The discoveries of the English in Hudson's Bay, and the latest attempts of Fox and James to reach the Pacific through some of its unexplored channels, have been sufficiently enlarged upon in a former volume; $\ddagger$ but though unsuccessful in their great design, the accounts brought home regarding the rich furs of these extreme northern shores excited the attention of Grosseliez, an enterprising individual, who undertook a voyage to survey the cowintry, and laid before the French government a proposal for a commercial

* Sir Alexander Mackenzie's History of the Fur-trade, prefixed to his Woyages, p. 1-3.

† Ibid.p. 6.

$\$$ Yolar Seas and Regions, chap. vi. 
settlement upon the coast. The minister, however, re. jected it as visionary; and Grosseliez, having obtained an introduction to Mr. Montagu, the English resident at Paris, was introduced to Prince Rupert, who, struck by the probable advantages of the project, eagerly patronised it. By his interest with the English king he obtained the grant of a ship commanded by Captain Zachariah Gillam, who sailed with Grosseliez in 1668, and penetrating to the top of James's Bay, erected Fort Charles on the bank of the Rupert River. In the succeeding year Prince Rupert, with seventeen other persons, were incorporated into a company, and obtained an exclusive right to establish settlements and carry on trade in Hudson's Bay. Their charter recites, that those adventurers having at their own great cost undertaken an expedition to Hudson's Bay, in order to discover a new passage into the South Sea, and to find a trade for furs, minerals, and other commodities, and having made such discoveries as encouraged them to proceed in their design, his majesty granted to them and their heirs, under the name of "The Governor and Company of Adventurers frading into Hudson's Bay," the power of holding and alienating lands, and the sole right of trade in Hudson's Strait, and with the territories upon the coasts of the same. They were authorized to fit out ships of war, to erect forts, make reprisals, and send home all English subjects entering the bay without their license, and to declare war and make peace with any prince or people not Christian.*

Instituted with such ample powers, and at first placed under the management of enlightened men, this company soon arrived at considerable prosperity. They have, indeed, been severely censured as exhibiting little zeal to promote discovery, and for uniformly opposing every attempt on the part of their servants to solve the long-agitated question of a north-west passage. There appears to have been much personal pique in these accusations; and the expedition of Knight, in 1721, fitted out on the most liberal scale at the company's expense, and the tenor of their original instructions to their governor, certainly prove that they were not enemies to the cause of discovery; while the failure of the

* Macpherson's Annals of Commerce, vol. ii. p. 555, 556. 
voyages of Miduleton in 1742, and of Captains Moore and Smith in 1746, must at length have convinced the bitterest opponents of the company, that if they had not discovered the long-expected passage in some of the straits leading into Hudson's Bay, it was for the very sufficient reason that such did not exist. But the most remarkable refutation of these allegations is to be found in the important and interesting journey of Hearne, from Prince of Wales' Fort to the Northern Ocean, brought to a successful termination in 1772 , which, in its origin and progress, merits our particular attention.

The native Indians, who range over rather than inhabit the large tract of country north of Churchill River, having repeatedly brought specimens of copper ore to the company's factory, it was plausibly conjectured that these had been found not far from the British settlements; and as the savages affirmed that the mines were not very distant from a large river, it was imagined, most erroneously, as was proved by the result, that this stream must empty itself into Hudson's Bay. In 1768, the Indians who came to trade at Prince of Wales' Fort brought further accounts of this river, exhibiting at the same time samples of copper, which they affirmed to be the produce of a mine in its vicinity. The governor now resolved to despatch an intelligent person across the continent to obtain more precise information. Samuel Hearne was chosen for this service, a man of great hardihood and sagacity, bred in the employment of the company, and who, without pretensions to high scientific attainments, possessed sufficient knowledge to enable him to construct a chart of the country through which he travelled. His instructions directed him to proceed to the borders of the country of the Athibasca Indians, where it was expected he would meet with a river represented by the Indians to abound with copper ore, and to be so far to the north that in the middle of summer the sun did not set. It was called by the natives Neetha-sansan Dazey, or the Far-off Metal River; and Mr. Hearne was directed to explore its course to the mouth, where he was to determine the latitude and longitude, to ascertain whether it was navigable, and to judge of the practicability of a settlement. He was enjoined also to examine the mines alleged to exist in that district, the nature of the 
soil and its productions, and to make every inquiry and observation towards discovering the north-west passage.*

On the 6th of November, 1769, he set out from Prince of Wales' Fort, Hudson's Bay, upon this perilous journey. He was accompanied by two Englishmen only,-Ilbester a sailor, and Merriman, a landsman ; by two of the Homeguard Southern Indians, - a name given to those natives residing as servants on the company's plantation, and employed in hunting; and by eight Northern Indians, under the command of Captain Chawchinahaw and Lieutenant Nabyah. He was provided with ammunition for two years, some necessary iron implements, a few knives, tobacco, and other useful articles. As to his personal outfit, his stock consisted simply of the shirt and clothes he wore, one spare coat, a pair of drawers, as much cloth as would make two or three pairs of Indian stockings, and a blanket for his bed. "The nature of travelling long journeys," he observes, "in these countries will not admit of carrying even the most common article of clothing; so that the traveller is obliged to depend on the district he traverses for his dress as well as his sustenance." The baseness and treachery of the Indians, however, soon put a period to the first journey, and the desertion of Chawchinahaw with his whole escort rendered it absolutely necessary fer the little party to make the best of their way back to the fort, where they arrived on the 8th of December, after penetrating only two hundred miles into the interior.

It was now determined to resume the expedition with greater precautions against failure. The Indian women who accompanied their husbands in the first journey were left behind, as were the two Englishmen, who had been of nttle service; and instead of the treacherous Chawchinahaw, Hearne selected an Indian named Connequeesee, who affirmed he was acquainted with the country, having once been near the river, the discovery of which formed one great object of the journey. Attended by this man, along with three Northern Indians and two of the Homeguard natives, the traveller once more set out, on the $23 \mathrm{~d}$ February, while the snow was so deep on the top of the zamparts of the fort that few of the cannon could be seen.

*Hearne's Journey, Introduction, p. 40. 
After undergoing the severest extremities from hunger and fatigue, Mr. He:rne reached in August the river Doobaunt, in latitude $63^{\circ} 10^{\prime}$ north. 'The progress thus far, however, had been painful beyond measure, owing to the difficulty of pushing forward through a wild unexplored country, intersected with rivers, lakes, and woods, at the outset thickly covered with snow; and on the approach of the warmer months so flooded and marshy as to render travelling on foot inexpressibly fatiguing. To add to this, the voracity, improvidence, and indolence of the Indians subjected the party to repeated distress. If from fishing or hunting a larger supply than usual was procured, instead of using it with moderation, and laying up a store for future necessities, all was devoured by the savages, who, like the boa after he has gorged his prey, coiled themselves up, and remained in a state of sleepy torpor till the call of hunger again roused them to activity.

At first the party subsisted without difficulty on the fish which abounded in the lakes and rivers; but in the beginning of April they entirely disappeared ; and as the "goose season," or period when the geese, swans, ducks, and other migratory birds resort to these latitudes was yet distant, they began to suffer grievnisly from want of provisions. Oecasionally they were relieved by killing a. few deer or musk-oxen; but the ground and the brushwood were so saturated with moisture from the melting of the snow, that to kindle a fire was impossible ; with their clothes drenched in rain, and their spirits depressed, they were compelled to eat their meat raw,-a necessity grievous at all times, but in the case of the flesh of the musk-ox, which is rank, tough, and strongly impregnated with the sickening substance from which it derives its name, peculiarly repulsive and unwholesome.*

The simple and modest manner in which these severe sufferings are described by Hearne is peculiarly striking. "To record," says he, "in detail each day's fare since the commencement of this journey would be little more than a dull repetition of the same occurrences. A sufficient idea of it may be given in a few words, by observing, that it may justly be said to have been either all feasting or all 
famine; sometimes we had too much, seldom just enough, frequently too little, and often none at all. It will be only necessary to say, that we fasted many times two whole days and nights, twice upwards of three days, and once, while at Shenanhee, near seven days, during which we tasted not a mouthful of any thing, except a few cranberries, water, scraps of old leather, and burnt bones." On these pressing occasions Hearne often saw the Indians examine their wardrobe, which consisted chiefly of skin clothing, considering attentively what part could best be spared, when sometimes a piece of half-rotten deer-skin, and at others a pair of old shoes, would be sacrificed to alleviate extreme hunger. "None of our natural wants," ne observes, "if we except thirst, are so distressing or hard to endure as hunger, and in wandering situations like that which I now experienced, the hardship is greatly aggravated by the uncertainty with regard to its duration, and the means most proper to be used to remove it, as well as by the labour and fatigue we must necessarily undergo for that purpose, and the disappointments which too frequently frustrated our best-concerted plans and most strenuous exertions. It not only enfeebles the body, but depresses the spirits, $i$, spite of every effort to prevent it. Besides which, for want of action, the stomach so far loses its digestive powers, that, after long fasting, it resumes its office with pain and reluctance. During this journey I have too frequently experienced the dreadful effects of this calamity, and more than once beeu reduced to so low a state by hunger and fatigue, that when Providence threw anv thing in my way, my stomach has been scarcely able tc retain more than two or three ounces without producing tne most oppressive pain."*

On the 30th June, they arrived at a small river called Cathawhachaga, which empties itself into White Snow Lake, in $64^{\circ}$ north latitude. Here, as the guide declared they could not that summer reach the Coppermine River, Hearne determined to pass the winter, with the intention of pushing on to his destination in 1771. They accordmgly forsook their northward route, and taking a westerly courae were joined in a few days by many troops of wan- 
dering Indians; so that by the 30th July they mustered about seventy tents, containing nearly six hundred souls, and on moving in the morning the whole ground seemed alive with men, women, children, and dogs. The deer were so plenty that, though lately five or six individuals had almost perished from hunger, this numerous body supported themselves with great ease, and often killed their game for the skins, leaving the carcass to be devoured by. the foxes.* In this manner, engaged alternately in hunting and fishing, making observations on the country, and studying the extraordinary manners of his associates, the English traveller was preparing for his winter sojourn, when an accident rendered his quadrant useless, and compelled him, on 13th August, to set out on his return to the fort.

The hardships he endured on his route homeward were various and accumulated. He was plundered by the northern Indians, who, adding insult to injury, entered his tent, smoked a pipe which they filled with the white man's tobacco, asked to see his luggage, and without waiting for an answer turned the bag inside out, and spread every article on the ground. The work of appropriation was equally rapid, and the empty bag was flung to the owner; but a fit of compunction seizing them, they restored a knife, an awl, and a needle. On begging hard for his razors, they consented to give up one, and added enough of soap to shave him during the remainder of his journey, making him understand that the surrender of these articles called for his warmest gratitude.

As the cold weather approached, the party thus plundered suffered grievously from want of that warm deerskin clothing used by the Indians at this season. A dress of this kind is rather costly, requiring the prime parts of from eight to eleven skins. These Hearne at last managed to collect; but as the Indian women alone could prepare them, he was compelled to carry this load along with him from day to day, earnestly begging the natives at each successive resting-place to permit their wives to dress his skins. He met, however, with a surly and uniform refusal; and at last, after bearing the burden for several weeks, was

* Llearne's Journey, p. 40. 
forced to throw it off, and sustain the cold as he best could, without either skin-clothing or snow-shoes. When, continuing their course in this forlorn condition to the southeast, they met with Captain Matonabibee, a powerful and intelligent chief, who was then on his way to Prince of Wales' Fort with furs and other articles of trade. It was this person who brought the accounts of the Coppermine River, which induced the company to fit out the expedition, and he was naturally interested in its success. He evinced the utmost activity in relieving their wants, furnished them with a warm suit of otter and other skins, and, not being able to provide them with snow-shoes, directed them to a small range of woods, where they found materials for both shoes and sledges. Matonabbee then treated the party to a feast, and took occasion in his conversation with Hearne to explain the causes of his failure, and to offer his assistance in a third expedition. He attributed all their misfortunes to the misconduct of the guide, and to their having no women with them. "In an expedition of this kind," said he, "when all the men are so heavily laden that they can neither hunt nor travel to any considerable distance, in case they meet with success in hunting, who is to carry the produce of their labour? Women were made for labour ; one of them can carry or hatil as much as two men can do. They also pitch our tents, make and mend our clothing, keep us warm at night; and in fact there is no such thing as travelling any considerable distance, or for any length of time, in this country, without them; and yet, though they do every thing, they are maintained at a trifling expense; for, as they always act the cook, the very licking of their fingers in scarce times is sufficient for their subsistence."* Assisted by this friendly chief, the English traveller again set forward, and after experiencing an intense degree of cold, by which the favourite dog in his sledge was frozen to death, he reached the fort on 25th November, having been absent eight months and twentytwo days. Matonabbee arrived a few days after.

Though twice compelled to return, Hearne, whose spirit was not to be overcome by fatigue or disappointment, offered his services to proceed on a third journey, which was 
uitimately crowned with success. For this he engaged Matonabbee as guide, and declined taking any Home-guard Indians. Their place, however, was occupied, according to the principles already laid down, by seven of Matonabbee's wives, who, by the assistance they afforded, did no disparagement to the singular picture of female activity which he had drawn. They set out on the 7th of December, and notwithstanding frequent privations, want of food, and intense cold, their sufferings were not so aggravated as in the former attempts. The country through which they passed towards the west was wild and barren, occasionally covered with thick shrubby woods of stunted pine and dwarf juniper, studded with frequent lakes and swamps, whose sides were fringed with willows. Through this ground they travelled in high spirits, but on rather short comrinons, orving to the scarcity of deer, and the improvidence of the Indians, who consumed every thing in the store during the first days of their march, trusting to find a stock of provisions which they had hid in a certain spot on their way to the fort. On reaching the place, however, they discovered that the provisions had been carried off; and the equanimity with which the Indians bore the disappointment, and travelled forward under the conjoined miseries of hunger and fatigue, was very striking. At last they succeeded in killing a few deer, and halted to take some refreshment. For a whole day they never ceased eating, and an additional repast on two large buck-deer, which they killed a few days after, at last fairly overcaine Captain Matonabbee, who, after devouring at one sitting as much as would have satisfied six moderate men, seemed somewhat unreasonably astonished to find himself indisposed.

Having recovered from the effects of this surfeit, they proceeded from Island Lake towards the main branch of the Cathawhachaga, which they crossed, and directing their course lyy Partridge Lake and Snow Bird Lake, arrived on the $2 \mathrm{~d}$ March at a large tent of Northern Indians, not far from the Doobaunt Whoie River. Although these people had remained in the same spot since the beginning of winter, they found a plentiful subsistence by catching deer in a pound. Their mode of accomplishing this is to select a well-frequented deer-path, and enclose with a strong fence of twisted trees and brushwood a space about a mile in cir- 
cumference, and sometimes more. The ertrance of the pound is not larger than a common gate, and its inside is crowded with innumerable small hedges, in the openings of which are fixed snares of strong well-twisted thongs. One end is generally fastened to a growing tree; and as all the wood and jungle within the enclosure is left standing, its interior forms a complete labyrinth. On each side of the door, a line of small trees, stuck up in the snow fifteen or twenty yards apart, form two sides of an acute angle, widening gradually from the entrance, from which they sometimes extend two or three miles. Between these rows of brushwood runs the path frequented by the deer. When all things are prepared, the Indians take their station on some eminence commanding a prospect of this path, and the moment any deer are seen going that way, the whole encampment, men, women, and children, steal under cover of the woods till they get behind them. They then show themselves in the open ground, and, drawing up in the form of a crescent, advance with shouts. The deer, finding themselves pursued, and at the same time inagining the rows of brushy poles to be people stationed to prevent their passing on either side, run straight forward till they get into the pound. The Indians instantly close in, block up the entrance, and while the women and children run round the outside to prevent them from breaking or leaping the fence, the men enter with their spears and bows, and speedily despatch such as are caught in the snares or are running loose.*

On the 8th of April, they reached an island in a small lake named Thelewey-aza-weth, and pitched their tent ; and as the deer were numerous, and the party, which had been joined by various wandering Indians, now amounted to seventy persons, they letermined to remain for some time, and make preparations for their enterprise in the ensuing summer. They were busily employed during their intervals from hunting, in providing staves of birch about one and a quarter inch square and seven or eight feet long, which served for tent-poles all the summer, and were converted into snow-shoes in winter. Birch-rind, with timbers and other wood for canoes, formed also objects of attention; and as Clowey, the place fixed upon for building their sa.

- Hearne's Journes, p 78-80. 
noes, was still many miles distant, all the wood was reduced to its proper size to make it light for carriage. At this place Matonabbee solaced himself by purchasing from some Northern Indians another wife, who fur size and sinews might have shamed a grenadier. "Take them in a body," says Hearne, "and the Indian women are as destitute of real beauty as those of any nation I ever saw, although there are some few of them when young who are tolerable; but the care of a family, added to their constant hard labour, soon make the most beautiful among them look old and wrinkled, even before they are thirty, and several of the more ordinary ones at that age are perfect antidotes to the tender passion. Ask a Northern Indian What is beauty? he will answer, A broad flat face, small eyes, high cheekbones, three or four broad black lines across each cheek, a low forehead, a large broad chin, a hook nose, and a tawny hide. These heauties are greatly heightened, or at least renderer more valuable, if the possessor is capable of dressing all kinds of skins, and able to carry eight or ten stone in summer, and to haul a far greater weight in winter. Such and similar accomplishments are all that are sought after or expected in an Indian Northern woman. As to their temper, it is of little consequence; for the men have a wonderful facility in making the most stubborn comply with as much alacrity as could he expected from those of the milciest and most obliging turn of mind." "*

Before starting from this station, Matonabbee took the precaution of sending in advance a small party with the wood and birch-rind; they were directed to press forward to Clowey, a lake near the barren ground, and there build the boat, to be ready upon their arrival. When the journey was about to be resumed, one of the women was taken in labour. The moment the poor creature was delivered, "which," says Hearne, "was not till she haủ suffered a severe labour of fifty-two hours," the signal was made for setting forward; the mother took her infant on her back, and walked with the rest; and though another person had the humanity to haul her sledge for one day only, she was obiiged to carry a considerable load in addition to her little one, and was compelled frequently to wade knee-deep in

* Hearne's Journey, p. 89, 90. 
water and wet snow. Amid all this, her looks, pale and emaciated, and the moans which burst from her, sufficiently proved the intolerable pain she endured, but produced no effect upon the hard hearts of her husband and his companions. When an Indian woman is taken in labour, a small tent is erected for her, at such a distance from the encampment that her cries cannot be heard, and the other women are her attendants, no male except children in arms ever offering to approach; and even in the most critical cases no assistance is ever given,-a conduct arising from the opinion that nature is sufficient to perform all that is necessary. When Hearne informed them of the assistance derived by European women from the skill and attention of regular practitioners, their answer was ironical and characteristic. "No doubt," said they, "the many hump-backs, bandy-legs, and other deformities so common among you English are owing to the great skill of the persons who assisted in bringing them into the world, and to the extraordinary care of their nurses afterward." *

In eleven days they travelled a distance of eighty-five miles, and on the $3 \mathrm{~d}$ May arrived at Clowey, where they were joined by some strange Indians, and commenced the important business of building their canoes. The party sent ahead for this purpose arrived only two days before, and had made no progress in joining the timbers they had carried along with them. The whole tools used by an Indian in this operation, in making snow-shoes and all other kinds of wood-work, are a hatchet, a knife, a file, and an awl; but in the use of these they are very dexterous. In shape, their cannes bear some resemblance to a weaver's shuttle, having flat bottoms, with straight upright sides, and sharp at each end. The stern is the widest part, being constructed for the reception of the baggage ; and occasionally it admits a second person, who lies at full length in the bottom of the little vessel, which seldom exceeds twelve or thirteen feet in length, and about twenty inches or two feet in breadth at the widest part. The forepart is unnecessarily long and narrow, and covered with birch-bark, which adds to the weight without contributing to the burden of the canoe. The Indians, for the most part, employ a singlo

* Hearne's Journey, p. 93. 
paddle ; double ones, like those of the Esquimaux, are seldom used unless by hunters, who lie in ambush for the purpose of killing deer as they cross rivers and narrow lakes. Upon the whole, their vessels, though formed of the same materials as those of the Southern Indians, are much smaller and lighter; and, from the extreme simplicity of build, are the best that could be contrived for the necessities of these poor savages, who are frequently obliged to carry them upon their back 100 and sometimes 150 miles, without having occasion to launch them.

At Clowey the expedition was joined by nearly 200 Indians from various quarters, most of whom built canoes there; and on the 23d May, Mr. Hearne and Matonabbee, whose character and consequence effectually protected the white man from plunder, proceeded northward. For some time they met with no distresses, except those occasioned by the intense cold, which had been preceded by thunderstorms and torrents of rain. Misfortune, however, now attacked Matonabbee on the tender side of his eight wives, the handsomest of whom eloped in the night, accompanied by another woman. Both having been carried off by force, it was suspected they had fled to the eastward with the plan of rejoining their former husbands. Scarce had the savage polygamist recovered from this blow, when he experienced a fresh mortification : an Indian of great strength, from whom Matonabbee a short time be fore had purchased a stout, and therefore valuable, wife, insisted on taking her back, unless he instantly surrendered a certain quantity of ammunition, a kettle, some pieces of iron, and other articles. The hardship of this case arose from an extraordinary custom, by which the men are permitted to wrestle for any woman to whom they are attached, the victorious party carrying off the prize. It is for this reason that the greatest emulation prevails in all athletic exercises among the young Indians; and the children are perpetually seen trying their powers in wrestling, under the idea that this is the education which will chiefly benefit them when they grow up. A weak man seldom long retains a wife whose services another wants; for when the helpinates of an able-bodied savage are too heavily laden with furs or provisions, he makes no scruple of seizing the spouse of his weaker neighbour, and transferring part of the burden to her back; while, if the injured party can 
not challenge the aggressor to a wrestling-match, he must not otherwise complain. The distress, therefore, of Matonabbee upon this occasion may be easily accounted for, as he was wounded in his pride and in his property, if not in his affections. But a personal contest was out of the question, and he was obliged to purchase his favourite over again, by yielding up all that was demanded by his antagonist. This affair had nearly proved a serious obstacle to the expedition; for so bitterly did the chief resent the affront, entertaining the highest ideas of his personal consequence, that he had resolved, like a Coriolanus of the New World, to renounce all further alliance with his countrymen, and join the Athabasca Indians, among whom he had formerly resided. But Hearne strenuously opposed this project, and at last succeeded in dissuading him from it.*

Having agreed to proceed, Matonabbee, for the better prosecution of the enterprise, determined to make some new arrangements: he selected his two youngest wives, who were unencumbered with children, as alone worthy to accompany him, while the remainder, with all their luggage and a considerable number of the men, were commanded to await the return of the party from the Coppermine River. This change of plan, however, was not carried through without difficulty. When the hour of separation came, and Matonabbee and Hearne set out in the evening of 31st May, a low murmur of lamentation proceeded from the tents of the women who were left behind, which, running through all the notes of increasing grief, at last burst into a loud yell. This continued as long as the party were in sight; nor was it without much angry expostulation that some of them were prevented from following their husbands. The Indians, however, regarded all this, which deeply affected their European associate, with indifference, walking forward without casting behind them a single look or word of sympathy, and joyfully congratulating themselves on getting rid of the women, dugs, children, and other encumbrances, which added so greatly to the toil of the journey. One article they all carried, although to Hearne it appeared unnecessary, considering the expedition to be pacific, - this was target of thin boards two feet broad and about three feet 
long. On inquiring for what purpose these shields were to be used, he discovered that the main consideration which reconciled the Indians to this expedition was the hope of attacking and murdering the Esquimaux who frequented the Coppermine River, between whom and the other Indian tribes there had long existed a deadly enmity. All the arguments employed by Hearne were insufficient to dissuade them from these hostile intentions.

The party, having crossed the arctic circle, arrived at Cogead Lake, which they found frozen over; so that they traversed its creeks and bays without the aid of their canoes. Thence they directed their course due north till they met with a branch of the Congecathawhachaga River, where some Copper Indians received them with great kindness, and readily sent all their canoes to their assistance,-a picee of courtesy particularly seasonable, as the ice had now broken up. To these Indians Hearne explained the object of his journey, and his guide being personally known to them, they treated the party, which consisted of 150 persons, with distinguished honour; a feast was given, the English traveller smoked with them his calumet of peace, and their chiefs expressed the greatest anxiety that a European settlement should be established in the neighbourhood of the Copperminc River. They acknowledged they had never found the sea at the mouth of the river free from ice; but with singular simplicity seemed to consider this a very trifling objection, observing, that the water was always so smooth between the ice and the shore, that even small boats could sail there with great ease; and inferring that what a canoe could do a large ship must be sure to accomplish. As Hearne was the first white man they had seen, he was surrounded by numbers, who examined him with the utmost minuteness. The result, however, was satisfactory ; for they at last pronounced him to be a perfect human being, except in the colour of his hair and eyes: the first they insisted was like the stained hair of a buffalo's tail, and the last, being light, were compared to those of a gull. The whiteness of his skin also was a circumstance on which they demurred a little, observing, that it looked like meat which had been sodden in water till all the blood was extracted. He continued, however, to be viewed with a mixture of curiosity and admiration, and at his toilet was 
generally attended by a body of the Indians, who, when he used his comb, asked for the hairs which came off. These they carefully wrapped up, saying, "When I see you again, you shall again see your hair." *

On reaching Congecathawhachaga in latitude $68^{\circ} 46^{\prime}$ north, Matonabbee deemed it expedient to leave all the women, taking the precaution to kill as many deer as were necessary for their support during his absence. The flesh was cut into thin slices and dried in the sun,-a frequent mode of preserving it in these high northern latitudes, by which it is kept palatable and nourishing for a twelvemonth. Having completed these arrangements, the party resumed their journey on the 1 st of July, proceeding amid dreadful storms of snow and occasional torrents of rain, which drenched them to the skin, through a barren and desolate country, where it was impossible with the wet moss and green brushwood to kindle a fire. Compelled to take shelter in caves at night,-for they had no tents, obliged to eat their meat raw, with the enjoyment of no higher luxury than a pipe, they yet pushed forward with unshaken perseverance, and after a week of great suffering hat the comfort to observe a complete change in the weather, which first became moderate, and soon after so sultry that it was sometimes impossible to move at all.

Early on the moming of 13 th July, the expedition crossed a long chain of hills, from the top of which they discerned a branch that joins the Coppermine about forty miles from its influx into the sea. Here the Indians killed a few fice buck-deer, procured some excellent firewood, and, as it was not certain that so favourable an opportunity would soon occur again, they sat down with appetites sharpened by long privation, spirits raised by the recollection of hardships overcome, and the almost certain prospect of ere long accomplishing the great object of their expedition, to the most cheerful and comfortable meal they had enjoyed for a long period. The reader will be amused with Hearne's description of this delicious repast, and of the mysteries of Indian cookery. "As such favourable opportunities of indulging the appetite," says he, "happen but seldom, it is a general rule with the Indians, which we did not neglect, to 
exert every art in dressing their food which the most refined skill in Indian cooking has been able to invent, and which consists chiefly in boiling, broiling, and roasting; but of all the diolies cooked by these people, a becatee, as it is called in their language, is certainly the most delicious (at least for a change) which can be prepared from a deer only without any other ingredient. It is a kind of Scotch 'haggis' mate with the blood, a good quantity of fat shred small, some of the tenderest of the flesh, together with the heart and lungs, cut or more commonly torn into small shivers, all which is put into the stomach and roasted, by being suspended over the fire by a string. Care must be taken that it does not get too much heat at first, as the bag would thereby be liable to be burnt and the contents let out. When it is sufficiently done it will emit a rich steam, in the same manner as a fowl or a joint of meat, which is as much as to say, 'Come eat me now !' and if it be taken in time, before the blood or the contents are too much done, it is certuinly a most delicious morsel, even without pepper, salt, or any other seasoning."*

Having regaled themselves in this sumptuous manner, and taken a few hours' rest, they once more set out, and after a walk of nine or ten miles, at last arrived at the Coppermine. Scarcely had Hearne congratulated himself on reaching the great object of his mission, unpacked his surveying instruments, and prepared to follow its progress to the great Arctic Ocean, when one of those dark and terrible scenes occurred which are so strikingly characteristic of savage life. As soon as Matonabbee and his party gained the banks of the river, three spies were sent out to discover whether any Esquimaux were in the neighbourhood. After a short absence they returned with intelligence that they had seen five tents, about twelve miles distant on the west side of the river. All was now warlike preparation; the guns, knives, and spears were carefully examined; and as they learned that the nature of the ground would render it easy to advance unperceived, it was determined to steal upon their victims in this manner, and put them to death. This plan was executed with the most aavage exactness; and nothing could present a more dread.

* Hearne's Journey, p. 144. 
ful view of human nature in its unenlightened state than the perfect unanimity of purpose which pervaded the whole body of Indians upon this horrid occasion, although at other times they were in no respect amenable to discipline.

Each man first painted his target, some with a representation of the sun, others of the noon, and several with the pictures of beasts and birds of prey, or of imaginary beings, which they affirmed to be the inhabitants of the elements upon whose assistance they relied for success in their enterprise. They then moved with the utmost stealth in the direction of the tents, taking care not to cross any of the hills which concealed their approach. It was a miserable circumstance that these poor creatures had taken up their abode in such ground that their enemies, without being observed, formed an ambuscade not 200 yards' distant, and lay for some time watching the motions of the Esquimaux, as if marking their victims. Here the last preparations for the attack were made: the Indians tied up their long black hair in a knot behind, lest it should be blown in their eyes; painted their faces black and red, which gave them a hideous aspect; deliberately tucked up the sleeves of their jackets close under the armpits, and pulled off their stockings; while some, still more eager to render themselves light for running, threw oft their jackets, and stood with their weapons in their hands quite naked, except their breech-clothes and shoes. By the time all were ready it was near one o'clock in the morning; when, finding the Esquimaux quiet, they rushed from their concealment. In an instant, roused by the shouts of the savages, the unfortunate wretches, men, women, and children, ran naked out of the tents, and attempted to escape; but the Indians had surrounded them on the land side, and as none dared to leap into the river, all were murdered in cold blood; while Hearne, whom a regard for his personal safety had compelled to accompany the party, stood a short way off rooted to the ground in horror and agony.

"The shrieks and groans of the poor expiring wretches," says he, in his striking account of this dreadful episode in savage life, "were truly distressing; and my horror was much increased at seeing a young girl, about eighteen years of age, lilled so near me that when the first spear was struck into her side she fell down at my feet and twisted 
round my legs, so that it was with difficulty that I could disengage myself from her dying grasps. As two Indian men pursued this unfortunate victim, I solicited very hard for her life; but the murderers made no reply till they had stuck both their spears through her body and transfixed her to the ground. They then looked me sternly in the face, and began to ridicule me by asking if I wanted an Esquimaux wife, while they paid not the smallest regard to the shrieks and agony of the poor wretch, who was turning round their spears like an eel. Indeed, after receiving from them much abusive language on the occasion, I was at length obliged to desire that they would be more expeditious in despatching their victim out of her misery, otherwise I should be obliged out of pity to assist in the friendly office of putting an end to the existence of a fellow-creature who was so cruelly wounded. On this request being made, one of the Indians hastily drew his spear from the place where it was first lodged, and pierced it through her breast near the heart. The love of life, however, even in this most miserable state, was so predominant, that though this might be justly cailed the most merciful act which could be done for the poor creature, it seemed to be unwelcome; for, though much exhausted by pain and loss of blood, she made several efforts to ward off the friendly blow. My situation and the terror of my mind at beholding this butchery cannot easily be conceived, much less described: though I summoned up all the fortitude I was master of on the occasion, it was with difficulty that I could refrain from tears ; and I am confident that iny features must have feelingly expressed how sincerely I was affected at the barbarous scene I then witnessed. Even at this hour I cannot reflect on the transactions of that horrid day without shedding tears." *

After making an accurate survey of the river till its junction with the sea, Hearne proceeded to one of the copper-mines, which he found scarcely to deserve the name, it being nothing more than a chaotic mass of rocks and gravel, rent by an earthquale, or some other convulsion, into numerous fissures, througl one of which flowed a small river. Although the Indians had talked in magnificent 
terms of this mine, after a search of four hours a solitary piece of ore was all that could be discovered; and instead of pointing out the hills entirely composed of copper, and the quantities of rich ore with which they had affirmed it would be easy to freight a large vessel, they now told a ridiculous story of some insults offered to the goddess of the mine, who in revenge declared that she would sit upon it till she and it sunk together into the earth. In consequence of this threat, they next year found her sunk up to the waist, and the quantity of copper much decreased, while the following summer she had entirely disappeared, and the whole mine along with her.

In reaching the sea, Hearne had accomplished the great object of his journey, and his homeward route did not vary materially from his course to the Arctic Ocean. On 31st July, they arrived at the place where the Indians had left their families, and on 9th August resumed their course to the south-west; travelling with frequent intervals of rest till, on 24th November, they reached the northern shore of the great Athabasca Lake. In this latitude, at this season, the sun's course formed an extremely small segment of a circle above the horizon, scarcely rising half-rvay up the trees; but the brilliancy of the stars, and the vivid and beautiful light emitted by the aurora borealis, even without the aid of the moon, amply compensated for the want of the sun, so that at midnight Hearne could see to read very small print. In the deep stillness of the night, also, these northern meteors were distinctly heard to make a rushing and crackling noise, like the waving of a large flag in a fresh gale of wind." Accorling to the information of the natives, the Athabasca Lake is nearly 120 leagues long from east to west, and tiventy wide from north to south. It was beautifully studded with islands, covered with tall poplars, birch, and pines, which were plentifully stocked with deer, and abounded with pike, trout, and barbel, besides the species known by the Indians under the names of tittameg, methy, and shees.

The country through which they had hitherto travelled had been extremely barren and hilly, covered with stunted firs and dwarf willows; but it now sulsided into a finc 
plain, occasionally varied with tall woods, and well stocked with buffalo and moose-deer. The party spent some days wi..' much pleasure in hunting; and as the flesh of the younger buftaloes was delicious, their exhausted stock of provisions was seasonably supplied. In one of their excursions an incident occurred strikingly characteristic of savage life The Indians came suddenly on the track of a strange snow-shoe, and following it to a wild part of the country, remote from any human habitation, they discovered a hut, in which a young Indian woman was sitting alone. She had lived for the last eight moons in absolute solitude, and recounted with affecting simplicity the circumstances by which she had been driven from her own people. She belonged, she said, to the tribe of the Dog-ribbed Indians, and in an inroad of the Athabasca nation, in the summer of 1770 , had been taken prisoner. The savages, according to their invariable practice, stole upon the tents in the night, and murdered before her face her father, mother, and husband, while she and three other young women were reserved from the slaughter, and made captive. Her child, four or five months old, she contrived to carry with her, concealed among some clothing; but on arriving at the place where the party had left their wives, her precious bundle was examined hy the Athabasca women, one of whom tore the infant from its mother, and killed it on the spot. In Europe, an act so inhuman would, in all probability, have been instantly followed by the insanity of the parent; but in North America, though maternal affection is equally intense, the nerves are more sternly strung. So horrid a cruelty, however, determined her, though the man whose property she had become was kind and careful of her, to take the first opportunity of escaping, with the intention of returning to her own nation; but the great distance, and the numerous winding rivers and creeks she had to pass, caused her to lose the way, and winter coming on, she had built a hut in this secluded spot. When discovered, she was in good health, well fed, and in the opinion of Hearne one of the finest Indian women he had ever seen. Five or six inches of hoop made into a knife, and the iron shank of an arrow-head which served as an awl, were the only implements she possessed; and with these she made snow-shoes and other useful articles. For subsistence she 
snared partridges, rabbits, and squirrels, and had killed two or three beavers and some porcupines. After the few deersinews she had brought with her were expended in making snares and sewing her clothing, she supplied their place with the sinews of rabbits' legs, which she twisted together with great dexterity. Thus occupied, she not only became reconciled to her desolate situation, but had found time to amuse herself by manufacturing little pieces of personal ornament. Her clothing was formed of rabbit-skins sewed together; the materials, though rude, being tastefully disposed, so as to make her garb assume a pleasing though desert-bred appearance. The singular circumstances under which she was found, her beauty and useful accomplishments, occasioned a contest among the Indians, as to who should have her for a wife; and the matter being decided, she accompanied them in their journey. On 1st March, they left the level country of the Athabascas, and approached the stony hills bounding the territories of the Northern Indians, traversing which they arrived in safety at Prince of Wales' Fort on the 29 ih of June, 1772, having been absent eighteen months and twenty-three days.

The journey of Hearne must be regarded as forming an important era in the geography of America. For some time it had been supposed that this vast contment extended in an almost unbroken mass towards the Pole; and we find it thus depicted in the maps of that period. The circumstance of Hearne having reached the shore of the great Arctic Ocean at once demonstrated the fallacy of all such ideas. It threw a new and clear light upon the structure of this portion of the globe, and resting upon the results thus distinctly ascertained, the human mind, indefatigable in the pursuit of knowledge, started forward in a career of still more enlarged and interesting discovery.*

While the Hudson's Bay Company, by the mission of Mr. Hearne, vindicated their character from the charge of indifference to the cause of geographical discovery, another institution had arisen, under the title of the North-west Fur Company, which, though it did not rest on a royal charter, and had experienced in its earliest exertions many severe reverses, at last arrived, by the intelligence and perseverance

- Murray's Discoveries and Travels in North America, vol. ii. p. 149 
of its partners and servants, at a degree of prosperity which surpassed the chartered companies of France and England. In the counting-house of Mr. Gregory, a partner of this company, was bred a native of Inverness, named Alexander Mackenzie. In conducting the practical details of the furtrade, he had been settled at an early period of life in the country to the north-west. of Lake Superior, and became animated with the ambition of penetrating across the continent: for this undertaking he was eminently qualified, possessing an inquisitive and enterprising mind, with a strong frame of body, and combining the fervid and excursive genius which has been said to characterize the Scots in gencral, with that more cautious and enduring temperament which belongs to the northern Highlander.

On 3d June, 1789, Mackenzie set out from Fort Chepewyan, at the head of the Athabasca Lake, a station nearly central between Hudson's Bay and the Pacific. He had resided here for eight years, and was familiar with the difficulties of the journey as well as aware of the most likely methods of surmounting them. He took with him four canoes. In the first he embarked with a German and four Canadians, two of the latter being accompanied by their wives. A Northern Indian, called the English Chief, who had been a follower of Matonabbee, the guide of Mr. Hearne, occupied the second with his two wives. The third was paddled by two stout young Indians, who acted in the double capacity of hunters and interpreters ; while the fourth was laden with provisions, clothing, ammunition, and various articles intended as presents for the Indians. 'This last canoe was committed to the charge of Mr. Le Roux, one of the company's clerks.

On 4th June, the party reached the Slave River, which connects the Athabasca and Slave Lakes, in a course of about one hundred and seventy miles; and on the 9th of the same month they arrived at the Slave Lake, without experiencing any other inconveniences than those arising from th? attacks of the mosquitoes during the heat of the day, and the extreme cold in the morning and evening. In the river were frequent rapids, which obliged them to land and transport their canoes and luggage over the carrying-places, - a toilsome process, but attended with no danger, as the path had been cleared by the Indians trading with the com- 
pany. The banks were covered with various linds of trees ; but, owing to its inferior level and its rich black soil, the western side was more thickly wooded than the other. On the eastern bank, composed of a yellow clay mixed with gravel, the trees were smaller, but in full leaf, though the ground was not thawed above fourteen inches in depth. At it little distance from the river were extensive plains frequented by herds of buffaloes; the woods bordering its sides were tenanted by moose and rein-deer; and numerous colonies of beavers built their habitations on the small streams which fed the lake. This large body of water was covered with ice, which had not given way except in a small strip round the shore, where the depth, nowhere exceeding three feet, was scarcely sufficient to float the canoes. Though now the 9 th of June, there was every appearance that the ice would detain the expedition for a considerable time; and it was thought necessary to pitch their tents. The nets were now set; the Indians went off in different directions to hunt; the women gathered berries of various sorts, which abounded in the neighbouring woods; and their larder was soon supplied with plenty of geese, ducks, and beaver, excellent trout, carp, and white-fish, and some dozens of swan and duck eggs, which were picked up on an adjacent island. Their stay, therefore, was far from unpleasant, combining the novelty of a residence in a strange country with the ex citation and variety of a hunter's life; and on the 15th, after a rest of six days, as the ice had given way a little, they resumed their journey.

Since leaving Athabasca, the twilight had been so bright, owing to the short disappearance of the sun below the horizon, that even at midnight not a star was to be seen; but as they glided along the lake they were greeted by the moon, which rose beatififully above the woods, with her lower horn in a state of eclipse. The obscuration continued for about six minutes in a cloudless sky.* Coasting along the shore, they came to a lodge of Red Knife Indians, so denominated from their using copper knives. One of these men engaged to conduct them to the mouth of the river which was the object of their search; but such were the impediments encountered from drift-ice, contrary winds, and 
the ignorance of the guide, whom the English Chief threatened to murder for engaging in a service for which he was unfit, that it was the 29 th of the month before they embarked upon the river since known by the name of the traveller who now first ascended it. On leaving the lake, the Mackenzie River was found to run to the westward, becoming gradually narrower for twenty-four miles, till it diminished into a stream not more than half a mile wide, with a strong current, and a depth of three and a half fathoms. A stiff breeze from the eastward now drove them on at a great rate, and after a rapid run of ten miles, the channel gradually widened till it assumed the appearance of a small lake, which proved to be the utmost limit known to their guide. They now came in sight of the chain of the Horn Mountains, bearing north-west, and had some difficulty in recovering the channel of the river.

Having resumed their course on 1st July, they met with no interruption for five days, when they observed several smokes on the northern bank. On landing they discovered an encampment of five farilies of Slave and Dog-ribhed Indians, who on the first appearance of the party fled into the woods in consternation. The entreaties of the English Chief, whose language they understood, at length dissipated their apprehensions ; and the distribution of a few beads, rings, and knives, with a supply of grog, reconciled them entirely to the strangers. Their account of the difficulties in the farther navigation of the river was not a little appalling : they asserted that it would require several winters to reach the sea, and that old age would inevitably overtake the party before their return. Monsters of horrid shapes and malignant disposition were represented as having their abodes in the rocky caves on the banks, ready to devour the presumptizous traveller who approached; and the more substantial impediment of two impassable falls was said to exist about thirty days' march from where they then were.

Though such tales were treated with contempt by Mackenzie, the Indians, already tired of the voyage, drank them in with willing ears, and they could scarcely be persuaded to pursue their journey. On consenting to proceed, one of the Dog-ribbed Indians was induced, by the present of a kettle, an axe, and some other articles, to accompany them as a guide; but when the time of embarkation arrived, his 
love of home came upon him with such violence that he used every artifice to escape from his agreement, and at last was actually forced on board. Previous to his departure, a singular ceremony took place: with great solemnity he cut off a lock of his hair, and dividing it into three parts, fastened one to the upper part of his wife's head, blowing on it thrice with the utmost violence, and uttering certain words as a charm. The other two locks he fixed with the same ceremonies to the heads of his two children. These Indians were in general a meager, ugly, and ill-favoured race, particularly ill-made in the legs. Some of them wore their hair very long, others allowed a tress to fall behind, cutting the rest short round their ears. A few old men had beards, while the young and midule-aged appeared to have pulled out every hair on their chin. Each cheek was adorned by two doub'e lines tattooed from the ear to the nose, of which the gristle was perforated so as to admit a goose-quill or a small piece of wood. Their clothing consisted of dressed deer-skins. For winter wear these were prepared with the fur, and the shirts made of them decorated with a neat embroidery, composed of porcupine-quills and the hair of the moose-deer, coloured red, black, yellow, or white. Their shirts reached to the mid-thinh, while their upper garments covered the whole body, having a fringe round the bottom. Their leggins, which were embroidered round the ankle and sewed to their shoes, reached to mid-thigh. The dress of the women was nearly the same as that of the men. They wore gorgets of horn or wood, and had bracelets of the same materials. On their head was placed a fillet or bandeau, formed of strips of leather, embroidered richly with porcupine-quills, and stuck round with bears' claws or talons of wild fowl. Their belts and garters were neatly constructed of the sinews of wild animals and porcupine-quills. From these belts descended a long fringe composed of strings of leather, and worked round with hair of various colours, and their mittens hung from their neck in a position convenient for the reception of their hands. ${ }^{*}$ Their arms and weapons for the chase were bows and arrows, spears, daggers, and a large club formed of the rein-deer horn, called a pogamagan. The bows were about five or six feet

- Mackenzie's Travels, p. 35-3i. 
long, with strings of sinews; and flint, iron, or copper, supplied barbs to the arrows. Their spears, nearly six feet long, were pointed with bone, while their stone axes were fastened with cords of green skin to a wooden handle. Their canoes were light, and so small as to carry only one person.

On 5th July, the party re-embarked. Continuing their course west-south-west they passed the Great Bear Lake River; and steering through numerous islands, came in sight of a ridge of snowy mountains, frequented, according to their guide, by herds of bears and small white buffaloes. The banks of the river appeared to be pretty thickly peopled; and though at first the natives uniformly attempted to escape, the offer of presents generally brought them back, and procured a seasonable supply of hares, partridges, fish, or reindeer. The same stories of spirits or manitous which haunted the stream, and of fearful rapids that would dash the canoes to pieces, were repeated by these tribes; and the guide, upon whom such representations had a powerful effect, decamped in the night during a storm of thunder and lightning. His place, however, was soon supplied; and, after a short sail, they approached an encampment of Indians, whose brawny figures, healthy appearance, and great cleanliness showed them to be a superior race to those lately passed. From them Mackenzie learned that he must sleep ten nights before arriving at the sea, and in three nights would meet the Esquimaux, with whom they had been formerly at war, but were now in a state of peace. One of these people, whose language was most intelligible to the interpreter, agreed to accompany the party; but became dreadfully alarmed when some of the men discharged their fowling-pieces. It was evident none of this race had ever heard the report of firearms. To reconcile him to his departure, his two brothers followed in their cances, and diverted him with native songs, and other airs said to be imitations of those of the Esquimaux. The triumph of music was never more strikingly exhibited; from deep dejection the Indian at once passed into a state of the highest and most ludicrous excitement, keeping time to the songs by a variety of gratesque gesticulations, performed with such unceasing rapidity and so little regard to the slenderness of the bark, which quivered under his weight, that they expected 
every moment to see it upset. In one of his paroxysms, shooting his canoe alongside of Mackenzie's, he leaped into it, and commenced an Esquimaux dance. At last he was restored to some degree of composure, which became complete on their passing a hill, where he informed them that three winters ago the Esquimaux had slain his grandfather.*

Mackenzie soon after reached the tents of a tribe named Deguthee-Dinees, or Quarrellers, who justified their name by the menacing gestures with which they received the strangers' approach. A few presents, however, reconciled them to the intrusion; and they communicated the gratifying intelligence that the distance overland to the sea, either by an easterly or westerly route, was inconsiderable. The party now pushed on with renewed hopes; and the river soun after separating into several streams, they chose the middle and largest, which ran north. This shortly brought in sight a range of snowy mountains, stretching far to the northward; and, by an observation, Mackenzie found the latitude to be $67^{\circ} 47^{\prime}$, which convinced him that the waters on which their frail barks were then gliding must flow into the great Hyperborean Ocean.t At this moment, when within a few days of accomplishing the great object of their journey, the Indians sank into a fit of despondency and hesitated to proceed. The guide pleaded his ignorance of the country, as he had never before penetrated to the shores of the Benahulla Toe, or White Man's Lake. Mackenzie assured them he would return if they did not reach it in seven days, and prevailed on them to continue their course.

It was now the 11 th of July, and the sun at midnight was still considerably above the horizon, while every thing denoted the proximity of the sea. On landing at a deserted encampment, still marked by the ashes of some Esquimaux fires, they observed several pieces of whalebone, and a place where train-oil had been spilt. Soon after they came to three houses recently left by the natives. The ground-plot of these habitations was oval, abont fifteen feet long, ten feet wide in the middle, and eight feet at either end; the whole was dug about twelve inches below the 
surface, one half being covered with willow-branches, and probably forming the bed of the whole family. In the middle of the other half, a space four feet wide, which had been hollowed to the depth of twelve inches, was the only spot where a grown person could stand upright. One side of it was eovered with willow-branches, and the other formed the hearth. The door, in one end of the house, was about two feet and a lualf high by two feet wide, and was reached through a covered way about five feet long; so that the only access to this curious dwelling was by creeping on all-fours. On the top was an orifice about eighteen inches square, which served the triple purpose of a window, a chimney, and an occasional door. The underground part of the floor was lined with split wood, while cross pieces of timber, laid on six or eight upright stakes, supported an oblung square roof; the whole being formed of drift-wood, and covered with branches and dry grass, over which was spread earth a foot thick. On either side of these houses were a few square holes, about two feet deep, covered with split wood and earth, excepting one small place in the middle, which appeared to be contrived for the preservation of the winter stock of provisions. In and about the houses lay sled-runners, and bones, pieces of whalebone, and poplar-bark cut in circles, used evidently to buoy the nets; and before each habitation a great number of stumps of trees were driven into the ground, upon which its late possessors had probably hung their nets and fish to dry in the sun.

The signs of vegetation were by this time scarcely perceptible; the trees had dwindled into a few dwarf willows, not more than three feet high; and though the footmarks on the sandy beach of some of the islands showed that the natives had recently been there, all attempts to obtain a sight of them proved unavailing. The discontent of the guide and of the Indian hunters was now renewed; but their assertion, that on the morrow they were to reach a large lake in which the Esquimaux killed a huge fish, and whose shores were inhabited by white bears, convinced Mackenzie that this description referred to the Arctic Sea, with its mighty denizen the whale. He accordingly pressed forward with fresh ardour, and the canoes were soon carried by the current to the entrance of the lake, which, 
from all the accompanying circumstances appears to have been an arm of the Arctic Ocean. It was quite open to the westward, and by an observation the latitude was found to be $69^{\circ}$. From the spot where this survey was taken they now continued their course to the westernmost point of a high island, which they reached atter a run of fifteen miles, and around it the utmost depth of water was only five feet. The lake appeared to be covered with ice for about two leagues' distance, no land was seen ahead, and it was found impossible to proceed farther. Happily, when they had thus reached the farthest point of their progress northward, and were about to return in great disappointment, two circumstances occurred which rendered it certain that they had penetrated to the sea: the first was the appearance of many large floating substances in the water, believed at first to be masses of ice, which, on being approached, turned out to be whales; and the second, the rise and fall of the tide, observed both at the eastern and western end of the island, which they named Whale Island.* Having in company with the English Chief ascended to its highest ground, Mackenzie saw the solid ice extending to the eastivard; and to the west, as far as the eye could reach, they dimly discerned a chain of mountains, apparently about twenty leagues' distance, stretching to the northward. Many islands were seen to the eastward; but though they came to a grave, on which lay a how, a paddle, and a spear, they met no living human beings in these arctic solitudes. The red-fox and the reindeer, flocks of beautiful plovers, some venerable white owls, and several large white gulls were the only natives. Previous to setting out on their return, a post was erected close to the tents, upon which the traveller engraved the latitude of the place, his own name, the number of persons by whom he was accompanied, and the time they had spent on the island.

It was now the 16 th of July, and they re-embarked on their homeward voyage. On the 21 st the sun, which for some time had never set, descended below the horizon, and the same day eleven of the natives joined them. They represented their tribe as numerous, and perpetually at

* Dackenzie, p. 64, 65 . 
war with the Esquimaux, who had broken a treaty into which they had inveigled the Indians, and butchered many of them. Occasionally a strong body ascended the river in large canoes, in search of flints to point their spears and arrows. At present they were on the banks of a lake to the eastward, hunting rein-deer, and would soon begin to catch big fish (whales) for their winter stock. They had been informed that the same Esquimaux, eight or ten winters ago, saw to the westward, on White Man's Lake, several large canoes full of white men, who gave iron in exchange for leather. On landing at a lodge of natives farther down the river, the English Chief obtained some other particulars from a Dog-ribbid Indian, who had been driven by some private quarrel frum his own nation, and lived among the Hare Indians. According to his information, there was a much larger river to the south-west of the mountains, which fell into White Man's Lake. The people on its banks were a gigantic and wicked race, who could kill common men with their eyes, and sailed in huge canoes. There was, he added, no known communication by water with this great river; but those who had seen it went over the mountains, and it flowed towards the mid-day sun. This description proceeded, he acknowledged, not from personal observation, but was taken from the report of others who inhavited the opposite mountains. Mackenzie, having fallen in with one of these strangers, by a bribe of some beads prevailed upon him to delineate the circumjacent country and the course of the unknown river upon the sand. The map proved a very rude production. He traced out a long point of land between the rivers without paying the least attention to their courses. This isthmus he represented as running into the great lake, at the extremity of which, as he had been told by Indians of other nations, there was built a Berabulla Couin, or White Man's Fort. "This," says Mackenzie, "I took to be Oonalaska Fort, and consequently the river to the west to be Cook's River, and that the body of water or sea into which the river discharges itself at Whale Island communicated with Norton Sound."

Mackenzie now endeavoured to procure a guide across the mountains, but the natives steadily refused; and any ad- 
ditional intelligence which they communicated regarding the country only consisted of legends concerning the supernatural power and ferocity of its inhabitants. They were represented as a sort of monsters with wings, who fed on huge birds, which, though killed by them with ease, no other mortal would venture to assail. Having gravely stated this, they began both young and old to jump and dance with astonishing violence and perseverance, imitating the cries of the rein-deer, bear, and wolf, in the hope of intimidating Mackenzie; but when he threatened with an angry aspect to force one of them along with him across the mountains, a sudden fit of sickness seized the whole party, and in a faint tone, which formed a ludicrous contrast to their former vociferation, they declared they would expire the instant they were taken from their homes. In the end the traveller was compelled to leave them without accomplishing his object.*

On 1st August, as the expedition approached the river of the Bear Lake, the stars, which hitherto, from the extreme clearness of the twilight, had continued invisible, began to twinkle in the sky; and the air, from being oppressively sultry, became so cold that perpetual exercise could scarcely keep the men warm. The women were now constantly employed in making shoes of moose-skin, as a pair did not last more than a day, while the hunters brought in supplies of geese, rein-deer, and beaver; and on one occasion a wolf was killed, roasted, and eaten with great satisfaction. On 22d August, they reached the entrance of the Slave Lake, after which their progress homeward presented no feature of interest, and on 12th September they arrived in safety at Fort Chepewyan, after an absence of 102 days. The importance of this journey must be apparent, on considering it in connexion with the expedition of Hearne. Both travellers had succeeded in reaching the shores of an arctic sea; and it became not only an established fact that there was an ocean of great extent in the north of America, but it was rendered extremely probable that this sea formed its continuous boundary.

Mackenzie concluded his first journey in September, 1789,

* Mackenzie, p. 87. 
and about three years afterward undertook a second expedition, which proved still more difficult and hazardous, and equally important and satisfactory in its results. His object was to ascend the Peace River, which rises in the Rocky Mountains, and crossing these, to penetrate to that unknown river which in his former journey had been the subject of his unwearied inquiry. 'T'his he conjectured must communicate with the sea; and, pursuing its course, he hoped to rench the shores of the Pacific. Setting out accordingly on 10th October, 1792, he pushed on to the remotest European settlement, where he spent the winter in a traffic for furs with the Beaver and Rocky Indians. Having despatched six canoes to Fort Chepewyan with the cargo he had collected, he engaged hunters and interpreters, and launched the canoe in which he had determined to prosecute his discoveries. Her dimensions were twenty-five feet long within, exclusive of the curves of stem and stern, twenty-six inches hold, and four feet nine inches beam. She was at the same time so light, that two men could carry her three or four miles without resting. In this slender vessel they not only stowed away their provisions, presents, arms, armunition, and baggage, to the weight of 3000 pounds, but found room for seven Europeans, two Indians, and the leader himself. On embarking, the winter interpreter left in charge of the fort could not refrain from tears when he anticipated the dangers they were about to encounter, while they themselves fervently offered up their prayers to Almighty God for a safe return.

The commencement of their voyage was propitious; and under a serene sky, with a keen but healthy air, the bark glided through some beantiful scenery. On the west side of the river the ground rose in a gently-ascending lawn, broken at intervals by abrupt precipices, and extending in a rich woodland perspective as far as the eye could reach. This magnificent amphitheatre presented groves of poplar in every direction, whose openings were enlivened with herds of elks and bufialoes; the former choosing the steeps and uplands, the latter preferring the plains. At this time the buffaloes were attended by their young ones, which frisked about, while the female elks were great with young. The whole country displayed an exuberant verdure: the trees which bore blossoms were rapidly bursting into 
flower, and the soft velvet rind of the branches reflected the oblique rays of a rising or a setting sun, imparting a cheerfulness and brilliancy to the scene, which gladdened the heart with the buoyant influences of the season.* After a few days the air became colder, the country more desolate, the track of the large grisly bear was discerned on the banks, and the weather was occasionally broken by storms of thunder and lightning.

From this time till the 21st of May, the passage was attended with difficulties that would have disheartened a less energetic leader. The river beimg broken by frequent cascades and dangerous rapids, it was necessary to carry the canoe and luggage till they could resume their voyage in safety. On their nearer appronch to the Rocky Mountains, the stream, hemmed in between stupendous rocks, presented a continuance of frightful torrents and impracticable cataracts. The dangers to which they had already been exposed had greatly disheartened the men, and they began to murmur audilily, so that no alternative was left but to return. Indeed there was some reason for this irresolution; by water farther progress was impossible, and they could only advance over a mountain whose sides were broken by sharp jagged rocks, and thickly covered with wood. Mackenzie despatched a reconnoitring party, with orders to ascend the mountain, and proceed in a straight course from its summit, keeping the line of the river till they ascertained that it was navigable. During their absence his people repaired the canoe, while he took an altitude, which ascertained the latitude to be $56^{\circ} 8^{\prime}$. At sunset the scouts returned by different routes. They had penetrated through thick woods, ascended hills, and dived into valleys, till they got beyond the rapids, and agreed, that though the difficulties to be encountered by land were alarming, it was their only course. Unpromising as the task appeared, their spirits had risen and their murmurs were forgotten; so that a kettle of wild rice sweetened with sugar, with the usual evening regale of rum, renewed their courage; sind, after a night's rest, they proceedied at break of day on their laborious journey.

In the first place, the men cut a road up the mountain

- Mackenzie's Travels, p. 154, 155. 
where the trees were smallest, felling some in such a mannor as to malie them fall parallel to the road without separating them entirely from the stumps, in this way forming a kind of railing on either side. The baggage and the canoe were then brought from the water-side to the encampment,- -an undertaking exceedingiy perilous, as a single false step must have been followed by immersion into the river, which flowed here with furious rapidity. Having accomplished this labour, the party breathed a little, and then ascended the mountain with the canoe, having the line or rope by which it was drawn up doubled, and fastened successively to the stumps left for this purpose, while a man at the end hauled it round a tree, holding it on and shifting it as they advanced. In this manner the canoe was warped up the steep; and by two in the afternoon every thing had been carried to the summit. Men were then despatched to cut the road onwards : and the incessant labour of another day could only penetrate about three miles, while mountains much more elevated raised their snowy summits around in every direction. These, however, were at a distance ; and another day's exertion brought them through a wood of tall pines to the banks of the river above the rapids. Before again embarking, Mackenzie left attached to a pole a knife, a steel, flint, beads, and other trifles, as a token of amity to the natives; and one of his Indians added a small round stick of green wood, chewed at one end in the form of a brush, used to pick marrow out of bones, - an instrument which he explained to be intended as an emblem to the people of a country aboundirg in animals.*

They now resumed their voyage, enclosed on all sides by mountains whose summits were covered with snow, and one of which to the south rose to a majestic height. The air became chill; the water, through which they frequently waded, towing or pushing their bark, was intensely cold; and on 3 lst May, they reached a point minutely described to them before setting out by an old Indian warrior. Here the river separated into two streams, one running westnorth-ivest, and the other south-south-east. The first of these they had been warned to avoid, as it soon lost itself in various smaller currents among the mountains; and the

t Mackenzie, p. 181. 
steersman accordingly proceeded into the eastern branch, which, though not so broad as the other, was far more rapid. The course of their journey now led them through many populous beaver-settlements. In some places these animals had cut down several acres of large poplars; and they saw multitudes busy from sunrise to sunset erecting houses, procuring food, superintending their dikes, and going diligently through all the labours of their little commonwealth. Perceiving soon after a smoke in the forest which lined the banks, and hearing the sounds of human voices in great confusion, they became aware that they were near an Indian encampment from which the inhabitants were retreating. Accordingly, on approaching the shore, two ferocious-looking men sprang from the woods and took their station on a rising ground, brandishing their spears with loud vociferations. A few words of explanation from the interpreter, and some presents, pacified them, and Mackenzie made anxious inquiries regarding the nature of the country, and the great river which formed the object of his search. To his mortification he found that they were unacquainted with any river to the westward; they had just arrived over a carrying-place of eleven days from another stream, which was nothing else than a large branch of the one the expedition was then navigating. Their iron, they said, was procured in exchange for beaver and dress mooseskins from the people there, who travelled during a moon to the country of other tribes living in houses, and these in their turn extended their journeys to the ocean; or, to use their disparnging epithet, the Great Stinking Lake, where they traded with white people, who came in canoes as large as islands. Their knowledge of the country, however, appeared so vague, that all hope of procuring a guide was vain, and the heart of the traveller sank within him as he felt that his favourite project was on the point of being utterly disconcerted.

Amid this despondency a faint hope remained that the natives, under the influence of suspicion, timidity, or from imperfectly understanding the interpreter, had not communicated all they knew; and after a night sleepless from anxiety, the traveller rose with the sun to repeat his in. quiries. At first nothing satisfactory could be elicited; but suddenly, Mackenzie, who stood beside the interpreters, 
understood, from the few words he knew of their language, that one person mentioned a great river, while he pointed significantly to that which lay before them. On a strict inquiry, the interpreter, who had been tired of the voyage, and of whose fidelity some suspicion was entertained, acknowledged that the Indian spoke of a large river whose course was towards the mid-day sun, a branch of which flowed near the source of the stream they were now navigating. This branch, he added, it would not be difficult to reach, there being only three small lakes and as many carrying-places on the way to it; but he also insisted that the great river did not discharge itself into the sea.* This last assertion was imputed to his ignorance of the country, while a rude map, which he delineated with a piece of coal on a strip of bark, convinced them that his information, so far as it went, was to be relied on. A new ray of hope now arose; and having induced an Indian to go forward as a guide to the borders of the small lakes, Mackenzie resumed his journey on 10th June, promising, if successful in his object, to revisit these friendly Indians in two moons.

These people were of low stature and meager frame, owing probably to the difficulty of procuring subsistence; round faces, high cheek-bones, black hair hanging in elflocks over their shoulders, and a swarthy yellow complexion, combined to give them a forbidding aspect; while their garments of beaver, rein-deer, and ground-hog skins, dressed with the hair outside, having the tail of this last animal hanging down the back, might, when seen at a distance, occasion some doubt whetier they belonged to the human race. Their women were extremely ugly, lustier and taller than the men, but much inferior in cleanliness. Their warlike weapons were cedar bows, six feet long, with a short iron spike at one end, so that they might also be used as spears. The arrows were barbed with iron, flint, stone, or bone, from two to two feet and a half long, and feathered with great neatness. They had two kinds of spears, both douhle-edged, of well-polished iron, and with shafts from six to eight feet long. Their knives were of iron worked by themselves, and their axes resembled a carpenter's adze. They used snares of green skin, nets and

* Mackenzie, p. 203, 204, 
fishing-lines of willow-bark, hooks of small bones, and liettles of watape so closely woven as not to leak. Besides these they had various dishes of wood and bark, horn and wooden spoons and buckets, and leathern and net-work bags. Their canoes, of spruce-bark, calculated to hold from two to five persons, were nropelled by paddles six feet long, with the blade shaped like a heart.*

Pursuing their journey under the direction of the new guide, they reached a small lake in latitude $54^{\circ} 24^{\prime}$, which Mackenzie considered as the highest or southernmost source of the Ungigah or Peace River. They passed two other lakes, and again entered the river, the navigation of which, from its rapidity and the trees and rocks in its channel, now became dangerous. The canoe struck on a sharp rock, which shattered the stern, and drove her to the other side, where the bow met the same fate; to complete the disaster, she passed at this moment over a cascade, which broke several holes in her bottom, and reduced her to a complete wreck, lying flat upon the water. All hands now jumped out, and clinging desperately to the sides, were hurried several hundred yards through a foaming torrent beset with sharp rocks, upon which they were every instant in danger of being dashed to pieces. Being carried, however, into shallow water, where the canoe rested on the stones, they were relieved from their perilous situation by their companions on shore.

After this escape, a consultation was held regarding their future proceedings. Benumbed with cold, and intimidated by their recent dangers, the Indians proposed an immediate return; but the remonstrances of their leader, enforced by the usual arguments of a hearty meal and an allowance of rum, hanished their fears. It was next proposed to abandon the wreck, to carry the baggage to the river, which the guide affirmed to be at no great distance, and there to construct a new ressel. But as it was suspected that this representation was not to be relied on, a party was despatched to reconnoitre, and brought back a very confused and unpromising account of the country. It was therefore determined to repair the canoe, and proceed as before. For this purpose bark was collected, which, with a few pieces

- Mackenzie's Travels, p. 205, 206. 
of oil-cloth and plenty of gum, restored their shattered boat to something like a sea-worthy condition. Her frail state, however, rendered it necessary to carry part of the lading on men's shoulders along the banks; and as a road had to be opened with hatchets, their progress was extremely slow.

On 16th .June, Mr. Mackay and two Indians were despatched with orders to penetrate if possible to the great river in the direction indicated by the guide. They succeeded; but returned with a discouraging account of the interminable woods and deep morasses which intervened. These gloomy prospects were increased by the desertion of their guide; but nothing could repress Mackenzie's ardour. Cutting a passage through the woods, carrying the canoe round the rapids and cascades, they held on their slow and toilsome wry, till at last, after passing a swamp, in many places wading to mid-thigh, they enjoyed the satisfaction of reaching the bank of the great river, which had been the object of so much anxious expectation and protracted hope.*

Embarking anew, they were borne along by a strong current, which, slackening after a short time, allowed them to glide gently between banks of high white cliffs, surmounted with grotesque and singularly-shaped pinnacles. After some progress, the party were alarmed by a lond whoop from the thick woods; at the same moment a canoe guided by a single savage shot out from the mouth of a small tributary stream, and a number of natives, armed with bows and arrows, appeared on an adjacent rising ground, uttering loud cries, and manifesting by their gestures that instant death would be inflicted on any one who landed. Every attempt to conciliate them proved unavailing; and a canoe was observed to steal siviftly down the river, with the evident design of communicating the alarm and procuring assistance. At this critical moment the courage and prudence of Mackenzie providentially saved his party. $\mathrm{He}$ landed alone, with two pistols stuck in his belt; having first, however, given orders to one of his Indians to steal into the woods with a couple of guns, and to keep near him in case of attack. "I had not been long," says he, "in my station on the bank, with my Indian in ambush behind me,

* Mackenzie's Travels, p. 228. 
when two of the natives came off in a canoe, but stopped when they got within one hundred yards of me. I made signs for them to land, and as an inducement displayed looking-glasses, beads, and other alluring trinkots. At length, but with every mark of extreme apprehensicn, they approached the shore, taking care to turn their cance stern foremost, and still not venturing to land. I now made them a present of some beads, with which they were going to push off, when I renewed my entreaties, and after some time prevailed on them to come ashore and sit down by me. My Indian hunter now thought it right to join me, arsd created some alarm in my new acquaintance. It was, however, soon removed, and I had the satisfaction to find that he and these people perfectly understood each other. I instructed him to say every thing to them which might tend to sooth their fears and win their confidence. I expressed my wish to conduct them to our canoe; but they declined this offer and when they observed some of my people coming towarc's us, they requested me to let them return, and I was so well satisfied with the progress which I had made in my intercourse with them, that I did not hesitate a moment in complying with their desire. During their short stay they observed us, and every thing about us, with a mixture of admiration and astonishment. We could plainly perceive that their friends received them with great joy on their yeturn, and that the articles which they carried back with them were examined with a general and eager currosity : they also appeared to hold a consultation which lasted about a quarter of an hour, and the result was an invitation to come over to them, which we cheerfully accepted. Nevertheless, on our landing, they betrayed evident signs of confusion, which arose probably from the quickness of our movements, as the prospect of a friendly communication had so cheered the spirits of the people that they paddled across the river with the utmost expedition. The two men who had been with us appeared very naturally to possess the greatest share of courage on the occasion, and were ready to receive us on our landing; but our demeanour soon dispelled their apprehensions, and the most familiar communication took place between us. When I had secured their confidence by the distribution of trinkets among them, and had traatel the children with sugar. I instructed my inter. 
preters to collect every necessary information in their power to afford me."**

The intelligence procured from this tribe was discouraging. They stated, indeed, that the river ran towards the mid-day sun, and that at its mouth white people were building houses; but that the navigation was dangerous, and in three places absolutely impassable, owing to the falls and rapids. The nations through whose territories the route lay they represented as ferocious and malignant, especially their immediate neighbours, who dwelt in subterranean houses. Unappalled by this description, Mackenzie re-embarked, and he was accompanied by a small canoe, with two persons who consented to act as guides. Coming to a place where some savage-looking people were seen on a high ground, it was thought expedient to land, and an amicable interview took place, which led to important consequences. On explaining the object of the journey, one of the natives, of superior rank and intelligence, drew a sketch of the country on a piece of bark, appealing during his labour to his companions, and accompanying the rude but perfectly intelligible map by details as to their future voyage. He described the river as running to the east of south, receiving in its course many tributary streams, and broken every six or eight leagues by dangerous fulls and rapids, six of which were altogether impracticalle. The carrying-places he represented as of great length across mountains. He depicted the lands of three tribes in succession, who spoke different languages; and concluded by saying that beyond them he knew nothing of the country, except that it was still a great way to the sea, and that there was a lake of which the natives did not drink. $\dagger$

While the route by water was thus said to be impracticable, they asserted that the road across the country to the ocean was short in comparison, and lay along a valley free from wood, and frequently travelled. Other considerations combined to recommend this latter course to Mackenzie : only thirty days' provisions were left, and the supply procured by hunting was very precarious. The ammunition was nearly spent; and if the prosecution of the voyage appeared perilous, a return would have been equally so.

" Mackenzie's Travels, p. 244245.

† Ibid. p. 253. 
Under these circumstances, it was resolved to abandon the canoe, and to penetrate overland to the Western Ocean.

To arrive at the spot where they were to strike off across the country, it was necessary to return a considerable way up the river, - a service of great danger, owing to the shattered condition of the boat and the hostile dispositions of the natives, who were apt to change in an instant from the greatest friendliness to unmitigated rage and suspicion. The guides deserted them, and it became absolutely necessary to build a new canve. She proved better than the old one, and they at last reached the point whence they were to start overland. " "We carried on our backs," says Mackenzie, "four bags and a half of pemmican, weighing from eighty-five to ninety-five pounds each, a case with the instruments, a parcel of goods for presents, weighing ninety pounds, and a parcel containing ammunition of the same weight; each of the Cantdians had a burden of about ninety pounds, with a gun and ammunition, while the Indians had about forty-five pounds' weight of pemmican, besides their gun, - an obligation with which, owing to their having been treated with too much indulgence, they expressed themselves much dissatisfied. My own load and that of Mr. Mackay consisted of twenty-two pounds of pemmican, some rice, sugar, and other small articles, amounting to about seventy pounds, besides our arms and ammunition. The tube of my telescope was also slung acruss my shoulder; and owing to the low state of our piovisions, it was determined that we should content ourselves with two meals a-day."**

Thus laden, they struck into the woods, and travelled along a tolerably beaten path, arrived before night at some Indian tents, where they were joined by an elderly man and three ofher natives. The old man held in his hand a spear of European manufacture, like a sergennt's halberd, which he stated he had lately received from some people on the seacoast, to whom it had been given by white men. $\mathrm{He}$ added, that those heavily laden did not take more than six days to reach the tribes with whom he and his friends bartered their furs and skins for iron, and that thence it was scarcely two days' march to the sea. He recommended

* Mackenzie's Travels, p. 285. 
also that, while they retired to sleep, two young Indians should be sent forward to warn the different tribes whose territories they were approaching,--a precaution which had the best effects. Another pleasing distinction between their present hosts and the other savares whom they had passed soon presented itself: when the weary travellers lay down to rest the Indians took their station at a little distance, and began a song in a sweet plaintive tone, unaccompanied by any instrument, but with a nodulation exceedingly pleasing and solemn, not unlike that of church-music. The cirs cumstance may remind the reader of the descriptions of Arnerican music given by Mr. Meares and Captain Burney, which it strikingly corroborates.

Having procured two guides, they now proceeded through an open country sprinkled with cypresses, and joined a family of the natives. The father, on hearing their intention of penetrating to the ocean, pointed to one of his wives who was a native of the seacoast; her appearance differed from the females they had hitherto scen. She was of low stature, inclined to corpulency, with an oblong face, gray eyes, and a flattish nose. Her garments cousisted of a tunic covered with a robe of matted bark, fringed round the bottom with the beautiful fur of the sea-otter. She wore bracelets of brass, copper, and horn, while her hair was braided with large blue beads, and her ears and neck adorned with the same. With these people age seemed to be an object of great veneration; they carried an old woman by turns upon their backs, who was quite blind and infirm. The country appeared well peopled, and the natives, though at first alarmed, were soon conciliated by the guides. In some places they observed chains of small lakes, the valleys were verdant and watered with pleasant rivulets, and the scenery varied by groves of cypress and poplar, in which they were surprised to see no animals. The inhabitants indeed seemed to live exclusively on fish; and the people of one small settlemerat containing thirteen families were denominated, in the language of the country, Sloa-cuss. Dinais, or Red Fish Men. They were healthy looking, and more provident, cleanly, and comfortable than the neigh* bouring tribes.

One of Mackenzie's greatest and most frequent perplexities arose out of the sudden fits of cavrice and change of 
purpose which characterize most savages, but none more than the Americans. An example of this now occurred: the guides, upon whose fidelity the success of the expedition mainly depended, were advancing apparently in the most contented and friendly manner, when, in a moment, without uttering a word, they sprang forward, and disappeared in the woods, leaving the party, who were utterly unacquainted with the route, in a state bordering on despair.* Pushing forward, however, at a hazard, they perceived a house situated on a green spot by the edge of a wood, the smoke of which curled above the trees, intimating that it was inhabited. Mackenzie advanced alone, as his party were too much alarmed to second his intrepidity; and so intent were the inhabitants upon their household labours, that he approached unperceived. Nothing could exceed the terror and confusion occasioned by his sudden appearance. The women and children uttered piercing shrieks, and the only man about the place sprang out of a back-door with the rapidity of a wild-cat, and fled into the woods. Their dismay arose from the belief that they were surprised by enemies, and would be instantly put to death; an atrocity too common among the Indian tribes. The conduct of the man who had fled was amusing : by degrees he crept sufficiently near to watch the party; and on observing the kindness with which the women and children were treated, came cautiously within speaking distance. His eyes were still staring in his head. No assurances of the interpreters or the women could persuade him to return; no beads, knives, or presents of any kind had the effect of restoring his confidence. On being approached, he kept dodging about behind large trees, brandishing his bow and arrows, grinning hideously, and displaying a variety of strange antics, till at last, in one of his paroxysms, he dived into a thicket and disappeared. As suddenly he emerged in an opposite quarter, and becoming pacified, after a succession of parleys, agreed to accompany them as a guide.

On advancing from this station, they travelled over an elevated tract, and at length gained the summit of a hill, affording a view of a range of mountains covered with snow; which, according to the guide, terminated in the ocean. 
Passing along the borders of several small lakes, through a swampy country, they arrived at a lodge of natives, who received them with hospitality, and minutely scrutinized their appearance. The hair of the women was tied in large loose knots over the ears, and plaited with great neatness from the division of the head, so as to be included in the knots : some had their tresses adorned with beads, producing a very graceful effect; while the men were clothed in leather, their hair nicely combed, their complexion fair, and their skin cleanly. One young man was at least six feet four inches in height, with a prepossessing countenance, and affable and dignified manners. All, not excepting the children, carried a burden proportioned to their strength, consisting of beaver-coating and parchment, skins of the otter, marten, bear, and lynx, besides dressed moose-skins. These last they procured from the Rocky Mountain Indians; and for the purposes of trade the people of the seacoast preferred them to any others.

They now continued their journey through a beautiful valley, watered by a gentle rivulet, to a range of hills which they ascended till surrounded by snow so firm and compact that it crunched under their feet. Before them lay a stupendous mountain, whose summit, clad with the same spotless coronet, was partly lost in the clouds. Between it and the route they were to follow flowed a broad river; and descending from their present elevated ground, they plunged into woods of lofty and umbrageous cedars and alder-trees.* As they got lower into these primeval forests they were sensible of an entire cbange of climate. The guides pointed out to them, through the openings in the dark foliage, the river which flowed in the distance, and a village on its banks, while beneath their feet the ground was covered with berries of an excellent flavour, and completely ripe. The effect of sunset upon this noble scenery was strikingly beautiful; but their admiration was interrupted by the decampment of their guides, who, as the shades of evening began to fall, pushed forward at such a pace that the party were soon left without conductors in darkness and uncertainty. The men, who were much fatigued, now proposed to take up their quarters for the night ; but their indefatigas

* Mackenzle's Travels, p. 316, 317. 
ble leader groped his way forward, and at length, arriving at the edge of the wood, perceived the light of several fires. On coming up he entered a hut where the people were employed in cooking fish, threw down his burden, and shook hands with the inmates, who did not show any surprise, but gave him to understand by signs that he should go to a large house, erected on upright posts at some distance from the ground. A broad piece of timber, with steps cut in it, led to a scaffolding on a level with the floor; and ascending these, the traveller entered the apartment, passed three fires at equal distances in the middle of the room, and was cordially received by several people seated on a wide board at the upper end. Mackenzie took his place beside one whom, from his dignified look, he took to be the chief. "Soon after the rest of the party arrived, and placed themselves near him; upon which the chief arose and brought a quantity of roasted salmon. Mats were then spread, and the fish placed before them. When the meal was concluded, their host made signs which they supposed to convey a desire that they should sleep under the same roof with himself; but, as his meaning was not sufficiently plain, they prepared to bivouac without. Every thing was done to render their repose agreeable: a fire was kindled, boards placed that they might not sleep on the bare ground, and two delicate dishes of salmon-roes, beat up to the consistency of thick cream, and mixed with gooseberries and wood-sorrel, were brought for supper. On awaking in the morning, they found all their wants anticipated in the same hospitable manner; a fire was already blazing, a plentiful breakfast of roasted salmon and dried roes was provided, and a regale of raspberries, whortleberries, and gooseberries finished the meal.*

Salmon was so abundant in this river that the people had a constant supply. They had formed across the stream an embankment for placing fishing machines, which were disposed hoth above and below it. For some reason, however, they would permit no near inspection of the weir; but it appeared to be four feet above the water, and was constructed of alternate layers of gravel and small trees, fixed in a slanting position. Beneath it were placed machines into which the salmon fell in attempting to leap over; and on

* Mackenzie's Travels, p. 318-320. 
either side was a large timber frame six feet above the water, in which passages were left leading directly into the machines, while at the foot of the fall dipping nets were successfully employed. These people were observed to indulge an extreme superstition regarding their fish, refusing to taste flesh, and appearing to consider such an act as pollution. One of their dogs, having swallowed a bone which the travellers left, was beaten by his master till he disgorged it; and a bone of a deer being thrown into the river, a native dived, brought it up, consigned it to the fire, and carefully washed his hands. They would not lend their canoes for the use of the party, having observed some venison which they concluded was to be stowed on board; and they alleged that the fish would immediately smell it and leave them. Although generous in furnishing the strangers with as much roasted fish as they could consume, they would part with none in a raw state. They believed salmon to have an invincible antipathy to iron, and were afraid that, if given raw to the white men, they might take serious offence at being boiled in a vessel of this ominous metal. In other respects nothing eould exceed their friendliness; and at a neighhouing village belonging to the same tribe, the reception of Mackenzie was, if possible, still more kind. The son of the chief took from his own shoulders a beautiful robe of sea-otter skin, and threw it over the traveller, while the father expressed the utmost satisfaction in being presented with a pair of scissors to clip his beard,-a purpose to which, with the eager delight of a child, he instantly applied them.

The houses in this village were constructed in the same way as those already described, and remind us of the lively account given by Mr. Meares. At a little distance, Mackenzie observed some singular wooden buildings, which he conjectured to be temples. They consisted of oblong squares, about twenty feet high by eight broad, formed of thick cedar-planks beautifully joined. Upon these were painted hieroglyphics and figures of various animals, with a remarkable degree of correctness. In the midst of the village was a large building, at first supposed to be the unfinished frame-work of a house. Its dimensions, however, were far greater than those of an ordinary dwelling, the ground-plot being fifty feet by forty-five, each end formed 
by four stout posts, fixed perpendicularly in the earth. The corner posts were unornamented, and supported a beam of the whole length, having three intermediate props on each side. Two centre posts at each end, about two feet and a half in diameter, were carved into colossal human figures, supporting ridge-poles on their heads; the hands were placed on the knees, as if they felt difficulty in sustaining the weight, while the figures opposite to them stood in an easy attitude, with their hands resting on their hips. The posts, poles, and figures were painted red and black, and the carving was executed with a truth and boldness which bespoke no little advancement in sculpture.* In the mechanical arts they had arrived at considerable perfection. The chief's canoe was of cedar, forty-five feet long, four wide, and three feet and a half deep. It was painted black, and ornamented with drawings of various kinds of fish in white upon the dark ground, and the gunwale, both fore and aft, was neatly inlaid with the teeth of the sea-otter. In this vessel, according to the old chief's account, he undertook, about ten winters before, a voyage towards the mid-day sun, having with him forty of his subjects; on which occasion he met with two large vessels full of white men, the first he had seen, hy whom he was kindly received. Mackenzie very plausibly conjectured that these might be the ships of Captain Cook.

It was now the 18th of July, and, surrounded by friendly natives, with plenty of provisions, pleasant weather, and the anticipation of speedily reaching the great object of their wishes, they resumed their voyage in a large canoe, accompanied by four of the Indians. The navigation of the river, as they approached the ocean, was interrupted by rapids and cascades; but their skill in surmounting these impediments was now considerable, and on the 20 th, after a passage of thirty-six miles, they arrived at the mouth of the river, which discharges itself by various smalles channels into an arm of the Pacific Ocean. The purpose of the expedition was now completed, and its indefatigable leader painted in large characters, upon the face of the rock under whose shelter they had slept, this simple memorial: "Alexander Mackenzie, from Canada by land, the twenty-second of July, 
one thousand seven hundred and ninety-three." The inscription was only written in vermillion, and has probably long ago been washed away by the fury of the elements; but the name of Mackenzie is enduringly consecrated in the annais of discovery, as the first person who penetrated from sea to sea across the inmense continent of North America. His return by the same route it is unnecessary to pursue.

\section{CHAPTER IV.}

\section{Discoveries along the Shores of the Arctic Ocean.}

First and Second Expeditions of Franklin-Voyage of Captain Beechey.

Tre discoveries of Hearne and Mackenzie established the great fact that there is a northern coast in America, washed by the Arctic Ocean, which forms, in all probability, its continuous boundary; and they demonstrated the practicability of reaching this limit by passing over the vast plains which stretch northward from Canada and Hudson's Bay. The voyages of Captain Parrv, also, which have been already detailed,* fully corroborated this opinion; and it appeared evident that another expedition, properly conducted, might reach this shore, and more fully examine its whole extent. Such an expedition, accordingly, sailed from England on the 23d of May, 1820, its command being intrusted to Lieutenant, now Sir John Franklin, assisted by Dr. Richardson, an able mineralogist and natural historian. During the first portion of their journey, they followed the chain of the great lakes, instead of the more eastern track pursued by Hearne, and having descended the Coppermine River, arrived on 21st July, at the shore of the Arctic Ocean, where they commenced their career of discovery. Important as were the particulars of their survey, when considered in relation to the furtherance of geographical science, a minute detail is here unnecessary, and we shall attempt only a general sketch. 
Paddling along the coast to the eastward, on the inside of a crowded range of islands, they encamped on shore after a run of thirty-seven miles, in which they experienced little interruption, and saw only a small iceberg in the distance, though that beautiful luminous effulgence emitted from the congregated ices, and distinguished by the name of the ice-blink, was distinctly visible to the northward. The coast was found of moderate height, easy of access, and covered with vegetation; but the islands were rocky and barren, presenting high cliffs of a columnar structure. In continuing their voyage, the dangers which beset a navigator in these dreadful polar solitudes thickened gloomily around them : the coast became broken and steril, and at length rose into a high and rugged promontory, against which some large rnasses of ice had drifted, threatening destruction to their slender canoes. In attempting to round this cape the wind rose, an awful gloom involved the sky, and the thunder burst over their heads, compelling them to encamp till the storm subsided. They then, at the imminent risk of having the canoes crushed by the floating ice, doubled the dreary promontory, which they denominated Cape Barrow, and entered Detention Harbour, where they landed. Around them the land consisted of mountains of granite, rising abruptly from the water's edge, destitute of vegetation, and attaining an elevation of 1400 or 1500 feet ; seals and small deer were the only animals seen, and tine former were so shy that all attempts to approach within shot were unsuccessful. With the deer the hunters were more fortunate: but these were not numerous; and while the ice closed gradually around them, and their little stock of provisions, consisting of pemmican and cured beef, every day diminished, it was impossible not to regard their situation with uneasiness. Rounding Cape Kater, they entered Arctic Sound, and sent a party to explore a river upon the banks of which they expected to find an Esquimaux encampment. All, however, was silent, desolate, and deserted: even these hardy natives, bred amid the polar ices, had removed from so barren a spot, and the hunters returned with two small deer and a brown bear; the latter animal so lean and sickly-looking that the men declined eating it ; but the officers boiled its paws, and found them excellent.

Proceeding along the eastern shore of Arctic Sound, to 
which they gave the name of Bankes's Peninsula, the expedition made its painful way along a coast indented by bays, and in many places studded with islands, till on 10 th August they reached the open sea; and sailing, as they imagined, between the continent and a large island, found to their deep disappointment that, instead of an open channel, they were in the centre of a vast bay. The state of the expedition now called fur the most serious consideration upon the part of their commander. So much time had already been spent in exploring the sounds and inlets, that all hope of reaching Repulse Bay was vain; both canoes had sustained material injury; the fuel was expended; their provisions were sufficient only for three days; the appearances of the setting in of the arctic winter were too unequivocal to be mistaken; the deer, which had hitherto supplied them with fresh meat, would, it was well known, soon disappear ; the geese and other aquatic birds were already seen winging their way to the southward; while the men, who had up to this moment displayed the utmost courage, began to look disheartened, and to entertain serious apprehensions for their safety. Under these circumstances, Franklin, with the concurrence of his officers, determined not to endanger the lives of his people by a farther advance; and, after spending four days in a minute survey of the bay, it was resolved to return by Hood's River to Fort Enterprise. Franklin's researches, as far as prosecuted at this time, favoured the opinion of those who contended for the practicability of a north-west passage. It appeared probable that the coast ran east and west in the latitude assigned to Mackenzie's River, and little doubt could, in his opinion, be entertained regarding the existence of a continued sea in that direction. The portion over which they passed was navigable for vessels of any size; and the ice met with after quitting Detention Harbour would not have arrested a strong boat, while the chain of islands afforded shelter from all heavy seas, and there were good harbours at convenient distances. Having with much severe privation completed their course from Point Turnagain in Melville Bay to the entrance of Hood's Kiver, they ascended as high as the first rapid and encamped, terminating here their voyage on the Arctic Sea, during which they had gone over 650 geographical miles. 
On the prospect of commencing their land journey the Canadians could not conceal their satisfaction; and the evening previous to their departure was passed in talking over their past adventures, and congratulating each other in having at length turned their backs upon the sea,little anticipating that the most painful and hazardous portion of the expedition was yet to come. Before setting off, an assortment of iron materials, beads, looking-glasses, and other articles, were put up in a conspicuous situation for the Esquimaux, and the English union was planted on the loftiest sand-hill, where it might be seen by any ships passing in the offing. Here also was deposited in a tin box a letter containing an outline of the proceedings of the expedition, the latitude and longitude of the principal places, and the course intended to be pursued towards Slave Lake. They now proceeded up the river in their canoes, and though upon a short allowance of provisions, the produce of their nets and fowling-pieces furnished for a few days enough to ward off absolute want, but they were often on the very brink of it. Their progress was much interrupted by shoals and rapids, and one evening they encamped at the lower end of a narrow chasm, the walls of which were upwards of 200 feet high, and in some places only a few yards apart. Into this the river precipitates itself, forming two magnificent cascades, to which they gave the name of Wilberforce Falls. On taking a survey of its farther course from a neighbouring hill, it was discovered to be so rapid and shallow that all progress in the large canoes seemed impossible. Two smaller boats were therefore constructed; and on 1st September, they set off with the intention of proceeding in as direct a line as possible to the part of Point Lake opposite their spring encampment, - - distance which appeared comparatively trifling, being only 149 miles. Their luggage consisted of ammunition, nets, hatchets, ice-chisels, astronomical instruments, clothing-blankets, three kettles, and the two canoes, each so light as to be carried easily by a single man. But disaster attacked them in their very first stage. A storm of snow came on, accompanied by a high wind, against which it was difficult to carry the canoes, that were damaged by the falls of those who bore them. The ground was covered with small stones, and much pain was endured by the carriers, whose soft moose-skin shoes 
were soon cut through. The cold was intense; and on encamping they looked in vain for wood; a fire of moss was all they could procure, which served them to cook their supper, but gave so little heat that they were glad to creep under their blankets.*

Having ascended next morning one of the highest hills, they ascertained that the river took a westerly course, and Franklin, thinking that to follow it farther would lead to a more tedious journey than their exhausted strength could endure, determined to quit its banks and make directly for Point Lake. Emerging, therefore, from the valley, they crossed a barren country, varied only by marshy levels and small lakes. The weather was fine, but unfortunately no berry-bearing plants were found, the surface being covered in the more humid spots with a few grasses, and in other places with some gray melancholy lichens. On encamping, the last piece of pemmican, or pounded flesh, was distributed, with a little arrow-root, for supper. The evening was warm; but dark clouds overspread the sky, and they experienced those sudden alternations of climate which occur in the polar latitudes at this season. At midnight it rained in torrents; but towards morning a snowstorm arose, accompanied by a violent gale. During the whole day the storm continued, and not having the comfort of a fire the men remained in bed, but the tents were frozen; around them the snow had drifted to the depth of three feet, and even within lay several inches thick on their blankets. Though the storm had not abated any longer delay was impossible, for they knew every hour would increase the intensity of an arctic winter; and though faint from fasting, and with their clothes stiffened by frost, it was absolutely necessary to push forward. They suffered much in packing the frozen tents and bedclothes, and could hardly keep their hands out of their fur mittens. On attempting to move, Franklin was seized with a fainting fit, occasioned by hunger and exhaustion, and on recovering refused to eat a morsel of portable soup, which was immediately prepared for him, as it had to be drawn from the only remaining meal of the party. The people, however, kindly crowded round, and overcame his reluctance. The effect of eating was his rapid recovery; and the expedition moved on. 
Disaster now crowded on disaster. The wind rose so high, that those who carried the canoes were frequently blown down, and one of the boats was so much shattered as to be rendered unserviceable. The ground was covered with snow; and though the swamps were frozen, yet the ice was often not sufficiently strong; so that they plunged in knee-deep. A fire, however, was made of the bark and timbers of the broken canoe; and after having fasted three days, their last meal of portable soup and arrow-root was cooked. Each man's allowance at this melancholy dinner was exceedingly scanty ; but it allayed the pangs of hunger, and encouraged them to press forward at a quicker rate. They had now reached a more hilly country, strewed with large stones, and covered with gray lichen, well known to the Canadians by its name tripe de roche. In cases of extremity, it is boiled and eaten; but its taste is nauseous, its quality purgative, and it sometimes produces an intolerable griping and loathing. The party, not being aware of this, gathered a considerable quantity. A few partridges also had been shot; and at night some willows were dug up from under the snow, with which they lighted a fire and cooked their supper.

Next day they came to Cracroft's River, flowing to the westward over a channel of large stones, that rendered it impossible to cross in the canoe. No alternative was left but to attempt a precarious passage over some rocks at a rapid ; and in effecting this some of the men, losing their balance, slipped into the water. They were instantly rescued by their companions ; but so intense was the frost, that their drenched clothes became caked with ice, and they suffered much during the remainder of the day's march. The hunters had fallen in with some partridges, which they shot, and they found enough of roots to make a fire; so that their supper, though scanty, was comparatively comfortable. Next morning they pushed forward with ardour, and passed the river Congecathawhachaga of Mr. Hearne. The country which lay before them was hilly, and covered with snow to a great depth. The sides of the hills were traversed by sharp angular rocks, where the drifted snow, filling up the interstices, presented a smooth but fallacious surface, which often gave way and precipitated them into the chasms with their heary loads. In this painful and arduous manner they struggled 
forwaid several days, feeding on the tripe de roche, which was so frozen to the rocks that their hands were benumbed before a meal could be collected, and so destitute of nutritive juices that it allayed hunger only for a very short time. $\Lambda t$ length reaching the summit of a hill, they, to their great delight, beheld a herd of musk-oxen feeding in the valley below; an instant halt was made, the best hunters were called out, and while they proceeded with extreme caution in a circuitous route, their companions watched their proceedings with intense anxiety. When near enough to open their fire, the report reverberated through the hills, and one of the largest cows was seen to fall. "This success," says Franklin, in that simple and beautiful account of his journey which any change of language would only weaken, "infused spirit into our starving party. The contents of its stomach were devoured upon the spot; and the raw intestines, which were next attacked, were pronounced by the most delicate of the party to be excellent. A few willows, whose tops were seen peeping through the snow in the bottom of the valley, were quickly grubbed, the tents pitched, and supper cooked and devoured with avidity. It was the sixth day since we had had a good meal. I do not think that we witnessed, through the course of our journey, a more striking proof of the wise dispensation of the Almighty, and of the weakness of our own jurlgment, than on this day. We had considered the dense fog which prevailed throughout the morning as almost the greatest inconvenience which could have befallen us, since it rendered the air extremely cold, and prevented us from distinguishing any distant object towards which our course could be directed. Yet this very darkness enabled the party to get to the top of the hill, which bounded the valley wherein the musk-oxen were grazing, without being perceived. Had the herd discovered us and taken alarm, our hunters, in their present state of debility, would in all probability have failed in approaching them." $*$

On the following day a strong southerly wind blowing with a snow-drift, they took a day's rest, and as only enough remained of the musk-ox to serve for two days, they contented themselves with a single meal. Next morning,

* Franklin's Journey, vol. iv. p. 13, small edition of 1829 
though the gale had not diminished, they pushed forward, and notwithstanding their rest and recent supply of animal food, the whole party felt greater weakness than they had hitherto experienced. The weather was hazy, but after an hour's march the sky cleared, and they found themselves on the borders of a lake, of which they could not discern the termination in either direction. In these circumstances they travelled along its banks to the westward, in search of a crossing-place. Credit, one of the Canadians, left the party in hopes of falling in with deer, but did not return; and on encamping in the evening, hungry and fatigued, they had to divide for supper a single partridge and some tripe de roche. This weed from the first had been unpalatable, but now became insupportably nauseous, and began in many to produce severe pains and bowel complaints, especially in $\mathrm{Mr}$. Hood, one of the young officers attached to the expedition. This solitary partridge was the last morsel of animal food that remained; and they turned with deep anxiety to the hope of catching some fish in the lake, but discovered that the persons intrusted with them had improvidently thrown away three of the nets and burnt the floats on leaving Hood's River. Things now began to look very gloomy ; and as the men were daily getting weaker, it was judged expedient to lighten their burdens of every thing except ammunition, clothing, and the instruments necessary to guide them on their way. The dipping-needle, the azimuth compass, the magnet, a large thermometer, and the few books they carried were therefore deposited at this encampment, after they had torn out from these last the tables necessary for working the latitude and longitude. Rewards also were promised by Franklin to such of the party as should kill any animals, and in the morning they prepared to go forward.

At this moment a fine trait of disinterestedness occurred: as the officers assembled round a small fire, enduring an intense degree of hunger which they had no means of satisfying, Perrault, one of the Canadians, presented each of them with a piece of meat out of a little store which he had saved from his allowance. "It was received," says Franklin, "with great thankfulness, and such an instance of self-denial and kindness filled our eyes with tears." Pressing forward to a river issuing from the lake, they met their comrade Credit, and received the joyful intelligence 
that he had killed two deer. One of these was immediately cut up and prepared for breakfast ; and having sent some of the party for the other, the rest proceeded down the river, which was about 300 yards broad, in search of a place to cross. Having chosen a spot where the current was smooth, immediately above a rapid, Franklin and two Canadian boatmen, St. Germain and Belanger, pushed from the shore. The breeze was fresh, and the current stronger than they imagined, so that they approached the very edge of the rapid; and Belanger, employing his paddle to steady the canoe, lost his balance, and overset the bark in the middle of it. The party clung to its side, and reaching a rock where the stream was but waist-deep, kept their footing till the canoe was emptied of water, after which Belanger held it steady while St. Germain replaced Franklin in it and dexteronsly leaped in himself. Such was their situation, that if the man who stood on the rock had raised his foot they would have been lost. His friends therefore were compelled to leave him, and after a second disaster, in which the canoe struck, and was as expeditiously righted as before, they reached the opposite bank. Meanwhile Belanger suffered extremely, immersed to his middle, and enduring intense cold. He called piteously for relief, and St. Germain, re-embarking, attempted to reach him, but was hurried down the rapid, and on coming ashore was so benumbed as to be incapable of furiher exertion. A second effort, but equally unsuccessful, was made by Adam: they then tried to carry out a line formed of the slings of the men's loads, but it broke, and was carried down the stream. At last, when he was almost exhausted, the canoe reached him with a small cord of one of the remaining nets, and he was dragged to shore quite insensible. On being stripped, rolled in blankets, and put to bed between two men, he recovered. During these operations Franklin was left alone upon the bank, and it seemed a matter of the utmost doubt whether he should be ever rejoined by his companions. "It is impossible," says he, " to describe my sensations as I witnessed the various unsuccessful attempts to relieve Belanger. The distance prevented my seeing distinctly what was going on, and I continued pacing up and down the rock on which I stood, regardless of the coldness of my drenched and stiffen ing garments. The canoe, in every attempt to reach him, 
was hurried down the rapid, and was lost to view among the rocky islets with a fury which seemed to threaten instant destruction; once indeed I fancied that I saw it overwhelmed in the waves; such an event would have been fatal to the whole party. Separated as I was from my companions, without gun, ammunition, hatchet, or the means of making a fire, and in wet clothes, my doom would have been speedily sealed. My companions, too, driven to the necessity of coasting the lake, must have sunk under the fatigue of rounding its innumerable arms and bays, which, as we learned afterward from the Indians, are extensive. By the goodness of Providence, however, we were spared at that time, and some of us have been permitted to offer up our thanksgiving in a civilized land for the signal deliverance we then and afterward experienced." $* *$

On setting out next morning, Perrault brought in a fine male deer, which raised the spirits of the party, as it secured them in provisions for two days; and they trusted to support themselves for a third on the skin which they carried with them. Having ascended the Willingham Mountains, they entered upon a rugged country intersected by deep ravines, the passage of which was so difficult that they could only make ten miles with great fatigue. The deer was now picked to the last morsel, and they ate pieces of the singed hide with a little tripe de roche. At other times this meal might have sufficed; but, exhausted by slender food and continued toil, their appetites had become ravenous. Hitherto events had been so mercifully ordered that in their utmost need some little supply in the tripe de roche had never failed them; but it was the will of God that their confidence should be yet more strongly tried; for they now entered upon a level country covered with snow, where even this miserable lichen was no longer to be found; and a bed of Iceland moss, which was boiled for supper, proved so bitter that none of the party, though enduring the extremities of hunger, could taste more than a few spoonfuls. Another distress now attacked them: the intensity of the cold increased, while they became less fit to endure it. Their blankets did not suffice to keep them warm, and the slightest breeze pierced through their debilitated frames. "The 
reader," says Franklin, "will probably be desirous to know how we passed our time in such a comfortless situation. The first operation after encamping was to thaw our frozen shoes, if a sufficient fire could be made; dry ones were then put on. Each person then wrote his notes of the daily occurrences, and evening prayers were read. As soon as supper was prepared it was eaten, generally in the dark, and we went to bed and kept up a cheerful conversation until our blankets were thawed by the heat of our bodies, and we had gathered sufficient warmth to enable us to fall asleep. On many nights we had not even the luxury of going to bed in dry clothes; for, when the fire was insufficient to dry our shoes, we dared not venture to pull them off, lest they should freeze so hard as to be unfit to put on in the morn ing, and therefore inconvenient to carry." *

Hunger, fatigue, and disappointment began now to have a calamitous effect upon the tempers of the men. One, who carried the canoe, after several severe falls, threw down his burden, and obstinately refused to resume it. It was accordingly given to another, who proved stronger, and pushed forward at so rapid a rate that Mr. Hood, whose weakness was now extreme, could not keep up with them; and as Franklin attempted to pursue and stop them, the whole party were separated. Dr. Richardson, who had remained behind to gather tripe de roche, joined him, and on advancing they foind the men encamped among some willows, where they had found some pieces of skin and a few bones of deer which had been devoured by the wolves. On these they had made a meal, having burnt and pounded the bones, boiled the skin, and added their old shoes to the mess. With this no fault could be found; but on questioning the person to whom the canoe had been intrusted, it was discovered that he had left the boat behind, it having, as he said, been broken by a fall and rendered entirely useless.

To the infatuated obstinacy of the men in refusing to retrace their steps and fetch it, even in its shattered state, is to be ascribed much of the distress of their subsequent journey. Every argument and entreaty seemed entirely thrown away; and they had apparently lost all hope of being preserved. When the hunters, who had been out for some

* Franklin's Journey, p. 414. 
time, did not make their appearance, they became furious at the idea of having been deserted, and throwing down their bundles, declared they would follow them at all hazards, and leave the weakest to keep up as they best could. The remonstrances of the officers at length opened their minds to the madness of such a scheme; and on encamping in the evening, they found some pines seven or eight feet high, which furnished a comfortable fire, when they made their supper on tripe de roche. Next morning a herd of deer came in sight, and they killed five,-a supply which, considering the extremity of hunger and despair to which they were reduced, was especially providential. It was evident that $\mathrm{He}$, without whom not a sparrow falls to the ground, was with them in their extremity of distress; and, casting themselves upon his care, every heart expanded with hope and gratitude.

The Canadians now earnestly petitioned for a day's rest. They pleaded their recent sufterings, and that the enjoy ment of two substantial meals, after eight days' famine, would enable them to press forward more vigorously. The fiesh, the skins, and even the stomachs of the deer were accordingly equally divided among the party, and some of them suffered severely from too free an indulgence in the use of this food after so long an abstinence. Next morning the party resumed their journey, and after a walk of three miles came to the Coppermine River. Its current was strong, but with a canoe there would have been no difficulty in crossing; and the reckless folly of the men in abandoning their only means of transport was now brought strongly to their mind. No ford could be discovered, and the plan was suggested of framing a vessel of willows, covered with the canvass of the tent; but the most experienced boatmen declared the willows were too small to bear the weight; and no pines could be found. Nothing remained but to resume their march along the borders of the lake; and looking out eagerly, but in vain, for some fordable place, they encamped at the east end. Anxious to adopt every possible means for preserving the party, Franklin sent Mr. Back forward with the interpreters to hunt. He was directed to halt at the first pines and construct a raft; and if his liunters had killed animals sufficient to provision them, he was to cross immediately and send the Indians with supplies of meat to the party behind. 
At this time it was discovered that two of the men had stolen part of the officers' provision, though it had been doled ont with the strictest impartiality, and they saw their leaders suffiring more acutely than themselves. To punish this was impossible, except by the threat that they should forfeit their wages, which produced little effect. Despondency had deeply seized upon the party, and in the morning strict orders could not prevent them from straggling in search of the remains of animals; in consequence of which much time was lost in halting, and ammunition in firing guns to collect them. The snow, however, had disappeared, and pressing forward with more alacrity, they came to an arm of the lake running north-east. The idea of making the long circuit round it was distressing, and having halted to consult what was to be done, some one discovered in a cliff the carcass of a deer which had fallen into a chasm. It was quite putrid, but even in that state appeared delicious, and a fire being kindled, a large portion was rapidly de voured; while the men, cheered by this unexpected breakfist, regained their confidence, and requested leave to return to the rapid, insisting on the practicability of making a sufficiently strong raft of willows, though they had formerly pronounced it impossible. Their advice was followed; and having sent off Augustus, one of the interpreters, to inform Mr. Back of this change of plan, they commenced their retrourade movement, and encamped at night in a deep valley among some large willows, where they supped on the remains of the putrid deer.

Next day they regained the rapids, commenced cutting willows for the raft, and a reward of 300 livres was promised by Franklin to the person who should convey a line across the river strong enough to manage the raft and transport the party. The willows when cut were bound into fagots, and the work completed; but the greenness of the wood rendered it heavy, and incapable of supporting more than one man at a time. Still they hoped to be able to cross; but all depended on getting a line carried to the opposite bank, through a current 130 yards wide, strong, deep, and intensely cold. Belanger and Benoit, the two strongest men of the party, repeatedly attempted to take the raft over, but for want of oars were driven back. The tent-staves were then tied together, and formed a strong.pole; but it 
was not long enough to reach the bottom even at a short distance from the shore. Dr. Richardson next produced a paddle he had brought from the coast, but which was found not powerful enough to impel the raft against a strong breeze. The failure of every attempt occasioned a deep despondency, which threatened to have the most fatal effects, when Dr. Richardson, with a disinterested courage that made him forget his own wealnness, threw off his upper garments, and attempted to swim with a rope to the opposite bank. Plunging in with the line round his middle ho at first made some way, but the extreme cold was too much for him, and in a few moments his arms became powerless; still, being an expert swimmer, he not only kept himself afloat, but made way by turning on his back and using his legs, so that he had nearly reached the other side, when, to the inexpressible anguish of those who watched his progress, his limbs became benumbed, and he sank. All hands now hauled on the line, and drew him ashore almost lifeless; but placed before a fire of willows, and stripped of his wet clothes, he gradually revived enough to give directions as to the mode of treating him. His thin and emaciated limbs, which were now exposed to view, produced an involuntary exclamation of compassion and surprise:- "Ah, que nous sommes maigres!" said the French Canadians; but it is probable that few of them would have presented so gaunt and attenuated an appearance as the brave and excellent man who had thus nearly fallen a sacrifice to his humanity, for it was discovered abont this time that the hunters were in the practice of withholding the game which they shot, and devouring it in secret.*

Soon after this the party were joined by Mr. Back, who had traced the lake about fifteen miles farther up without discovering any place where it was possible to get across; and towards evening Credit, who had been out hunting, returned without any game of his own killing; but brought the antlers and back-bone of a deer shot during the summer. These relics had been already picked clean by the wolves and birds of prey, but the marrow remained in the spine; and though completely putrid, and so acrid as to excoriate the lips, it was not the less acceptable. The bones were 
rendered friable by burning, and the whole eagerly devoured. St. Germain, one of the voyagers, now suggested that a canoe might be made of the painted canvass used to wrap up the bedding, and offered to construct it upon a framework of willows. For this purpose he and Adam removed to a clump of willows, while another party proceecied to the spot where they had encamped on the $25 \mathrm{th}$, to collect pitch among the small pines to pay over the seams. A snowstorm at this moment came on, and the sufferings of the men hourly increasing, a decp gloom settled upon their spirits. Mr. Hood was by this time reduced to a perfect shadow; Mr. Back required the support of a stick; Dr. Richardson was laine; and Franklin so feeble, that, after a struggle of three hours, he found himself utterly unable to reach the spot where St. Germain was at work, a distance of only three-quarters of a mile, and returned completely exhausted. The Canadian voyagers had now fallen into a state of despondency which bordered on despair, and, indifferent to their fate, refused to make the slightest exertion. The officers were unable to undergo the labour of gathering the tripe de roche, and Samandré, the cook, sullenly declined continuing his labours. At this miserable crisis the conduct of John Hepburn, an English sailor, was especially admirable, presenting a striking contrast to the gloomy selfishness of the Canadians. His firm reliance on the watchful goodness of God, and a cheerful resignation to his will, never for a moment forsook him; and, animated by this blessed principle, his strength appeared to be preserved as the means of saving the party. He collected the tripe de roche for the officers' mess, cooked and served it out, and showed the most indefatigable zeal in his efforts to alleviate their sufferings.

A gleam of hope at length arose when St. Germain completed the canoe. It was impossible not to feel that their last chance of escape seemed to hang upon this little bark; -would it prove sufficient for its purpose? or, constructed of such wretched materials, would it not at once sink to the bottom? Amid this conflict of contending emotions it was launched on the river, and every heart bounded with exultation when it floated, and St. Germain transported himself to the opposite side. It was drawn back, and, one by one, the whole party were ferried over, though, from the leaky state 
of the little bark, their garments and bedding were com. pletely drenched. Franklin inmediately despatched Mr. Back and three men to push on to Fort Enterprise in search of the Indians, while he himself followed with the rest.

Nothing could exceed the joy of the Canadian voyagers at this unlooked-for deliverance. Their spirits rose from the deepest despondency into tumultuous exultation. They shook the officers by the hand, cried out that their worst difficulties were at an end, and expressed a confident hope of being able to reach Fort Enterprise in the course of a few days, - a boisterous and sudden confidence, to which the silent gratitude and quiet resolution of the pious Hepburn presented a striking contrast.

Their tents and bedelothes were so much frozen, and the men, who had kindlei a small fire, so weary, that it was eight in the morning before the bundles were packed, and the party set forward. They travelled in single files, each at a small distance from his neighbour. Mr. Hood, who was now nearly exhausted, was obliged to walk at a gentle pace in the rear, Dr. Richardson kindly keeping beside him; while Franklin led the foremost men, that he might make them halt occasionally till the stragglers came up. Credit, hitherto one of their most active hunters, became lamentably weak from the effects of tripe de roche on his constitution, and Vaillant, from the same cause, was getting daily more emaciated. They only advanced six miles during the day, and at night satisfied the cravings of hunger by a small quantity of tripe de roche mixed up with some scraps of roasted leather. During the night the wind increased to a strong gale, which continuing next day, besides being piercingly cold, filled the atmosphere with a thick snow-drift. Having boiled and eaten the remains of their old shoes, and every shred of leather which could be picked up, they set forward at nine over blesk hills separated by equally barren valleys.

In this manner they journeyed till noon, not without much straggling and frequent halts, at which time Samandré came up with the melancholy news that Credit and Vaillant had dropped down, and were utterly unable to proceed. Dr. Richardson went back, and discovering Vaillant about a mile and a half in the rear, assured him that a fire was kindled a little way on, and that he would recover if he could 
but reach it; the poor fellow struggled up on his feet, and feebly tried to advance, but fell down every step in the deep snow. Leaving him, Dr. Richardson retraced his steps about a mile farther in a fruitless search for Credit. In returning he passed Vaillant, who had fallen down, utterly unable to renew his efforts to rejoin the party. Belanger went back to carry his burden and assist him to the fire; but the cold had produced such a numbness that he could not speak or make the slightest exertion. The stoutest of the party were now implored to make a last effort to transport him to the fire, but declared themselves utterly unable for the task. They eagerly requested leave to throw down their loads, and proceed with the utmost speed to Fort Enterprise,- a scheme projected in the despair of the moment, and which must have brought destruction upon the whole.

Matters had now reached a dreadful crisis ; it was necessary to come to an immediate decision regarding their ultimate measures, and a pian proposed by Mr. Hood and Dr. Richardson was adopted. These gentlemen consented to remain with a single attendant at the first spot where there were sufficient firewood and tripe de roche for ten days' consumption, while Franklin and the rest were to proceed with all expedition to Fort Enterprise, and send immediate assistance. This scheme promised to relieve them of a considerable portion of their burdens,--for one of the tents and various other articles werc to be left; and it gave poor Credit and Vaillant a fairer opportunity, should they revive, of regaining their companions. On the resolution being communicated to the men, they were cheered with the prospect of an alleviation of their misery, and pressed forward in search of a convenient spot for the proposed separation. Near nightfall they encamped under the lee of a hill among some willows, which furnished a small fire, but not sufficiently strong to thaw their frozen clothes; and no tripe de roche having been found during the day, they lay down hungry, cold, and full of the gloomiest apprehensions, while sleep fled from their eyclids, and the images of their dying companions rose before their imagination in colours which made them shudder for a fate that might so soon become their own.* Next morning the weather providentially was

* Franklin's Journey, p. 431, 432 
mild, and setting out at nine they arrived towards noon at a thicket of willows, in the neighbourhood of some rocks bearing a pretty full supply of tripe de roche. Here Dr. Richardson and $\mathrm{Mr}$. Hood determined to remain. The tent was pitched, a barrel of ammunition and other articles were deposited, and Hepburn, who volunteered the service, was appointed to continue with them. The rest of the party now had only to carry a single tent, the ammunition, and the officers' journals, in addition to their own clothes and a single blanket for Captain Franklin. When all was ready, the whole party united in thanksgiving and prayers to Almighty God for their mutual preservation, and separated with the melancholy reflection that it might in all probability be the last time they should ever again meet in this world.

On leaving their friends Captain Franklin and his party descended into a more level country; but the snow lay so deep, and they were so little able to wade through it that they encamped, after a painful march of only four miles and a half, in which Belanger and Michel, an Iroquois, were left far behind, yet still struggling forward. In the evening they came in dreadfully exhausted, and Belanger, till now one of the strongest of the party, could not refrain from tears as he declared he was totally unable to proceed, and implored permission to return to Dr. Richardson and Mr. Hood. Michel made the same request, and it was agreed that they should do so. The cold of the night was excessive, and the men were so weak that they could not raise the tert; from its weight it was impossible to transport it from place to place, and it was cut up, the canvass serving them for a covering; but, though they lay close together, the intense frost deprived them of sleep. Having no tripe de roche, they had supped upon an infusion of the Labrador tea-plant, with a few morsels of burnt leather. Michel and Belanger, being apparently more exhausted in the morning than overnight, were left, while the rest moved forward. After a very short progress Perrault was attacked with a fit of dizziness; but, on halting a little, again proposed to proceed. In ten minutes, however, he sank down, and, weeping aloud, declared his total inability to go on. He was accordingly advised to rejoin Michel and Belanger,-a proposal in which he acquiesced. These examples of the total failure of the strongest in the party had a very unfavourable effect on the 
spirits of the rest, and the exertion of wading through the snow and crossing a lake on the ice, where they were frequently blown down, was so severe, that Fontano, after having repeatedly fallen, piteously complained that he was utterly unable to go farther. Being not two miles from the others, it was thought best that he also should attempt to rejoin them; ${ }^{*}$ and as he was much beloved, the parting was very distressing. They watched him for some time, and were comforted by seeing that, though his progress was very slow, he kept his feet better than before.

The whole party was now reduced to five persons, Captain Franklin, Adam, Peltier, Benoit, and Samandré, the interpreter Augustus having pressed forward by himself during the late frequent hilts. They made that day only four miles and a half, and encamped for the night under a rock, supping again on an infusion of the Labrador tea-plant and some shreds of boiled leather. The evening was comparatively mild, the breeze light, and having the comfort of a fire, they enjoyed some sleep. This was of infinite advantage; it gave them new spirits, which were further invigorated by a breakfast of tripe de roche, this being the fourth day since they had a regular meal. On reaching Marten Lake they found it frozen over,- - circumstance which they knew would enable them to walk upon the ice straight to Fort Enterprise.

It may be easily imagined what were the sensations of the party in approaching the spot which they trusted would be the end of all their toils and privations. From the arrangements previously made, it was judged certain that they would here find relief, and be able to send assistance to their unfortunate companions. It was a spot where they had enjoyed, at a former period of the expedition, the greatest comfort; but it was possible, though they scarcely permitted themselves to contemplate so dreadful an idea, that circumstances might have occurred to defeat their present expectations. On approaching the house their minds were strongly agitated between hope and fear, and, contrary to their usual custom, they advanced in silence. At length they reached it, and their worst apprehensions were realized. It was completely desolate. No provisions had been depos-

* Franklin's Journey, p. 436, 437. 
ited-no trace of Indians could be discovered-no letter lay there from Mr. Wentzel to inform them where the Indians might be found. On entering, a mute despair seized the party. They gazed on the cold hearth, comfortless walls, and broken sashes, through which the wind and snow penetrated, and, awakening to a full sense of the horrors of their situation, burst into tears.* On recovering a little, and looking round with more attention, a note was found from Mr. Back, stating that having two days before this reached the house, he had proceeded in search of the Indians; but it described his party as so debilitated that it was doubtful whether they would be able to reach Fort Providence. The sufferings endured by this meritorious officer and his little party, one of whom was frozen to death, were equally dreadful with those which fell to the share of his excellent commander. $\dagger$

The poor sufferers, thus grievously disappointed, now examined the deserted habitation for the means of subsistence, and found several deer-skins thrown away during their former residence at, the fort. The heaps of ashes were carefully raked, and a considerable collection of bones discovered, which were hoarded up for the purpose of being pounded and manufactured into soup. The parchment originally employed instead of glass had been torn from the windows, and the place was exposed to all the inclemency of an arctic winter; but they succeeded in filling the sashes with loose boards, and as the temperature of the outer air was now from $15^{\circ}$ to $20^{\circ}$ below zero, this precaution was especially necessary. To procure water they melted the frozen lumps of snow, and the flooring of the neighbouring apartment was broken up for fuel.

Having completed these arrangements, they assembled round the fire, and were busy singeing the hair off a deerskin, when they were cheered by the entrance of the interpreter, who had made his way to the fort by a different route, through a country he had never traversed before. Though by far the strongest of the party, he was now so enfeebled by famine that he could not follow two deer which he had seen on his way. Next morning there was a heavy gale

* Franklin's Journey, p. 438, 439.

$\uparrow$ See Mr. Bacli's interesting Narrative, Franklin's Journcy, p. $4 \%$. 
from the south-east, and the snow drifted so thick that no one ventured abroad. On the evening of the succeeding day, a figure covered with ice, benumbed with cold, and almost speechless, staggered into the house : it was one of the Canadians who had been despatched with a note by $\mathrm{Mr}$. Back, and having fallen into a rapid, narrowly escaped being drowned.* To change his dress, wrap him in warm blankets, and pour some soup over his throat, was their first care; and after a little he revived enough to answer the anxious questions with which he was assailed. From his replies but little comfort was derived. Mr. Back had seen no trace of the Indians, and the messenger's recollection appeared confused with regard to the part of the country where he had left his officer, who, as he stated, intended to proceed to the spot where the Indian chief Akaitcho had encamped last summer,-a distance of about thirty miles. Thither he proposed to follow when he was a little recruited; and, though dissuaded from the attempt, persisted that as the track was beaten he would 'e able to make it out, and to convey intelligence of the situation of Captain Franklin's party. Accordingly, the fifth day after his arrival, he departed from the fort with a small supply of singed hide.

Not long after, Adam, one of the five men who now remained with Captain Franklin, became so ill that he was utterly incapable of movine, and it was discovered that he had been for some time afflicted with cedematous swellings in various parts of his body, which he had hitherto generously concealed, from a wish not to impede the movements of his companions. As it was impossible for this poor man to travel, it was necessary to abandon the original intention of proceeding with the whole party to Fort Providence, and Peltier and Samandre, who were in almost as weak a state, having expressed a wish to remain with Adam, Captain Franklin, along with Augustus and Benoit, determined to press on to Fort Providence, and to send relief to their companions by the first party of Indians they should meet.

Having accordingly given directions regarding the journals and charts which were left in their custody, and the best mode of forwarding succour to Mr. Hood and Dr. Richardson, Franklin set forward with his two attendants; but so feeble

* Franklin's Journey, p. 440, 441. 


\section{FRANKLIN JOINED BY HIS FRIENDS,}

had they become, that the distance accomplished in six hours was only four miles. They encamped on the borders of Round Rock Lake, and, unable to find any tripe de roche, made their supper upon fried deer-skin. The night proved intensely cold, and although they crept as close to each other as possible, they shivered in every limb, and the wind pierced through their famished frames.* Next morning was mild, and they set out early, but had scarce proceeded a few yards, when Franklin fell between two rocks and broke his snow-shoes, an accident which incapacitated hirn from keeping up with Benoit and Augustus. In a very short time his attempt to press forward completely exhausted him ; and as the only hope of preserving the lives of the party appeared to rest on their speedily reaching Fort Providence, he determined, rather than retard them, to retrace his steps to the house while they proceeded for assistance. Calling a moment's halt, he addressed one note to Mr. Back, requesting an immediate supply of meat from Rein-deer Lake, and another to the commandant at Fort Providence, with urgent entreaties for assistance. This done, Augustus and Benoit resumed their journey, and Franklin returned to the house.

On arriving he found Adam, Samandré, and Peltier still alive ; but the two first, whose minds seemed quite enfeebled, could not be prevailed on to leave their bed, and their nervous weakness was so great that they scarcely ceased shedding tears all day. It was even with difficulty that they were prevailed on to take any nourishment; and the labour of cutting and carrying fuel, gathering the tripe de roche, and cooking fell entirely upon Franklin and Peltier. The frost was now so severe that it was evident this lichen would soon be bound up in ice, and as their strength daily declined, every exertion became irksome. When once seated, it required a painful effort to rise up, and not unfrequently they had to lift each other from their chairs. This miserable condition could not last long. Peltier soon became almost incapable of holding the hatchet; the bone-soup had grown so acrid as to corrode the inside of their mouths; the tripe de roche, covered with ice, defied all efforts to detach it from the rock; and though the rein-deer sported on the banks of

* Franklin's Journey, p. 444. 
the river, no one had strength to go after them, or to hold a gun so steadily as to secure an aim

Still the hopes and cheerfulness of Franklin did not desert him. From his knowledge of the places mostly frequented at that season by the Indians, he was sanguine as to the likelihood of their being found; and their speedy arrival formed a constant subject of conversation. At length, on the evening of the $29 \mathrm{th}$, when talking of this long lookedfor relief, and sitting round the fire, Peltier suddenly leaped nu and uttered a joyful exclamation, imagining he heard the bustle of the Indians in the adjoining room. It was not the Indians, however, but Dr. Richardson and Hepburn, who came in each carrying his bundle. The meeting was one of mingled joy and sorrow. Poor Hood's absence was instantly perceived, and their saddest anticipations were confirmed by Dr. Richardson declaring that this young officer anc' Michel were dead, and that neither Perrault nor Fontano had reached the tent, or been heard of. Such news could not fail to create despondency. Alı were shocked at the emaciated countenances and hollow voices of Dr. Richardson and his companion, while Captain Franklin and his fellow-sufferers, having become gradually accustomed to the dreadful effects of famine upon each other, were not aware that, to the eyes of their friends who had just arrived, the alteration upon themselves was equally melancholy. "The doctor," says Franklin, "particularly remarked the sepulchral tone of our voices, which he requested us to make more cheerful if possible, not aware that his own partook of the same key."*

The arrival of these friends, however, was soon attended with a favourable change. Though greatly reduced, they were still in a better condition than their unfortunate com panions, and it was not long till Hepburn shot a partridge. Dr. Richardson speedily tore off the feathers, and having held it for a few minutes at the fire divided it into six pieces: Franklin and his companions ravenously devoured their portions, "being the first morsel of flesh that any of them had tasted for thirty-one days," and Dr. Richardson cheered them with the prospect that Hepburn might possibly bring in a deer in his next expedition. The counsels 
and example of this pious and intelligent man produced the best effects on the spirits of the party. He had brought with him his Testament and Prayer-book; and by reading portions of Scripture appropriate to their situation, and encouraging them to join in prayer and thanksgiving, he led them to the only Source whence, under the awful circumstances in which they were placed, they could derive hope or consolation. He taught them the necessity of exertion, whatever pain it might at first cost; roused them to pay some attention to the cleanliness of their apartment, and insisted particularly that during the day they should roll up their blankets, which they had been in the practice of leaving beside the fire where they slept. Their several tasks were now allotted to each; Hepburn and Richardson went out in search of deer; while Franklin, being unable to walk far, remained nearer the house, and digged under the snow for skins, which, during their former happy winter residence at this station, when they killed and ate abundance of game, were thrown away as useless, but now, in their almost putrid state, formed their principal support. The cutting of firewood was intrusted to Peltier and Samandré; but both were so weak and dispirited that it was generally performed by Hepburn on his return from hunting; as for Adam, his legs were still so severely swollen that he kept his bed, though an operation performed by Dr. Richardson gave him some ease. In the midst of these necessary cares, all seemed for a while to dread approaching the sub ject of Hood and Michel's death; but at length one even ing, on the return of the doctor from hunting, and after having despatched their usual supper of singed skin and bone-soup, they requested him to relate the particulars, and a more aftlicting, or in some respects a more terrific story, as it appears in his published narrative, could not well be conceived.

He stated, that after being left by Captain Franklin they remained beside the fire as long as it lasted. Having no tripe de roche, they supped on an infusion of the country tea-plant, which was grateful from its warmth, but aflorded no nourishment, and retired to rest. Next day proved stormy, and the snow being so deep that a fire could not be kindled with the green willows, they lay in bed reading some religious books with which the party had been fur- 
nished liefore leaving England by the affectionate and pious care of a lady. "They proved," says Richardson, " of incalculable benefit to us. We read portions of them to each other as we lay in bed, in addition to the morning and evening service, and found that they inspired us on each perusal with so strong a sense of the omnipresence of a beneficent God, that our situation in these wilds appeared no longer destitute; and we conversed not only with calmness but with cheerfulness, detailing with unrestrained confidence the past events of our lives, and dwelling with hope upon our future prospects."*

The weather clearing up, Dr. Richardson went out in search of tripe de roche, leaving Mr. Hood in bed and Hepburn cutting willows for a fire; but the rocks were covered with ice and snow, and he was unsuccessful. On his return he found Michel the Iroquois, who delivered the note from Franklin.t All were surprised to see him alone; but he stated that Belanger had separated from him, and, as he supposed, lost his way, he himself having wandered far from the straight road. They had afterward good reason to suspect the truth of this story, but believed it at that moment, and were rejoiced to see him produce a hare and a partridge,_an unlooked-for supply, which they received with humble thankfulness to the Giver of all good. Franklin's note advised them to advance to a little wood of pines, which would afford better fuel; and to this they removed under the guidance of Michel, who led them straight to the spot.

As he had declared himself so little acquainted with the country as to lose his way, it seemed strange that he should at once conduct them to the thicket. This roused their attention, and made them feel rather uneasy as to his honesty; and various circumstances occurred to increase their suspicions. He requested the loan of a hatchet, when any other hunter would have taken only his knife. He remained abroad all day without any definite employment. He brought them some raw meat, saying it was part of the carcass of a wolf; but which they had afterward reason to believe was a portion of the bodies of Belanger and Perrault, whom they suspected him to have murdered. $\mathrm{He}$

* Franklin's Journey, p. $449 . \quad \dagger$ Ibid. p. 449. 
shunned the society of Dr. Richardson and Mr. Hood, refusing to sleep in the tent, and preferring to lie alone at the fire. On going out with the purpose of remaining a whole day, he often returned abruptly, and when questioned gave vague answers. In a few days he began to regret that he had left Captain Franklin's party, refused to take any share in the labour of cutting wood, talked in a surly and insolent manner, and could scarcely be prevailed upon to go out and hunt at all. These symptoms of gloomy dissatisfaction increased; he resisted all entreaties, and when Mr. Hood, who was now reduced by famine to the last extremity, remonstrated with him, he flew into a violent passion, and exclaimed, "It is of no use hunting; there are no animals ; you had better kill and eat me." He afterward, however, consented to go out, but returned upon some frivolous pretence; and on the succeeding day that dreadful catastrophe took place which will be best given in the words of Dr. Richardson's Journal.

"In the morning," says he, "being Sunday, October 20th, we again urged Michel to go a-hunting, that he might, if possible, leave us some provision, to-morrow being the day appointed for his quitting us; but he showed great unwillingness to go out, and lingered about the fire under the pretence of cleaning his gun. After we had read the morning service, I went about noon to gather some tripe de roche, leaving Mr. Hood sitting before the tent at the fireside arguing with Michel. Hepburn was employed cutting down a tree at a small distance from the tent, being desirous of accumulating a quantity of firewood. A short time after I went out I heard the report of a gun, and about ten minutes afterward Hepburn called to me in a voice of great alarm to come directly. When I arrived I found poor Hood lying lifeless at the fireside, a ball having apparently entered his forehead. I was at first horror-struck with the idea that in a fit of despondency he had hurried himself into the presence of his Almighty Judge by an act of his own hand; but the conduct of Michel soon gave rise to other thoughts, and excited suspicions which were confirmed, when, upon examining the body, I found that the shot had entered the back part of the head and had passed out at the forehead, while the muzzle of the gun had been applied so close as to set fire to the nighteap behind. The 
gun, which was of the longest kind supplied to the Indians, could not have been placed in the position to inflict such a wound except by a second persoll. Upon inquiring of Michel how it hippened, he replied that Mr. Hood had sent him into the tent for the short gun, and that during his absence the long gun had gone off, he did not know whether by accident or not. He held the short gun in his hand at the time he was speaking. Hepburn afterward asserted, that previous to the report of the gun, Mr. Hood and Michel were speaking to each other in an elevated angry tone: he added, that Mr. Hood, being seated at the fireside, was hid from him by intervening willows; but that on hearing the report he looked up, and saw Michel rising up from before the tent-door, or just behínd where Mr. Hood was seated, and then going into the tent. Thinking that the gun had been discharged for the purpose of cleaning it, he did not go to the fire at first; and when Michel called to him that Mr. Hood was dead, a considerable time had elapsed. * * * Bickersteth's Scripture Help was lying open beside the body, as if it had fallen from his hand, and it is probable he was reading it at the instant of his death." *

Such was the melancholy fate of Mr. Hood, a young officer of the highest promise, who by his conduct had endeared himself to every member of the expedition, and whose sufferings, as they were more intense from the peculiarity of his constitution, were borne with a placid and unpretending fortitude which it was impossible to contemplate without emotion. Both Dr. Richardson and Hepburn were convinced he had met his death from the hands of Michel; but to have accused him at that moment would have been the extremity of rashness. They were so reduced by famine that he could easily have overpowered both. His appearance showed that he possessed secret supplies of food; he was of great bodily strength, and was armed to the teeth, carrying, besides his gun, a brace of pistols, an Indian bayonet, and a knife. To have hinted a suspicion, therefore, might have been instantly fatal, and they affected to consider the death of their companion enixrely accidental. As his weakness had been the chief

* Franklin's Journey, vol. iv 12mo. ed. p. 109-112. 
cause of delaying their journey, they now set out for the fort, having first paid the last rites to the dead in the only way which their situation would permit. The ground was so hard and their strength so exhausted, that to dig a grave was impossible; so they carried the body into the willow grove behind the tent, and returning to the fire read the funeral service in addition to their evening devotions.

In the morning, having singed the hair off a portion of Mr. Hood's bufialo robe, they boiled and ate it for breakfast. Meanwhile, the conduct of Michel was so extraordinary, that had they not been already convinced of his guilt, no doubt of it could have remained. Though not a breath of their suspicions reached his ears, he repeatedly protested that he was incenpable of committing such an act; he kept constantly on his guard; appeared fearful of leaving Dr. Richardson and Hepburn alone even for the shortest time : and when Hepburn spoke he listened anxiously, though very imperfectly acquainted with the English language, fixed his eyes keenly upon him, and asked fiercely if he accused him of the murder. He evinced great unwillingness to set out for the fort, and wished Dr. Richardson to proceed to the Coppermine River, where he said the woods would supply plenty of deer. On finding this advice disregarded his conduct became more and more alarming; he muttered to himself, fell into sullen fits of abstraction, and used those convuisive and abrupt gestures often involuntarily exhibited by a person whose mind is full of some dreadful purpose. Suddenly awakening from this revery, he again expressed his unwillingness to return to the fort, and renewed his solicitations to Dr. Richardson to repair to the southern woods, where they would find ample subsistence. On being requested to pursue his own plan alone, and leave them to continue their journey, he broke into an ungovernable fury, accused Hepburn of having told stories anainst him, and assumed such airs of superiority as showed that he knew they were both in his power, at the same time giving vent to expressions of hatred against the white people, calling them deadly enemies, and affirming they had killed and eaten his uncle and two of his relations.

None of these menaces were lost upon Richardson and Hepburn; both felt they were not safe in this man's company; and these dreadful surmises rose into certainty when 
he threw out hints that he would free himself from all restraint on the morrow. Being now convinced that, as he had cruelly murdered Hood, he was resolved also to sacrifice them, they ascribed his not having already done so to the circumstance of his not knowing the way to the fort, and requiring their guidance. They came to this conclusion without any communication with each other; for their fierce companion would not leave them a moment, watching them with a malignant look, and frequently muttering threats against Hepburn. Towards evening, as they approached the spot where it would be necessary to stop for the night, Michel halted to gather tripe de roche, and to their surprise bade them walk on and he would scon overtake them. Hepburn and Dr. Richardson, now left alone together for the first time since Mr. Hood's death, rapidly opened their minds to each other. In addition to the facts already mentioned, others came to light which left not the slightest doubt as to Michel's guilt ; and so convinced was Hepburn of there being no safety for them but in his death, that, though a man of extreme henevolence and deep religious principle, he offered to be the instrument of it himself. "Had my own life," says Dr. Richardson, "alone been threatened, I would not have purchased it by such a measure; but I considered myself as intrusted also with the protection of Hepburn's, a man who by his humane attentions and devotedness had so endeared himself to me that I felt more anxiety for his safety than for my own." Animated by such feelings, and convinced that Michel's death was necessary to self-preservation, he determined that it ought to be by his own and not by Hepburn's hand, and on his coming up shot him through the head with a pistol. It appeared that he had gathered no tripe de roche, and had halted to put his gun in order, no doubt with the intention of attacking them when in the act of encamping.*

Dr. Richardson and Hepburn now pursued their way to the fort; but fatigue, and want of food and fuel, had nearly proved fatal to them. They remarked, however, that repeatedly when death seemed inevitable, an unexpected supply of provisions again restored them; and the confidence that, when no buman help was nigh, they were supported by a

* Eranklin's Journey, p. 457, 458. 
merciful God, inspired them with renewed hope. At last they had the delight of beholding from an eminence the smoke issuing from the chimney of the fort, and immediately after cmbracing those friends for whose fate they had entertained so many melancholy forebodings. So ended this interesting narrative.

The whole party were now once more united, but under circumstances of the most distressing privation; all emaciated to such a degree as to look like living skeletons; their hands shook from weakness, so that to take an aim was impossible; and the rein-deer, partridges, and other game flew or bounded past in joyousness and security, while the unhappy beings who beheld them were gaunt with hunger. The winter was closing in with all its horrors; it became daily more difficult to procure fuel, the labour of cutting and carrying the logs being so grievous that only Dr. Richardson and Hepburn could undertake it; and to scrape the ground for bones, and to cook this miserable meal, was all Captain Franklin could accomplish. On 1st November, the doctor obtained some tripe de roche ; and as Peltier and Samandré were in the last stage of exhaustion, it was hoped a little of the soup might revive them. All was in vain; they tasted a few spoonfuls, but soon complained of a soreness in their throats, and both died in the course of the night, apparently without pain. To inter the bodies, or even carry them to the river, was a task for which the united strength of the survivors was inadequate; all they could do was to remuve them into an opposite part of the house; and the living and the dead remained in awful contiguity under the same roof.

The party was now reduced to four,-Franklin, Richardson, Hepburn, and Adam. The last had become dreadfully low since the death of his companions, and could not bear to be left alone for a moment. Their stock of bones was exhausted, and in a short time it was evident that the severity of the frost must render the gathering of the tripe de roche impossible. Under these circumstances, with death by famine approaching every hour, this little band of pious and biave men were supported by an unwavering reliance on the mercy of God. "We read prayers," says Captain Franklin, "and a portion of the New Testament in the morning and evening, as had been our practice since Dr. Richardson's arrival; and I may remark, that the perform- 
ance of these duties always afforded us the greatest consolation, serving to reanimate our hope in the mercy of the Omnipotent, who alone could save and deliver us." It seemed as if it were the mysterious design of the Almighty to permit them to be reduced to the lowest depth of suffering, that his power might be magnified at the very moment when every human effort appeared uiterly impotent. Hitherto Dr. Richardson and Hepburn had been the healthiest of the party, but they had overwrought themselves, and both sank rapidly. Owing to their loss of flesh, the hardness of the floor, from which they were only protected by a single blanket, rendered the whole surface of their bodies sore; yet the labour of turning from one side to the other was too much for them. As their strength sank, their mental faculties partook of the weakness of their frame; and, to employ the candid and simple expressions of the excellent leader, " an unreasonable pettishmess with each other began to manifest itself, each believing the other weaker in intellect than himself, and more in need of advice and assistance." During this gloomy period, after the first acute pains of hunger (which lasted but for three or four days) had subsided, they generally enjoyed the refreshment of sleep, accompanied by dreams which, for the most part, partook of a pleasant character, and very often related to the pleasures of feasting. $\dagger$

Help, however, was now near at hand, and we shall not impair the affecting description of their deliverance by giving it in any other than Captain Franklin's own words. "On November 7th, Adam had passed a restless night, being' disquieted by gloomy apprehensions of approaching death, which they tried in vain to dispel. He was so low in the morning as scarcely to be able to speak, and Captain Franklin remained by his bedside to cheer him as much as possible, while the doctor and Hepburn went out to cut wood. They had hardly begun their labour when they were amazed at hearing the report of a musket, and could scarcely believe that there was any one near till they heard a shout, and espied three Indians close to the house. Adam and Franklin heard the latter noise, and were fearful that some part of the house had fallen upon one of their cons

* Franklin's Journey, p. 464. † Franklin's Journey, p. 466, 4865, 
panions,-a disaster which had been thought not unlikely. The alarm was only momentary; for Dr. Richardson came in to communicate the joyful intelligence that relief had arrived. He and Captain Franklin immediately addressed their thanksgivings to the Throne of Mercy for this deliverance; but poor Adam was in so low a state that he could scarcely comprehend the information. When the Indians entered he attempted to rise, but immediately sank down again. But for this seasonable interposition of Providence, his existence must have terminated in a few hours, and that of the rest probably in not many days."*

The Indians, who had been despatched by Mr. Back, had travelled with great expedition, and brought a small supply of provisions. They imprudently presented too much food at first; and though aware of the effects which might arise from a surfeit, and warned by Dr. Richardson to eat very sparingly, the sight of the venison was irresistible: and it was devoured by them all, not excluding the doctor himself, with an avidity that soon produced the most acute pains, which during the night deprived them of rest. Adam, whose weakness rendered him unable to feed himself, was not subjected to the same inconvenience, and taking moderate meals revived hourly. All now was thankfulness and cheerful activity. Boudel-kell, the youngest Indian, after an hour's rest, returned to the encampment of Akaitcho, the Dog-rib chief, carrying a note from Captain Franklin, and a request for another supply of provisions. The two others, named in their familiar manner Crooked Foot and the Rat, remained to nurse the white men. Under their care the apartment, lately so desolate, and something between a sepulchre and a lazar-house, assumed a gladdened look which had the best effect. The dead bodies were removed, the room cleaned of its filth and fragments of pounded bones, and large cheerful fires produced a sensation of comfort to which they had long been strangers. The poor sufferers had often cast a wishful eye on a pile of dried wood near the river, but were utterly unable to carry it up the bank. When pointed out to the Indians, they fetched it home witb a rapidity which astonished their feeble friends. "They set about every thing," says Franklin, "with an activity which

* Franklin's Journey, p. 467. 
mazed us. Indeed, contrasted with our emaciated figures and extreme debility, their frames appeared to us gigantic, and their strength supernatural."

Under the care of the Indians, and the blessing of wholesome and regular meals, the strength of the party was so far restored, that, although still feeb!e, on the 16 th, after having united in prayer and thanksgiving to God for their deliverince, they left Fort Fnterprise,-a spot where, as they had formerly enjoyed much comfort, if not happiness, they had latterly experienced a degree of misery scarcely to be paralleled.* The Indians treated them with unremitting kindness, gave them their own snow-shoes, and walked at their side to be ready to lift them up when they fell. In this mamner they pushed forward to the abode of Aliaitcho, the Indian chief, who welcomed them with the utmost hospitality. Soon after they received letters from thrir friends at Fort Providence, and the messenger also brought two trains of dogs, a package of spirits and tobaceo for the Indians, and a supply of shirts and clothes for Captain Franklin and his companions. The gratification of changing their linen, which had been uninterruptedly worn ever since their de. parture from the seacoast, is deseribed as conveying an intensity of comfort to which no words cain do justice. From this spot their progress to Fort Providence and thence to Montreal was prosperous and easy ; and thus terminated their long, fatiguing, and disistrous travels in North America, having journeyed by water and liy land, includ ing their navigation of the Polar Sea, 5550 miles.

So disastrous had been the result of his first expedition, and so appalling the suflerings with which it was accompanied, that nothing assuredly can convey a more honourable testimony to the enthusiastic zeal and unshaken perseverance of Captain Franklin, than the statement of the simple fact, that towards the close of $18: 3$, having learned the determination of govermment to make another attempt to effect a northern passage by sea between the Atlantic and Pacific Oceans, he, to use his own words, "ventured to lay before his majesty's government a plan for an expedition overland to the mouth of the Mackenzie Kiver, and thence by sea to the north-western extremity of America, with the combined 
object also of surveying the coasts between the Mackenzic and the Coppermine Rivers."

It was the opinion of this able oflicer, that in the course he now proposed to follow, reverses similar to those which had surrounded his first journey were scarcely to be apprehended; and his views having met the approbation of government, he received directions for the equipment of the expedition, and was nominated its commander. He had the satisfaction also of being once more accompanied by his valued friend Dr. Richardson; who, unappalled by his former dreadful sufferings, again ofiered his services as naturalist and surgeon, and volunteered to undertake the survey of the coast between the Mackenzie and Coppermine Rivers, while Captain Franklin was occupied in an attempt to reach Icy Cape.* Previous to the departure of the ship's a correspondence was opened with the grovernor and directors of the Hudson's Bay Company; who transmitted injunctions to their oflicers in the fur-countries to provide depôts of provisions at the stations pointed out by Franklin.

The building of proper boats for the navigation of the Arctic Sea, as well as the passage of the rapids between York Factory and Mackenzie River, formed the next object of attention. It was evident that the canoes of birch-bark employed by Sir A. Mackenzie, and by Captain Franklin in his first joumey, though excellently adapted for the Ameriean rivers, uniting lightness and facility of repair with speed, were yet, from the tenderness of the bark, little fitted to resist the force of the arctic waves, or the collision of the sharp-pointed masses of ice. Captain Franklin accordingly obtained the Admiralty's permission to hatve three boats constructed, at Woolwich, under his own superintendence. "They were built," says he, "of mahogany, with timbers of ash, both ends exactly alike, and fitted to be steered either with a ship-oar or a rudder. The largest, being twenty-six feet long and five feet four inches broad, was adapted for six rowers, a steersman, and an officer; it was found to be capable of carrying three tons weight in addition to the crew, and could be transported with ease on the shoulders of six men. The other two boats were twenty-four feet in length,

* Franklin's Narrative of' a Second Fixpedition to the Shores of the Polar Sea. Introductory Chapter, p. 10. 
four feet ten inches lroitl, and held a crew of five men, besides a steersman and an oflicer, with an extra weight of two and a half tons. In addition to these, another little vessel was constructed, at Woolwich, which reflected great credit upon its inventor, Lieutenant-colonel Pasley, of the Royal Engineers. Its shape was exactly that of one of the valves of a walnut-shell, and it was framed of well-seasoned planks of ash, fastened together with thongs, and covered with Mackintosh's prepared canvass. It weighed only cighty-five pounds, and when taken to pieces could be made up in five or six parcels, and again put together in less than twenty minutes, although it was nine feet long by four feet four inches in breadth." ${ }^{*}$ Each person on board was provided with two suits of water-proof dresses, prepared by Mr. Mackintosh, of Glasgow ; the guns, which were of the same bore as the fowling-pieces furnished by the Hudson's Bay company to the Indian hunters, had their locks tempered to resist the cold; each being fitted with a broad Indian dagyer similar to a bayonet, which, on being disjoined, could be used as a knife. Ammunition of the best quality, and a store of provisions sufficient for two years, were also supplied.

The expedition sailed from Liverpool on $16 \mathrm{th}$ February, 1825, and after a favourable passage to New-York, proceeded to Albany, travelled through Utica, Rochester, and Geneva, crossed the Niagara and Iake Ontario, coasted the northern shore of Lake Superior, and thence pushed forward through Rainy Lake, the Lake of the Woods, I take Winipeg, Saskatchawan River, and arrived at Cumberland House on the 15th June. From this station, proceeding northward to Isle à la Crosse, and passing through Deep River and Clear and Buffalo Lakes, they overtook their hoats in Methye River on the morning of 29th June. The advanced period of the season rendered it impossible to embark on the Mackenzie before the middle of August, so that it became necessary to postpone the great expedition till the ensuing summer. They accordingly established their winterquarters on the banks, erecting a habitation and store, which they named Fort Franklin. The superintendence of these buildings was committed to Lientenant Back, while Captain

* Franklin's Second Journey, Intro. Chap. p. 15, 18. 
Franklin determined to deseend the river, take a view of the state of the Polar Sea, and returu to winter-quarters before the extreme cold should set in.

In this voyage there occurred nothing worthy of particular notice till the arrival at Whale Island, where, though Mackenzie liad the strongest reasons to conclude that he had reached the sea, he apye:rs not to have been completely satisfied on that point. Probably his doubts arose from the fresh taste of the water. Franklin, however, proceeded beyond Whale Island, and reaclied the shore of the great Arctic Ocean. "Embarking," says he, "at eleven A. M., we continued our course along the shore of Ellice Island, until we found its coast trending southward of east. There we landed, and were rejoiced at the sea-like appearance to the northward. An island was now discovered to the north-east, looking blue from its distance, towards which the boat was immediately directed. The water, which for the last eight miles had been very shallow, became gradually deeper, and of a more green colour, though still fresh, even when we harl entirely lost sight of the eastern land. In the middle of the traverse we were caught by a strong contrary wind, against which our crews cheerfully contended for five hours. Unwilling to return without attaining the object of our search, when the strength of the rowers was nearly exhausted the sails were set douhle-reefed, and our excellent boat mounted over the waves in a most buoyant manner, while an opportune alteration of the wind enabled us in the course of another hour to fetch into smoother water under the shelter of the island. We then pulled across a line of strong ripple, which marked the termination of the fresh water, that on the seaward side being brackish; and in the further progress of three miles to the island, we had the indescribable pleasure of finding the water decidedly salt. The sun was setting as the boat touched the beach; we hastened to the most elevated part of the island, about two hundred and fifty feet high, to look around; and never was a prospect more gratifying than that which lay open to us. The Rocky Mountains were seen from S. WW to $W .12 N$., and from the latter point, round by the north, the sea appeared in all its majesty, entirely free from ice, and withont any visible obstruction to its navigation. Many seals and black and white whales were seen sportingr on its waves, and the 
whole scene was calculated to excite in our minds the most flattering expectations of our own success and that of our friends in the Hecla and the Fury." Franklin pronounces a high enconium on the accuracy of Mackenzie, and considers him as completely entitled to the praise of having reached the Arctic Sea, although, owing to the frail construction of the Indian canoes, it was impossible for him to sail to the point where the water became salt.

Having accomplished his design in this preliminary journey, Franklin returned on 5th September to his winterquarters on Great Bear Lake. About the same time Dr. Kichardson arrived from his excursion to the north-eastern shores of the same extensive sheet of water, having completed his survey as far as the influx of Dease's River, and ascertained that the first rapid was the best point to which the eastern detachment of the expedition should direct its course on their return from the Coppermine in the following season. Meantime the people were so busily employed that time never hung heavy on their hands, and the shortest day came almost unexpectedly upon them. The Canadians and Indians were engaged in fishing and hunting for the support of the whole party, and during the autumn the nets yielded daily eight hundred fish of the kind called herringsahmon. Four Dog-rib Indians, along with the two interpreters, Augustus and Ooligbuck, were employed in hunting rein. deer, and the sailors were divided into different parties, to whom separate duties were allotted; such as attending on the nets, bringing home the venison killed by the hunters, felling, carrying, and splitting wood, and exercising themselves in running as letter-carriers on snow-shoes between Fort Franklin and two other small posts established on the Mackenzie and Slave Lake. A school also was opened, in which, during the long winter evenings, the officers instructed the sailors in reading, writing, and arithmetic; and during the hours of relaxation the hall was given up to the men to divert themselves with any game they chose ; on which occasions they were always joined by the officers. Sunday was invariably a day of rest, and the whole party attended divine service morning and evening. Besides this, the offcers had ample employment in noting down the thermo-

* Franklin's Second Journey, p. 34-36. 
metrical, magnetical, and atmospherical observations, in writ. ing their journals, finishing their charts and drawings, and arranging the objects of natural history which had been collected.* They were amused by occasional visits of the Dog-rib Indians and various other tribes; and Christmasday falling on a Sunday, they on the succeding evening gave a dance and supper, which was attended by sixty persons including savages. "Seldom," says Franklin, "in such a confined space as our hall, or among the sanse number of persons, was there a greater variety of character or greater confusion of tongues. The party consisted of Englishmen, Highlanders (who mostly conversed with each other in Gaelic), Canadians (who spoke French), Esquimaux, Chipewyans, Dog-ribs, Hare Indians, Cree women and children, all mingled together in perfect harmony, while the amusements were varied by English, Gaelic, and French songs." $\dagger$

The spring now appronched, and the migratory animals, which observe with beautiful exactness their periods of departure and arrival, began to appear, gladdening the yet wintry face of nature. On 5th October the last swan had passed to the southward, and on the 11th the last brown duck was noticed. On 6th May the first swan was seen, and on the 8 th the brown ducks reappeared on the lake. The mosses began to sprout, and various singing birds and orioles, along with some swifts and white geese, arrived soon after. It is remarked by Dr. Richardson, that the singing birds, which were silent on the banks of the Bear Lake during the day, serenaded their mates at midnight; at which time, however, it was quite light. On 20th May the little stream which flowed past the fort burst its icy chains, and the laughing geese arrived to give renewed cheerfulness to the lake. Soon after this the winter-green began to push forth its flowers; and under the increasing warmth of the sun's rays the whole face of nature underwent a delightful change. The snow gradually melted, the ice broke up from the shores of the lake, the northern sky became red and leminous at midnight, the dwarf-birch and willows axpanded their leaves, and by the $3 \mathrm{~d}$ June the anemones,

* Franklin's Second Journey, p. 54-56.

† ibid. p. 67 
the tussilago, the I:aplanil rose, and other early plants, were in full flower.*

Admonished by these pleasing changes, Captain Franklin prepared to set out, and on 15th. Jume the equipments for the bats were completed. Fourteen men, including Augustus the Esquimatx interpreter, accompanied the commander-in-chief and Lieutenant Back in: the two larger boats, the Lion and the Reliance; while nine men, and Ooligbuck another interpreter, attended Dr. Richardson and Mr. Kendall in the Dolphin and the Union. Spare blankets, and all that could be useful for the voyage, or as presents to the Esquimaux, were divided between the eastern and western parties. On the Sunday before their departure, the officers and men assembled at divine worship, and, in addition to the usual service, the special protection of the Almighty was implored for the enterprise upon which they were about to be engaged. All was now ready, and on Tuesday, 28th June, they embarked upon the Mackenzie, with the navigation of which the reader is already familiar. On the 4th July they reached that part where the river divides into various channels, and the two parties had determined to pursue different directions. The expedition which was to follow the western branch, commanded by Captain Franklin, embarked first at Dr. Richardson's desire, with a salute of three hearty cheers from their companions, and as they dropped down the river and passed round a point of land they perceived their friends who were to follow the eastern branch employed in the bustle of embarkation. All were in high spirits, and it was impossible not to contrast their present complete state of equipment with the circumstances of their first disastrous journey.

On reaching the mouth of the Mackenzie, the western expedition came almost immediately into contact with the Esquimaux. Captain Franklin observed an encampment upon a neighbouring island, and instantly proceeded to open a communication. A selection of presents was made, and at the same time every man was directed to have his gun ready for use. Having adopted these precautions, they steered direct for the island with their ensigns flying. The boats touched ground when about a mile from the beach. Signs 
were maile to the Esquimaux to come off, and the English pulled back a little to await their arrival in deeper water. Three canoes, each carrying only a single person, pushed off, and these were followed rapidly by others; so that in a few minutes the whole space between the boats and the shore was alive with those little vessels, which they name kayaks. An attempt was at first made to count them, and the sailors got the length of seventy; but they increased in such quick succession as to baffle their further efforts.

At first every thing proceeded in a friendly manner. Augustus, after delivering a present, informed them, that if the English succeeded in finding a navigable chamnel for large ships, an advantageous trade would be opened. This intimation was received with a deafening shout, and the sight of the presents which had been carried away by the three foremost kayaks inflamed the cupidity of their cornpanions ; so that the boats were in a moment surrounded by nearly three hundred persons, offering for sale their bows, arrows, and spears, with a violence and perseverance which became at last exceedirgly troublesome, and Captain Franklin directed the boats to be put to seaward. At this moment a kayak was upset by one of the oars of the Lion, and its unhappy possessor was struck by the accident with his head in the mud and his heels in the air. He was instantly extricated, wrapped in a warm great-coat, and placed in the boat, where, although at first excessively frightened and angry, he soon became reconciled to his situation, and looking about, discovered many bales and other articles which had hitherto been carefully concealed. His first impulse was to ask for every thing he saw, his next to be indignant that his requests were not granted; and on joining his companions, as they afterward learned, he harangued on the inexhaustible riches of the Lion, and proposed a plan for a general attack and pillage of both the boats. This scheme was immediately carried into execution; and although the plunderers at first affected to be partly in sport, matters soon assumed a serious complexion. Two of the most powerful men, leaping on board, seized Captain Franklin, forced him to sit between them, and when he shook them off, a third took his station in front to catch his arm whenever he attempted to raise his gun or lay his hand on the broad dagger which hung by his side. During this assault the two boats 
were violently aragged to the shore, and a numerous party, stripping to the waist and brandishing their long sharp, knives, ran to the Reliance, and commenced a regular pillage, handing the articles to the women, who, ranged in a row behind, quickly conveyed them out of sight. No sooner was the bow cleared of one set of marauders than another party commenced their operations at the stern. 'The Lion was beset by smaller numbers, and her erew, by firmly keeping their seats on the canvass cover spread over the cargo, and beating off the natives with the butt-end of their muskets, succeeded in preventing any article of importance from being carried away. Irritated, at length, by their frequent failure, the Esquimaux made a simultaneous charge, and, leaping on board, began to wrest the daggers and shot-belts from the sailors, and to strike with their knives. In the midst of this attack, when the crew in the Lion were nearly overpowered and their commander disarmed, all at once the natives took to their heels, and concealed themselves behind the drift-timber and canoes on the beach. This sudden panic was occasioned by Captain Back, whose boat at this time had been got afloat, commanding his crew to level their muskets, - a proceeding which was immediately observed by the Esquimaux, though not noticed by Captain Franklin's men, who were wholly occupied in defending themselves. The Lion happily floated soon after; and as both boats pulled off, Captain Franklin desired Augustus to inform some of the Esquimaux, who manifested a disposition to follow and renew the attack, that he would shoot the first man who ventured to approach within musket-range.*

In the evening, Augustus anxiously entreated permission to attend a conference of his countrymen on the shore, to which he had been formally invited. The courage and fidelity of this person had much endeared him to the English, and it was not without hesitation that Captain Franklin agreed to his request, as he stated his determination to reprove the natives for their disgraceful conduct. He was at length allowed to go, and by the time he reached the shore the number of Esquimaux amounted to forty, all of them armed. On landing, he walked undauntedly into the middle of the assembly, and addressed them in the following 
animated speech, which he afterward repeated to his Eng lish friends:- "Your conduct," said he, "has been very bad, and unlike all other Esquimaux. Some of you even stole from me, your countryman-but that I do not mind. I only regret that you should have treated in this violent manner the white people, who came solely to do you kindness. My tribe were in the same unhappy state in which you now are before the white people came to Churchill; but at present they are supplied with every thing they need ; and you see that I am well clothed, I get every thing I want, and am very comfortable. You cannot expect, after the transactions of this day, that these people will ever bring any articles to your country again, unless you show your contrition by returning the stolen goods. The white people love the Esquimaux, and wish to show them the same kindness that they bestow upon the Indians. Do not deceive yourselves, and suppose that they are afraid of you; I tell you they are not, and that it is entirely owing to their humanity that many of you were not killed to-day, for they have all guns with which they can destroy you either near or at a distance. I also have a gun, and can assure you that if a white man had fallen, I would have been the first to have revenged his death." During this speech, which was delivered, as they perceived from the boats, with much energy and spirited gesticulation, the Esquimaux expressed their approbation by frequent shouts, and on its conclusion inade a very penitent, though somewhat singular apology : "They had never seen white men before," they said, "and really all the things in the boats were so beautiful and desirable that it was impossible not to steal them. As they were very anxious, however, for the friendship and trade of the white men, they solemnly promised never to repeat such conduct, and, at the request of Augustus, sent back the large kettle, the tent, and some pairs of shoes which they land carried off."* 'T'he interpreter was afterward invited to a dance, and a friendly understanding seemed to be established; but Captain Franklin soon discovered that the professions of the natives were hollow and treacherous; and zothing but his jealous precautions saved him and his com-

* Franklin's Second Journey, p. 108, 109. 
panions from massacre, in which it had been resolved to include the faithful Augustus.

Their voyage along the coast in the direction of westnorth-west, after a progress of twelve miles, was impeded by the ice stretching from the shore far to seaward. The boats were in consequence hauled up; and as the frozen masses were piled round to the height of thirty feet, it became necessary to await the breaking up of this formidable barrier. Having gone to sleep, the officers were startled at midnight by the guard calling to arms : three Esquima:ıx, belonging to a large party encamped at some distance, had stolen forward, and been only discovered when close at hind. Alarmed at the appearance of the men, who stood to their arms, the strangers were on the point of discharging their arrows, when they were arrested by the loud voice of $\mathrm{Au}$ gustus, who explained the object of the expedition, and dilated upon the advantages which they would derive from it. A present confirmed his statement, and an amicable intercourse was opened,- - line, however, being first drawn at a certain distance from the tents, across which no Esquimaux was to pass under the penalty of being instantly shot. Against this they made no remonstrance, only remarking, when informed of the treacherous conduct of the natives at the mouth of Mackenzie River, that "these were bad men, altogether different from them, and never failed either to steal or quarrel whenever an opportunity was offered." The delight exhibited by these people, including the most elderly among them, on receiving any little present, was exactly similar to that of children when they get hold of toys. They ran from one thing to another; examined with restless curiosity every part of Augustus's dress, who, to gratify his vanity, had put on his gayest apparel ; and, ignorant of the uses of the articles presented to them, they walked about with cod-fish hooks and awls dangling from the nose, and copper thimbles strung to their trousers or rein-deer jackets. The men were robust, and taller than those seen on the east coast by Captain Parry, though their'manner of life appeared to be nearly the same. With the broad nose and small eyes, which peculiarly distinguish the whole Esquimaux tribes, they had the cheek-bones less projecting than those of the eastern coast. From a constant exposure to the glare of the ice and snow, the whole party were 


\section{$1 ! 2$}

DRESS AND MANNERS OF THE ESQUMAUX.

atilicted with sore eyes, and two of the old men seemet nearly blind. 'They wore the hair on the upper lip and chin, and every man had pieces of bone or shells thrust through the septum of the nose, while holes were piercest

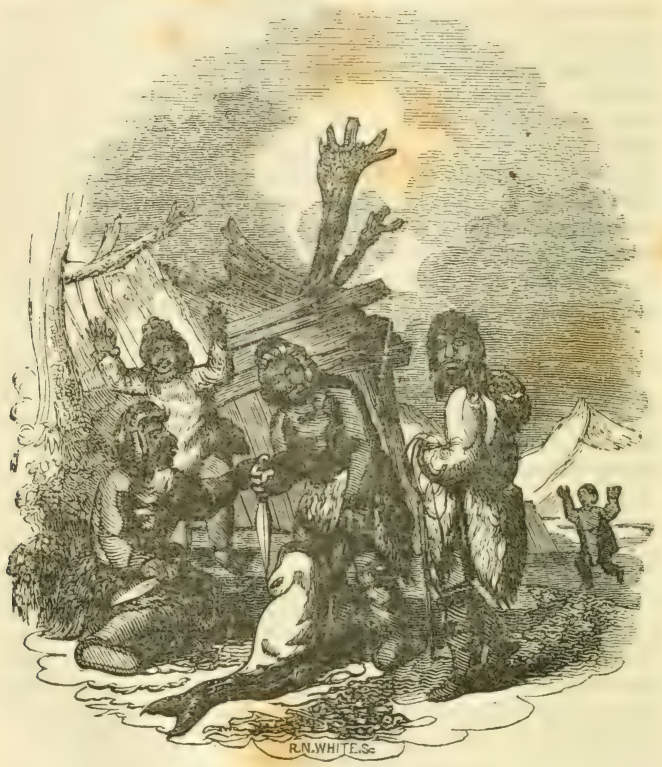

un each side of the under lip, in which were placed circular pieces of ivory with a large blue bead in the centre,-ornaments which they valued highly, and declined selling. Their clothes consisted of a jacket of rein-deer skin, wum a skirt behind and before, and a small hood; breeches of the same material, and large seal-skin boots. 'The dress of the females diflered from that of the men only in their wearing 
wide trousers, and in the size of their hoods, which did not fit close to the head, but were made large for the purpose of receiving their children : these were ornamented with stripes of different coloured skins, and round the top was fastened a band of wolf's hair, made to stand erect. The women were from four feet and a half to four feet threequarters high, and some of the younger, though too corpulent, were pretty; their black hair was tastefully turned up from behind to the top of the head, and braided with strings of white and blue beads and cords of white deerskin. Both men and women were much pleased by having their portraits sketched by Captain Back; and one young lady, who sat for a full-length and chose the extraordinary attitude of stuffing both hands into her breeches-pockets, interrupted the labours of the draughtsman by repeatedly jumping into the air, and smiling in a very ludicrous and irresistible manner. The men were armed with bows and arrows, long knives, which they concealed in the shirtsleeve, and spears tipped with bone.*

The Esquimaux had predicted, that as soon as a strong wind began to blow from the land it would loosen the ice; and on 12th July a heavy rain with a pretty high gale set in, and opened up a passage. The boats accordingly were launched; and, passing a wide bay named by the commander after his friends Captains Sabine and Kay, they were suddenly arrested by a compact body of ice, and enveloped at the same time in a dense fog. On attempting to pull back for the purpose of landing, they discovered that the ice had closed between them and the shore. In this situation only one alternative was left, which was to pull to seaward and trace the outer border of the ice. This they at last effected; though a sudden change of wind brought on a heavy swell, and surrounded them with floating masses of ice, which threatened to crush the boats to pieces. They succeeded, however, after five hours employed in pulling in and out between these floating icebergs, in reaching the shore and landing a little to the west of Point Sabine. After a detention of txu days they proceeded as far as Point Kay; but being here again impeded by a compact body of ice, which extended to seaward as far as the eye could

* Franklin's Second Journey, p. 118, 119. 
reach, they were obliged to encamp and wait patiently for the first strong breeze from the land.

The time of their sojourn in these arctic solitudes was pleasantly occupied in making astronomical observations, collecting specimens of the plants in flower, sketching scenery, and completing charts of the coast. Augustus went in search of his countrymen, and returned at night with a young Esquimaux and his wife, who, after a few presents, became loquacious, and informed them that the ice would soon break up. Symptoms of this desirable chango were accordingly observed next day, and with great labour they reached Herschel Island. At the moment they made the shore a herd of rein-deer came bounding down to the beach, pursued by three Esquimaux hunters, and immediately took the water, while the natives, startled at sight of the strangers, gazed for a moment, consulted among themselves, changed the heads of their arrows, and prepared their bows. Their hostile intentions, however, were laid aside when they were addressed by Augustus; and in the evening a large party arrived, bringing dried meat, fish, and game, for which they received presents in exchange, which set them singing and dancing round the encampment for the greater part of the night.

From these people was collected some curious information. They stated that they procured beads, knives, and iron principally from Esquimaux residing far away to the west, and also from Indians who came annually from the interior by a river directly opposite the encampment, to which Captain Franklin gave the name of Mountain Indian River.* Whence the Indians or the Esquimaux obtained these goods they could not tell, but supposed it was from Kabloonacht or white men, at a great distance to the west. The articles were not of British manufacture, from which Captain Franklin concluded that the Kabloonacht must be the Russian fur-traders.

It was with great difficulty that the boats made even a short distance from Herschel Island. The ice repeatedly closed in upon them, leaving only a narrow channel, often too shallow to float the boats, and dense fogs now became frequent, rendering their navigation peculiarly hazardous.

* Franklin's Second Journey, p. 130, 131. 
These dreary curtains hanging over the ice gave it the appearance of water, and exposed them to the danger of being shut in by an impenetrable barrier when they expected an open sea. They continued their course, however, till they came abreast of Mount Conybeare, when they encamped, and crossing a swampy level ascended to the summit, from which they enjoyed a striking view into the interior. Three noble ranges of mountains were seen parallel to the Buckland chain, but of less altitude, while the prospect was bounded by a fourth range, mingling their pyramidal summits with the clouds, and covered with snow. From this last encampment their advance was extremely slow. The boats were pushed forward through small lanes, the utmost vigilance being necessary to prevent their being entirely shut in, as a few hours often made essential changes, and their frail craft could only be saved by being frequently hauled upon the beach. The calm weather also retarded them, and they earnestly longed for a strong gale to break up the compacted fields of ice, and permit them to continue their voyage.

After a detention of some days their wishes seemed about to be gratified; at midnight, on the 25th July, a strong south-westerly breeze sprang up, accompanied by thunder and lightning; but in the morning an impenetrable fog hung over the sea. On the land side the prospect was equally dreary; an extensive swamp, in which they sank ankle-deep at every step, prevented any excursions into the intericr, and the clouds of mosquitoes which for ever buzzed around them kept them in a perpetual irritation. At length, however, the fog dispersed, disclosing an open lane of water about half a mile from shore; following its course for eight miles they came to the mouth of a wide river, which had its rise in the British range of mountains. Its course approached near the line of demarcation between the American dominions of Great Britain and Russia, and Captain Franklin named it the Clarence River, after his present majesty, then lord high admiral. On the most elevated part of the coast near its mouth they erected a pile of driftwood, under which was deposited a tin box, containing a royal silver medal, and an account of the proceedings of the expedition; after which the union flag was hoisted with three hearty cheers. 
They now continued their voyage, though often beset by ıce and interrupted by fogs, and passing the boundary between Russian and British America descried an encampment of natives on a low island, surrounded by many oomiaks and kayaks guarded by Esquimaux dogs, while their masters were fast asleep in the tents. The interpreter being despatched to arouse them, a singular scene took place. At his first call a little squabby woman rushed out in a state of perfect nudity, uttered a loud yell, and instantly ran back again to rouse her husband, who, shouting out that strangers were at hand, awoke the whole band. In a moment all seized their arms, and without waiting to put on their deerskin breeches or jackets, swarmed out upon the beach, which in an instant was covered with fifty-four grown-up persons completely naked, very outrageous, dirty, and ugly. A short parley quieted their fears, an interchange of presents took place, and the boats crossed Camden Bay, having in view the noble range of the Romanzoff Mountains, whose peaks were covered with snow.

Soon after they arrived at the mouth of a river, which discharged into the sea so great a volume of water that even three miles from land the taste was perfectly fresh; and having reached latitude $70^{\circ} 7^{\prime}$, farther progress was prevented by ice closely packed on the outer border of a reef, and they discovered that the great chain of the Rocky Mountains either terminated abreast of their present situation, or receded so far to the southward as to fade away is the distance. During their detention Captain Back, to whose pencil we are indebted for many admirable drawings of arctic scenery, made a sketch of the most western mountain, which they named Mount Copleston.* Various circumstances now warned them that much further progress along this inhospitable coast was impracticable. The fogs became more frequent and perilous, the water was often so shallow that even at two miles from shore the boats grounded, and on getting into deeper soundings, the repeated shocks received from masses of floating ice severely injured their timbers, especially those of the Lion, which was very leaky. Still they struggled on from Flaxman

* Franklin's Second Journey, p. 150. See the Vignette to this volume. 
Is and along a low, desolate shore, rendered more dreary by the stormy weather, till on the 10th a gale brought along with it a thick fog, and they hauled up the boats, encamping on a low spot, which they named Foggy Island. Here they kindled fires, dried their clothes, which were completely wet with the moisture of the atmosphere, and amused themselves in their murky prison by proceeding in search of rein-deer. The fog caused frequent and sometimes ludicrous mistakes; and on one occasion, after the men had spent a long time in stealing upon some deer, and were congratulating themselves on coming within shot, to their amazement the animals took wing and disappeared in the fog, with a scream and cackle which at once declared their genus, and seemed to deride the credulity of their pursuers. "We witnessed with regret," says Captain Franklin, " in these short rambles, the havoc which this dreary weather made among the flowers. Many which had been blooming upon our arrival were now lying prostrate and withered, and these symptoms of decay could not fail painfully to remind us that the term of our operations was fast approaching. Often at this time did every one express a wish that we had some decked vessel, in which the provisions could be secured from the injury of salt-water, and the crew sheltered when they required rest, that we might quit this shallow coast and steer at once towards Icy Cape."* So frequently did they attempt to fulfil this desire, and so perpetually were they driven back by the fog closing in upon them, that the sailors declared the island was enchanted. Indeed, to a superstitious mind the appearances furnished some ground for believing it. The fog would often disperse, and permit a short glimpse of a point about three miles distant, bearing north-west-by-west; in a momen every hand was at work, the boats were launched, the crews embarked; but before they could be dragged into deep water the spirit of the mist once more drew his impenetrable curtain round them, and after resting a while on their oars, they were compelled to pull back to their old quarters. Scarcely had they kindled a fire and begun to dry their clothes, soaked with wading over the flats, when the fog again opened, the boats were launched, and the desire

- Franklin's Second Journey, p. 154. $\mathrm{R} 2$ 
point almost gained; but their tormentor once more enveloped earth and ocean in a thicker gloom than before. "Fog is, of all others," says Captain Franklin, "the most hazardous state of the atmosphere for navigation in an icy sea, especially where it is accompanied by strong breezes; but particularly so for boats where the shore is unapproachable. If caught by a gale, a heavy swell, or drifting ice, the result must be their wreck, or the throwing their provisions overboard, to lighten them so as to proceed in shoalwater. Many large pieces of ice were seen on the border of the shallow water, and from the lowness of the temperature we concluded that the main body was at no great distance."*

The nights were now lengthening: the grasses and the whole aspect of the vegetation was autumnal; their stores of drift-wood had been so much drawn upon, that though the tents were wet through, and they were for warmth obliged to wrap their feet in blankets, no fire was allowed except to cook the victuals. The provisions were barely sufficient for the support of the party on their return, while the frequency of the fogs, the shallowness which prevented the boats from floating, the heavy swell that, as the wind freshened, rose upon the flats, compelled them to haul farther from land, and the danger which in doing so they necessarily incurred from the drift-ice,-formed an accumulation of difficulties which rendered their progress from Point Anxiety across Prudhoe Bay to Return Reef the most discouraging and painful part of the whole voyage. It was now the 16th of August, and the boats, though the exertions of the crews had been unwearied, were only half-way between the mouth of Mackenzie River and Icy Cape. The young ice had already begun to form at night on the pools of fresh water, and the mind of the commander recurred naturally and wisely to his former experience. He recollected that only one day later, and in a latitude two degrees more southerly, he had in his first voyage encountered severe storms of wind and snow, and that in another fortnight the winter would set in with all its horrors. Already the sun began to sink below the horizon, and with this change the mean temperature of the atmosphere rapidly decreased; the deer were hastening from the coast; the

- Franklin's Second Journey, p. 156. 
Esquimaux had ceased to appear; no winter houses gave indications that this remote coast was inhabited; and the autumnal parties of geese hourly winging their flight to the westward, indicated that winter had already surprised them in their polar solitudes. It had been Franklin's great object to double Icy Cape, and meet the expedition under Captain Beechey in Kotzebue's Inlet; but from the distance and the advanced season this was now impracticable. On the other hand, his instructions directed him, " if, in consequence of slow progress, or other unforeseen accident, it should remain doubtful whether the expedition should be able to reach Kotzebue's Inlet the same season, to commence their return on the 15th or 20th of August." To relinquish the great object of his ambition; and to disappoint the confidence reposed in his exertions, was a sacrifice which cost him no ordinary pain; and had he been then aware of the fact (with which the reader will be immediately acquainted) that the barge of the Blossom was at that moment only 146 miles distant, we have his own authority for stating that no difficulties or dangers would have prevailed on him to return; but, under the circumstances in which he was placed, to make any further effort in advance was incompatible with the higher duties which he owed to his officers and crew. After a mature consideration of every thing, he formed the reluctant conclusion that they had reached the point where persevcrance would have been rashness, and their best efforts must have only led to a more calamitous failure.* It was resolved therefore to return; and on the morning of the 18th of August they began their retreat to the Mackenzie River, which, without any material danger, with the exception of a severe gale encountered off Point Kay, they regained on the 4 th of September. Thence they proceeded to Fort Franklin, where they met Dr. Richardson, Mr. Kendall, and their friends of the eastern expedition, who, after a prosperous and interesting voyage to the mouth of the Coppermine, had returned to the Fort on the 1st September.

Of this interesting journey our limits will only permit a very cursory glance. Fortunately for the eastern expedition, the coast between the mouths of the Mackenzie and the Coppermine Rivers presented none of those serious

* Franklin's Second Journey, p. 161, 162, 165. 
obstacles which at every step were starting up in the dreary and protracted route of the western party ; and they consequently accomplished a voyage of about 500 miles, between the 4th of July and 8th of August. It was eminently successful in the accurate survey of this hitherto unexplored coast, but unvaried by any remarkable incidents. The Esquimaux on various parts of the coast were more numerous, pacific, comfortable, and wealthy than the western tribes; but their civilization had not eradicated the propensities for thieving. On one occasion the boats were surrounded by a fleet of about fifty kayaks, and an attack was made exactly similar to that upon Franklin; but though the object was the same it was pursued with less vigour, and the moment the sailors levelled their muskets the whole party dispersed with precipitation.

On arriving at Atkinson Island they discovered, under shelter of a chain of sand-hills drifted by the wind to the height of thirty-feet, a small Esquimaux town, consisting of seventeen winter houses, besides a larger building, which Dr. Richardson at first conjectured to be a house of assembly for the tribe. Ooligbuck the interpreter, however, whose ideas were more gross and commonplace, pronounced it to be a general eating-room. "This large building," says Dr. Richardson, "was in the interior a square of twenty-seven feet, having the log roof supported on two strong ridge-poles two feet apart, and resting on four upright posts. The floor in the centre formed of split logs, dressed and laid with great care, was surrounded by a raised border about three feet wide, which was no doubt meant for seats. The walls three feet high, were inclined outwards, for the convenience of leaning the back against them, and the ascent to the door, which was on the south side, was formed of logs. The outside, which was covered with earth, had nearly a hemispherical form, and round its base were ranged the sculls of twenty-one whales. There was a square hole in the roof, and the central log of the floor had a basin-shaped cavity one foot in diameter, which was perhaps intended for a lamp. The general attention to comfort in the construction of the village, and the erection of a building of such magnitude, requiring a union of purpose in a considerable number of people, were evidences of a more advanced progress towards civilization than had yet been found among the 
Esquimaux. Whale-sculls were confined to the large building, and to one of the dwelling-houses, which had three or four placed round it. Many wooden trays and hand-barrows for carrying whale-blubber were lying on the ground, most of them in a state of decay."*

On making the traverse of Harrowby Bay, land was seen round the bottom; and on nearing shore twelve tents were distinguished on an adjoining eminence. When the boats appeared, a woman who was walking along the beach, gave the alarm, and the men rushed out, brandishing their knives, and employing the most furious expressions. In vain Ooligbuck endeavoured to calm their apprehensions, explaining that the strangers were friends; they only replied by shouts, leaps, or hideous grimaces, intended to inspire terror, and displayed great agility, frequently standing on one foot and throwing the other nearly as high as their head. Dr. Richardson, nothing intimidated by these gesticulations, bethought himself of enouncing, at the highest key he could reach, the word "Noowœrlawgo," meaning, "I wish to barter," and the sound operated like a spell. The savages instantly became quiet; one of them ran to his kayak, paddled off to the boats, and was followed by crowds, who fearlessly came alongside, readily exchanging bows, arrows, spears, and dressed seal-skins, for bits of old iron-hoop, files, and beads. "The females," says Richardson, "unlike those of the Indian tribes, had much handsomer features than the men; and one young woman of the party would have been deemed pretty even in Europe. Our presents seemed to render them perfectly happy, and they danced with such ecstasy in their slender boats as to incur more than once great hazard of being overset. A bundle of strings of beads being thrown into an oomiak, it was caught by an old woman, who hugged the treasure to her breast with the strongest expression of rapture; while another elderly dame, who had stretched out her arms in vain, became the very picture of despair. On its being explained, however, that the present was intended for the whole party, an amicable division took place; and to show their gratitude, they sang a song to a pleasing air, keeping time with their oars. They gave us many pressing invitations to pass the night at their

* Franklin's Second Journey, p. 217 
tents, in which they were joined by the men; and to excite our liberality the mothers drew their children out of their wide boots, where they are accustomed to carry them naked, and holding them up, begged beads for them. For a time their entreaties were successful; but being desirous of getting clear of our visiters before breakfast-time, we at length told them the stock was exhausted, and they took leave."*

The voyage, owing to the clear atmosphere, the unencumbered state of the coast, and the abundant supply of provisions, was pursued with ease and comfort; and on 8th August having made a bold cape, rising precipitously from the sea to the height of 350 feet, Dr. Kichardson and Mr. Kendall climbed the promontory, and descried in the distance the gap in the hills at Bloody Fall, through which the Coppermine holds its course. Delighted with the prospect of so near a termination of their labours, they communicated the intelligence to the crew, who received it with expressions of profound gratitude to the Divine Being for his protection during the voyage. On reaching the river the men were in excellent condition, fresh and vigorous for the march across the barren grounds on their return to Fort Franklin, which, as already mentioned, they reached in safety on the 1st of September. On approaching within a few days' journey of the fort, a pleasant adventure occurred, characteristic of Indian gratitude and friendship. The party had supped, and most of the men were retired to rest, when Mr. Kendall, in sweeping the horizon with his telescope, descried three Indians coming down a hill towards the encampment. More moss was thrown on the fire, and the St. George's ensign hoisted on the end of a musket, to show the comers that they were approaching friends; but they hid the youngest of their number in a ravine, and approached slowly and with suspicion. Mr. Kendall and Dr. Richardson immediately went unarmed to meet them, and as they came up one held his bow and arrows ready in his hand, and the other cocked his gun; but as soon as they recognised the doctor's dress, - the same he had worn the preceding autumn in his voyage round Bear Lake, and which was familiar to most of the Hare Indians,- they shouted in an

* Franklin's Second Journey, p. 226. 
ecstasy of joy, shook hands most cordially, and called loudly for the young lad whom they had hid to come up. "The meeting," says Dr. Richardson, "was highly gratifying to ourselves as well as to the kind natives ; for they seemed to be friends come to rejoice with us on the happy termination of our voyage."**

It had naturally occurred to government, that if the expeditions under Captains Parry and Franklin should be successful, their stores would be exhausted by the time they reached Behring's Strait. It was certain also that Franklin would be destitute of any means of conveyance to Europe ; and to supply these wants government resolved that a vessel should be sent out to await their arrival in Behring's Strait. For this purpose, accordingly, Captain F. W. Beechey sailed in the Blossom from Spithead on the 19th May, 1825. The vessel was a twenty-six gun ship; but on this occasion mounted only sixteen. She was partially strengthened, and adapted to this peculiar service by increasing her stowage. A boat was also supplied to be used as a tender, built as large as the space on deck would allow, schooner-rigged, decked, and fitted up in the most complete manner. Cloth, beads, cutlery, and various other articles of traffic, were put on board, and a variety of antiscorbutics were added to the usual allowance of provision. Aware that he must traverse a large portion of the globe hitherto little explored, and that a considerable period would elapse before his presence was required on the coast of America, Captain Beechey was instructed to survey the parts of the Pacific within his reach, of which it was important to navigators that a more correct delineation should be laid down. These observations were not, however, to retard his arrival at the appointed rendezvous later than the 10 th of July, 1826 ; and he was directed to remain at Behring's Strait to the end of October, or to as late a period as the season would admit, without incurring the risk of spending the winter there. During this interval he was to navigate from Kotzebue's Sound northward, and afterward to continue in an easterly course along the main shore as far as the ice would allow. Captain Beechey's survey of various portions of the Pacific does not fall within the plan of this work.

* Franklin's Second Journey, p. 274. 
On the $2 \mathrm{~d}$ of June, having left the Sandwich Isles, ho shaped his course for Kamtschatka, and on the 27th was becalmed within six miles of Petropalauski. The best guides to this harbour are a range of high mountains, on one of which, uprvards of 11,000 feet in height, a volcano is in constant action. It was a serene and beautiful evening when they approached this remote quarter of the world, and all were struck with the magnificence of the mountains capped with perennial snow, and rising in solemn grandeur one above the other. At intervals the volcano emitted dark columns of smoke; and from a sprinkling of black spots upon the snow to the leeward it was conjectured there had been a recent eruption. From Petropalauski Captain Bee. chey sailed on the 1st of July for Kotzebue's Sound. "We approached," says he, "the strait which separates the twc great continents of Asia and America, on one of those beautiful still nights well known to all who have visited the arctic regions, when the sky is without a cloud, and when the midnight sun, scarcely his own diameter below the horizon, tinges with a bright hue all the northern circle. Our ship: propelled by an increasing breeze, glided rapidly along a smooth sea, startling from her path flocks of aquatic birds, whose flight in the deep silence of the scene could be traced by the ear to a great distance." Having closed in with the American shore some miles northward of Cape Prince of Wales, they were visited by a little Esquimaux squadron belonging to a village situated on a low sandy island. The natives readily sold every thing they possessed, and were cheerful and good-humoured, though exceedingly noisy and energetic. Their bows were more slender than those of the islanders to the southward, but made on the same principle, with drift-pine, assisted with thongs of hide or pieces of whalebone placed at the back, and neatly bound with small cord. The points of their arrows were of bone, flint, or iron, and their spears headed with the same materials. Their dress was similar to that of the other tribes on the coast. It consisted of a shirt, which reached half-way down the thigh, with long sleeves and a hood of rein-deer skin, and edged with gray or white fox-fur. Besides this they had a jacket of eider-drake skins sewed together, which, when engaged in war, they wore below their other dress, reckoning it a tolerably efficient protection against an arrow 
or a spear-thrust. In wet weather they threw over the fur dress a shirt made of the entrails of the whale, which, being well saturated with oil and grease, was water-tight; and they also used breeches of deer's hide and seal-skin boots, to the upper end of which were fixed strings of sea-horse hide. It was their fashion to tie one of these strings round the waist, and attach to it a long tuft of hair, the wing of a bird, or sometimes a fox's tail, which, dangling behind as they walked, gave them a idiculous appearance, and may probably have occasioned the report of the Tschuktschi recorded in Muller that the people of this country have tails like dogs.*

On the 22d July, the ship anchored in Kotzebue's Sound, and after exploring a deep inlet on its northern shore, which they named Hotham Inlet, proceeded to Chamisso Island, where the Blossom was to await Captain Franklin. A discretionary power had, however, been permitted to Captain Beechey, of employing the period of his stay in surveying the coast, provided this could be done without the risk of missing Captain Franklin. Having accordingly directed the barge to keep in-shore on the look-out for the land-party, he sailed to the northward, and doubling Cape Krusenstern, completed an examination of the coast by Cape Thomson, Point Hope, Cape Lisburn, Cape Beaufort, and Icy Cape, the farthest point reached by Captain Cook. As there were here strong indications of the ice closing in, and his instructions were positive to keep in open water if possible, he determined to return to Kotzebue's Sound, while he despatched the barge under Mr. Elson and M. Smyth to trace the coast to the north-eastward, as far as they could navigate.

On this interesting service the barge set out on 17th August, while Beechey returned towards Kotzebue's Sound. On the night of the 25th they beheld, for the first time in these northern latitudes, a brilliant display of the Aurora Borealis. " It first appeared," says Captain Beechey, " in an arch extending from west-by-north to north-east; but the arch shortly after its first appearance broke up and entirely disappeared. Soon after this, however, a new display began in the direction of the western foot of the first arch,

* Beechey's Voyage, vol. i. p. 341. 
preceded by a bright flame, from which emanated coruscations of a pale straw colour. An almost simultaneous movement occurred at both extremities of the arch, until a complete segment was formed of wavering perpendicular radii. A soon as the arch was complete, the light became greatly increased, and the prismatic colours, which had before been faint, now shone forth in a very brilliant manner. The strongest colours, which were also the outside ones, were pink and green, on the green side purple and pink, all of which were as imperceptibly blended as in the rainbow. The green was the colour nearest the zenith. This magnificent display lasted a few minutes; and the light had nearly vanished, when the north-east quarter sent forth a vigorous display, and nearly at the same time a corresponding coruscation emanated from the opposite extremity. The western foot of the arch then disengaged itself from the horizon, crooked to the northward, and the whole retired to the northeast quarter, where a bright spot blazed for a moment, and all was darkness. There was no noise audible during any part of our observations, nor were the compasses perceptibly affected."* During the royage back to Chamisso Island, where they arrived on the 27th August, they had repeated interviews with the Esquimaux, whose habits and disposition were in no respect different from those of the natives already described. They found them uniformly friendly, sociable, devotedly fond of tobacco, eager to engage in traffic, and upon the whole honest, though disposed to drive a hard bargain. On some occasions they attempted to impose upon their customers, by skins artfully put together so as to represent an entire fish; but it was difficult to determine whether they intended a serious fraud or only a piece of humour, for they laughed heartily when detected, and appeared to consider it a good joke. Their persons, houses, and cookery were all exceedingly dirty, and their mode of salutation was by a mutual contact of noses; sometimes licking their hands and stroking first their own faces, and afterward those of the strangers.t The rapidity with which these people migrated from place to place was remarkable. On one occasion the motions of two baidars under sail were watched by the crew of the Blossom. The

* Beechey's Voyage, vol. i. p. 38\%.

† IVid, p. 345, 321 . 
people landed at a spot near Choris Peninsula, drew up the boats on the beach, turning them bottom upwards, pitched tents, and in an incredibly short time transferred to them the whole contents of their little vessels. On visiting the encampment an hour after, every thing was found in as complete order as if they had been domiciliated on the spot for months; and the surprise of the sailors was raised to the highest by the variety of articles which, in almost endless succession, they produced from their little boats. "From the two baidars they landed fourteen persons, eight tentpoles, forty deer-skins, two kayaks, many hundred-weight of fish, numerous skins of oil, earthen jars for cooking, two living foxes, ten large dogs, bundles of lances, harpoons, bows and arrows, a quantity of whalebone, skins full of clothing, some immense nets made of hide for taking small whales and porpoises, eight broad planks, masts, sails, paddles, \&c., besides sea-horse hides and teeth, and a variety of nameless articles always to be found among the Esquimaux."*

In the mean time, Mr. Elson in the barge proceeded along the shore for seventy miles, as far as a promontory, denominated by Beechey Cape Barrotv, which was afterward discovered to be only distant 146 miles from the extreme point of Franklin's discoveries. Upon this new line of coast posts were erected at various distances, with directions for Captain Franklin, should he succeed in pushing so far to the westward. A frequent communication was opened with the inhabitants, who were found to resemble the other Esquimaux, with the unpleasant difference that their manners were more rude and boisterous, and their conduct in some instances decidedly hostile. Point Barrow, the most northerly part of America yet discovered, formed the termination to a spit of land jutting out several miles from the more regular coast-line. The width of the neck did not exceed a mile and a half; on the extremity were several small lakes, and on its eastern side a village. The danger of being shut in by the ice was now great, and $\mathrm{Mr}$. Elson determined to land, obtain the necessary observations, erect a post, and deposite instructions for Franklin. This plan, however, was frustrated by the violent conduct of the 
natives, who assembled in formidabie numbers, and threatened to attack the crew of the barge, which consisted only of eight men. It was therefore judged prudent to proceed as speedily as possible to the rendezvous at Chamisso Island, which they reached on the 9 th of September, not without considerable difficulty, having been obliged to track the barge round Cape Smyth, through a sea thickly beset with ice, that threatened every moment to close with its impenetrable walls, and cut off their return. The result of Captain Beechey's voyage, and of the expedition undertaken under his orders by Mr. Elson and Mr. Smyth, was the addition of a new and extensive line of coast to the geography of the polar regions. The actual distance between the extreme points reached by Captain Franklin and Mr. Elson being so small, there is every reason to believe that the navigation of this remaining portion will not be attended with any very formidable or insurmountable obstacles.

In the following year Beechey, in obedience to his instructions, returned to Kotzebue's Sound, and recommenced his examination of the coast, in the hope of extending his survey beyond Cape Barrow, and either joining Franklin or collecting some certain intelligence regarding his enterprise. In both objects he had the mortification to fail : he found the posts erected the preceding year and the buried bottles remaining untouched, and the state of the weather rendered it necessary to put about before reaching Icy Cape. It had been previously arranged, that the signal to be used by Franklin, if he arrived on an unknown coast during the night, should be a beacon kindled on the cliffs; and, on passing Cape Krusenstern after dark, their attention was arrested by a large fire blazing on an eminence. Every eye on board was fixed on the welcome light, and every bosom beat with the delightful expectation of soon seeing their friends. The ship was brought-to, and hope almost passed into certainty, as a boat was seen pulling from the shore. On examining her through the telescope by the light of the Aurora Borealis, some sanguine spirits declared they could discern that she was propelled by oars instead of paddles, and it needed only a slight additional exertion of the fancy to be assured that the dress of the crew was European. In the midst of these excited and enthusiastic feelings, the harsh and boisterous voices of the natives suddenly broke on 
their ear, and the pleasing picture which their imagination had been so busy in constructing faded away in a moment, leaving nothing before them but two sorry Esquimaux baidars and their unlovely occupants.

From this point Captain Beechey's voyage presented few features of new or striking interest. In Behring's Strait they were visited by a splendid exhibition of the Aurora Borealis, and under its coruscations of pink, purple, and green rays, which shot up to the zenith in the shape of a gigantic cone, they anchored off Chamisso Island. After the discovery of two capacious harbourz, which they named Port Clarence and Grantley Harbour, they took their final departure from the Polar Sea, on the 6th October, 1827. On the 29th a flight of large white pelicans apprized them of their approach to the coast of California ; and after touching at Monterey and San Blas, they arrived at Valparaiso on the 29th April, 1828. On the 30th June they passed the meridian of Cape Horn in a gloomy snow-storm, and made Rio on the 21 st July. Their voyage from Rio to England was completed in forty-nine days, and they arrived at Spithead on the 12th October, 1828. He found that the expedition of Franklin had preceded him in his return by more than a year, having reached Liverpool on the 26th September, 1827; its transactions occupied two years and nearly eight months, while Beechey had been absent on his voyage three years and a half. 


\section{THE}

\section{NATURAL HISTORY}

OF THE

NORTHERN REGIONS OF AMERICA.

\section{CHAPTER V.}

\section{Introductory Observations.}

Amelioration in the Character of European Intercourse with uncivilized Nations-The Absence of Sandy Deserts a grand Feature in the Physical Attributes of America-General Boundaries of the Districts afterward treated of in Detail-Early Sources of Information regarding the Natural History of North America-General View of the Furcountries-Passages across the Rocky Mountains-Plains and Valleys along the Pacific Shore.

THE preceding historical narrative will have rendered our readers familiar with the progress of navigation and discovery along the shores of North America; while the sketches which have been presented of the journeys of Hearne and Mackenzie, as well as of the more recent expeditions of Franklin and Richardson, will have exhibited an accurate and interesting picture of whatever is most worthy of record in the history and habits of the more central tribes. The unextinguishable boldness and persevering bravery of the human race are strikingly manifested by these achievements in maritime and island adventure; and while we are too often shocked by the recital of deeds of violence and bloodshed, by unprovoked and unpardonable aggression on the part of the invaders, and by unsparing revenge, in retaliation, by the darker savage, we cannot but admire the energy and reckless daring exhibited on either side, though we may too often regret the want of a gentler and more 
humanizing spirit. In regard, however, to the later expeditions, especially those from the British shores, the philanthropist and philosopher must have been alike delighted by the amelioration which has taken place in our mode of intercourse with the "painted men," who are no longer massacred as the beasts that perish, but, even when sought after originally from motives not entirely disinterested, are yet regarded as beings in whom the great Creator has implanted the germ of an immortal life. But by what a catalogue of crimes was the name of Christian first made known to many nations of the Western World; and by what cruel tyranny and the sword of an exterminating war were not the insidious pretences of peace so often followed up by the civilized nations of Europe! The cross was indeed but a vain and hollow symbol in the hands of those blood-stained and avaricious men, who sought to plant upon a false foundation that glorious banner to which God alone giveth the increase. The last entry in the following sumptuous enumeration was probably omitted in the books of those proud traders :- "The merchandise of gold, and silver, and precious stones, and of pearls, and fine linen, and purple, and silk, and scarlet, and all thyine wood, and all manner vessels of ivory, and all manner vessels of most precious wood, and of brass, and iron, and marble, and cinnamon, and odours, and ointments, and frankincense, and wine, and oil, and fine flour, and wheat, and beasts, and sheep, and horses, and chariots, and slaves, and-souls of men."**

We have now to descrilie the characteristic features of the Natural History of the Northern Parts of America, a task rendered comparatively ensy, in many important particulars, by the labours of those intrepid men the recital of whose adventurous expeditions by land and sea has already engaged the attention of the reader. Indeed, we know of no better or more conclusive argument against those who venture to doubt the propriety of scientific exploration, on account of the uncertain fulfilment of some of our most sanguine expectations, than the great advancement which has recently been efiected in our natural knowledge of far countries. It is true that the north-west passage has not yet been achieved, and it may be true that it never will be

* Revelations, xviii. 12, 13 
achieved, consistently with the strictly utilitarian views of merely commercial enterprise : but even although we should never have it in our power to substitute bad muskets for the arrows and harpoons of the skin-clad Esquimaux, and should be for ever doomed to a continuance of our present lengthened navigation to the eastern shores of Asia; still it is something to say that we have almost completed our geographical knowledge of the circumference of the northern parallels of the earth; and that, if the merchant cannot exchange his commodities by a more rapid route, a stock of intellectual food and a rich library both of useful and entertaining knowledge have been already provided, and will doubtless increase for the benefit of future generations. It is to the two expeditions under. Sir John Franklin that we owe the better part of our information regarding the natural history of the interior districts of the fur-countries of North America; and although the collecting of specimens did certainly form but a secondary object in comparison with those great geographical problems, the solution of which was looked forward to as the principal and more important result, yet it is gratifying to know that in the performance of higher duties of dificult and dangerous achievement, these resolute men neglected nothing which could in any way conduce to the completion of our knowledge of the countries they explored.

Before entering into any zoological details, we shall devote a brief space to the consideration of one of the most peculiar and influential features in the physical character of the New World, viz. the absence of sandy deserts. It has been well observed that the physical conformation of North America precludes the possibility of those arid wastes They result from a want of moisture, and attach to such extended plains, in the more immediate vicinity of the tropics, as are too vast and disproportioned in relation to the quantity of rain which nature has assigned them; for there-

\section{"No cloud of morning dew}

Doth travel through the waste air's pathless blue, To nourish those far deserts."

They drink and are for ever dry ; for the castellated glories of cloud-land float over them in vain; and even when rent 
by thunderbolts, or illuminated by the blinding glare of the sed lightning, they never hear the refreshing music of the voice of "many waters." Geographical observation points out that whenever a continent or country is expanded for more than a few hundred miles beneath an equatorial sky, with a surface comparatively low and flat, it will become a desert. This is nothing more than the natural result of its inability to be supplied with moisture. A great proportion of Africa, the central regions of Asia, Arabia, and even those parts of Hindostan where mountains do not prevail, have become steril and deserted. Vast chasms are thus created, in which neither animal nor vegetable life can flourish.

New-Holland probably owes its moisture to its insular situation; and the peniusular form is no doubt highly advantageous in that respect to the regions of Spain, Italy, Greece, and Asia Minor, while the mountain-ridges of Hindostan render it essential service. It is chiefly owing either to the vicinage of the sea, or of some alpine tract of territory, that those parts of Asia and Africa which the great deserts do not reach have become the fit abodes of the human race. Over a great extent of Central Africa, and some parts of Asia, along the coasts of the Red Sea and of the Indian Ocean, there does not seem to exist a sufficiency of mountain-ranges to collect from the atmosphere such stores of muisture as are necessary to fertilize those thirsty plains, and clothe their arid wastes with verdure. No commanding Cordilleras overlook those burning deserts, - no upland vales, nor cool and cloud-capped summits, each with its huge recess,

\section{"That keeps till June December's snow,"}

serve as the peremnial fountains of refreshing water.

Let us briefly consider a few of the leading physical characters of America, with a view to ascertain the cause of its exemption from desert regions. * Within and in the vicinity of the tropic, North America is composed of what

* See a shor paper entitled "The United States are exempt from Deserts, and all the Evils consequent thereon," published in Mr. Featherstonhaugh's Monthly American Journal of Geology and Natural Sicience. Philadelphia, August, 1831. 
may, comparatively, be regarded as a narrow slip. It enjoys all the advantages of an insular position, and is refreshed on either side by the vapours of the translucent sea. Besides, the Cordilleras traverse the whole space, rising upon the Mexican table-land to an elevation of 11,000 feet. All the winds of heaven, and especially the deeply-saturated trades, pour forth their never-ceasing vapours on this well-disposed region, and clothe its lengthened slopes and undulating plains with all the rich luxuriance of a life-sustaining vegetation. mountains, after upheaving the tropical parts of our continent to the regions of eternal verdure, bear aloft their wide-spread arms (the Chipewyan and Alleghany ranges) as far as it is necessary to counteract the heats of a southern sun, and impart fertility to the great valley of the Mississippi, which seems especially confined to their fostering care. But when elevations become no longer essential to the certainty of moisture and vegetation, they sink into the great plains of Canada, and disappear. How wise is this arrangement! For, if these mountains had carried their characteristic elevation far north, they would have chilled with their eternal snows all the northern portion of our country, and rendered it barren,- - not from drought and deserts, but, what is equally to be deprecated, the blights of intolerable cold. These friendly ranges of mountains are thus the everlasting guarantee of our country's fertility. The Alleghany range derives its moisture from the Atlantic, and waters not only all the states that intervene between it and that ocean, but the states and districts that rest upon its western base, and contributes its full part to the great plains of Mississippi and Missouri. The Rocky or Chipewyan range draws heavily from the Pacific Ocean, and abundantly waters, not only that slope, but the extended plains which meet its eastern base. The narrow slopes of the two ranges of mountains which border the two oceans are easily and very naturally irrigated from those oceans; and their slopes, pointing inwards from the oceans and the plains immediately in contact with them, draw moisture from the numerous founts and reservoirs of the mountains themselves. The great valley of the Mississippi, however, is too extensive, and too important to the rising generation of this country, to be left to any 
uncertain supply of moisture. The sources of the mountains with which it is enfiladed might prove to be inadequate, and certainly would, if all depended on them. Other guarantees are found, and powerful aids provided in the case. That great valley opens itself without barrier, on the southern end, to the trade-winds, which become deflected by the Mexican coast, enter it fraught with all the moisture of the gulf, and deposite on this region a supply literally inexhaustible, because those winds themselves are perpetual."*

But even should the vast masses of vapour which gather over these majestic mountains, and are carried thither by the trade-winds, be insufficient to supply with moisture the almost boundless plains of the Western World, Providence has there collected the mightiest reservoirs of fresh water which exist on the surface of the known earth. The vast lakes of Canada, over which the winds are perpetually sweeping, and from which arise innumerable clouds of vapour, ensure a never-failing supply of water to the con tiguous portions of the plain. Thus, table-lands and rocky mountains, a circumambient ocean, and the most magnificent internal reservoirs, all co-operate to ensure, especially to the territory of the United States, a perpetual supply of moisture. The natural fertility of the soil is therefore great, and yields abundantly and with certainty to the wants of man. This humidity is moreover well-tempered, and is rarely poured forth in superabundance. In some northern European countries, and even in Great Britain and Ireland, our own familiar homes, the crops more frequently fail from excess than deficiency of moisture. In the former case, the grain is either blighted in the field, or it moulds and rots in the granary, or acquires a musty smell and flavour which render it unfit for the production of the finer breads.

Wherever deserts prevail to a great extent, they not only prevent vegetation, and, consequently, preclude the possi. bility of a numerous population, but they also exercise a prejudicial influence over all the habitable neighbouring re* gions. They draw from them their moisture, and thus render their vegetation precarious. The heats that steam

\section{$\star$ Ibid.}


from deserts enfeeble the vegetable life of the adjoining districts, and the sirocco-winds, collecting deleterious matters from their fevered surface, carry languor, disease, and death in their course, and convert the verdant freshness of nature into an arid wilderness. When the seasons and the climate of a country are uncertain, when no human effort can control them, and no art or foresight render the results of labour available, the human creature himself partakes of the wildness and irregularity of outward nature, and is either a victim of the wrathful elements, or a fierce and relentless devastator in his turn. Even the very form of man, in connexion with deserts, is deprived of much of its natural symmetry; it is thin, dry, emaciated, and of a black or swarthy hue. He seems there formed, as it were, to drift with the sands, to move his limber and elastic frame with all the quickness that uncertainty may require; but he possesses not the muscular porvers requisite to continuous and effective labour. "In such countries population is sparse, and the few who draw a scanty support from the stinted and uncertain vegetation are unfixed in their habits, and wanderers. They realize nothing-improve not their condition-are actuated by the sudden impulses of want, or the emergency occasioned by the irregularities of the elements around them. If industry exists not, and human labour be unavailable, none of those improvements which change the condition of our race, and give to us character and comfort, have any existence. Without surplus prodıction there can be no commercial exchanges ; a limit is thus placed to social improvement, and a barrier erected against civilization. Man, under such a state of things, cannot multiply his race, because his supply of food is limited,nor create wealth, because his labour is unproductive and without stimulus, -nor make valuable improvements in the arts, comforts, and intercourse of society, because he has neither the means nor the necessary numbers,-nor can he polish and refine himself, because his state of society is essentially wild and violent."* In America the natural condition and consequent tendency of all things is widely different, for the human race is there exempted from deserts and their concomitant evils. Hence a mighty power of fer-

* Festherstonhaugh's Mionthly American Journal, vol. i. p. S@. 
fility is slumbering even among the most unpeopled wastes: and nothing is wanting but the skill and perseverance of man to make the "desert blossom as the rose."

"Pure element of waters ! wheresoe'er

Thou dost forsake thy subterranean haunts,

Green herbs, bright flowers, and berry-bearing plants

Rise into life, and in thy train appear;

And, through the sunny portion of the year, Swift insects shine, thy hovering pursuivants.

But if thy bounty fail, tho forest pants,

And hart and hind, and hnnter with his spear,

Languish and droop together."

The portion of North America with the natural history of which we are now about to be enraged is exclusive of the southern parts of the Canadas, and of the whole of the United States. But it comprehends the entire of those vast territories which lie to the northward of the 48 th parallel, from the northern shore of Lake Superior to Melville Island, in relation to latitude; and from Newfoundland and the eastern cape of Labrador to the peninsula of Alaskin, the western termination of the Russian dominions in America, in regard to longitude.* Those districts are very generally known under the name of the American fur-counlries; and it is indeed to the cmployés of the Hudson's Eay Company and other commercial travellers that we are largely indebted for information regarding the zoological productions of several extensive tracts. For example: the earliest collec tions of the birds of Hudson's Bay were formed about ninety

* In speaking of the boundaries of the almost boundless territorie:; of the Russian dominion, we feel inelined to qualify the expression by the words used in the spirited inscription engraved on the piece of plate presented to Colonel Behm. 'That gentleman was cornmandant of tho province of Kamtschatka in the time of Captain Cook, ard had entertained the great navigator and his crews in a humane and generous spirit. The inscription, of which the composition is graceful, runs as follows:

VIRo EgRegin Magxo DE BenM; qui Imperatricis Augustissima Catherinæ auspiciis, sumnaque animi benignitate, sæva, quibus præerat; Kamtschatkæ littora, navibus nautisque Britannicis hospita præbuit; cosque in rerninis, si qui essent Imperio Russico, frustrà explorandis; mala multa perpessos iterata vice excepit, refecit, recreavit, et com: meatû omni cumulaté auctos dimisit; REI NAVALIS BRITAN:SIC.F SEP: TEMVIRI in aliquam benevolentia tain insignis rnemoriam, amicissirros gratissimoque anins, suo, patriæque nomine, D. D. D. 
years ago by Mr. Alexander Light, who was sent out hy the company in consequence of his knowledge of natural history. It has been also recorded that Mr. Isham, for a long time a resident governor of various forts in the furcountries, occupied his leisure in preparing the skins of heasts, birds, and fishes. These two gentlemen, we are informed by Rr. Richardson, returned to England about the year 1745 , and, fortunately for the advancement of science, intrusted their specimens to Mr. George Edwards, the ingenious author of the " Natural History of Birds, and other rare undescribed Animals,"-a publication which has been characterized as the most original and valuable work of the kind in the English language. In the course of the year 1749, Ellis* and Drage, the latter of whom was clerk to the California, published the respective narratives of their royage, both of which tend to the illustration of natural history.

Jittle information appears to have been received regarding these northern regions for about twenty years succeeding the last-mentioned period. Mr. William Wailes went to Hudson's Bay in 1768 for the purpose of making observations on the transit of Venus, and was intrusted on his return by Mr. Graham, governor of the company's fort at Severn River, with a collection of quadrupeds, birds, and fishes, for presentation to the Royal Society. These specimens were described by John Reinhold Forster, $\ddagger$ and appear to have excited so much attention that the Royal Society requested that directions should be given by the governor and committee of the Hudson's Bay Company, with a view to the more frequent and extensive collection and transmission of objects of natural history. Accordingly several hundred specimens of animals and plants, collected at Fort Albany, were transmitted by Mr. Humphrey Martin. His successor, Mr. Hutchins, was still more industrious; for he not only prepared numerous specimens, but drew up minute descriptions of whatever quadrupeds and birds he could procure. It was in fact from his observations (preserved in a folio volume in the Library of

\footnotetext{
* Voyage to Iivilson's Bay in the Dobte and California

† Voyage by Hudson's Straits.

$\ddagger$ Philosophical Transactions, 1772 .
} 
the Hudson's Bay Company*) that Pennant and Latham chiefly derived whatever was valuable in their workst regarding the feathered tribes of Hudson's Bay. Cook's third voyage threw some light, from circumstances not now very efficient, on the species of the north-west of America and Behring's Straits.‡ Pennant's "Arctic Zoology" was published in 1785, and contains the most ample descriptive catalogue of arctic American quadrupeds and birds which had appeared prior to Dr. Richardson's recent volumes.

These may be regarded as among the more accurate sources of information up to the commencement of our own scientific expeditions by land and sea,- - for although Lmfraville and Hearne no doubt illustrate the habits of some of the more eommon species, and the well-known voyages of Vancouver, Portlock, Meares, and Langsdorff to the north-west,-and the journeys of Lewis and Clarke to the banks of the Columbia, contribute to our stock of knowledge, yet no very important results were thereby obtained. The naturalists attached to Kotzebue's expedition also acquired some information regarding the zoology of the north-west coasts ; and the Appendix to Captain Beechey's Voyage, now in preparation, will probably throw considerable light on those forlorn regions of the world. $\oint$

* For this information we are indebted to Dr. Richardson. Fauna Boreali-Americana, vol. ii., Introduction, p. xi.

+ Arctic Zoology, and General Synopsis of Birds.

$\ddagger$ From the want of engraved representations, and the subsequent destruction or dispersion of the specumens collected, it is now difficult to identify the species with precision.

of We should gladly have availed ourselves of the information contained in the Zoologie:al Appendix to Caytain Beechey's published voyage, which we understand has been for some time printed. It has not yet, however, made its appearance. Few specimens of quadrupeds were brought by that expedition from North America; and we are informed that the only new one was a squirrel from Califoruia. Dr. Rtchardson has supplied a list of all the manmalia known to inhabit the Pacific coast to the north of California. It includes $\% 0$ species, of which the following are not in the Fauna Boreali-Americana: viz. Canis ochropus, Eschschultz, Zoologisch. Atl. pl. 2 ; Filis concolor: F. onca ; six species of seal; Trichtechus rosniarus; Jidelphis Virginiana; Arvicola rubricatus (Ricli.), described from Mr Collie's notes-(this animal was obtained in Behring's Siraits, but no specinen was bronght home; it is allied to Arvicoln aecmomus of Pallas); Arctomys caligata, Eschsch. pl. 6, a suecies resembling Arctomys pruinosus of Pennaut; and Scizrus Collicei (Rich.), from San Blas, Cilifornia.

We are further informed that in this forthcoming Appendix, Mr. Vigors enumerates necrly 100 species of birds; but as the localities at which 
The most exact and systematic information which we possess regarding the zoology of the extreme northern shores and insular groups of Amprica is contained in the Appendices to the Voyages of Captains Ross and Parry, in Mr. Joseph Sabine's Appendix to the Narrative of Sir John Franklin's first Journey, and in Dr. Richardson's "Fauna Boreali-Americana,"-a work lately characterized as an "admirable volume, which, while it conveys more substantial information o:1 the subject of arctic zoology than any publication that has appeared since the time of Pennant, is also highly valuable as correcting the occasional errors of that excellent work, and adding all the most useful and interesting information which has been more recently acquired."* The best account which we yet possess of the zoology of Greenland is that of Otho Fabricius.t The ornithology of that country has likewise been ably illustrated by Captain Sabine. $\ddagger$

We shisil now proceed to give a concise general view of the nature of the different tracts of country of which we are afterward to describe the zoological productions. This we shall do in conformity with the views so lucidly presented by Dr. Richardson. $\oint$

T!ie Rocky Mountains form the most interesting and prominent feature in the physical geography of North America. Though much nearer the western than the eastern shore of that great continent, they appear to form, in relation to the distribution both of plants and animals, a strongly-marked line of demarcation, which presents a barrier to the progress or migration of many species. No doubt, the direction of this vast chain being from south to north, it lies in the line of, rather than at right angles to, the usual course of migration, and therefore opposes a less formidable barricade than if it were stretched across the continent. As it is, however, the natural productions which occur on the plains on difierent sides of this length-

they were procured were not originally noted with precision, it will be the more dillicult to define the ranges of those which characterize the northern regions.

Few northern fishes were obtained : but Mr. Benuet has furnished an account of such as were procured at Kamtschatka.

* Edinburgh Review, No. 106, p. 316. † Famma frenlandica.

$\ddagger$ Memoir on the Birds of Groenland. I,inn. Trans, vol. xii.

f Fauna Boreali-Americana, vol. i., Intoduction, p. xix. xxiy. 
ened range exhibit a considerable dissimilarity. Nature, under the regulation of the latws of Providence, has no doubt made many exceptions to this rule in favour of species which occur on both sides of the chain; but the distribution both of plants and animals, if not regulated, is at least modified by the intervention of these mountains.

This continuous chain, of which the loftiest peak attains to an elevation of 15,000 feet, stretches from II north-west direction, and, p'rsuing a course nearly parallel with the shores of the Pacific Ocean, terminates about the 70th degree of north latitude, to the westward of the mouth of the Nackenzie River, and within sight of the Arctic Sea. Though much inferior in height to the Andes of the sonthern continent, of which, however, in a general sense, they may be regarded as the northern continuation, they greatly exceed in elevation the other mountain-chains of North America. This, indeed, becomes apparent from a consideration of the courses of the great rivers of the country, all of which, with the exception of the lake-born St. Lawrence, derive their sources and primary streams from the Rocky Mountains, however dillerent may be the direction in which their waters tlow. The Columbia, for exaınple, which falls into the Northern Pacific Ocean in the 46th parallel, derives its primary streams from the western slopes of the same rocky chain, the eastern sides of which give rise to the waters of the Missouri, which, following a south-easterly and southern direction, terminate their longcontinued course of 4500 miles in the Gulf of Mexico. The Saskatchawan, in both its great branches, likewise flows from the eastern slopes of the Rocky Mountains, and, uniting its streams a short way below Carlton House, it flows through Lake Winipeg, and then, assuming the name of Nelson River, it empties itself, in the vicinity of Cape Tatnam, into Hudson's Bay. In like manner, the Mackenzie, which, in respect of size, may be regarded as the third river in North America (being inferior to the Missouri and St. Lawrence alone), derives its tivo main branches, the Elk and Peace Rivers, from these mountains; and ere long, flowing northwards and in a north-westerly direction, it opens its numerous mouths into the Polar Sea, after a course of nearly 2000 miles. It may be mentioned as a singular fact, that the Peace River actually rises on the 
western side of the Rocky Mountain ridge, within 300 yards of the source of the Tacootchesse, or Fraser's River, which flows into the Strait of Georgia, on the western shore.*

At a considerable distance below its issue from Great Slave I,ake, and where the Míachenzie makes its first near approach to the Rocky Mountains, it is joined by a large stream which runs a little to the northward of the Feace River, and flows along the eastem base of the mountains. It was called the River of the Mountains by Sir Alexander Mackenzie; but it has since, on account of its great magnitude, become more generally recognised by the traders under the name of the South Branch of the Mackenzie. The Mackenzie also receives several other large streans in the course of its seaward journey, and among others Great Bear Lake River, whose head-waters draw their source from the banks of the Coppermine River, and Peel's River, which issues from the Rocky Mountains in latitude $67^{\circ}$. "Immediately after the junction of Peel's River," Dr. Richardson observes, "the Mackenzie separates into numerous branches, which flow to the sea through a great delta composed of alluvial mud. Here, from the richness of the soil, and from the river bursting its icy chains comparatively very early in the season, and irrigating the low delta with the warmer waters brought from countries ten or twelve degrees farther to the southward, trees flourish, and a more luxuriant vegetation exists than in any place in the same parallel on the North American continent." $\dagger$ In latitude $68^{\circ}$, there are many groves of handsome white sprucefirs, and in latitude $69^{\circ}$, on the desolate shores of the Polar Sea, dense and well-grown willow-thickets cover the flat islands ; while currants and gooseberries grow on the drier hummocks, accompanied by showy epilobiums and perennial lupins. The moose-deer, the heaver, and the American hare follow this extension of a life-sustaining vegetation, and the existence of these herbivorous animals induces a corresponding increase in the localities of wolves, foxes, and other predaceous kinds.

The above-mentioned are the principal rivers which traverse the fur-countries of America. There are, however, a few others of smaller size, the banks of which yielded

* Edinburgh Review, No. 106, p. 352.

† Fauna Boreali-Americaua, vol. i., Jutroluction, p. xxit. 
therr share of the natural history collections, and may therefore be briefly noticed. Hayes River takes its origin from the neighbourhood of Lake Winipeg, and, after running a course almost parallel to that of Nelson's River, it falls into the same yuarter of Huc'son's Bay. York Factory, so frequently mentioned in the narratives of our northern expeditions, stands on the low alluvial point that separates the mouths of these two rivers. The Missinnippi, or, as it is sometimes called, the English River, falls into Hudson's Bay at Churchill. Its upper stream is denominated the Beaver River, and takes its rise from a small ridge of hills, intermediate between a bend of the Elk River and the northern branch of the Saskatchawan. Lastly, the Coppermine River derives its origin not far from the east end of Great Slave Lake, and pursuing a northerly course, already made familiar to our readers, it flows through the Barren Grounds into the Arctic Sea. It is inferior in size to several branches of the Mackenzie; and as there are few alluvial deposites along its banks, it is deficient in that comparative luxuriance of regetation which, along the banks of the Mackenzie, induces several species of herbivorous quadrupeds to seek a higher latitude than they elsewhere attain. Did our limits permit we could dwell with pleasure on this example of the interconnexion or mutual dependence of the links of a lengthened chain of facts in natural history.

There are various practicable passages across the Rocky Mountains. Sir Alexander Mackenzie crossed them in the year 1793, at the head of the Peace River, between latitudes $55^{\circ}$ and $56^{\circ}$. The same route was followed in 1806 by a party of the North-west Company, who went to form a settlement in New-Caledonia. It is still occasionally used by the servants of the Hudson's Bay Company. In the year 1805, Lewis and Clarke effected a passage at the head of the Missouri, in latitude $47^{\circ}$, on their way to the mouth of the Columbia. 1r. Richardson informs us, that for several years subsequent to that period, the North-west Company were in the habit of crossing in latitude 5210 , at the head of the north branch of the Saskatchawan, vetween which and one of the feeding streams of the Columbia there is a short portage; but of late years, owing to the hostility of the Indians, that route has been deserted, and the Hudson's Bay Company, who now engross the whole 
of the fur trade of that country, make use of a more lengthened portage between the northern branch of the Columbia and the Red Deer River, one of the branches of the Elk or Mackenzie. We are likewise informed that atiempts have been recently made to effect a passage in the $62 \mathrm{~d}$ paralle of latitude; but although several ridges of the mountains were crossed, it does not appear that any stream flowing towards the Pacific was attained.

The latest journeys across the Rocky Mountains with which we happen to be acquainted are those of Messrs. Drummond and Douglas, two skilful and enterprising botanists, both belonging professionally to that high class of practical horticulturists for which Scotland has been long famous, and of which she is so justly proud.

Mr. Drummond acted in the eapacity of assistant-naturalist to Sir John Franklin's second overland expedition, and it was to his unrivalled skill in collecting, and indefatigable zeal, that Dr. Richardson was indebted for a large proportion both of the botanical and zoological productions. He continued at Cumberland House in 1825, and occupied himself collecting plants during the month of July, after the main body of the expedition had departed northwards. He then ascended the Saskatchawan for 660 miles, to Edmonton House, performing much of the journey on foot, and amassing objects of natural history by the way. He left Edmonton House on the $22 \mathrm{~d}$ of September, and crossing a thicklywooded swampy country to Red Deer River, a branch of the Elk or Athabasca, he travelled along its banks until he reached the Rocky Mountains, the ground being by this time covered with snow. Having explored the portage-road for fifty miles across the mountains towards the Columbia River, he hired an Indian hunter, with whom he returned to the head of the Elk River, on which he passed the winter making collections, under privations which Dr. Richardson observes, "would have effectually quenched the zeal of a less hardy naturalist." He revisited the Columbia portageroad during the month of April, 1826, and continued in that vicinity until the 10 th of August, after which he made a journey to the head-waters of the Peace River, during which he suffered scverely from famine. But, nothing daunted, our enduring countryman, as soon as he had obtained a supply of provisions, hastened back to the Culumbia 
portage, with the view of crossing to that river, and botanizing for a season on its banks. However, when he had reached the west end of the portage, he was overtaken by letters from Sir John Franklin, informing him that it was necessary to be at York Factory in 1827. He was therefore obliged to commence his return, greatly to his own regret; for a transient view of the Columbia had stimulated his desire to investigate its natural treasures. "The snow," he observes, "covered the sround too deeply to permit me to add much to my collections in this hasty trip over the mountains; but it was impossible to avoid noticing the great superiority of the climate on the western side of that lofty range. From the instant the descent towards the Pacific commences, there is a visible improvement in the growth of timber, and the variety of forest-trees greatly increases. The ferv mosses that I yleaned in the excursion were so fine that I could not but deeply regret that I was unable to pass a season or two in that interesting region." He now reluctantly turned his back upon the imountains, and, returning by Eidmonton House, where he spent some time, he joined Dr. Richardson at Carlton Jouse, on his homeward journey. Mr. Drummond's collections on the mountains and plains of the Saskatchawan amounted to about 1500 species of plants, 150 birds, 50 quadrupeds, and a considerable number of insects. He remained at Carlton House for six weeks after Dr. Richardson had left that place, and, descending to Cumberland IIouse, he there met Captain Back, whom he accompanied to York Factory. He had previously, however, had the pleasure of being joined by a countryman and kindred spirit, Mr. David Douglas, the other indefaticable collector to whom we have already alluded. Mr. Douglas had been engaged in gathering plants for three years for the Horticultural Society, in North California and on the banks of the Columbia River. He had crossed the Rocky Momtains from the westward, at the head of the Elk River, by the same portage-road previously traversed by Mr. Drummond, and having spent a short time in visiting the Red River of Lake Winipeg, he returned to England along with Mr. Drummond by the way of Hudson's Bay.* "Thus, a zone of at least two degrees

* These enterprising nen have been for a consirierable period respecsively engaged $3 n$ is second journey of great extent, through various 
of latitude in width, and reaching entirely across the conti nent, from the mouth of the Columbia to that of the Nelson River of Hudson's Bay, has been explored by two of the ablest and most zealous collectors that England has ever sent forth; while a zone of similar width, extending at right angles with the other from Canada to the Polar Sea, has been more cursorily examined by the expeditions."

That widely-extended tract of territory which lies to the eastward of the Rocky Mountains, and to the north of the Missouri and the Great Lakes, is now well known to the Hudson's Bay traders, with exception of the shores of the Polar Sea, and a corner, bounded to the westward by the Coppermine River, Great Slave, Athabasca, Wollaston, and Deer Lakes, to the southward by the Churchill or Missinnippi, and to the northward and eastward by the sea. When viewed under a zoological aspect, we find that this north-eastern corner, more particularly known under the name of the "Barren Grounds," carries its purely arctic character farther to the south than any of the other meridians. This very bare and desolate portion of America is almost entirely destitute of wood, except along the banks of its larger rivers. The rocks of this district are primitive, and rarely rise to such an elevation as to deserve the name of mountain-ridges, being rather an asscmblage of low hills with rounded summits, and more or less precipitous sides. The soil of the narrow valleys which separate these hills is either an imperfect peat-earth, affording nourishment to dwarf birches, stunted willows, larches, and black spruce-trees,-or, more grenerally, it is composed of a rocky debris, consisting of dry, coarse, quartzose sand, unalapted to other vegetation than that of lichens. The centres of the larger valleys are filled with lakes of limpid water, which are stored with fish, even though frequently completcly landlocked. More generally, however, one of these lakes discharges its waters into another, through a narrow gorge, by a turbulent and rapid stream; and, indeed, most of the rivers which irrigate these barren grounds may almost be viewed as a chain of narrow and connected lakes. The rein-deer or

regions of North America. The different departments of natural history are expected to gain a rich harvest by their zealous and discriminating labours.

* Eauna Borcali-Americana, vol, i., Introduc:ion, p. xviii. 
caribou, and the musk-ox, are the prevailing quadrupeds of these unproductive wastes, where the absence of fur-bearing species has prevented any settlement by the traders. The only human inhabitants are the caribou-eaters, - a people composed of a few forlorn families of the Chipewyans.

From the district above described, a belt of low primitive rocks extends to the northern shores of Lake Superior. Dr. Richardson calculates it 3 width at about 200 miles; and he states that, as it becomes more southerly, it recedes from the Rocky Mountains, and difiers from the Barren Grounds in being well wooded. It is bounded to the eastward by a narrow strip of limestone, beyond which there is a flat, swainpy, and partly alluvial district, forming the western shores of Hudson's Bay. This tract, from the western border of the low primitive tract just mentioned to the coast of Hudson's Bay, has been named the Eustern District, and presents us with several animals unknown to the higher latitudes.

The Eastern District is bounted to the westward by a flat limestone deposite; and a remarkable chain of lakes and rivers, such as the Lake of the Woods, Lake Winipeg, Beaver Lake, and the central portion of Churchill or Missinnippi, all of which lie to the southward of the Methye Portage, marks the line of junction of the two formations. This district, which Dr. Richardson has named the Limestone Tract, is well wooded, and produces the fur-bearing animals in great abundance. The white or polar bear, the arctic fox, the Hudson's Bay lemming, and several other species disappear, while their places are filled up by bisons, bats, and squirrels, unknown to the other regions.

Intermediate between the limestone tract and the foot of the Rocky Mountains, there occurs a wide expanse of what is called in America prairie land. So slight are the inequalities of its surface, that the traveller, while crossing it, is obliged to regulate his course either by the compass or the observation of the heavenly bodies. The soil is tolerably fertile, though for the greater proportion dry and. rather sandy. It supports, however, a thick grassy sward, which yields an abundant pasture to innumerable herds of 
bison, and many species of deer; and the grizzly bear, the fiercest and most powerful of all the North American landanimals, properly so called, inhabits various portions of this wide-spread plain. Prairies of a similar aspect, and still greater extent, are known to border the Arkansa and Missouri rivers. They are said to become gradually narrower to the northward, and in the southern portion of the fur-countries they extend for about fifteen degrees of longitude, from Maneetobaw, or Maneetowoopoo, and Winipegoos Lakes, to the base of the Rocky Mountains. These inagnificent plains are partially intersected by ridges of low hills, and also by several streams, of which the banks are wooded; and towards the skirts of the plains many detached masses of finely-formed timber, and pieces of still water, are disposed in so pleasing and picturesque a manner, as to convey the idea rather of a cultivated English park than of an American wilderness. There is, however, so great a deficiency of wood in the central parts of these plains, that " the hunters," says Dr. Richardson, "are under the necessity of taking fuel with them on their journ'ys, or in dry weaiher of maling their fires of the dung of the bison. To the northward of the Saskatchawan, the country is more broken, and intersected by woody hills; and on the banks of the Peace River the plains are of comparatively small extent, and are detached from each other by woody iracts : they terminate altogether in the angle between the River of the Mountains and Great Slave Lake. The abundance of pasture renders these plains the favourite resort of various ruminating animals." *

The preceding summary brings us to the base of that vasi and continuous chain already so often mentioned under the name of the Rocky Mountains. It is inhabited by many singular animals, some of which do not occur among the lower grounds on either side of the range. We have already stated our opinion regarding the character and physical infuence of this extended group, and as we shall ere long describe the most remarkable of its zoological productions, we shall in the mean time request the reader to descend with us towards the western or Pacific shores. There we

* Fauna Boreali-Americana, vol. i, Introduction, p. xxix. 
find several interesting tracts of country, with the natural history of which we are, however, more imperfectly acquainted than we should desire.

The countries between the Rocky Mountains and the Pacific are in general of a more hilly nature than those already described to the eastward; but the upper branches of the Columbia are skirted by extensive plains, which present the same general character as those of the Missouri and Saskatchawan. New-Caledonia extends from north to south about 500 miles, and from east to west about 350 or 400. Its central post at Stewart's Lake is placed in north latitude 541, and west longitude 125 degrees. According to Mr. Harmon, it contains so many lakes that about one-sixth of its entire surface is under water. The weather here is much milder than on the eastern side of the mountains,-an amelioration which is no doubt owing to the comparatively narrow extent of land which intervenes between the mountains and the sea.* However, for a few days during the depth of winter it must be "pretty considerably" cold, as the thermometer is said to descend for a time to about thirtytwo degrees below zero of Fahrenheit. Snow generally falls about the 15th of November, and disappears by the 15th of May; $\dagger$ from which the winter may be fairly inferred to be of shorter duration by about one-third than it is in some places situated under the same latitude on the other side.

The only remaining district of North America to which we need here allude, as falling within the scope of the present volume, is that forlorn region in the north-west corner of the continent, which forms the terminating portion of the vast Russian dominions. Its shores have been coasted by Cook, Kotzebue, and Beechey ; but of its interior nature and productions we are more sparingly informed. Dr. Richardson, indeed, reports, from information given by the few Indians of Mackenzie's River who have ever crossed the range of the Rocky Mountains in that northern quarter, that on their western side there is a tract of barren ground frequented by rein-deer and musk-oxen; and it may also be

* Edinburgh Review, No. 106, p. 355.

† Journal of Voyages and Travels in the Interior of North America, between the forty-seventh and fifty-eighth degrees of latitude, by Daniel Willian Harmon, a partner in the North-west Company. Andover, 1829. 
inferred, from the quantity of furs procured by the Russian company, that woody regions, similar to such as exist to the eastward of the mountains, also occur in this north-west corner of America.

\section{CHAPTER VI.}

\section{The Quadrupeds of the Norlhern Regrions of America.}

Inaceuracies of some Historical Writers-No Monkeys in North Americe -Bats-Slireivrite?-Ciems Scalops, or Shrewwole-Other Moles of Amerien-The Ftar-mose-Varmes Bears-Dufferent digitated (zuadruperls-The Cimala Guter-The seat-onter-The Dogs and Wolves of America-The Foxes-The beaver - The Musk-rat-Mealow Mice and Lemmings-The Rocky Mountain Neotoma-The American Fitdrnouse-The Marmots - The Squirrel Tribe-The Canada PoreupineThe American Hare - The Polar Hare-The Prairie Hare-'The I,ittle Chief Hare-Cenus Cervis-The Elk, or Moose-deer-The Reio-deer -The Woulland (arthou-The Rocky Mountain Sheep-The Rochy Mountain Cioat-The Bison, or American Buffalo-The Musk-ox.

HAvING in the preceding chapter exhibited a general sketeh of some of the prevailing features in the physical geography of the northern countries of America, we shall now proceed to a more detailed and systematic account of their natural history. But, in the first place, we may notice a slight inaccuracy which prevails in regard to the comparative sice of the ferine inhabitants of the Old and New World. "Nature," says Dr. Rohertson, * "was not only less prolific in the New World, but she appears likewise to have been less vigorous in her productions. The animals originally belonging to this quarter of the globe appear to be of an inferior race, neither so robust nor so fierce as those of the other continent. Americ'a gives birth to no creature of such bulk as to be compared with the elephant or rhinoceros, or that equals the lion and tiger in strength and ferocity. The tapir of Brazil, the largest quadruped of the ravenous tribe in the New World, is not larger than a calf of six monthe old. The puma and jatguar, the liercest beasts of piey, 
which Europeans have inaccurately denominated lions and tigers, possess neither the undaunted courage of the former, nor the ravenous cruelty of the latter. "They are inactive and timid, hardly formidable to man, and often turn their backs upon the least appearance of resistance.t The same qualities in the climate of America which stinted the growth and enfeebled the spirit of its native animals have proved pernicious to such as have migrated into it voluntarily from the other continent, or have been transported thither by the Europeans.t The bears, the wolves, the deer of America, are not equal in size to those of the Old World." $\$$ Now this idea that the quadrupeds of the New World are smaller than those of the Old is correct only in relation to the southern regions of each. The elephant and rhinoceros of India are of much more vast dimensions than the tapir and lama of South America; but "the bears, wolves, and deer" of North America are much larger than those of Europe, and the reptiles of that same quarter of the globe are infinitely larger than any which occur in corresponding latiludes of the ancient continent. Even in regard to the feline tribes which the great Scotch historian considered as so inferior in the New World, perhaps there is less disparity than is usually supposed. Buffon's observations on the "cowardly tigers" of the new continent are known to be applicable to the small specics called the ocelot; and it is ascertained that the real jaguar of the Orinoco sometimes leaps into the water and seizes the Indians in their canoes, - a practice not entirely consistent with the idea of its fearing the face of man. Let us peruse the following passages from the writings of Humboldt:-_"The night was gloomy; the Devil's Wall and its denticulated rocks appeared from time to time at a distance, illumined by the burning of the savanuas, or wrapped in ruddy smoke. At the spot where the bushes were the thickest, our horses were frightened by the yell of an animal that seemed to fol.

+ Buffon, Hist. Nat. tom. ix. p. 87. Margravii Hist. Nat. Brazil, p. 229.

† lliil. ix. 13, 203. Acosta. Hist. lib. iv. c. 31. Pisonis, Hist. p. 6. Herrera, dec. 4, lib. iv. c. 1. lib. x. c. 13.

† Churehili, v. p. 691. Ovalle, Relat of Chili. Churchill, iii. p. 10, Sommatro de (Oviedo. (․ 14-22. Voyage dn Des Marchais, iii. 299.

(I Burfin, Hist. Nat. ix. 103. Kalm's T'ravels, i. 102. Biet. Voy. de France Equinox, p. 333 . 
low us closely. It was a large jaguar that had ronmed for three years among these mountains. He had constanily escaped the pursuit of the boldest hunters, and had carried off horses and mules from the midst of enclosures; but, having no want of food, had not yet attacked men. The negro who conducted us uttered wild cries. He thought he should frighten the jaguar; but these means were of course without effect. The jaguar, like the wolf of Europe, follows travellers even when he will not attack them; the wolf in the open fields and unsheltered places, the jaguar skirting the road, and appearing only at intervals between the bushes."* The same illustrious observer also remarks, "Near the Joval, nature assumes an awful and savage aspect. We there saw the largest jaguar we had ever met with. The natives themselves were astonished at its prodigious length, which surpassed that of all the tigers of India I had seen in the collections of Europe." $\dagger$

The first fact to which we shall here allude is one of a negative character, viz. the entire absence of the monkey tribe, commonly called the Quadrumanous order, from the countries of our present disquisition. The climate is too rigorous and variable for that "pigmy people."

Of the next order, the Cheiroptera or bats, there are several North American species, of which we shall here name only the Vespertilio subulatus of Say, a small-bortied species, common near the eastern base of the Rocky Mountains, on the upper branches of the Peace River and Saskatchawan.

The slender and delicately-formed tribe of shrewmice are well known in America. Forster's shrew (Sorex Forsteri, Rich.) is widely spread over the whole of the fur-countries as far as the sixty-seventh degree of north latitude; and wherever the snow is sufficiently firm to retain the impression, its little footmarks are seen throughout the dreary winter. Dr. Richardson often traced its paths to the top of a stalk of grass, by which it appeared to descend from the surface of the deep snow; but he always sought in vain for its habitation beneath. This is the smallest quadruped with which the Indians are acquainted, and they carefully preserve its 
whin in their conjuring bags. It has been a source of wonder and admiration how the vital power should preserve its delicate limbs from freezing in a country where the winter temperature sinks to fifty degrees below zero. Of this species the tail is of a square form, and of the same length with the head and body, which together measure rather more than a couple of inches. The ears are short and furry, the back is of a clove-hrown colour, and the under parts are pale yellowish brown.

A singular animal (classed under the genus Scalops of Cuvier) is known to the American naturalists by the name of shrewmole. It has a thick cylindrical body, resembling that of the common mole, without any distinct neck. Its limbs are very short, and appear remarkably so in consequence of their being enveloped in the skin of the body as fir as the wrists and ankle-joints. The snout is linear and moveable, and projects above the third of an inch beyond the incisive teeth. The eyes are concealed by the fur, and are so exceedingly small, according to Dr. Godmun, that the aperture of the skin is just large enough to admit the entrance of an ordinary-sized human hair. The paws closely resemble those of the European mole, and the fur has the same rich velvety appearance. It is of a brownish-black colour, with a slight chestnut tinge upon the forehead, and somewhat paler on the throat.

Considerable confusion cxists in the history of the American moles, and it is still a matter of doubt whether any true mole (of the genus Talpa) inhabits the New World. "Before the sun rose," says Sir Alexander Mackenzie, " our guides summoned us to proceed, when we descended into a beautiful valley, watered by a small river. At eight we came to the termination of it, when we saw a great number of moles."* Now, in this country, though molehills are abundant, it seldom happens that we see of the creatures themselves more than one at a time, and even that but rarely. From this it may perhaps be inferred that the species are distinct. However, the one which we have described above is frequent on the banks of the Columbia and the neighbouring coasts of the Pacific. According to J.ewis and Clarke, "it differs in no respect from the species

* Voyages from Montreal, on the river St. Lawrence, through the Continent of North $\Lambda$ merica, to the Frozen and Pacific Qceans, p. 314., $\mathrm{U} 2$ 
so common in the United States."* The northern range of the shrewmole is still unknown. It is supposed not to advance beyond the fifticth degree of latitude, because its favourite food consists of earth-worms, which are unknown in the countries of Hudson's Bay, although it may probably reach a somewhat higher latitude along the milder Pacific shores. Its general habits resemble those of our own kind. It is a subterranean dweller, excavates galleries, throws up mounds, and feeds on insects. This species is said to have the singular custom of coming to the surface exactly at noon. A domesticated individual kept by Mr. Titian Peale was lively, playful, and familiar; it would follow the hand of its feeder by the scent, and then, after burrowing for a short distance in the loose earth, and making a small circuit, would return again for a supply of food. It fed on fresh meat, either cooked or raw, and was observed to drink freely. $\dagger$

Another singular subterranean species is the long-tailed mole of Pennant (Condylura longicaudata, Harlan). The length of this animal, exclusive of the tail, is nearly five inches. It is covered with a brownish-black velvety coat of fur, and the extremity of its snout is furnished with a cartilaginous fringe of eighteen rays, with two short bifid ones beneath the nostrils. It is from these appendages that it has obtained the name of star-nose. Specimens were transmitted to the Zoological Society from Moose Factory, Hudson's Bay. It is called naspass-kasic by the Salteur Indians.

We come now to the group of bears (genus Ursus), which includes the largest and most powerful of the American beasts of prey. It is natural to suppose that animals of almost gigantic size, of great strength, and ferocious habits would be too formidable and dangerous to the human race to remain unknown in any of their distinguishing characteristics. Yet the specific differences of the black and brown bears of Europe and America are still insufliciently illustrated. Both continents produce a black bear and a brown one,-the white or polar bear is com-

* Travels to the Source of the Missouri River, vol. iii. p. 42.

+ American Kistural History, by Jolun D. Godman, M.D., vol. i. p. 84. 
mon to the northern latitudes of each, while America alone is inhabited by the grizzly bear, Ursus fcrox.

The black bear of the New World (Ursus Americanus) has a more arched forehead than the analogous species of Europe. Its nose is continued on the same line with the forehead, and is also somewhat arched, which produces one of its most striking physiognomical characters. Its ears are high, oval, rounded at the tips, and aro placed wide apart from each other. Its fur is long, straight, black, and shining, with the exception of a large pale yellowish-brown spot on each side of the muzzle. The bare extremity of the nose is more obliquely truncated than that of the brown bear, and the palms and soles of the feet are comparatively shorter than in that species. This is the least of the American bears, and seldom exceeds five feet in length. Its disposition is also milder, and its diet consists of a greater proportion of vegetable sulstances. It feeds on various kinds of roots and wild berries, as well as on insects, eggs, birds, quadrupeds, and fish. In short, it may be said to be omnivorous, like the rest of its congeners, with this difference, that when it happens to be amply supplied with a favourite vegetable food, it will pass the carcass of a deer or other quadruped untouched. It may be characterized as rather a timid animal, and seldom ventures to face a human foe, unless when hemmed into a corner, or imboldened by the strength of parental affection. Its speed is generally said not to be very great ; but Dr. Richardson states that he has seen a black bear make off with a rapidity that would have baffled the fleetest runner, and ascend a nearly perpendicular cliff with a facility " that a cat might envy."

This species, when resident in the fur-countries, sleeps throughout the winter, generally under a fallen tree, after having scraped away a portion of the soil. The first heavy fall of snow covers it up, and secures it from an undue intensity of cold. In regard to distribution, it is widely spread over all the wooded districts of America, from Carolina to the Arctic Sea, and across the whole of the continent from east to west. It is, however, less abundant near the seacoasts than in the interior countries. "The skin of a black bear, with the fur in prime order, and the claws appended, was at one period worth from twenty to forty 
guineas, and even more; but at present the demand for them is so small, from their being little used either for muffs or hammercloths, that the best, I believe, sell for less than forty shillings." **

As both the black and grizzly bears vary greatly in the colour of their coats, according to age and season, the supposed brown bear of America is alleged by some to have irisen from one or other of these variations. From inquiries made by Dr. Richardson throughout an extent of ten degrees of latitude, from Lake Superior to Great Slave Lake, he could not ascertain that the natives of these districts were acquainted with more than two species of land bear, viz. the one above described, and the grizzly species. He found, however, that the barren lands which lie to the north and east of Great Slave Lake, and stretch thence to the Polar Sea, are frequented by a bear which differs from those species, and presents a nearer affinity to the brown bear of the Scandinavian peninsula. Its general colour is dusky (sometimes yellowish) brown, and the shoulders and flanks are frequently covered during the summer season with long pale-tipped hairs. This is no doubt the grizzly bear of Hearne, though quite distinct from the kind now more familiarly known under that appellation. The Indians greatly dread the Barren Ground bear, and avoid burning bones, lest the smell should attract so unwelcome a visiter. It is narrated, that as Keskarrah, an old Indian, was one day seated at the door of his tent near Fort Enterprise, a large bear suddenly made its appearance on the opposite bank of a small stream, and remained stationary for some time, curiously eying the old gentleman, and apparently deliberating whether to eat him up at that moment or wait till supper-time. Keskarrah, thinking himself in great jeopardy, and having no one to assist him but a wife as old as himself, immediately gave utterance to the following oration:- "Oh, bear! I never did you any harm; I have always had the highest respect for you and your relations, and never killed any of them except through necessity : go away, good bear, and let me alone, and I promise not to molest you." Bruin instantly took his departure; and the orator, never doubting that he owed his safety to his elo-

* Fauna Boreali-Americana, vol. i. p. 20. 


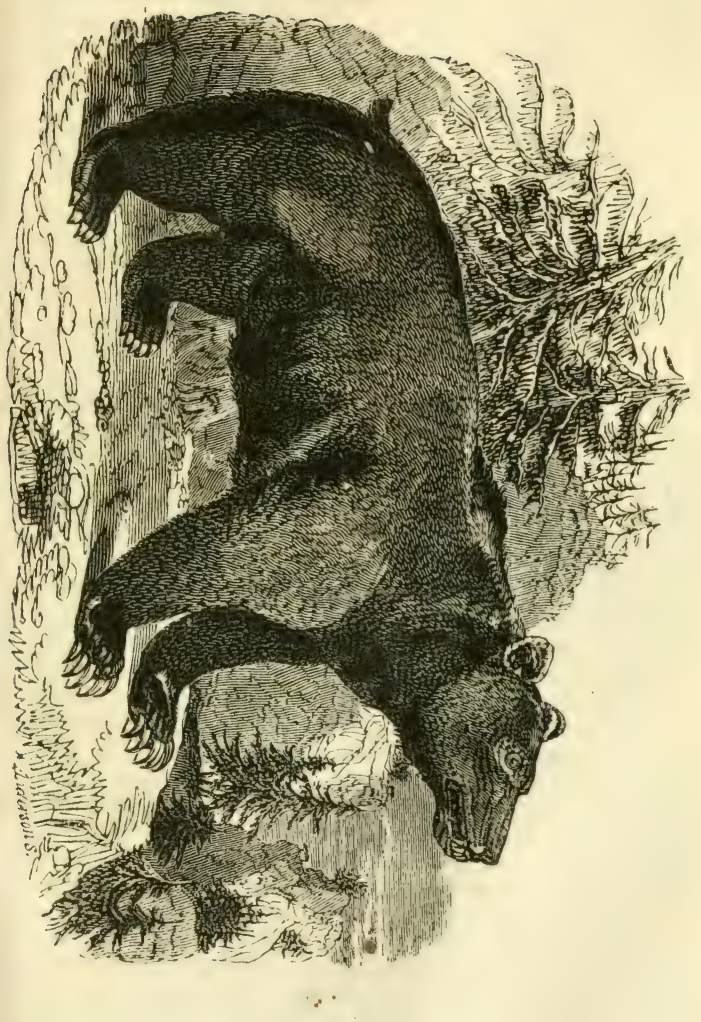



quence, on his arrival at the fort frequently fuvoured the company with his speech at full length. In the stomach of one of these animals which Dr. Richardson dissected, he found the remains of a seal, a marmot, a litrge quantity of the long sweet roots of some Astragali and Hedysart, with some wild berries and a little grass.

The third American species of this genus which we require to notice is the true grizzly bear, or Ursus feroc. He does not present a very amiable aspect.

'This is the most formidable animal of the North American continent. When full grown it equals the size of the larger polar bears, and is not only more active, but of it fiercer and more vindictive disposition. Its strength is so great that it will cirag the carcass of a butfato weighing a thousand pounds. The following story of its prowess is well authenticated :-A party of voyagers had been occupied all day in tracking a canoe up the Saskatchavan, and hat seated themselves around a fire during the evening twilight. They were engaged in the agreeable task of preparing their supper, when a huge grizzly bear sprang over the canoe, which they had tilted behind them, and seizing one of the party by the shoulder, carried him off. The remainder fled in terror, with the sole exception of a metif, named Bourasso, who, grasping his gun, followed the bear as it was deliberately retreating with the man in its mouth. He called out to his unfortunate comrade that he was afraid of hitting him if he fired at the bear; but the latter entreated him to fire instantly, because the animal was squeczing him to death. On this he took a steady aim, and lodged his ball in the body of the brute, which immediately dropped its original prey, that it might revenge itself upon Bourasso. He however escaped, though with dificulty, and the monster soon after retreated into a thicket, where it was supposed to have died. But fear prevailed over every other feeling, and no one thought it necessary too curiously to inquire. The rescued man was found to have had his arm fractured, and to have been otherwise severely bitten; however, he afterward recovered. We are informed by Dr. Richardson, that a man is now living in the vicinity of Edmonton House who was attacked by a grizzly bear, which suddenly sprang out of a thicket and scalped him by a single scratch of its tremendous claws, laying bare the scull, and pulling down 
the skin of the forehead quite over the eyes. Assistance being at hand, the bear was driven off without effecting further injury; but the individual attacked was left in a most unfortunate and painful predicament, for the scalp not being properly replaced in time, he lost his sight (although his eyes remained uninjured), owing to the fixing and hardening of that skinny veil.

Mr. Drummond, whose botanical trip to the Rocky Mountains we have already narrated, frequently met with these disagreeable companions. When he happened unintentionally to come suddenly upon them, they would rear themselves upright on their hind-legs, and utter a loud, harsh, and repid breathing. From what is known of the habits of these animals, it is certain that, had he lost his presence of mind and attempted to flee, he would have been pursued, overtaken, and torn to pieces. But the bold Forfar-man stood his ground to an inch, and beating a huge botanical box, made of tin, his discordant music so astounded the grizzly monsters, that, after eying the Scottish Orpheus for a few minutes, they generally wheeled to the right about and galloped away. He was, however, once attacked by a female who was attended by her cubs. On this oecasiors his gun unfortunately missed fire; but he kept her at bay with the butt-end till some gentlemen of the Hudson's Bay Company, with whom he was at that time traveling, came up to his assistance, and they succeeded in driving her off. On another occasion he observed a male caressing a female, and soon after the loving couple came towards him, but whether by accident or design he was uncertain. However, he thought there was no great harm in climbing a tree, and as the female drew near, he very ungallantly fired at and mortally wounded her. As usual in such cases, she uttered some loud screams, which threw the male into a most furious rage, and he reared himself up against the trunk of the tree on which Mr. Drummond was perched, no doubt wishing himself, if not, like the Scotch baronet's bird, in two places at one time, at any rate in some other quarter of the world than that which he then occupied. However, it is fortunately so ordained that grizzly bears either won't or can't climb, and the female in the mean while having retired to a short distance, lay down, and the male proceeding to condole with her, Mr. Drummond shot bim too. All 
things considered, this was probably his most prudent course.

The geographical distribution of this species is extensive. According to Lieutenant Pike, it extends southward as far as Mexico,* and it is known to inhabit the Rocky Mountains and their eastern plains, at least as far as the sixty-first degree of north latitude, and in the last-named districts it occurs most frequently in such woody regions as are interspersed with open prairies and grassy hills. $\dagger$

Although unwilling to detain our readers much longer in such uncouth company, we cannot close our account of American bears without a short record of the white or polar species,- the Ursus maritimus of naturalists. This great prowler of the arctic snows attains to a higher latitude than any other known quadruped, and dwells indeed by preference

\section{"In thrilling regions of thick-ribbed ice."}

Its southern limit appears to be somewhere about the fiftyfifth parallel. It is well known at York Factory, on the southern shore of Hudson's Bay, more especially during the autumn season, to which it is liable to be drifted during summer from the northward on the ice. It is a truly icehaunting and maritime species, and occurs along a vast extent of shore over the arctic regions, never entering into wooded ccuntries except by accident during the prevalence of great mists, nor showing itself at more than a hundred miles' distance from the sea. Indeed it rarely travels inland more than a few miles, because it is a strong and persevering swimmer, and probably feels conscious that when removed from its accustomed element it loses the advantage of its own peculiar and most powerful locomotive energies. The polar bear is well known in Greenland, Spitzbergen,

* Travels on the Missouri and Arkansaw, edited by Mr. Rees. London, 1811.

† The specimen in the Edinburgh Museum (of which I have published a coloured representation on the twenty-first plate of the first volume of my "Illustrations of Zoology") was killed on the plains at Carlton House in its second year. Its claws are black. In a mature condition these weapons are white, and necklaces made of them are much prized by the Indian warriors as proofs of prowess. 
and Nova Zembla, and was met with ly Captain Parry among the North Ceorgian Islands. It seems, however, to decrease in numbers to the westward of Melville Island. In proof of this it may be mentioned that Dr. Richardson met with none between the mouths of the Mackenzie and Coppermine Rivers ; and the Esquimaux informed Captain Franklin that white bears very rarely visited the coast to the westward of the Mackenzie. Alone the Asiatic shores, on the other hand, they are not recorded as occurring to the eastward of the Tuchukotzkoi Noss.* Neither were they seen by Captain Befchey during his recent royage to the Icy Cape, althourh their skins appear to hatve been procured among other peltry from the natives on the coast of Hotham's Inlet, Kotzebue's sound. $t$ It thus appears that this great maritime species occurs very generally along all the frozen shores within the arctic circle, with the cxception of about thirty-five degree of longitude on either side of Point Beechey, in which it is comparutively rare; and that in Hudson's Bay, and along the northern coast of Labrador, and the nearer portions of Eist and West Greenland, it occurs not unfrequently six or eight degrees to the south of the arctic circle. $f$

We deem it umnecessary to describe the external characters or appearance of this familiarly-known animal. $\oint$

Passing over the racoon (Procyon lotor), the American badger (Meles Labradoria), the wolverene (Gulo luscus), the common weasel (Mustcla vulguris), the ermine or stoat (M. ermineu), the vison-weasel (MI. vison), the pine martin (MI. martes), the pekan or fisher (M. Canadensis), and the Hudson's Bay skunk (Miphitis Americana), we shall devote a page to the history of the American otters.

* Arctic Zoology; vol. i. p. 62 .

† Narrative of a Voyage to the Pacific and Behring's Straits, to cooperate with the Polar Expeditions. London, 1831.

‡ Edinburgh Review, No. 106, p. 344.

$\$$ One of the finest specimens in Europe is preserved in the Edinburgh College Museum. It was shot during one of Sir Edward Parry's expeditions, and was transmitted to Professor Jameson by order of the Lords of the Admiralty. For anecdotes illustrating the history and habits of the polar bear, we beg to refer the reader to No. XIV. of the Family Library, entitled "Discovery and Adventure in the Polar Seas and Regions." 
The Canada ofter (Lutra Canadensis of Sabine) ${ }^{*}$ frequents the neighbourhood of falls and rapids during the winter season; and when its accustomed haunts are frozen up, it will travel a great way over the snow in seareh of open water. In its food and habits it bears a close resemblance to the European species, but it may be distinguished by the fur on the belly being of the same shining brown colour as that on the back. It is also a much larger animal, and has a proportionately shorter tail.

The sea-otter (Lutra murina) belongs to the subgenus Enliyelra of Dr. Fleming.t It exhibits the manners rather of a seal than of a land animal. It resides chiefly in the water; and, according to Pennant, has been sometimes met with more than a hundired leagues from shore. It is dislinguished from the fresh-water species, among other characters, by the larger size and greater strength of its forepaws. The fur varies in beauty according to the age and condition of the animal. Those in highest estimation have the belly and throat interspersed with brilliant silver hairs, while the other parts consist of a thick black coat, with a silky gloss of extreme fineness.

We have now to notice the wolves and dogs of America. The former may be called wild-dogs, and some of the latter are little better than semi-donesticated wolves. We shall not here enter into the question of the specific identity or distinction of the European and American species. The large brown wolf, described by Lewis and Clarke as inhabiting not only the Atlantic countries but the borders of the Pacific and the mountains in the vicinity of the Columbia River, appears to form the closest approximation to the wolf of the Seandinavian Alps and the Pyrenees. It is not found on the Missouri to the westward of the Platte. Wolves were extremely numerous in some of the countries traversed by our overland expeditions. They viried greatly in colour; some being pure white, others totally black, but the greater proportion were characterized by a mixture of cray, white, and hrown. Dr. Richaruson is of opinion that, however coloured, they possess certain characters in common in which

* Appendix to Franklin's First Journey, p. 653.

† Philosephy of Loolugy, rol. ii. p. 18\%. 
they differ from the European rase. "On the Barren Grounds, through which the Coppermine River flows, I had more than once an opportunity of seeing a single wolf in close pursuit of a rein-deer; and I witnessed a chase on Point Lake when covered with ice, which terminated in a fine buck rein-deer being overtaken by a large white wolf, and disabled by a bite in the flank. An Indian, who was concealed on the borders of the lake, ran in and cut the deer's throat with his knife, the wolf at once relinquishing his prey and sneaking off. In the chase the poor deer urged its flight by great bounds, which for a time exceeded the speed of the wolf; but it stopped so frequently to gaze on its relentless enemy, that the latter, toiling on at a ' long gallop,' with its tongue lolling out of its mouth, gradually came up. After each hasty look, the poor deer redoubled its efforts to escape ; but, either exhausted by fatigue, or ener vated by fear, it became, just before it was overtaken, scarcely able to keep its feet." * A wolf seldom fails to attack, and can easily run down a fox, if it perceives it at any considerable distance from its cover, and it bears it off in its mouth without any apparent diminution of its speed, if it he at that time perceived and pursued by the hunters. Though cruel and bloolthirsty, and even at times bold in search of food when severely pressed by famine, the wolf is on the whole a timid and fearful animal. A handkerchief tied to a tree, or a distended bladder dangling in the air, is sufficient to keep a whole herd at a respectful distance. However, during Dr. Richardson's residence at Cumberland House, in 1820, a wolf which had been for some time prowling about the fort, and was supposed to have been lriven off by a wound of a musket ball, returned after nightfall and carried off a dog from among about fifty of his companions, all of whom howled most lamentably, but wanted courage to rescue their unfortunate comrade. In the northern countries of America many wolves suffer dreadfully from famine, and not unfrequently perish of hunger during severe seasons.

The individual here figured, from the fine specimen in the Edinburgh Museum, was found lying dead on the snow near Fort Franklin. It had been observed prowling about

* Fauna Boreali-Americana, vol. i. p. 63. 


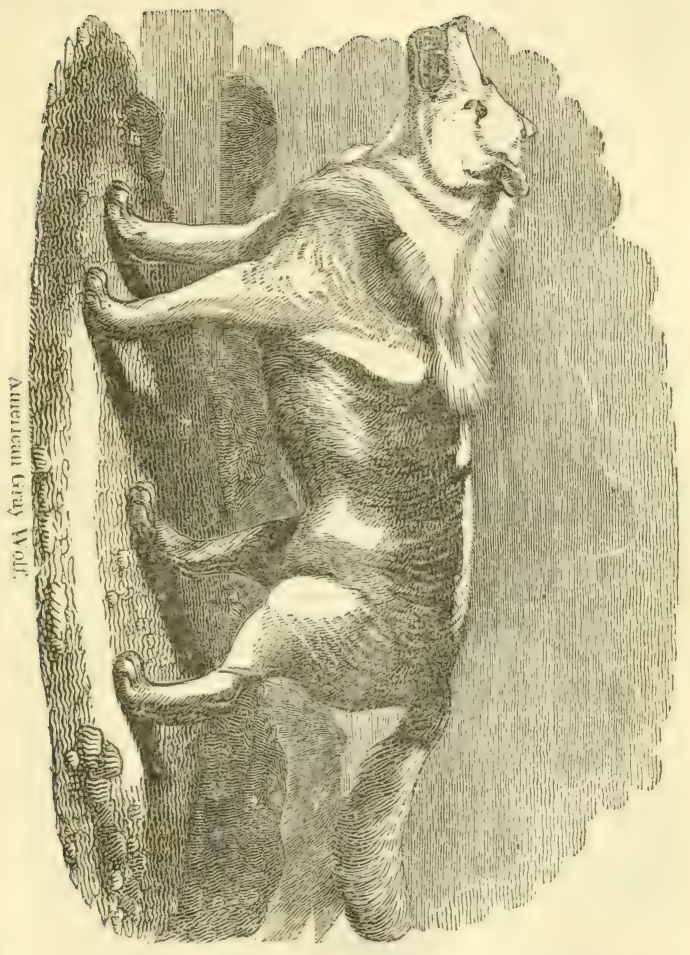



the Indian huts in the vicinity of the fort a few days preceding; and its extreme emaciation and the emptiness of its interior showed clearly that it had died from bunger. Captain Lyon describes the wolves of Melville Peninsula as comparatively fearless. One afternoon a fine dog strayed a short way ahead of its master, when five wolves made a sudden and unexpected rush, and devoured it in so incredibly short a time, that before Mr. Elder, who witnessed the attack, could reach the scene of action, the dog had disappeared, with the exception of the lower part of a leg. They frequently came alongside the frost-bound ship, and one night broke into a snow-hut, and carried away a brace of Esquimaux dogs, which appeared to have made a considerable resistance, as the ceiling was sprinkled with blood and hair. The alarm was not given till the mortal strife had terminated, and when they were fired at, one of the wolves was observed to take up a dead dog in his mouth, and to set off with it at an easy canter, although its weight was supposed to be equal to his own.*

The dusky wolf, described in Godman's Natural History, is regarded as a distinct species by Mr. Say ; $\dagger$ and the black variety is also considered by some authors as entitled to specific separation. The not unfrequent occurrence of black individuals in the litter of the gray and brown wolves seems, however, rather to point out the probability of this difference of colour being merely an accidental variation.

But the prairie wolf (Canis latrans) is undoubtedly a distinct and well-defined species. It hunts in packs, and is an animal of great swiftness. It occurs on both sides of the Rocky Mountains; but is less numerous on the banks of the Columbia than in the plains of the Missouri and Saskatchawan. When the hunters on the banks of the latter river discharge their muskets at any kind of game, great numbers of the prairie wolf are sometimes seen to start from holes in the earth, and keep a look-out with a view to secure the offals of the slaughtered animal. With the exception of the prong-horned antelope, there is probably no swifter quadruped in America than the prairie wolf.

These fierce and unreclaimed animals conduct us naturally to the domesticated tribes of the canine race, of which

* Lyon's Private Journal.

† Long's Expedition to the Rocky Mountains. 
there are several remarkable varieties in the northern regions of America. We can here afford space only for a few lines regarding the Hare Indian or Mackenzie River dog (Canis familiaris, var. lngopos). The front figure of the anmexed cut represents his extermal aspect.

This domestic variety, as far as Dr. Richardson could learn, appeared to be cultivated only by the Hare Indians, and other tribes frequenting the horders of the Great Slave Lake, and the banks of the Mackenzie. It is too small and slight to serve as a beast of draurht or other burden, and is consequently used solely in the chase. It is an animal of a playful and affectionate disposition, easily conciliated by kindness. It has a mild countenance, a demure expression, a small head, slender muzzle, erect ears, and eyes somewhat oblique. Its legs are rather slender, the feet broad and hairy, the tail bushy, and for the most part curled over the right hip. It may be characterized as bearing the same near relation to the prairie wolf as the Esquimaux dog does to the great gray wolf of America. Indeed the whole of the canine republic in these parts of America are of very wolfish habits. For example, the larger dogs which our expedition purchased at Fort Franklin for the purposes of draught were in the habit of pursuing the Hare Indian dogs in order to devour them ; but the latter, fortunately, far outstripped the others in speed. A young puppy, which Dr. Richardson purchased from the Hare Indians, became greatly attached to him, and when about seven months old, ran on the snow, by the side of his sledge, for 900 miles, without suffering from fatigue. "During this march it frequently, of its own accord, carried a small twig or one of my mittens for a mile or two; but although very gentle in manners, it showed little aptitude in learning any of the arts which the Newfoundland dogs so speedily acquire of fetching and carrying when ordered. This dog was killed and eaten by an Indian on the Saskatchawan, who pretended that he mistook it for a fox."

The flesh of dogs is much esteemed by the Canadian royagers, and by several of the Indian tribes. The Chipewyans, however, who deem themselves descended from a dog, hold the practice of using it as an article of food in great abhorrence. 


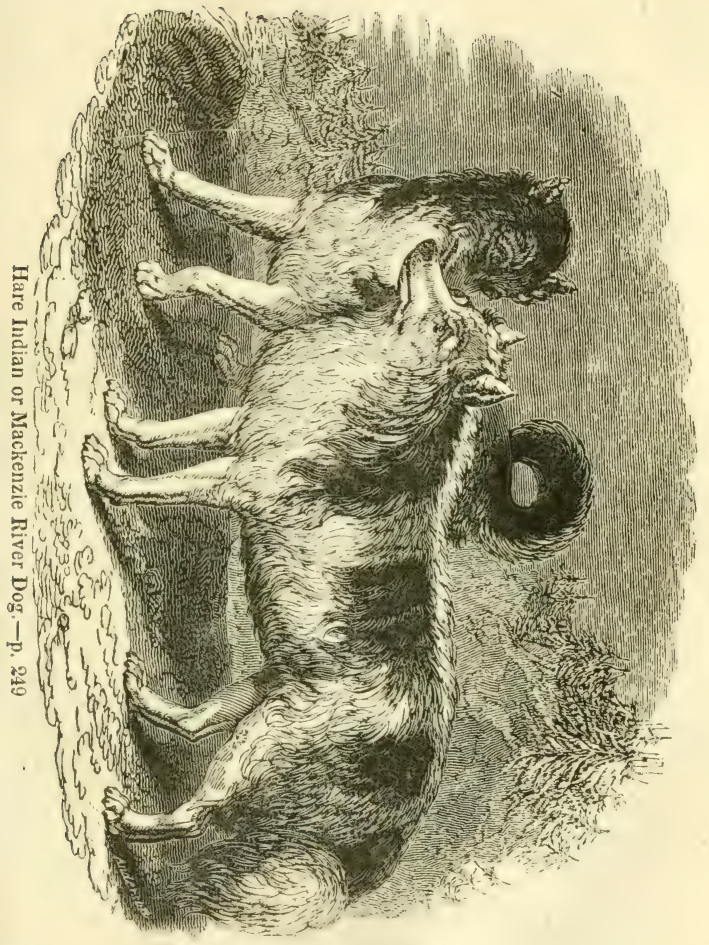



1 here are many species of fox in-North America. The American red fox (Canis fulvus) inhabits the woody districts of the fur-countries, and from thence about 8000 of the skins are annually imported into England. Pennant, and many other authors of last century, regarded the species as identical with the common European kind ; from which, however, it was shown by M. Palisot de Beauvois to be quite distinct. The American species is distinguished by its longer and finer fur, and more brilliant colouring. Its cheeks are rounder; its nose thicker, shorter, and more truncated; its eyes are nearer to each other, and its feet are in general much more woolly beneath. The red fox has a finer brush, and is altogether a larger animal than the European; yet it does not possess the continuous speed of the latter; it seems to exhaust its strength almost at the first burst, and is then overtaken without much difficulty, either by a mounted huntsman or a wolf. The cross fox (C. decussatus) and the black or silver fox (C. argentatus) are considered by some as distinct species, while others, probably with greater correctness, view them in the light of local or accidental varieties. Besides these, we may name as American species, the kit-fox (C. cincreo-argentatus), and the arctic fox, commonly so called (C. lagopus). The latter occurs also in the Old World.

Several kinds of lynx inhabit North America; but we shall not here enter on their history.

We cannot, however, so slightly pass the beaver of these northern regions (Castor fiber, Americanus), one of the most valuable and noted of quadrupeds. Its description is contained in almost every book of natural history ; and we shall therefore confine ourselves in this place to such particulars as illustrate its general habits. As the history of this animal given by Hearne has been characterized by competent authority as the most accurate which has yet been presented to the public, we shall here abridge it for the benefit of our readers.

As the beaver not only furnishes an excellent food, but is highly valuable for the sake of its skin, it naturally attracted the particular attention of the last-named traveller. The situation of beaver-houses was found to be various. When the animals are numerous they inhabit_lakes, ponds, and 
rivers, as well as those narrow creeks which connect the lakes together. Generally, however, they prefer flowing waters, probably on account of the advantages presented by the current in transporting the materials of their dwellings. They also prefer deepish water, no doubt because it affords a better protection from the frost. It is when they build in small creeks or rivers, the waters of which are liable to dry or be drained off, that they manifest that beautiful instinct with which Providence has gifted them-the formation of dams. These differ in shape according to their particular localities. When the water has little motion the dam is almost straight; when the current is considerable it is curved, with its convexity towards the stream. The materials made use of are drift-wood, green willows, birch, and poplars; also mud and stones intermixed in such a mamner as must evidently contribute to the strength of the dam; but there is no particular method ohserved, excent that the work is carried on with a regular sweep, and all the parts are made of equal strength. "In places which have been long frequented by beavers undisturbed, their dams, by frequent repairing, become a solid bank, capable of resisting a great force both of ice and water; and as the willow, poplar, and birch generally take root and shoot up, they by degrees form a kind of regular planted hedge, which I have seen in some places so tall that birds have buili their nests among the branches." *

The beaver-houses are built of the same materials as the dams; and seldom contain more than four old and six or eight young ones. There is little order or regularity in their structure. It frequently happens that some of the larger houses are found to have one or more partitions, but these are only parts of the main building left by the sagacity of the beavers to support the roof; and the apartments, as some are pleased to consider them, have usually no communication with each other, except by water. Those travellers who assert that the beavers have two doors to their dwellings, one on the land side and the other next the water, manifest, according to Hearne, even a greater ignorance of the habits of these animals than those who assign to them an elegant suite of apartments,-for such a con- 
struction would render their houses of little use, either as a protection from their enemies, or as a covering from the winter's cold.

It is not true that beavers drive stakes into the ground when building their houses; they lay the pieces crosswise and horizontal; neither is it true that the woodwork is first finished and then plastered ; for both houses and dams consist from the foundation of a mingled mass of mud and wood, mixed with stones when these can be procured. They carry the mud and stones between their fore-paws, and the wood in their mouths. They always work in the night and with great expedition. They cover their houses late every autumn with fresh mud, which freezes when the frosts set in, and becomes almost as hard and solid as stone; and thus neither wolves nor wolverenes can disturb their repose. When walking over their work, and especially when about to plunge into the water, they sometimes give a peculiar flap with their tails, which has no doubt occasioned the erroneous belief that they use these organs exactly as a mason uses his trowel. Now a tame beaver will flap by the fireside where there is nothing but dust and ashes; and it therefore only uses the trowel in common with the water-wagtail,-in other words, the quadruped as well as the bird is characterized by a peculiar motion of its eaudal extremity.

The food of this animal consists chiefly of the root of the plant called Nuphar luteum, which bears a resemblance to a cabbage-stalk, and grows at the bottom of lakes and rivers. It also gnaws the bark of birch, poplar, and willow trees. In summer, however, a more varied herbage, with the addition of berries, is consumed. When the ice breaks up in the spring, the beavers always leave their houses and rove about until a little before the fall of the leaf, when they return again to their old habitations, and lay in their winter stock of wood. Hearne gives the following account of some tame beavers which belonged to him;- "In cold weather they were kept in my own sitting-room, where they were the constant companions of the Indian women and children, and were so fond of their company that when the Indians were absent for any considerable time, the beavers discovered great signs of uneasiness, and on their return showed equal marks of pleasure, by fondling on them, 
crawling into their laps, lying on their backs, sitting erect like a squirrel, and behaving like children who see their parents but seldom. In general, during the winter, they lived on the same food as the women did, and were remarkably fond of rice and plum-pudding; they would eat partridges and fresh venison very freely, but I never tried them with fish, though I have heard they will at times prey on them. In fact, there are few graminivorous animals that may not be brought to be carnivorous."* According to Kalm, Major Roderfert, of New-York, had a tame beaver above half a year in his house, where it went about quite loose like a dog. The major gave him bread, and sometimes fish, of which he was said to have been greedy. He got as much water in a bowl as he wanted, and all the rags and soft things he could meet with he dragged into a corner, where he was accustomed to sleep, and made a bed of them. The house cat on one occasion, happening to produce kittens, took possession of the beaver's bed without his offering her any opposition. When the cat went out the beaver often took a kitten between his paws, and held it to his breast, as if for the purpose of keeping it warm; but as soon as the proper parent returned he delivered up the offspring. $t$

Another well-known amphibious quadruped of America is the musk-rat, or musquash (Fiber Zibethicus). Its fur resembles that of the beaver, but is shorter; the down is coarser and less valuable, and the more lengthened part of the coat is weaker and not so shining. It is easily wetted after death, although it resists the water well when the animal is alive. The musk-rat measures about fourteen inches, exclusive of the tail, which is eight or ten inches long. It has a strong smell of musk, especially in the spring. Its flesh, however, is eaten by the Indians ; it resembles flabby pork. This species extends from the thirtieth to about the seventieth degree of north latitude. "Their favourite abodes are small grassy lakes or swamps, or the grassy borders of slow-flowing streams, where there is a muddy bottom. They feed chiefly on vegetable mat-

* Hearne's Journey to the Northern Ocean.

$\uparrow$ Kalm's Travels in North America. 
ters, and in northern districts principally on the roots and tender shoots of the bulrush and reed mace, and on the leaves of various carices and aquatic grasses. The sweet flag (Acorus calamus), of whose roots, according to Pennant, they are very fond, does not grow to the northward of Lake Winipeg. In the summer they frequent rivers, for the purpose, it is said, of feeding upon the fresh-water muscles. We ofter saw small collections of muscle-shells on the banks of the larger rivers, which we were told had been left by them."**

Before the frosts set in, the musquash builds a house of mud, of a conical form, with a sufficient base to elevate the chamber above the level of the water. It generally chooses a spot covered with long grass, which it incorporates with the mud. It uses no kind of composition with which to agglutinate these materials; but there is usually a dry bed of grass deposited within the chamber. The entrance is under water. Dr. Richardson informs us that when ice forms over the surface of the swamp, the musquash makes breathing-holes through it, and protects them from the frost by a covering of mud. During severe winters, however, these holes are frequently frozen up, and many die. Hats are manufactured from the skins of these animals; and for that purpose between four and five hundred thousand are imported into Great Britain every year.

Several species of meadow-mice and lemmings (Gen. Arvicola and Georychus) inhabit the northern regions. Our restricted limits, however, do not admit of our particularizing these tribes.

An animal equalling the Norway rat in size, and mentioned by Letvis and Clarke under the name of rat of the Rocky Mountains, was described in the Zoological Journal, + and is now known as the Rocky Mountain neotoma (N. Drummondii, Rich.). It is of a yellowish-brown colour above, white beneath, with a tail exceeding the length of the body, and bushy at the extremity. According to $\mathrm{Mr}$. Drummond, it makes its nest in the crevices of rocks, seldom appearing in the daytime. It is a very destructive animal in stores and encampments. It gnaws furs and

* Fauna Boreali-Americana, vol, i. p. $11 \%$.

† No. 12, March, 1828, p. $\$ 17$. 
blankets to pieces, and $\mathrm{Mr}$. Drummond, having placed a pair of stout English shoes on a shelving rock, found on his return that they had been minced into fragments as fine as sawdust.

Though neither the black nor brown rat, nor the common mouse of Europe, are native to America, they now occur by importation in many parts of the New World. The American field-mouse (II L leucopus) becomes an inmate of the dwelling-houses as soon as they are erected at any trading port. In the northern districts it extends across the whole country from the shores of Hudson's Bay to the mouth of the Columbia. "The gait and prying actions of this little creature," says Dr. Richardson, "when it ventures from its hole in the dusk of the evening, are so much like those of the English domestic mouse, that most of the European residents at Hudson's Bay have considered it to be the same animal, altogether overlooking the obvious differences of their tails and other peculiarities. The American field-mouse, however, has a habit of making hoards of grain or little pieces of fat, which I believe is unknown of the European domestic mouse; and, what is most singular, these hoards are not formed in the animal's retreats, but generally in a shoe left at the bedside, the pocket of a coat, a nightcap, a bag hung against a wall, or some similar place."* This species may be regarded as the representative of the Mus sylvaticus of Europe. Its most inveterate foe is the ermine or stoat, which pursues it even into the sleeping apartments.

Many marmots inhabit North America. $\dagger$ Of these, however, we shall here make mextion of only a single species, the wistonwish or prairie marmot (Arctomys Ludovicianus). This animal is called prairie dog by Sergeant Gass $\ddagger$ and Lieutenant Pike, $\oint$ and it is also the barking-squirrel of

* Fauna Boreali-Americana, vol, i. p. 142.

† For a detailed account of these animals see Mr. Sabine's paper in Linn. Trans, vol, xiii.; the Appendix to Franklin's First Journey; Dr. IIarlan's Fauna Americana; Dr. Godman's American Natural History ; Griffith's Animal Kingdom; Pallas's Novæ Species Quadrupedium o Glirium Ordine; Pennant's Arctic Zoology; and Dr. Richardson's work so frequently above referred to.

$\ddagger$ Journal of the Travels of a Corps of Discovery, \&c.

Travels on the Missouri and Arkansaw. 
Lewis and Clarke.* The entrance to the burrows of this species descends at first vertically, and then continues downwards in an oblique direction. They occur at intervals of twenty feet, and when numerous they are called prairic dog villages. The animals delight to sport about their own doors in pleasant weather. On the approach of danger, they either retreat to their holes or sit for a time barking and flourishing their tails, or sitting in an erect position, as if to reconnoitre. When shot by the hunter, they generally tumble into their burrows, and are thus not easily laid hold of, either dead or alive. They pass the winter in a state of torpidity, and lay up no provisions. The sleeping apartments consist of neat globular cells of fine dry grass, with a small aperture at the top,-the whole so compactly formed that it may almost be rolled over the floor without being damaged. The warning cry of this animal bears some resemblance to the hurried barking of a small dog. $\dagger$

The squirrel-tribe are also very numerous in the countries now under consideration. The chickaree or Hudson's Bay squirrel (Sciurus Hudsonius, Pennant) inhabits the forests of white spruce-trees which cover so vast a portion of the fur-countries. It extends as far to the south as the middle states of America, and spreads northwards to the utmost regions of the spruce-forests, which cast their sombre shade as high as the sixty-ninth parallel. It burrows at the root of the largest trees, and seldom stirs abroad during cold or stormy weather; but even in the depth of winter it may be seen sporting among the branches whenever the snow is brightened by a gleam of sunshine. When pursued it makes great leaps for a time from tree to tree, but ere long seeks a favourable opportunity of descending into a burrow. However, it seldom voluntarily quits its own particular tree. During the winter season it collects the spruce-ccines, and carrying them to the outskirts of its burrow, it picks out the seeds beneath the snow.

Of the flying-squirrels of America we may mention the species (or variety?) discovered by Mr. Drummond on the Rocky Mountains (Pteromys Sabrinus, var. B. alpinus.) It

* Travels to the Pacific Ocean.

† Say's Notes to Long's Expedition to the Rocky Mountaing. 
inhabits dense pine-forests, and rarely ventures from its re. treats except during the night.

Passing over the sand-rats (genus Geomys, Rafinesque),* and the genus Aplodontia of Richardson, + we shall give a short account of the Canada porcupine (Hystrix pilosus of Catesby, $H$. dorsata, Linn.). This singular animal is distributed over a considerable extent of America, from the thirty-seventh to the sixty-seventh degree of north latitude. Dr. Harlan informs us that it makes its dwelling-place beneath the roots of hollow trees. It dislikes water, is cleanly in its habits, sleeps much, and feeds principally on the bark and leaves of Pinus Canadensis and Tilia glabra. It has been known to strip a tree entirely of its leaves, and is also fond of sweet apples and Indian corn. When discovered on the ground this animal does not strive to get out of the way; but, on being approached, it immediately spreads the spines near the tail over the whole of the back. The female brings forth annually three or four young at a birth, after a gestation of forty days.

In the fur-countries the porcupine is most numerous in sandy districts covered with Pinus Banksiana, on the bark of which it delights to feed, as well as on that of the larch and spruce-fir, and the buds of the various kinds of willows. The Indian dogs do not decline to attack this "fretful" creature, and they soon kill it, though not without injury to themselves; for its quills, which it never fails to erect when attacked, are dangerous from the minute teeth, directed backwards, with which they are furnished. The points are extremely sharp, and are no sooner lodged beneath the skin of an assailant than they begin to bury themselves, and finally produce death by transfixing some vital organ. These spines are detachable by the slightest touch, or, as some say, by the will of the animal, and soon fill the mouths of the dogs by which it is attacked, and seldom fail to kill them, unless carefully picked out by the Indian women. Wolves also sometimes die from the same cause. $f$ Its flesh tastes like flabby pork, and though by no means

$\uparrow$ Zoological Journal, January, 1819.

+ Eauna Boreali-Americana, vol. i. p. 215. 
agreeable to European palates, is much relished by the In dians. The quills are variously died, and are used in the working of different ornaments and articles of huntingapparel.

There are four species of hare in North America. We shall give a short history and description of each.

1st, The American hare, commonly so called (Lepus Americanus, Erxleben). This species bears a great resemblance to the European rabbit. It seldom weighs more than four pounds. In winter it is covered with a thick coat of fine long fur, externally of a pure white colour, except a narrow border on the posterior margins of the ears, and round their tips, and about one-third down their anterior margins, which are blackish-brown, on account of the dark roots of the hair being visible. In summer the fur of the upper parts is shining blackish-gray at the roots, but tinged towards the tips with yellowish-brown and black. There is a large proportion of black on the back, and the resulting colour of the surface is a dark umber-brown, mixed with yellowishbrown. A white circle surrounds the eye. The white colour commences between the fore-legs, and extending over the under parts, predominates on the extremities. The sides are of a dull pale, yellowish-brown. The ears are nearly naked during this season. The tail is white below, mixed above with gray and brown. This species is common in woody districts all over the continent of North America. It abounds on Mackenzie River as high as the sixty-eighth parallel ; but it appears to be replaced by the larger species both on the "Barren Grounds" to the eastward, and on the extensive plains through which the Missouri and Saskatchawan take their far-flowing courses. In summer it eats grass and other vegetables, and in winter willow-bark forms a principal part of its sustenance. It never burrows, and is much preyed on both by man and beast. The furs of this species are imported into Britain under the name of rabbit-skins. Twenty-five thousand have been taken at a trading-post in Hudson's Bay in a single season.

2d, The polar hare (Lepus glacialis, Leach). Dr. Leach appears to have first discriminated this species from the varying hare. It inhabits both sides of Baffin's Bay, and is common over the north-eastern districts of America. It 
is not known to advance southward beyond the fifty-eighth parallel, and does not occur in wooded countries. How. ever, it is often scen in the vicinity of thin clumps of sprucefir. It digs no burrow, but seeks the natural shelter of large stones. The winter-fur of this species is of a snowwhite hue, even to the roots. It is denser and of a finer quality than that of the preceding. Summer specimens killed in Melville Island (lat. $75^{\circ}$ ) had the hair of the back and sides of a grayish-brown colour towards the points. The weight of this species varies from seven to fourteen pounds. The flesh is whitish and excellent, being much suy erior in flavour to that of the American hare, and more juicy than the alpine hare of Scotland.

3d, The prairie hare (Lepus Virginianus, Harlan). The fur of this species is intermediate in fineness and density between that of the two speries just noticed. It is common on the north and south branches of the Saskatchawan, and on the plains of the Missouri, as well as on those of the Columbia River. It frequents open districts and clumps of wood, and its general habits resemble those of the European hare. This hare is pure white in winter, with the exception of the borders of the ears, which are of a wood-brown or fawn-colour. In summer, the head, neck, back, shoulders, and outer parts of the legs and thighs are of a lead-colour. The lower parts are white, with a tinge of lead-colour. In the month of March the summer-fur appears in combination with the spotless garb of winter, and is characteristic from the middle of April to the middle of November, after which the snowy dress again prevails. This species can leap twenty-one feet at a single spring. It weighs from seven to eleven pounds.

4th, The little chief hare (Lepus [Lagomys] princeps, Rich.). This is a small animal, of a blackish-brown colour above, and gray beneath. Its head is short and thick, and its ears are rounded. It inhabits the Rocky Mountains between the fiftieth and sixtieth degrees, and was killed by Mr. Drummond near the sources of the Elk River. The favourite localities of this species are heaps of loose stones, through the interstices of which it makes its way with great facility. It is often observed, towards sunset, mounted on a stone, and calling to its mates in a shrill whistle. It does not appear to excavate burrows, but when approached by the hunter it utters a feeble cry, resembling that of $\&$ 
rabbit in distress, and instantly disappears among the stones. This cry of fear is repeated by its neighbours, if it has any, and is so deceptive as to appear at a great distance, while in fact the creatures are close at hand. The little chief hare (so called, we understand, from its expressive Indian appellation, buckathrce $\left.k a h_{b}-y a w \approx c\right)$ bears a resemblance to the alpine pika described by Pallas and Pennant as inhabiting Kamtschatka and the Alenutian Islands. It is a diminutive animal, not measuring more than six or seven inches in length, and differs from the true hares in the number of its teeth. It also wants a tail.

The next group to which we have to call the attention of the reader is one of great interest, from the size, value, and general importance in the economy of nature, of the species by which it is constituted,-we mean the deer-tribe of America. Of these about half a dozen different kinds inhabit the fur-countries. As in the other numerous groups, we must here restrict ourselves to the history of a very few species.

The genus Cervus includes all those ruminating animals which are furnished with antlers. Two species are common to the northern parts of both continents; five or six belong to North America; four to America south of the equator; and above a dozen to India, China, and the archipelagoes of the south-east of Asia.* Of these some inhabit marshy forests, others the wooded shores of rivers or the sea, while others again prefer the bleak sides and barren valleys of mountain-districts. The species vary occasionally in colour, and are subject to those changes of constitution to which all animals are more or less liable, and which physiologists have distinguished by the names of albinism and mclanism,the first applied to the white, the second to the black varieties of colour. It has also been remarked as rather a singular circumstance, that the white varieties occur more frequently in the equatorial regions than in the colder countries of the north, - a proof, perhaps, that the intensity of light and

* For the natural history and description of many of the most remark. able of the Asiatic species, see "Historical and Descriptive Account of British India" (being Nos. XLVII, XLVIII, and XLIX. of the Family Library), vol. iii. 
heat are but secondary causes in the production of animal colours.*

The elk or moose-deer (Cervus alces) is a gigantic animal, of a heavy and rather disagreeable aspect. It is easily recognised by the great height of its limbs, the shortness of its neck, its lengthened head, projecting muzzle, and short up-

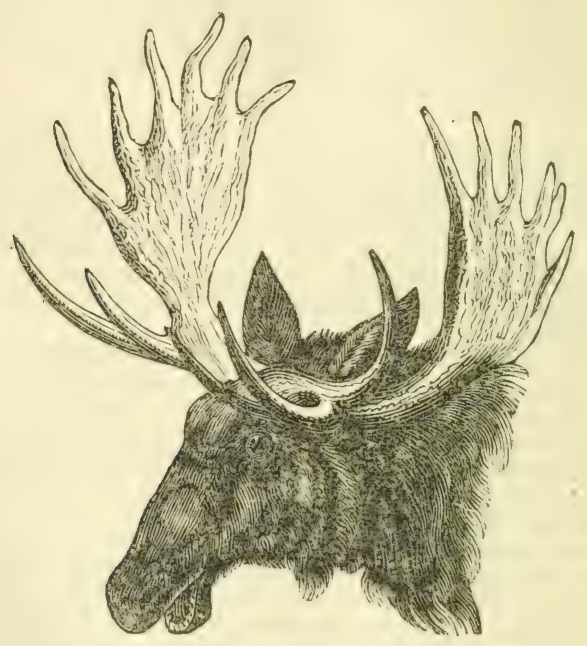

right mane. When full grown it measures above six feet in height. The fur is long, thick, and very coarse, of a hoary-brown colour, varying according to age and the season of the year. The antlers are very broad and solid, plain on the inner edge, but armed externally with numerous sharp points or shoots, which sometimes amount to twenty- 
eight. A single antler has been known to weigh fifty-six pounds.

The neck of the elk is much shorter than its head, which gives it almost a deformed appearance, though such a formation is in fact rendered necessary by the great weight of its antlers, which could not be so easily supported upon a neck of greater length. Notwithstanding the length of its muzzle, it collects its food with difficulty from the ground, being obliged either greatly to spread out or to bend its limbs. From this results its propens: ity to browse upon the tender twigs and leaves of trees, - a mode of feeding which the keepers of the French menagerie found it very difficult to alter in the individual under their charge. The upper part of the mouth is prolonged almost in the form of a $\mathrm{s}$.all trunk, and furnished with muscles, which give it great flexibility of movement, and enable it rapidly to collect its food. In summer, during the prevalence of the gadflies in the Scandinavian peninsula, it plunges into marshes, where it often lies day and night, with nothing above water but its head. It is even said to browse upon the aquatic plants beneath the surface, making at the same time a loud blowing sound through its nostrils.

The American elks live in small troops in swampy places. Their gait, according to Dr. Harlan, is generally a trot, and they are less active than most other deer. The old individuals lose their horns in January and February, and the young in April and May. In regard to their geographical distribution, they appear to have been formerly found as far south as the Ohio. At present they occur only in the more northern parts of the United States, and beyond the Great Lakes. Captain Franklin met with several during his last expedition, feeding on willows at the mouth of the Mackenzie, in lat. $69^{\circ}$. Although they are said to form small herds in Canada, yet in the more northern parts they are very solitary, more than one being seldom seen, except during the rutting-season, or when the female is accompanied by her fawns. The sense of hearing is remarkably acute in this species, and it is described as the shyest and most wary of the deer-tribe. It is an inoffensive animal, unless when irritated by a wound, when its great strength renders it formidable, or during rutting-time, when it will kill a dog or a wolf by a single blow of its fore-foot. It is much sought after by the American Indians, both on account of the flesh, 
which is palatable, and the hides, with which they in part manufacture their canoes, and several articles of dress. The grain of the flesh is coarse, and it is tougher than that of any other kind of venison. In its flavour it rather resembles beef. The nose is excellent, and so is the tongue, although the latter is by no means so fat and delicate as that of the reindeer. The male elk sometimes weighs from a thousand to twelve hundred pounds.

The reindeer (Cervus tarandus) is widely distributed over the northern parts of both the Old and New World. It has long been domesticated in Scandinavia, and is an animal of incalculable importance to the Laplander. We are less acquainted with the nature and attributes of the American species; but we shall here follow the prevailing opinion, and consider it identical with that of the north of Europe and of Asia. There appear to be two varieties of reindeer in the fur-countries. One of these is confined to the woody and more southern districts, the other retires to the woods only during the winter season, and passes the summer either in the Barren Grounds or along the shores of the Arctic Sea. Hearne's description applies to the latter kind, while the accounts given by the earlier French writers on Canada relate to the former.

The reindeer of the Barren Grounds is of small stature and so light of weight that a man may carry a full-grown doe across his shoulder. The bucks are of larger dimensions, and weigh, exclusive of the offal, from 90 to 130 pounds. The skin of the reindeer is light, and being closely covered with hair, it forms a suitable and highlyprized article of winter-apparel. "The skins of the young deer make the best dresses, and they should be killed for that purpose in the months of August or September, as after the latter date the hair becomes too long and brittle. The prime parts of eight or ten deer-skins make a complete suit of clothing for a grown person, which is so impervious to the cold, that with the addition of a blanket of the same material, any one so clothed may bivouac on the snow with safety, and even with comfort, in the most intense cold of an arctic winter's night."* Dr. Richardson is of opinion that the flavour of the reindeer flesh is superior to that of

- Fauna Boreali-Americana, vol. i. p. 242. 
the finest English mutton. However, the arimal must be in prime condition, as its lean state is comparatively worse than that of other creatures. Pemmican is formed by pouring one-third part of melted fat over the flesh of the reindeer after it is dried and pounded. Of all the deertribe of America this species is the most easily approached, and immense numbers are slaughtered for the use of the Indian families.

The other variety of reindeer to which we have alluded above is called the woodland caribou. It is much larger than that of the Barren Grounds, has smaller horns, and is greatly inferior as an article of diet. The most remarkable peculiarity in the habits of this animal is, that it travels to the southward in the spring. It crosses the Nelson and the Severn Rivers in vast herds during the month of May, and spends the summer on the low marshy shores of James's Bay, returning inland, and in a northerly direction, in September.*

Passing over the prong-horned antelope (A. furcifer, Smith), an inhabitant of the plains of the Missouri and Saskatchawan, remarkable for its extreme swiftness, we shall devote a few pages to the natural history of the wild sheep and goat of the Rocky Mountains, two of the most remarkable and important of the native quadrupeds of North America. (See the tollowing Plate.)

The Rocky Mountain sheep (Ovis montana, Desm. and Rich.) inhabits the range from which it derives its name, from its northern termination, or at least from latitude $68^{\circ}$, to the fortieth degree of north latitude. It also dwells among many of the elevated and craggy ridges which intersect the country lying to the westward, between the principal range and the shores of the Pacific Ocean; but it does not appear to have advanced beyond the eastern declivities of the Rocky Mountains, and it consequently does not occur in any of the hilly tracts nearer to Hudson's Bay. The favourite feeding-places of this species are "grassy knolls, skirted by craggy rocks, to which they can retreat when pursued by dogs or wolves." Its flesh, when in sea-

* For the history of the wapiti (C. strongyloceros), the black-tailed deer (C. macrotis, Say), and the long-tailed deer (C. leucurus, Douglas). we must refer to the writings of the various travellers and systemats authors nawned in the course of these chapters. 
son, is stated by Mr. Drummond to be quite delicious,-azbeing far superior to that of any of the deer-species, and even as exceeding in flavour the linest English mutton. This showy animal exceeds the Asiatic argali in size, and is much larger than the largest varieties of the domestic breeds. The horns of the male are very large. The ears are of moderate size. The facial line is straight, and the general form of the animal, being, as it were, intermediate between that of the sheep and stag, is not devoid of elegance. The hilir is like that of the reindeer, short, fine, and flexible, in its autumn growth; but as the winter advances, it becomes coarse, dry, and brittle, though still soft to the touch: it is necessarily erect at this season, from its extreme closeness. The limis are covered with shorter hairs. In regard to colours, the head, buttock, and posterior part of the abdomen are white; the rest of the body and the neck are of a pale or dusky wood-brown. A deeper and more lustrous brown prevails on the fore-part of the legs. The tail is dark-brown, and a narrow brown line, extending from its base, divides the buttock, and unites with the brown colour of the back. The colours reside in the ends of the hair, and as these are rubbed off during the progress of winter, the tints become paler.

The horns of the fernale are much smaller, and nearly erect, having but a slight curvature, and an inclination backwards and outwards. *

The folluwing are the dimensions of an old Rocky Mountain ram, killed on the south branch of the Mackenzie, and now in the Museum of the Zoological Society of London.

\begin{tabular}{|c|c|c|}
\hline & & Feet. \\
\hline Length of the head and body & & 6 \\
\hline Height at the fore shoulder & & 3 \\
\hline Length of tail ............. & .............. & 0 \\
\hline Length of horn, messured alc & ong the curvature & 2 \\
\hline Circumference of horn at its & base $\ldots \ldots \ldots \ldots \ldots$. & 1 \\
\hline Distance from tip to tip of th & le horns......... & 2 \\
\hline
\end{tabular}

These animals collect in locks consisting of from three to thirty, the young rams and the females herding together during the winter and spring, while the old rams form

* The Edinburgh College Museum containg a fine specimen of the Remale Rocky Mountain shoep. 

separate flocks, except during the month of December, which is their rutting-season. "The ewes bring forth lis June or July, and then retire with their lambs to the most. inaccessible heights. Mr. Drummond informs me, that ir the retired parts of the mountains, where the hunters had. seldom penetrated, he found no difficulty in approaching the Rocky Mountain sheep, which there exhibited the simplicity of character so remarkable in the domestic species; but that where they had been often fired at they were exceedingly wild, alarmed their companions on the approach of danger by a hissing noise, and scaled the rocks with a speed and agility that baflled pursuit. He lost several that he had mortally wounded, by their retiring to die among the secladed precipices."*

When the first mission was established in California, nearly two centuries after the discovery of that country, Fathers Piccolo and de Salvatierra found "two sorts of deer that we know nothing of; we call them sheep because they somewhat resemble ours in make. The first sort is as large as a calf of one or two years old; its head is much like that of a stag, and its horns, which are very large, are like those of a ram; its tail and hair are speckled, and shorter than a stay's, but its hoof is large, round, and cleft, as an ox's. I have eaten of these beasts; their flesh is very tender and delicious. The other sort of sheep, some of which are white, and others black, differ less from ours. They are larger, and have a great deal more wool, which is very good, and easy to be spun and wrought." $\dagger$ The animal first mentioned in the above quotation is the Rocky Mountain sheep; the other is the wild-goat of these same districts, of which we shall now exhibit a brief history. $\neq$

The Rocky Mountain goat inhabits the highest and least accessible summits. The precise limits of its territorial range have probably not yet been ascertained ; but it appears to extend from the fortieth to the sixty-fourth or sixty-fifth degree of north latitude. It is seldom or never observed

- Fauna Boreali-Americana, vol. i. p. 273.

$\uparrow$ Phil. Trans. No. 318 , p. 232.

+ I have elsewhere observed, that in the account of Lewis and Clarke's travels, in the Quarterly Review (vol. xii. p. 334, 362), there are two passages, which, if not corrected, would lead to an inaccurato conclusion regarding the origin of domestic sheep. See Quarterly Journal of Agriculture, No. ix. p. 374, Note. 
at any distance from the mountains, and is said to be less numerous on the eastern than the western sides. It was not met with by Mr. Drummond on the eastern declivities of the range, near the sources of the Elk River, where the sheep are numerous; but he learned from the Indians that it frequents the steepest precipices, and is much more diffieult to procure than the sheep. On the other hand, Major Long states, from the information of a factor of the Hudson's Bay Company, that they are of easy access to the hunter. The flesh of this species is hard and dry, and somewhat unsavoury, from its musky flavour. Beneath its long hairy covering there is a coating of wool of the finest quality. "If the Highland Suciety and the Hudson's Bay Company were to combine their resources of 'ways and means,' the importation of this fine animal into the alpine and insular districts of Scotland might be effected without much difficulty or any great expense."* The fine wool of this species grows principally on the back and buttock, and is intermixed with long coarse hair. $\dagger$

The bison, or American buffalo (Bos Americanus), is spread over a great portion of the temperate regions of America, and appears to extend southwards probably as far as the thirty-fifth degree of north latitude. Its characteristic positions, however, are the great prairies to the westward of the Mississippi, where, according to Dr. Harlan, they sometimes congregate in such vast troops that 10,000 individuals are supposed to have been seen at one time. Although they inhabited the Carolinas at the period of the earliest colonization, they have long since retired towards the plains of the Missouri. None have been seen in Pennsylvania for a long time, nor in Kentucky since about the year 1766. The influence exerted over the natural boundaries of the brute creation is indeed strikingly illustrated by the geographical history of this species. It appears to have formerly existed throughout the whole extent of the

* Edinburgh Review, No. 106, p. 353.

+ The synonymy of this animal is somewhat confused. It is the wool-bearing antelope, Antilope lanigera of Major Hamilton Smith; the mountain sheep (though distirict from the true Ovis montana) of Jameson and Ord; the Mazaria dorzata et sericea of Rafinesque; the Rupicapra Americana of De Blainville; the Antilope Americana of Desmarest; and the Capra Americana of Richardson. 
United States, with the possible exception of the territory to the east of Hudson's River and Lake Champlain, and of some narrow lines of coast along the Atlantic shores and the Gulf of Mexico. During the early part of the sixteenth century it was seen by Alvar Nunez near the Bay of St. Bernard, which may be regarded as its southern boundary on the eastern side of the Rocky Mountain chain. It extends much farther north among the central than the eastern territories; for we find that a bison was killed by Captain Franklin's expedition on the Salt River, in the sixtieth parallel; while it has not been traced to any of those tracts which lie to the northward of Lakes Ontario, Erie, \&c., and to the eastward of Lake Superior. Mr. Keating states that to the westward of Lake Winipeg the bison is found as far north as the sixty-second degree ; ${ }^{*}$ and Dr. Richardson adduces the testimony of the natives to show that they have taken possession of the flat limestone district of Slave Point, on the north side of Great Slave Lake, and have even wandered as far as the vicinity of Great Marten Lake, in latitude $63^{\circ}$ or $64^{\circ}$. The Rocky Mountain range appears to have formerly opposed a barrier to the westerly progression of the species; but they are said to have discovered of late years a passage across these mountains, near the sources of the Saskatchawan. They are now known to occur both in California and New Mexico, and their existence on the Columbia is also ascertained.

The male bisons contend together with great fury during the rutting-season, and it is dangerous to venture near them at that period. In general, however, they are shy and wary, and there is more difficulty than danger in approaching them; but when wounded they will sometimes turn upon and pursue the hunter. "While I resided at Carlton House," Dr. Richardson informs us, " an accident of this kind occurred. Mr. Finnan M'Donald, one of the Hudson's Bay Company's clerks, was descending the Saskatchawan in a boat; and one evening, having pitched his tent for the night, he went out in the dusk to look for game. It had become nearly dark when he fired at a bison-bull, which was galloping over a small eminence ; and as he was hastening forward to see if his shot had taken

* Account of Major Long's Expedition to the Source of St. Peter's River, vol. ii. chap. i. 
effect, the wounded beast made a rush at him. He had the presence of mind to seize the animal by the long hair on its forehead, as it struck him on the side with its horn; and being a remarkably tall and powerful man, a struggle ensued, which continued until his wrist was severely sprained, and his arm was rendered powerless; he then fell, and after receiving two or three blows became senseless. Shortly afterward he was found by his companions lying bathed in blood, being gored in several places; and the bison was couched beside him, apparently waiting to renew the attack had he shown any signs of life. Mr.

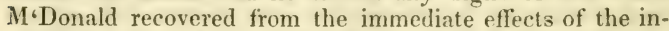
juries he received, but died a few months afterward." *

The flesh of a well-conditioned bison is juicy, and of excellent flavour. The tongue is a great delicacy, and may be so cured as to surpass the gusto of that part of an English cow. The hump, or $u i g$, as it is sometimes called, has a fine grain, and is almost as rich and tender as the tongue. In regard to the external characters of the bison, the male is remarkable for the enormous size of its head, the conical elevation between the shoulders, its small piercing eyes, short black horns, and on the fore-quarters the great profusion of shaggy hair. Its hind-quarters appear comparatively weak, from the shortness of the woolly hair by which they are covered. The male sometimes weighs above 2000 pounds ; but 12 or $14 \mathrm{cwt}$. is regarded as a good weight in the fur-countries. It measures eight feet and a half in length, and above six feet high at the fore-quarter. The cow is smaller in the head and shonlders than the bull.

According to Rafinesque, the bison has been domesticated in Kentucky and the Ohio.t It is even reported by some authors to have bred with the tame cow of European origin; and the cross breed is said to continue prolific. This statement, however, requires confirmation. "Our inquiries on the spot," says Major H. Smith, " never produced a proof, or even an assertion from the well-informed, that they had seen the hybrid oftspring." This animal is unknown to the Esquimaux on the shores of the Polar Sea.

* Fauna Boreali-Americana, vol. i. p. 281.

+ I state this on the information of M. Antoine Desmoulins, not baving had it.in my power to peruse the work of the writer above named. 
We shall conclude our account of the quadrupeds of North America with the description of the musk-ox (Onilos moschatus of De Blainville). We stand indebted for sur systematic knowledge of this curious animal to Pennant, who received a specimen of the skin from the traveller Hearne ; ${ }^{*}$ but it had been previously mentioned, after a vague fithion, by several of the early English voyagers, and M. Jerenie had imported a portion of the wool to France, from which stockings more beautiful than those of silk were manufactured. $t$ When full grown, this animal is about the size of the small Highland eattle. The horns are remarkably broad at their bases, and eover the brow and crown of the head, touching each other for their entire breadth from before backwards. The nose is blunt, and the head large and broad. The general colour of the coat is brown, and on the back there is a saddle-like mark of a brownishwhite colour. The hair is very long. The horns of the cow are smaller than those of the male, and do not touch each other at their bases, and the hair on the throat and chest is shorter.

The flesh of the musk-ox, in good condition, is well flavoured. It resembles that of the rein-deer, but is coarser grained, and smells strongly of musk. The carcass of this animal weighs, exclusive of the offal, about 300 pounds. The wool is remarkably fine. This species inhabits a great extent of burren land to the northward of the sixtieth parallel. They visit Melville Island (north lat. $75^{\circ}$ ) in the month of May, but they do not, like the rein-deer, extend to Greenland and Spitzbergen.

These are the principal quadrupeds of the northern regions of the New World. $\neq$

* Arctic Zoology, vol. i. p. 11.

† Voyage au Nord. Charlevoix, Histoire de la Nouvelle France.

₹ With a view to avoid repetition, we here omit the history of the seals and cetaceons tribes, as those departments have been pretty fully jllustrated in a former volume of this series. See No. XIV. of the Family Library, entitled "Narrative of Discovery and Adventure in the Polar Seas and Regions," by Sir John Leslie, Professor Jameson, and Hugh Murray, Esq. 


\section{CHAPTER VII.}

\section{The Birds of the Northern Regions of America.}

Turliey Buzzard-Golden-eagle-Bald-eagle-Hawks-Owls-Butcherbirils - King-bird - Northern Tyrant - Ameriean Water-ouzel-Redbreasted Thrush-Blue-bird-A retic Blue-bird-Cedar-bird, or American Chatterer-Snow-bunting - Painted Bunting - Pine-grosbeakEvening-grosbeak - Scarlet Tanager - Cuckoo-buntıng - Crows Woodpeckers - Humming-birds - Swallows - Belied Kingfisher Grouse-Passenger-pigeon-Grallatores - Natatores-Gulls-Rocky Mountain Golden-eye - Bewick's Swan - Trumpeter-swan - White Pelican-Great Northern Diver-Black-throated Diver-Guillemots.

THE difficulties attending the completion of an ornithological history were complained of by Buffon, and the chief of these was stated by that illustrious observer as consisting in the fact that naturalists were already acquainted with 800 species of the class; and he further expressed his opinion that there might actually exist 1500 or even 2000 different kinds of birds. Now, as nearly 6000 species of the feathered race have been ascertained up to the present period, and many new species are in the course of being discovered and described during every successive year, our readers may form some opinion of the laborious toil attending the researches of these "degenerate days," in which people of such inferior capacity to the French Pliny have to grapple with a subject so infinitely more encumbered. No doubt the division of labour has been more attended to since the greater extension of the field of exercise, and Buffon's brilliant genius was too often satisfied with vague generalities, unsupportable in proportion to the increase of that more definite knowledge which has been recently acquired. With an intellect so excitable and full of thought, and a flow of language so powerful and persuasive, it was no marvel that such a naturalist should have outstripped for a season all his competitors in the career of fame; but the fable of the helix and the hare is not altogether inapplicable to the two classes of observers, of one of which Bufton was the head and front; for there wats not only an oceasional 
pause in his onward progress, but those who now follow his footsteps in the search of truth are too often obliged either to retrograde or trace out a labyrinth with many windings. It is well, however, that such a master-spirit should in any way have embraced the subject of natural history; for it has too frequently happened that men of very steril genius, of whose mental constitution enthusiasm formed no portion, have imagined themselves devoted to the study. Now, even the obscurity and mistiness of Buffon, though perhaps not always equal to other people's sunshine, are yet composed of "clouds of glory," and hence the hold possessed by his writings, and by those of all belonging to the intellectual class of observers, to whom truth is as dear as it was to Aristotle, but to whom nevertheless the common sights of earth

\section{" do sometimes seem \\ Apparell'd in celestial light, \\ The glory and the freshness of a dream."}

The extension which we have given to the history of North American quadrupeds in the preceding chapter, and which we bestowed in consequence of the greater importance usually attached to the mammiferous class, renders necessary a more restricted selection in the other branches. We regret this the less in relation to the feathered tribes, as an admirable history of American birds has been lately brought within reach of every class of readers.* We shall, however, endeavour to exhibit a view of some of the more remarkable features of that department.

Among birds of prey, the eagle tribe naturally claim our first attention; but as it seems to be the practice of naturalists to give the vultures the precedence, we shall adhere to the usual course.

The turkey-vulture, or turkey-buzzard, as it is called in America (Cathartes aura), so common in the United States, occurs in the central districts of the fur-countries as far

* American Ornitbology, or the Natural History of the Birds of the United States. By Alexander Wilson and Charles Lucian Bonaparte; edited by Robert Jameson, Esq., F.R.S.E \& I., \&ce, four volumes. Edinburgh, 1831. In this edition (which forms volumes 78-81 of Constable's Miscellany) the subjects are systematically arranged for the first time, and many interesting additions have been inserted by the distiggaished editor. 
north as the fifty-fourth degree. It is partially migratory, even in the middle states, and retires southwards on the approach of winter. During their summer migration, a certain number of individuals reach the banks of the Saskatchawan, where they usually make their appearance when the month of June is far advanced, and after all the other summerhirds have arrived and settled in their leafy arbours. Though gregarious in the more southern parts of North America, where they roost together, and also both fly and feed in flocks, seldom more than a pair are seen in company towards their northern limits. They feed on carrion, which they discover at a great distance by the sense of sight alone; for it appears by recent observation that their sense of smell is extremely defective. They usually breed on the stump of a decayed tree, and have been observed to return to the same spot for a series of successive years. They are not only foul feeders, but sometimes gorge themselves so immoderately as to be incapable for some time afterward of taking wing. Mr. Ord has recorded that a man of Delaware, observing a group of turkey-buzzards regaling themselvesupon the putrid carcass of a horse, and having a mind to capture one of them, he cautiously approached the flock, and suddenly seized one of the fattest in his arms. The indignant vulture, however, immediately disgorged such a torrent of filth in his face, as to produce the effect of a powerful emetic, and cured him for ever after of all desire to catch any more turkey-buzzards.

The golden-eagle (Aquila chrysatos), of which the ringtail ( $F$. fulous) is regarded as the young, breeds among the sub-alpine recesses of the Rocky Mountains. The tailfeathers are highly valued by many tribes of American Indians for adorning their calumets or pipes of peace. The solitary habits of these birds, and the usually inaccessible nature of the vast precipices where they hang their " procreant cradles," prevent our acquiring much knowledge of the distinctive habits of the species, and hence our difficulty in diseriminating between the American and European kinds. Wilson observed the ring-tail sailing along the alpine declivities of the White Mountains of New-Hampshire, and over the Highlands of Hudson's River, and the adult bird, in the plumage of the goldeneagle, has also been observed in the United States. The 
vision of this bird is said to be so acute and long-sighted that it can discover its prey from a height at which it is itself scarcely visible, notwithstanding the breadth of its wide-expanded wings. "A story is current," says Dr. Richardson, "on the plains of the Saskatchawan, of a halfbreed Indian who was vaunting his prowess before a band of his countrymen, and wishing to impress them with a belief of his supernatural powers. In the midst of his harangue an eagle was observed suspended, as it were, in the air directly over his head, upon which, pointing aloft with his dagger, which glistened brightly in the sun, he called upon the royal bird to come down. To his own amazement, no less than to the consternation of the surrounding Indians, the eagle seemed to obey the charm, for instantly shooting down with the velocity of an arrow, it impaled itself on the point of his weapon !"*

A large and powerful species, more generally known in America, though not peculiar to the New $\mathrm{W}^{\top}$ orld, is the baldeagle (Aquila leucocephula). It resides all the year in the United States, but is a bird of passage in those more northern countries which lie between Great Slave Lake and Lake Superior. Fish form the favourite food of the bald-eagle, and there seems something more tyrannical in his mode of obtaining it than altogether accords with the equality of republican legislation. "Elevated," says Wilson, " on the high dead limb of some gigantic tree, that commands a wide view of the neighbouring shore and ocean, he seems calmly to contemplate the motions of the various feathered tribes that pursuc their busy avocations below. The snow-white gulls, slowly winnowing the air ; the busy tring $\propto$, coursing along the sands; trains of ducks, streaming over the surface; silent and watchful cranes, intent and wading; clamorous crows, and ull the winged multitudes that subsist by the bounty of this vast liquid magazine of nature : high over all these hovers one whose action instantly arrests

* Fauna Boreali-Americana, vol. ii., the Birds. By William Swainson, Esq., F.R.S.. F.L.S., \&c., and John Richardson, M.D., F.R.S., F.L.S., Surgeon and Naturalist to the Expeditions. London, 1831. This skilful and beautifully illustrated work is one of the most valuable volumes which has recently appeared on the subject of ornithology; and, viewed in connexion with the preceding publications of Wilson, C. I. Bonaparte, and Audubon, it goes far to complete our knowledge of the feathored tribes of the northern regions of the New World. 
all his attention. By his wide curvature of wing, and sudden suspension in the air, he knows him to be the fish-hawk, settling over some devoted victim of the deep. His eye kindles at the sight, and balancing himself, with half-opened wings, on the branch, he watches the result. Down, rapid as an arrow, from heaven descends the object of his attention; the roar of its wings, reaching the ear as it disappears in the deep, making the surges foam around! At this moment the eager looks of the eagle are all ardour, and levelling his neck for flight, he sees the fish-hawk once more emerge, struggling with his prey, and mounting in the air with screams of exultation. These are the signal for our hero, who, launching into the air, instantly gives chase, and soon gains on the fish-hawk; each exerts his utmost to mount above the other, displaying in these rencounters the most sublime aerial evolutions. The unencumbered eagls rapidly advances, and is just on the point of reaching his opponent, when, with a sudden scream, probably of despair and honest execration, the latter drops his fish; the eagle, poising himself for a moment, as if to take a more certain aim, descends like a whirlwind, snatches it in his grasp ere it reaches the water, and bears his ill-gotten booty silently away to the woods." *

Of the smaller tribes of the Falconida which inhabit the fur-countries, we shall satisfy ourselves by a simple enumeration of the names, $t$ and proceed to the nocturnal birds of prey.

Of the Strigida, or owls, Mr. Swainson has observed, "They present an assemblage of birds as united among themselves as they are distinct from all others. There is, we believe, no one species yet discovered which even a

* American Ornithology, vol. i. p. 23. We quote Professor Jameson's edition throughotit this volume.

$T$ The peregrine falcon ( $F$. peregrinus), the jerfalcon ( $F$. islandicus), the Ameriean sparrow-hawk ( F.sparverius), the pigeon-hawk ( $F$. columbarius), the merlin ( $F$. ocsulon), the goshawk ( $F$. palumbarius), the slate-coloured hawk (F. Pennsylvanicus), the common buzzard (F. butco), the red-talled or American buzzard ( $F$. borealis), the rough-legged falcon ( $F$. lagropus), the American ring-tail ( $F$. cyancus?). The preceding, with three species of eagle, raise the amount of northern accipitrinc diurnal birds to fourteen. C. I. Bonaparte enumerates seventeen species in his "Synopsis," and has described an eighteenth in his Supplement to Wilson, under the name of Falco Cooperi. Mr. Audubon has likevise 
common observer would not immediately pronounce to be an owl, or would be in danger of confounding with a hawk or goat-sucker, the only two groups to which the Strigida are related in immediate affinity. Yet, although this relationship is too obvious to be doubted, it must be confessed that a considerable hiatus intervenes between both. Whether these will be lessened by future discoveries, or whether owls, like the parrots, are in some degree an isolated group, whose aberrant forms no longer exist, are points which may always remain in obscurity."

The largest of the North American species is the great cinereous owl (Strix cincrea). It inhabits a vast extent of woody territory from Hudson's Bay to the Pacific. It is common along the shores of Great Bear Lake, and of course in these and other higher latitudes must of necessity pursue its prey by daylight, the mantle of night being there a thing unknown during the summer season. However, it hunts chiefly when the sun is low, and when the shadows of the great woods are deep and lengthened; for it is then that the American hares and many murine animais which form its favourite food are themselves abroad. On the $23 \mathrm{~d}$ of May, Dr. Richardson discovered a nest of the cinereous oivl, made of sticks and lined with feathers, on the top of a lofty balsam poplar-tree. It contained three young, covered over with a whitish down. He could only get the nest by felling the tree, which was a remarkably thick one; and while the operation was going on, the about to be bereaved parents flew in anxious and repeated circles above and around the objects of their long solicitude, keeping, however, so high in the air as to be beyond gunshot. The young were kept alive for a period of two months, after which they eflected their escape. This species measures about two feet in length from bill to tail.

The Virginian horned-owl (Strix Virginiana) is another large species peculiar to America, but very widely diffused

dedicated a new species, under the name of Fulco Stanleii, to the noble president of the Linnæan Society. Four of Bonaparte's list, viz. F. plumbeus, $F$. melanopterus, F. furcatus, and $F$. Pennsylvanicus, B., seem to occur only in the southern parts ni the United States, and therefore do not fall within our limits; but three others, the Stanley-hawk above named, along with Buteo Sancti-Johannis and B. hyemalis, are supposed to be northern birds. 'The aretic range of Mr. Audubon's species is probably still unkuown. 
sver the New World. It was killed by Mr. Drummond among the Rocky Mountains. It is known to inhabit the table-lands of Mexico, and even the species from the Straits of Magellan (Planches Enluminées, 585) appears to be identical. In the United States it is extremely common, and inhabits the fur-countries wherever the timber is of large size. Its loud nocturnal cries, issuing from the gloomiest recesses of the forest, are said to bear a resemblance to a hollow and sepulchral human voice, and have thus been the frequent source of alarm to the benighted traveller. A party of Scottish Highlanders, in the service of the Hudson's Bay Company, happened in a winter's journey to encamp after nightfall in a dense clump of trees, the dark tops of which, and their lofty stems, gave a solemnity to the scene, strongly excitable of superstitious feelings. The solemn effect was heightened by the discovery of a tomb, which, with a natural taste not unfrequently exhibited by the Indians, was placed in the centre of this secluded spot. The travellers had finished their evening repast, and were trimming their fire for the night, when for the first time the slow and dismal tones of the horned-owl fell on their ear. They at once concluded that a voice so mysterious and unearthly must be the moaning spirit of the departed, whose hallowed fane they had disturbed by inadvertently making a fire of the timber of his tomb. They consequently passed a long night of sleepless fear, and gladly quitted the ill-omened spot with the earliest dawn.*

In our notices of these and other well-known species, we consider it unnecessary to enter into any minute descriptive details of plumage, preferring rather to illustrate their history, distribution, and general modes of life, as more likely to interest the majority of readers. In the case, however, of any new or remarkable discovery, we may occasionally deviate from this rule, and, as an exception to our usual practice, we may here take an elegant species recently described for the first time under the name of the arctic or white-horned owl (Strix arctica). 'This fine owl is exceedingly rare, only a single specimen having been seen by the overland expeditions. It measures about two feet in length. Its general colour is white, tinged here and there with brown

* Fauna Boreali-Amerieana, vol. ii. p. 83. 
upon the dorsal aspect, and marked with crowded transverso blackish-brown bars and lines. The ground-colour of the under portion of the plumage is of a brilliant white, banded on the throat and flanks. The facial disk is imperfect, the ear-feathers are aniple, the tail rounded, the bill short and strong. This bird was killed at Carlton House, in the month of May.

We now enter upon a shoit consideration of the Insessorial or perching-birds, as they are called by the modern systematists. The order includes the Pica and Passeres of the Linnæan arrangement. We commence with the butcher-birds, genus Lanius.

The American gray-shrike (Lanius excubitorides of Swainson), a newly-ascertained species, bears a great resemblance to the ash-coloured shrike of Europe. It does not advance farther to the northward than the fifty-fourth degree, and secms to attain to that latitude only in the meridian of the warm and sandy plains of the Saskatchawan, which are stid to enjoy an earlier spring and longer summer than the densely-wooded countries between them and Hudson's Bay. It builds among willow-bushes, feeds on grasshoppers, and lays six eggs of a pale yellowish-gray, irregularly spotted with green and gray.

Allied to the shrikes in many particulars are the tyrant fly-catchers. The ling-bird (Tyrannus intrepidus) is one of the most remarkable for the buldness and reckless daring which he displays in his attacks on the largest of the feathered race. During the earlier months of summer, his life is one continued scenc of broil and battle. According to Wilson, hawks and crows, the bald-eagle, and the great black-eagle, all equally dread an encounter with this dauntless creature, who, as soon as he perceives a bird of prey, however powerful, in his neighbourhood, darts into the air, and quickly ascending above his supposed enemy, pounces with violence upon his back, and continues his attack till his own domains have been departed from. He is likewise obnoxious to the human race, on account of his love of bees; for he will take post on a fence or gitrden-tree in the vicinity of the hives, and make continual sallies on the industrious insects as they pass to or from their never-ending labours. The American ornithologist has given a poetical version of 
the life of this lively species, of which the following is the commencement :-

"Far in the south where vast Maragnon flows, And boundless forests unknown wilds enclose, Vine-tangled shores and suffocating woods, Parch'd up with heat, or drown'd with pouring floods,

Where each extreme alternately prevails,

And nature sad their ravages bewails;

Io! high in air above those trackless wastes ;

With spring's return the king-bird hither hastes ; Coasts the famed gulf, * and, from his height, explores

Its thousand streams, its long indented shores,

Its plains immense, wide opening on the day, Its lakes and isles, where feather'd millions play;

All tempt not him : till, gazing from on high,

Columbia's regions wide below him lie;

There end his wand'rings and his wish to roam,

There lie his native woods, his fields, his home;

Down, circling, he descends, from azure heights, And on a full-blown sassafras alights.

Fatigued and silent, for a while he views

His old frequented haunts, and shades recluse ;

Sees brothers, comrades, every hour arrive,--

Hears, humming round, the tenants of the hive.

Cove fires his breast ; he woos, and soon is blest,

1nd in the blooming orchard builds his nest."-

And so on. The king-bird migrates in summer at least as far north as the fifty-seventh parallel. It reaches Carlton House in the month of May, and retires southward in September. It feeds on insects and wild berries.

A new species of this genus has been lately described under the title of northern tyrant (Tyranmis borcalis, Swainson). It was shot on the banks of the Saskatchawan, but nothing is known of its habits. It is considerably smaller than the preceding, and may at once be distinguished from it by its forked tail, not tipped with white.

Among the Merulidae or thrushes we may here mention the representative of our water-ouzel, the American dipper (Cinclus Americanus). Although ascertained by Mr. W. Bullock to be an inhabitant of Mexico, and obtained by Mr. Drummond on the eastern declivity of the Rocky Mountains, near the sources of the Athabasca River, it does not yet appear to have been detected in the intermediate regions of 
the United States. According to Bonaparte, this species measures eight inches and a half. It is consequently longer than the European dipper or water-crow. The general plumage is dark-grayish slate-colour. The legs and feet are flesh-colour. We as yet know nothing of the habits of the American species, but its European congener dwelis single or in pairs by the side of clear and swiftrunning streams. It walks under water in search of prey, wading in from the shore, and remaining for some time submerged.*

The bird called robin in America is the red-breasted thrush of Pennant (Turdus migratorius). It is one of their best known and earliest songsters. While the fields are yet dappled with snow, they are seen in flocks, and some few lively aspirants will even then mount to the top of a post, and make attempts at song. As the season advances their notes are universally heard, and as universally beloved, and are regarded as the "prelusive symphony" to the great concert which is about to burst ere long from numerous bills, from every thicket, wood, and field. Although regarded with much of the same feeling as that which we ourselves entertain towards our own household bird, the redbreast, they are, nevertheless, brought to market in great numbers, and Wilson mentions that in the month of January, 1807, two young men shot thirty dozen in a single excursion. This species inhabits the whole of North America from Hudson's Bay to Nootka Sound, and as far south as Georgia, though they are said rarely to breed on this side the mountains farther south than Virginia. "Within the Arctic Circle," Dr. Richardson has beautifully observed, "the woods are silent in the bright light of noonday ; but towards midnight, when the sun travels near the horizun, and the shades of the forest are lengthened, the concert commences, and continues till six or seven in the morning. Even in those remote regions the mistake of

* While engaged in the correction of these sheets for the press, we have been favoured by Sir William Jardine with a copy of his yet unpublished edition of Wilson's American Ornithology. Many valuable notes have been appended by the editor to illustrate the general distribution of those groups, of which there are Ameriean representatives. The supplementary volumes by C. L. Bonaparte are included; and most of the new species discovered or described by Messrs. Swainson, Richardcon, and Audubon, are likewise inserted or referred to. 
those naturalists who have asserted that the feathered tribes of America are void of harmony might be fully disproved. Indeed, the transition is so sudden from the perfect repose, the deathlike silence of an Arctic winter, to the animated bustle of summer; the trees spread their foliage with such magical rapidity, and every succeeding morning opens with such agreeable accessions of feathered songsters to swell the chorus-their plumage as gay and unimpaired as when they enlivened the deep rreen forests of tropical climesthat the return of a northern spring excites in the mind a deep feeling of the beauties of the season, a sense of the bounty and providence of the Supreme Being, which is cheaply purchased by the tedium of nine months of winter. The most verdant lawns and cultivated glades of Europe, the most beautiful productions of art, fail in producing that exhilaration and joyous bunyancy of mind which we have experienced in treading the wilds of Arctic America, when their snowy covering has been just replaced by an infant but vigorous vegetation. It is impossible for the traveller to refrain, at such moments, from joining his aspirations to the song which every creature around is pouring forth to the Great Creator." This is finely said, and loses none of its force as proceeding from the pen of one not given to affect a sickly sentimentalism, but who has ever had to do more with the practice than the poetry of life and nature. In a sinilar strain so also wrote the divine Milton,-but to whom the freshness of spring, the azured mantle of the glorious summer, and the varied splendour of the farspreading autumnal forests, were then only as visions of the past-

\section{"So thick a drop serene}

Had quench'd his orbs, or dim suffusion veil'd." .

Of many beautiful and interesting species of the family of the Sylvialce which enliven the countries of our present inquiry, we shall confine our observations to the blue-birds.

The common blue-bird (Saxicola sialis, Bon., Erythaca Wilsonii, Swain.) has the whole of the upper plumage of a fine blue, while the throat, neck, breast, and flanks are bright orange-brown. The general character and movements of this bird resemble those of the European red- 
breast, and he is himself as familiarly known in summer to the children of America, as the robin is to ourselves in the winter season. Wilson informs us that the society of the blue-bird is much courted by the inhabitants of the country, and that few farmers neglect to provide for him a snug little summer-house, ready fitted and rent-free. $\mathrm{He}$ is migratory over the northern districts, but a few remain throughout the winter in some parts of the United States.

A newly-discovered species, nearly allied to the preceding, is named by Mr. Swainson the Arctic blue-bird (Erythaca Arctica). Its colour is a fine ultramarine blue above, beneath greenish-blue, and whitish on the lower part of the abdomen and under tail-coverts. The only specimen procured by the overland expedition was shot at Fort Franklin in July, 1825. It is merely a summer visiter of the furcountries, and no knowledge of its haunts or habits has been yet obtained.

To illustrate the Ampelide we shall merely mention the American cedar-bird, or chatterer of Carolina, as it was called by Edivards (Bombycilla Americana). This bird was regarded by the naturalists of last century as a mere variety of the European or Bohemian chatterer. It is, however, a distinct species, of smaller size, and has no white upon the wings; the chin has less black, and the bill is shorter and somewhat broader. The European bird has also been detected in North America by Mr. Drummond and Dr. Richardson.

The well-known snow-bunting (Emberiza nivalis) is common to the New and Old World. "Near the large grave," says Captain Lyon, "was a third pile of stones covering the body of a child which was coiled up in the same manner. A snow-bunting had found its way through the loose stones which composed this little tomb, and its now forsaken, neatly built nest, was found placed on the neck of the child. As the snow-bunting has all the domestic virtues of our English redbrea'st, it has always been considered by us as the robin of these dreary wilds, and its lively chirp and fearless confidence have rendered it respected by the most hungry sportsman. I could not on this occasion view its little nest placed on the breast of infancy, without wishing that I possessed the power of poetically expressing the 
feelings it excited." " The bold navigator may rest assured that his simple recital of this circunistance is much more effective and pictorial than if he had recourse to a rhyming dietionary. The Laplana bunting (E. Lapponica) is also found in the northern rerions of both continents; and $a$ beautiful species, nearly allicd to it, the painted bunting (Plectropkanespicta of Swainson), was lately discovered on the banks of the Saskatchawarı. For the history and description of these, as well as of many beautiful larks and finches, we must refer the reader to the works already mentioned.

The pine-grosbeak (Pyrrhula enucleator) is the largest of the bullfinch tribe. It measures above eleven inches in length. Of the grosbeaks, properly so called (genus Coccothraustes), the gayest and most remarkable is called the evening-grosbeak ( $C$. vespertina, Bon.). It is a common inhabitant of the maple-rroves which adorn the plains of the Saskatchawan, and is known to the natives by the name of secsebusquit-pethaysish, which, being interpreted, signifies sugar-bird. According to Mr. Swainson's views, this is the only genuine species of the genus hitherto discovered in America. We owe it to the observance of Mr. Cooper.t

The scarlet tanager (Tanagra rubra) is one of the most brilliant of those southern species which during the summer migration shed their lustre over more northern lands. The whole plumage, with the exeeption of the wings and tail, is of the most vivid carmine-red. The wing-coverts, posterior secondaries, and middle tail-feathers are black, and form a rich contrast to the other portions of the plumage. After the antumnal moult, the male becomes dappled with greenish-yellow. The plumage of the female is green above and yellow below; her wings and tail are brownish-black, edged with green. Though this species sometimes builds in orchards, and visits the cherry-trees for the sake of their fruit, it does not frequently approach the habitations of man, but prefers the solitude of the umbrageous woods. In addition to fruits, its food consists of large winged insects, such as wasps, hornets, and humblebees. The scarlet tanager is as yet unknown heyond the forty-ninth parallel, and so comes just within the southern limits of the fur-

* Narrative of an A ttempt to reach Repulse Bay.

$\uparrow$ Ann. Lyc. New York, vol. i. p. 220. 
countries. The following interesting narrative is given by Alexander Wilson:- "Passing through an orchard one morning, I caught one of these young birds, that had but lately left the nest. I carried it with me about half a mile, to show it to my friend Mr. William Bartram; and having procured a cage, hung it up on one of the large pinetrees in the hotanic garden, within a few feet of the nest of an orchard-oriole, which also contained young, hopeful that the charity or tenderness of the orioles would induce them to supply the cravings of the stranger. But charity with them, as with too many of the human race, began and ended at home. 'The poor orphan was altogether neglected, notwithstanding its plaintive cries; and as it refused to be fed by me, I was about to return it back to the place where I found it, when, towards the afternoon, a scarlet tanager, no doubt its own parent, was seen fluttering round the cage endeavouring to get in. Finding this impracticable, he flew off and soon returned with food in his bill, and continued to feed it till after sunset, taking up his lodgings in the higher branches of the same tree. In the morning, almost as soon as day broke, he was again seen most actively engaged in the same affectionate manner ; and, notwithstanding the insolence of the orioles, continued his benevolent offices the whole day, roosting at night as before. On the third or fourth day he appeared extremely solicitous for the liberation of his charge, using every expression of distressful anxiety, and every call and invitation that nature had put in his power for him to come out. This was too much for the feelings of my venerable friend; he procured a ladder, and, mounting to the spot where the bird was suspended, opened the cage, took out the prisoner, and restored him to liberty and to his parent, who, with notes of great exultation, accompanied his flight to the woods. The happiness of my good friend was scarcely less complete, and showed itself in his benevolent countenance; and I could not refrair saying to myself-if such sweet sensations can be derived from a simple circumstance of this kind, how exquisite, how unspeakably rapturous, must the delight of those individuals nave been, who have rescued their fellow-beings from death' chains, and imprisonment, and restored them to the arms of their friends and relations! Surely in such godlike actions 
virtue is its own most abundant reward !"* Nevertheless, as practical ornithology can by no means flourish without powder and shot, Wilson continued to knock down as many birds as he required,-and they were many,-for the space of several succeeding years. Alas! that the latter were so few.

More allied to the starling tribe is a bird remarkable for the singularity of its habits, called the cowpen or cuckoobunting (Emberiza pecoris of Wilson), classed by $\mathrm{Mr}$. Swainson in the genus Molothrus. It visits the fur-countries in May, and, after ranging as far north as the sixtieth parallel, it departs in September, and collecting in large flocks during the ensuing month in Pennsylvania, it finally retires to winter-quarters in Mexico and the most southern parts of the United States. It feeds on grain, grass, and worms, and is frequently seen perched familiarly on the backs of cattle. But the most remarkable trait in the character of this species is its practice (like that of our own cuckoo) of laying its eggs in the nests of other birds, and abandoning its future offspring to the care of strangers. The yellow-throat and red-eyed fly-catcher are most frequently selected to perform the office of foster-parents.

Passing over the rice-bird, the Baltimore oriole, the purple grakle, and others of the Sturnidce, we shall here briefly notice the family of the crows. The raven (Corvus corax, ) which occurs in all the four quarters of the globe, is abundant in the fur-countries; and the carrion-crow ( $C$. corone) also occurs there, but appears to be of a less hardy nature, as it is seen in the interior in summer only, and does not seem to approach within 500 or 600 miles of Hudson's Bay. The magpie ( $C$. pica) is as common in the prairie lands of America as it is in Europe. Several beautiful jays likewise occur in North America.

We come next to the woodpeckers, which are numerous and widely spread over the American continent, as might be expected in connexion with the vast forests with which so much of the country is still encumbered. The ivory-billed

* American Ornithology, vol. ii. p. 230. 
woodpecker (Prcus principalis) is undoubtedly the most magnificent of the genus. While many of the sinaller kinds seek their prey in the orchard or shrubbery, among rails, fences, or prostrate logs, the present species inhabit the most towering trees of the forest, "seeming particularly attached to those prodigious cypress swamps, whose crowded giant sons stretch their bare and blasted, or moss-hung arms, midway to the skies. In these almost inaccessible recesses, anid ruinous piles of impending timber, his trumpet-like notes and loud strokes resound through the solitary savage wilds, of which he seems the sole lord and master." The food of this species, Mr. Audubon informs us, consists chiefly of beetles, larvæ, and large grubs. No sooner, however, are the grapes of the forest ripened, than they are eaten by the ivory-billed woodpecker with great avidity. "I have seen this bird," says the last-named excellent observer, "hang by its claws to the vines, in the position so often assumed by a titmouse, and, reaching downwards, help itself to a bunch of grapes with much apparent pleasure."* Although we have introduced a notice of this fine species, we are not aware that it extends so far to the north as the countries with which we are at present engaged. It is, however, well known in many of the United States. A much more northern species is the three-toed woodpecker ( $P$. tridaciylus of Swainson), which exists in all the forests of spruce-fir that lie between Lake Superior and the Arctic Sea. It is the most common of the species that occur to the north of Great Slave Lakc.

The varieties of the feathered race are inexhaustible, Each tribe and family contains many familiar and well-remembered species, on the history of which we could dilate with pleasure; but we must of necessity leave even the names of many unrecorded. Two frail and fairy beings, however, seemingly of too delicate a fabric to withstand the rudeness of the northern blasts, now solicit our regard, and as they have flown far to obtain it, we must here insert \& compendious history of the North American humming-birds. Meanwhile, let us borrow the words of the enthusiastic Audubon. They apply to the ruby-throated species (Trow

* Ornithological Biography, vol. i. p. 344 $\mathrm{B}$ b 
chilus colubris, Linn.). " No sooner has the returning sun again introduced the vernal season, and caused millions of plants to expand their leaves and blossoms to his genial beams, than the little humming-bird is seen advancing on fairy-wings, carefully visiting every opening flower-cup, and like a curious florist, removing from each the injurious insects that otherwise would, ere long, cause their beauteous petals to droop and decay. Poised in the air, it is observed peeping cautiously and with sparkling eye into their innermost recesses, while the ethereal motions of its pinions, so rapid and so light, appear to fan and cool the flower without injuring its fragile texture, and produce a delightful murmuring sound, well adapted for lulling the insects to repose. Then is the moment for the humming-bird to secure them. Its long delicate bill enters the cup of the flower, and the protruded double-tubed tongue, delicately sensible, and imbued with a glutinous saliva, touches each insect in succession, and draws it from its lurking-place to be instantly swallowed. All this is done in a moment, and the bird, as it leaves the flower, sips so small a portion of its liquid honey, that the theft, we may suppose, is looked upon with a grateful feeling by the flower, which is thus kindly relieved from the attacks of her destroyers.

"The prairies, the orchards, and gardens, nay, the deepest shades of the forest, are all visited in their turn, and everywhere the little bird meets with pleasure and with food. Its gorgeous throat in beauty and brilliancy baffles all competition. Now it glows with a fiery hue, and again it is changed to the deepest velvety black. The upper parts of its delicate body are of resplendent changing green, and it throws itself through the air with a swiftness and vivacity hardly conceivable. It moves from one flower to another like a gleam of light, upwards, downwards, to the right, and to the left. In this manner it searches the extreme northern portions of our country, following with great precaution the advances of the season, and retreats with equal care at the approach of autumn."**

The nest of this species is formed with a delicacy proportioned to its tiny inmates. The external parts consist of a light-gray lichen found on the branches of trees or on

- Ornithological Biography, vol. 1. p. 248. 
decayed fence-rails, and so trimly arranged around the nest, as well as at some distance from the spot to which it is attached, as to appear like a portion of the stem. These little pieces of lichen are glued together, as some say, with the saliva of the bird. The next layer consists of a cottony substance, and the innermost of silky fibres obtained from various plants, but all extremely soft and delicate. In this sweet receptacle the female deposites a single pair of eggs, pure white, and of an almost oval form.

A Virginian gentleman kept two of these creatures in a cage for several months. He supplied them with a mixture of honey and water. On this they appeared to feed; but as the sweet and viseous liquid brought many small flies about the cage, the humming-birds were seen to snap at and swallow the insects with great eagerness. Mr. C. W. Peale also succeeded in rearing two young ones from the nest. They used to fly about the room, and would frequently perch on Mrs. Peale's shoulder. Wilson himself took a nest in the summer of 1803 , the inhabitants of which were just about to fly ; indeed one of them flew out by the window that same evening, and, striking against a wall, was killed. The other refused food, and was scarcely alive next morning. A lady, however, undertook to nurse it, and dissolving a little sugar in her mouth, she thrust in the bird's bill, which immediately sucked with great avidity. It was kept for three months, and daily supplied with loafsugar dissolved ir water. Fresh flowers were also scattered every morning around its food ; and in this way it appeared gay, active, and full of spirits, and hovered from flower to flower as if in its natural state. It never failed to express, both by a peculiar motion and a chirping voice, the greatest pleasure when its supply of flowers was introduced into the cage. It became the admiration of all beholders, and sanguine hopes were entertained that it might be preserved throughout the winter; but unfortunately it one day got at large, and flying about the room in a more excited manner than usual, it injured itself in such a way as to die soon after.* The species to which these observations apply

* In addition to the writings of Wilson and Audubon, consult, for a knowledge of the history and habits of humming-birds, Mr. Bullock's "Six Months in Mexico," and M. Lesson's "Histoire Jes Oiseur. biouches." 
ranges during the summer season as far to the north as the 57th parallel. Dr. Richardson found it on the plains of the Saskatchawan, and Mr. Drummond discovered its nest near the sources of the Elk River. 'This was composed chiefly of the down of an anemone, bound tegether by a few stalks of moss and bits of lichen, and had an internal diameter of one inch.

The other species to which we alluded above was first observed by our illustrious navigator Cook, on the barren shores of Nootka Sound. It is the ruff-necked hummingbird (Trochilus collaris of Latham, and the Trochilus rufus of Gmelin). It is a superb species, and ranges to the southward at least as far as the table-land of Mexico, near Real del Monte; from which locality specimens are preserved in the unrivalled collection of Mr. Loddiges. It was traced by Kotzebue along the Pacific shores as far as the sixty-first parallel. The migration of birds has in every age afforded a subject of pleasing speculation to the admirers of the never-ending wonders of the natural world; but in no instance does it more freely excite our admiration than when manifested by creatures so frail, and fantastically attired in hues

"Which make the rose's blush of beauty pale, And dim the rich geranium's scarlet blaze."

Of the long-winged and most aerial of the feathered race, the swallow tribe, many beautiful species inhabit America. We shall here notice only the white-fronted or cliff-swallow (Hirundo lunifrons of Say), discovered near the Rocky Mountains by Major Long. It was seen in great numbers by Sir John Franklin's party in 1820, while travelling from Cumberland House to Fort Enterprise. Its clustered nests are frequent on the fices of the rocky cliffs of the Barren Grounds, and a number of them made their first appearance at Fort Chipewyan on the 25th of June, 1825, and immediately built their nests under the eaves of the dwelling-house, which are not more than six feet above a balcony that extended the whole length of the building, and was a constant promenade. "They had thus to graze the heads of the passengers on entering their nests, and were moreover exposed to the curiosity and depredations of the children, to whom they were novelties : yet they preferred 
the dwelling-house to the more lofty eaves of the storehouses, and in the following season returned with augmented numbers to the same spot. Fort Chipewyan has existed for many years, and trading-posts, though far distant from each other, have been established in the fur-coun. tries for a century and a half; yet this, as far as I could learn, is the first instance of this species of swallow placing itself under the protection of man within the widely-extended lands north of the Great Lakes.* What cause could have thus suddenly called into action that confidence in the human race with which the Framer of the Universe has endowed this species, in common with others of the swallow tribe?" + This species is very widely distributed. It was transmitted to Professor Jameson from India some years ago by the Marchioness of Hastings.

Passing over the goat-suckers (genus Caprimulgus), which are frequent and numerous in the northern regions of America, we may here record the name of the belted king-fisher (Alcedo alcyon, Linn.) as the sole representative in the fur-countries of a tribe very widely diffused over all the known regions of the earth. It is a bird of passage, and winters as far south as the West Indies, although it also occurs in Georgia and the Floridas during that season.

A more numerous and much more important family of birds (in America) are the Tetraonida or grouse. Nearly a dozen species inhabit the fur-countries, and of these the largest and most remarkable is the pheasant-tailed grouse or cock of the plains (Tetrao urophasianus, Bon.). The flight of this bird, Mr. Douglas informs us, is slow and unsteady, and affords but little amusement to the sportsman. Its wings are small, and but feebly feathered in proportion to the size of the bird, which measures from thirty-two to thirty-four inches in length, and weighs from six to eight pounds. Though it may be said to represent the capercailzie

* The late governor, De Witt Clinton, has given a very interesting history of the closely-resembling species, $H$. fulva, which about sixteen years ago began to build its nests on the wails of houses in the Western States, and has every succeeding summer been advancing farther to the .eastward. Vide Ann. Lyc., New-York, vol. i. p. 156.

+. Faun 2 Boreali-Americana, vol. ii. p. 331 .

- B b 2 
or wood-grouse ( $T$. urogallus) in the New World, it differs in this respect, that it never perehes. Its flesh is darkcoloured, and not particularly good in point of flavour.*

We shall close our account of American land-birds, commonly so called, by a reference to the passeriger-pigeon (Columba migratoria). It may be presumed to be sufficiently common in America, from a fact, or rather a calculation, given by Alexander Wilson. He estimated a flock which continued to pass above him for the greater part of a day to have been a mile in breadth and 240 miles in length, and to have contained (three birds being assigned to every square yard) at least two thousand two hundred and thirty millions, two hundred and seventy-two thousand pigeons !t Mr. Audubon contirms his predecessor's account by a narrative still more extraordinary, $\ddagger$ and adds, that as every pigeon consumes fully half a pint of food (chiefly mast), the quantity necessary for supplying his flock must have amounted to eight millions seven hundred and twelve thousand bushels per day :-an expensive doocot.

Of the order of waders (Grallutores) none winter in the fur-countries. They generally arrive about the end of April and berinning of May, and are driven southwards in autumn by the advance of winter, and its hardening influcuce upon the moist grounds and swampy shores, from which these long-legged gentry draw their principal support. We shall rest satisfied by furnishing a list of their names in the note below. $\oint$

* For the history and description of the other American grouse, consult Mr. David Douglas's paper in the 16th volume of the Linn. Trans.; Professor Jamesun's edition of the American Ornithology, vol. ii. p. 314, and vol. iv. 1). 1S9, 325; the second volume of the Fauna Boreali-Americaua, p. 312; and my own "Illustrations of Zoology," vol. i. plates 26, $27,30,31$, and corresponding letter-press.

† See vol. ii. p. 299.

+ siee his interesting histnry of the passenger-pigeon in the first volume of the "Ornirholorical Biography," p. 319-326.

(f) The sauderling (Calu'ris arenaria, Illiger); American ringplover (Charadrims semipalmatus, Bonap.); kildeer-jlover (Ch. vociferus, I.inn.); golden-plover (Ch. plunialis, Linn.?); gray lapwing ( Vanellus melanogaster, Bechst.); turnstone (Strepsilus interpres, III.); whooping-crane (Grus Americana, Temm.); brown crane (G. Canadensis, Temm.); creat heron (A:rea Herodias, Linn.); American bittern, (Ardca lenugrinosu, Mont.); American avoset (Renurvirnstra Amerr 
Of the stiil more extensive order of Natatores, or webfooted swimming-birds (Pulmipedes), we shall present only a few brief notices. Birds of this order are fully more remarkable for the texture than the tints of their plumage, although several species of the duck tribe are likewise distinguished by considerable brilliancy of colour. Destined to inhabit the seashore, and the banks of lakes and rivers, they are much exposed to the inclemencies of the weather, and their feathers are providentially rendered very close and compact, and abundantly imbued with an oily secretion, through which they become impermeable by moisture. This beautiful provision, as I have elsewhere observed, ${ }^{*}$ is more indispensable to the economy of the Palmipedes than to any other order, as many of them are strictly oceanic, being sometimes found 500 leagues from land, and consequently having no other place of repose, either by night or by day, than the surface of the "injurious sea." In aduition to an abundant plumage, the truly aquatic kinds, such as ducks and divers, are furnished with a close, and, in some instances, very valuable down, which preserves them from the effects of cold and moisture, and is afterward used in the formation of their nests on the arrival of the genial season. With the exception of ducks and mergansers, no very marked distinction prevails between the plumage of the

rana, Linn.); long-hilled curiew (Numenius longirostris, Wils.); Hudsonian curlew (N. Hudsonicus, I.ath.); Esquimaux curlew ( $N$. borealis, Lath.); Douglas' sandpiper (T'rnga Douglasii, Swains.), a new species not uncommon in the fur countries as high as the sixtieth parallel; slendershanks sandpiper ( $T$. himantopus, Bonap.?); semipalmated sandpiper ( $T$. scmipalmatr, Wils.); purple sandpiper ( $\boldsymbol{T}$. maritima, Brunn.); dunlin ( $T$. alpina, Penn.); Schintz's sandpiper ( $\boldsymbol{T}$. Schinzii, Brehm.); pigmy sandpiper (T. minuta, Leisler); diminutive sandpiper ( $T$. msilla, WVils.); knot ( $T$. cincrea, Linn.); semipalmated tatler (Totanus semipalmatus, Temm.); tell-tale (T. vociferus, Sabine); yellow-shanks tatler ( $T$. flaripes, Vieillot); red-shank or gambet ( $T$. calidris, Bechst.); Bartram's tatler (T. Bartramius, Temm.); whitetailed tatler ( $T$. ochropus. 'Temm.); green-rump tatler ( $T$. chloropygius, Vieill.); great-marbled godwit (Limosa fedoa, Vieill.); Hudsonian godwit ( $L$. Hudsonuca, Swains.); New-York godwit (Scolopax Novoboracensis, Wils.); Drummond's snipe (Sc. Drummondii, Swains.); Wilson's snipe (Sc. Wilsonii, Temm.); yellow-breasted rail (Rallus Novoboracensis, Bonap.); Carolina rail (R. Carolimus, Bonap.); American coot (Fulica Americana, Gmel.); Wilson's phalarope (Ph. Wilsonii, Sab.); hyperborean phalarope (Ph. hyperboreus, Lath.); flat-billed phalarope (Ph. fulicarius, Bonap.).

* Illustrations of Zoology, i el. A., introductory letter-press to plato 3. 
sexes. The young differ considerably from the adults, and seldom attain the perfect plumage till the lapse of one or two seasons.

North America produces several grebes (genus Podiceps) and sea-swallows (Sterna). About a dozen different kinds of gull (Larus) inhabit both the barren shores and inland swamps of the fur-countries. A beautiful species called the fork-tailed gull (Larus Sabinii) is here represented.

This bird was discovered by Captain Edward Sabine on a group of three low rocky islands, about twenty miles from the mainland, off the west coast of Greenland. "They flew with impetuosity towards persons approaching their nests and young; and when one bird of a pair was killed, its mate, though separately fired at, continued on wing close to the spot where it lay."* The fork-tailed or Sabine gull is one of the most elegant of the genus. Its colours, though sufficiently contrasted for variety and liveliness of effect, are finely harmonized. The colour of the head assumes a considerable variety of appearances, according to the direction and degree of light in which it is examined; - a tinge of black, brown, blue, or purple, seeming aiternately suffused over the deep lead colour which forms the prevailing tone by which the parts are usually characterized. There appears to be no difference in the plumage of the sexes, but the female is rather less in size. A solitary example of this species was met in Prince Regent's Inlet during Sir Edward Parry's first voyage, and in the course of the second voyage many were obtained on Melville Peninsula. They arrive in high northern latitudes in June, and take their departure southwards as early as the month of August.

As an example of the northern ducks, we shall confine ourselves to the Rocky Mountain golden-eye (Clangula Barrovi, Rich. and Swains.), a species distinguished from our common golden-eye by the head and upper portion of the neck being of a pansy-purple colour, with a large crescentshaped spot of white before each eye. The white speculum of the wing is separated from a band of the same colour on the coverts by a black stripe. It is dedicated to Mr. Barrow of the Admiralty, our chief promoter of those important 


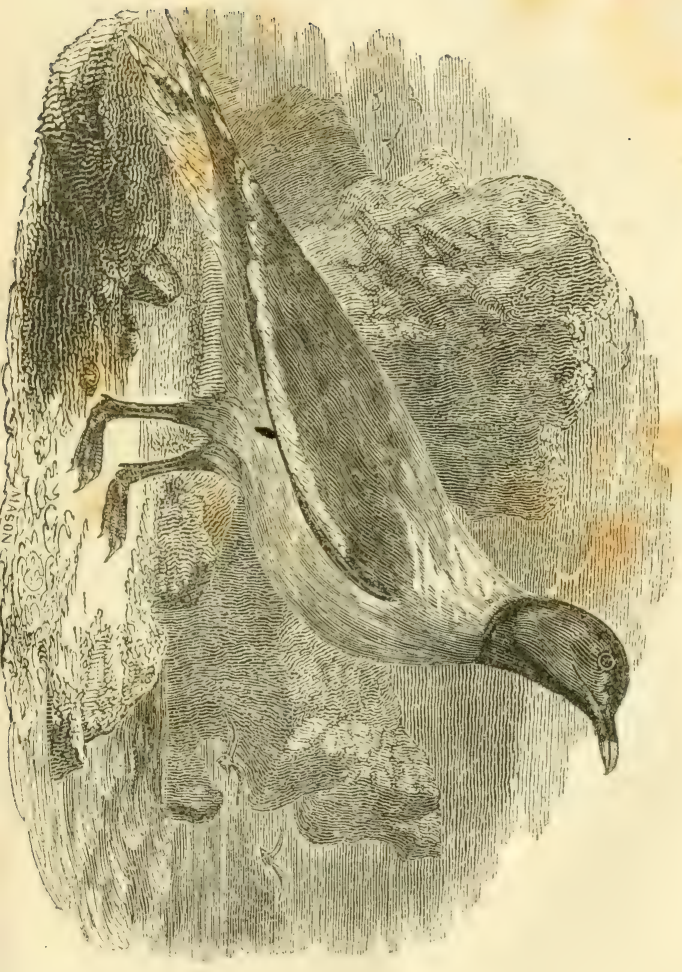



geographical discoveries, from the successful conduct of which such essential benefits have resulted to zoological science.

It appears that the swan lately discovered, or at least identified as new to the records of British ornithology, and described by Mr. Yarrell* under the name of Bewick's swan (Cygnus Bewickii), is an inhabitant of the seacoast within the Arctic circle of America. It is much later in its northern migratory movements than its congener the trumpeterswan (C. buccinator). According to Lewis and Clarke, it winters near the mouth of the Columbia. Its nest is described by Captain Lyon (than whom few describe in a more agreeable manner) as built in a peat-moss, and being nearly six feet long, four and three-quarters wide, two feet high exteriorly, and with a cavity in the inside of a foot and a half in diameter. The eggs were brownishwhite, clouded with a darker tint. A more common species of swan in the interior of the fur-countries is the trumpeter above named. The great bulk of the skins imported by the Hudson's Bay Company pertain to this species.

The white pelican (Pel. onocrotalus) is frequent in the fur-countries as high as the sixty-first parallel. It haunts eddies beneath cascades, and destroys a great quantity of carp and other fish.

The great northern diver (Colymbus glacialis) is met with in considerable numbers in all the lakes of the interior, though seldom observed either in Hudson's Bay or along the shores of the Arctic Sea. It flies heavily, but swims with great swiftness. The black-throated species ( $C$. Arcticus), on the other hand, though common on the coasts of Hudson's Bay, more rarely makes its way into the interior. Most of the guillemot tribe (Uria troile, Brunnichii, grylle, and alle) frequent the Arctic seas of America.

We shall here close our account of the feathered races of these northern regions.

* Linn. Travis. vol. xvi, p. 445. 


\section{CHAPTER VIII.}

Some Account of the Fishes and other Zoologrcal Productions of the Northern Regions of America.

Sturgeon-Salmon-Trout-Char-Capelan-White Fish-Blue FishHerring-Pike-Burbot-Perih-Bull-head-Northern Insects-Their Natural Preservation from Cold-More Northern Extension of Tropical Forms in America than in Europe-Bees-Extension Westwards of the Honey-bee-Diptera-Meiville Island Spider-Butterflies.

THE fishes of the northern regions are of great importance as articles of food in countries where a nutritious diet is by no means easy to obtain ; and where, as we have seen in the course of our historical disquisition, tripe de roche, burnt bones, and fur-jackets are too frequently the sorry substitutes for better fare. We shall mention a few of the characteristic kinds.

A species of sturgeon called sterlet (Accipenser Ruthenus) abounds in the Saskatchawan. The fishery at Curnberland House is most productive during the spring and summer. This is a much smaller species than the $A$. huso. An individual weighing 60 pounds is considered large.

The Coppermine River salmon (Salmo Hermii) is shaped like a common salmon, with a somewhat larger head. Its size is inferior to that of the British salmon. It is captured in great quantities in the leap at Bloody Fall, on the Coppermine, in the months of July and August. Many varieties of trout also occur in the lakes and rivers of the northern parts of America; but as the kinds which frequent our own otherwise well known streams are still vaguely indicated by naturalists, the reader need not wonder that we have little definite information to communicate regarding those of such far distant lands. The Indians do not appear to designate their trouts by specific appellations, but use a general term; the Crees call them nammacons, the Chipewyans thlooecsinneh, and the Esquimaux arkallook. The vividness of their spots and markings seems to vary with the season; and the colour and consequent condition 
of the flesh are likewise liable to change. They attain at times to an enormous size ; Dr. Richardson frequently ob. served trouts weighing 40 pounds. In Manito or God's Lake, they are reported to attain the size of 90 pounds. A species nearly allied to the char (S. alpinus), but with the tail more forked, and a blunter snout, was taken in a lake in Melville Island.

The capelan or lodde (S. Græenlandicus) was observed in large shoals along the shallow shores of Bathurst's Inlet. The white fish (Coregonus albus) is named thlooaek by the Copper Indians, and tittameg by the traders. It varies in weight from three to eight pounds, and sometimes attains even a much greater size. It abounds in every lake and river of the American arctic regions, and forms a most delicious food, being eaten without satiety as almost the sole article of diet at some of the trading-posts for a series of years. Back's grayling (C. signifer) is the poisson bleu of the furdealers. This beautiful fish prefers the strong rapids, and rises eagerly at the artificial fly. It was found during the first expedition only in the clear rivers to the northward of Great Slave Lake, and measures about 16 inches exclusive of the caudal fin. The common herring (Clupea Harongus) was caught in Bathurst Inlet early in the month of August; and pike (Esox lacius?) are common in all the lakes. The burbot (Gadus lotu) is likewise a frequent fish in every lake and river. It preys indiscriminately on whatever other species it is able to swallow, and in the spring its stomach is generally crammed withjcray-fish to such a degree as to distort the shape of its own body.* It is little prized as food. There is a kind of perch, sufficiently common about Cumberland House, which resembles our common perch in shape, but at the same time differs in several respects from the European species. Its length to the caudal fin is about 19 inches. A peculiar cottus (C. polaris, Sahine), similar in its habits to C. gobia, was found to occur abundantly on the shores of North Georgia in pools of water left by the ebbing of the tide. The largest were not more than two inches long. t The six-horned bull-head (C. hexacornis), is also frequent in the Arctic seas. $\neq$

* Appendix to Franklin's First Journey, p. 724.

+ Supplement to the Appendix to. Parry's First Voyage, p. 213.

$\ddagger$ For sume notices of shells and other invertebrate animals of tho C c 
We have little to say of the insects of the northern regions. Cold is in general adverse to the production and increase of insect life, and even temperate climates are much less productive than tropical and equatorial regions, in relation to those tiny tribes. It is probable, however, that the distribution of many northern species is still unknown. It was formerly supposed that in Iceland there were none, and that even in Norway there were very few, and their absence from those countries was attributed to excess of cold. Horrebow contradicted this opinion in regard to Iceland, although Dr. Hooker, in his interesting " Recollections" of a tour in that island, states that he met with few, ${ }^{*}$ yet Olafsen and Provalsen, during their residence there, collected 200 different species in one small valley. $\dagger$

Otho Fabricius resided six years in Greenland, and collected only 63 species of the insect class properly so called.f In the still higher latitude of Winter Harbour, where Sir Edward Parry sojourned, only six species of insects were collected from the beginning of the month of September till the August following. In Greenland, according to Mr. Kirby, every order of insect has its representatives, except Orthoptera and Hemiptera; but in Melville Island, besides these deficiencies, neither coleopterous nor neuropterous species were observed; and even the mosquito, that shrill tyrant of the Lapland plains, appears to have ceased from troubling along those hyperborean shores. It must, however, be borne in mind, that insects can escape the extremes of cold, not only, as Mr. Macleay observes, by passing certain periods in the pupa or torpid state, but also by being while in that state usually buried in the earth, where they are but slightly sensible even of the most extreme rigour of winter. "What they chiefly require is the presence of heat during some period of their existence ; and the greater, within certain limits, is the heat, the more active will be their vital principle. On the American continent the extremes of heat and cold in the course of the year are, as is well known, incomparably greater than in places of the

Arctic Regions, consult the Supplement above named. See also a List of Zoophytes by Dr. Fieming, in the Appendix to Captain Parry's Second Voyage to the Arctic Regions.

* First edition, p. 272.

$\ddagger$ Fauna Grænlandica.

$\uparrow$ Voyage en Islande, $t$. $\mathbf{L}$. 
same latitude in Europe. We may, therefore, readily conceive how families of insects will inhabit a wider range of latitude in the former country than in the latter. We see also how insects may swarm in the very coldest climates, such as Lapland and Spitzbergen, where the short summer can boast of extraordinary rises in the thermometer; because the energy of the vital principle in such animals is, within certain limits, proportionate to the degree of warmth to which they may be subjested, and escapes in a manner the severe action of cold." " It is on the above principles also that Mr. Macleay accounts for what certainly at first seems an extraordinary circumstance in the geography of insects; namely, that their tropical structure extends much farther north in America than in Europe,-that is, in a manner directly the reverse of that which has been noted by botanists to occur in the vegetable kingdom. When we examine Copris carnifex, Cetonia nitida, Rutcla 6-punctata, and other insects from the neighbourhood of New-York, and compare them with species of the same families from Brazil, we shall find their difference of structure infinitely less than that which would result from a comparison of the entomological productions of the environs of Madrid with those of the banks of the Congo.

Mr. Macleay admits, that although in his opinion the insect tribes suffer less in cold climates than plants, it does not therefore follow that the prevalence of cold has no effect in relation to the destruction or prevention of insect life. In truth, the diminution of the number of species becomes very conspicuous as we advance towards the poles. But this the learned author of the Horce Entomologice supposes to be owing rather to the short continaance of the summer warmth, than to the lowness of its existing degree. In accordance with this view we certainly find that many insects, such as gnats, mosquitoes, \&c. which pass their larva state in water, - thus avoiding the extremest cold, and whose existence in the perfect state being naturally ephemeral, must, therefore, suffer little from the shortness of summer,-are nowhere more troublesome than among the moors and marshes of the north. On the other hand, the number of coleopterous species, which, being naturally longer lived,

* Horæ Entomologicæ, part i. p. 45. 
require a greater continuance of warmth, is sensibly diminished amid those dreary wastes.*

Several specimens of a species of caterpillar were found in Melville Island. They occurred in the vicinity of Salix Arctica and Saxifraga oppositifolia, and a new moth (Bombyx Sabini, K.) was found in a swampy part of the island. The honey-bee (Apis mellifica) is supposed to be not an indigenous but an imported species in America. Our land expeditions did not observe its occurrence to the north of Canada. The Americans have now settled the Missouri, as far as the 95 th meridian, and it is probable that the New-England men, in their journeys westward, carried hives along with them. According to Mr. Warden, the honey-bee was not found to the westward of the Mississippi prior to the year 1797; but it is now well known, and has been so for a considerable time, as high up the Missouri as the Maha nation; having proceeded westward 600 miles in fourteen years.t Such a distance seems great for these tiny creatures to advance by the ordinary process of swarming, even supposing that the flight of the new colonies was invariably in a western direction. It is at the rate of 43 miles a-year; but they have, perhaps, been smitten by the Yankee passion of settling beyond the clearings. $\neq$ A wild bee (Apis alpina, Fah. Bombus Arcticus, K.) of a black colour, with the base and apex of the thorax and the anterior half of the abdomen pale yellow, is very common within the Arctic Circle. $\oint$ "Scarcely any genus of the insect creation has so large a range as this of Bombus. It is found in the Old World and in the New,-and from the limits of phænogamous vegetation to the equator; but its metropolis appears to be within the temperate zone. The range of the species in question seems limited by the Arctic Circle, and to go from Greenland only westward, for it does not appear to

* Horæ Entomologicæ, part i. p. 46.

$\uparrow$ Statistical, Political, and Historical Account of the United States of America, vol. iii. p. 139.

$\ddagger$ Dr. Richardson lately informed me, that in the course of his north. ern journey, he saw some bees in very high latitudes resembling our common humblebee, but that he did not at the time ascertain the exact species, and the circurnstances under which he was then placed unfortunately provented his preserving specimens of the softer insects.

8 The insect above alluded to is a distinct species from the Apis alpina of Linn., which is black, with the upper side of the abdomen, al! but the base, covered with ferruginous hair. 
have been seen in Lapland or Iceland,* or other eastern parts of that circle." $\dagger$

Of the dipterous tribes we shall here mention only the Chironomus polaris of Kirby. The body is of a deep black, somewhat hairy. The antennæ are plumose. The wings are rather shorter than the body, of a milky hue, with prismatic reflections, and the marginal nervures black. The abdomen is slender and hairy. This species seems allied to the Tipulu stercoraria of De Geer, but exceeds it by twice the size. Along with Ctenophora Parrii it may be said to replace the Culices or gnats which prove so troublesome to navigators and travellers up to a certain high latitude. The species of the genus Chironomus, more especially, are often seen in our own country dancing in the sunbeams even during the depth of winter, when Culex is benumbed; and it was therefore to be expected, a priori, that the former would occupy a higher range, and approach nearer the pole than the latter. On the last day of Captain Parry's attempt to reach the North Pole over the ice, a species of Aphis was found in lat. $82^{\circ} 26^{\prime} 44^{\prime \prime}$, about 100 miles from the nearest known land. $\ddagger$ This may be considered as the extreme northern boundary of insect life.

A small spider was seen in great abundance in Melville Island, running on the ground, as well as on various plants, and leaping when alarmed. Mr. Kirby had an opportunity of examining only a single specimen, which was so defective from injury that he could not name with certainty the genus to which it belonged; but from its leaping propensities it was inferred to belong to Salticus of Latreille. To whatever genus it pertains, the specific name of $M \mathrm{Mel}$ villensis is now bestowed upon it.

$\mathrm{Mr}$. Scoresby brought a few insects from the east coast of West Greenland. Among these were two butterflies, Papilio palano, Linn. (Faun. suec. 1041), and Papilio dia, Linn. (Fab. Mant. ins. ii. p. 61, n. 581). Both of these were enumerated for the first time as productions of Greenland in the account of his voyage; for the only butterfly

* Hooker's Recollections of Iceland, Ist edition, p. 34.

t Supplement to the Appendix to Captain Parry's First Voyage, p. 217.

$\ddagger$ Narrative of an Attempt to reach the North Pole in Boats. 
met with on either coast by Fabricius was the Papilio Tullia of Muller.*

The entomology of the northern portions of the mainland of America is as yet known only through a few vague and superficial notices, from which we can deduce no positive results, and with which we therefore deem it unnecessary to trouble the reader. We expect ere long a valuable contribution on the subject from the skilful pen of Mr. Kirby. $†$

\section{CHAPTER IX.}

\section{Characteristic Features in the Botany of the Northern Regions of America.}

Mr. Brown's Observations on the relative Proportions of the two great Divisions of Phænogamous Plants-Beautiful small Willow from East Greenland-Notices of the more remarkable Species collected by Dr. Richardson-Galium Tinctorium-Cornus Alba-Phlox Hoodii-Vi. burnum Edule-Azalea Nudicaulis-Lilium Philadelphicum-Epilobium Angustifolium-Ledum latifolium-L. Palustre-Prunus Virglnians - Pyrus Ovalis-Crepis Nana-Cineraria Congesta-Pinus Nigra -P. Alba-P. Banksiana-P. Microcarpa-L. Lambertiana-Empetrum Nigrum-Myrica Gale-Populus'Trepida-Populus Balsamifera -Juniperus Prostrata-Splachnum Mnioides-Dicranum Elongatum -Gyrophora proboscidea-Hyperborea Pennsylvanica, Mecklenbergii, vellea-Cetraria Richardsonii-Fucus Ceranoides-Difficulties in the Determination of Arctic Species-Plants recently introduced to the British Gardens-Lathyrus Decaphyllus-Eutoca Franklinii-Lupinus Littoralis-Clarkia Puchella-Gerardia Capitata-New Dodecatheon -Andromeda Tetragona-Menziesia Empetrifolia-Azalea Lapponica -Dryas Drummondia.

Aztrovgh, as a subject of scientific and philosophical investigation, botany yields in interest to none of the other branches of natural history, and although a great poet and profound observer of nature has asserted that

"To him the meanest flower that blows can give Thoughts that do often lie too deep for tears,"

* Scoresby's Journal of a Voyage to the Northern Whale-Fishery, p. 424.

† The third volume of Dr. Richardson's Fauna Boreali-Americana, now in preparation, will contain a few notices of Serpents, a descrip tion of the Fishes, an account of the Insects (by Mr. Kirby), and a list of 'Testacea. 
yei, owing to the extension which we have assigned to the zoological department, our space we fear will scarcely suffice for more than a cursory sketch, even with the total exclusion of all lachrymose affection. Several of our best botanists have, of late years, devoted a portion of their attention to the Alora of the Northern Regions of America; but the subject has as yet made little progress beyond the indispensable preliminary of correct, though probably not yet completed, catalogues of certain districts. From these it is scarcely possible at present to select any such general features as would interest the majority of our readers ; but we shall in the mean while indicate the sources from which those who incline to investigate this branch of science may derive the most ample and accurate information.

A list of plants, collected in Melville Island by the officers of the first Polar voyage, has been published by Mr. Brown, with characters and descriptions of the new species.* This account was made up from the herbaria of Captain Sabine, Mr. Edwards, Mr. James Ross, Captain Parry, Mr. Fisher, and Mr. Beverley, whose names are here given in the order of the extent of their collections. Great difficulty was experienced by Mr. Brown in determining many of the species, either from their extremely variable character or the incomplete condition of the specimens, and occasionally also from the want of authentic individuals of an identical or analogous nature from other countries, with which the recent acquisitions might be compared. The plan originally followed by the great Scotch botanist in the preparation of his list was more extensive than that finally executed. It included remarks on the state and relative proportions of the primary divisions and natural orders to which these northern plants pertained-a comparison of that hyperborean vegetation with the productions of nearly similar climates-and observations on the range of such species as were ascertained to be common to Melville Island and other parts of the world. Towards the completion of that plan he had rnade considerable progress; but he found eventually that to have satisfactorily developed some of the subjects just named, would not only have required more time than he had then in his

* Supplement to the Appendix to Captain Parry's First Voyage, London, 1824. 
power to bestow, but also a more ample stock of materials than was at that period within his reach. If then so skilful an observer was unable to exhibit any general views on the subject, we hold ourselves to stand excused for their absence from this department of our present publication. In the list referred to the reader will find descriptions of several new or imperfectly-known genera and species, with admirable illustrative engravings from the unrivalled pencil of Mr. Bauer.

In Mr. Brown's earliest observations on the interesting subject of the relative proportions of the tivo primary divisions of phænogamous plants, he had arrived at the conclusion, that from $45^{\circ}$ as far as $60^{\circ}$, or perhaps $65^{\circ}$ of north latitude, the proportion of dicotyledonous to monocotyledonous plants gradually diminished.* From a subsequent consideration, however, of the list of Greenland plants given by Professor Geisecke, $\dagger$ as well as from what he had been able elsewhere to collect, regarding the vegetation of alpine regions, he had supposed it not improbable that in still higher latitudes, and at corresponding heights above the level of the sea, the relative numbers of these two divisions were again inverted; $\neq-i$ in the list of Greenland plants just. referred to, dicotyledones being to monocotyledones as four to one, or in nearly the equinoctial ratio; and in the vegetation of Spitzbergen, as far as it could be julged of from the materials hitherto collected, the proportion of dicotyledones appearing to be still further increased. This inversion in the cases now mentioned was found to depend at least as much on the reduction of the proportion of gramineæ, as on the increase of certain dicotyledonous families, especially saxifragex and cruciferæ. "The flora of Melville Island, however, which, as far as relates to the two primary divisions of phænogamous plants, is probably as much to be depended on as any local catalogue hitherto published, leads to very different conclusions-dicotyledones being in the present list to monocotyledones as five to two, or in as low a ratio as has been anywhere yet observed; while the proportion of grasses, instead of being reduced, is nearly double what has been found in any other part of the world

* Flinders' Voyage, ii. p. 538.

† Article Greenland, in Brewster's Encyclopædia.

† Tuckey's Congo, p. 423. 
(see Humboldt in Dict. des Sciences Nat. tom. 18, table at p. 416),-this family forming one-fifth of the whole phænogamous vegetation."

Prior to the publication of the list, from the prefatory remarks to which the preceding is an extract, a short catalogue of plants collected on the east coast of Greenland was published by Mr. Scoresby, with some remarks by Dr. Hooker. $t$ The female catkins of a willow, allied to Salix arenaria of Smith, are described as extremely beautiful, owing to the fine contrast between their almost black scales and the pure silky whiteness of their germens. This was the only arborous plant met with by $\mathrm{Mr}$. Scoresby. Its mode of growth was singular; for although it expanded to the extent of several feet, it so accommodated itself to the nature of that chilly climate, or was so acted upon by its ungenial influence, that it only spread laterally, and was never observed to rise higher than two or three inches from the ground.

In the same year with the preceding, the narrative of Sir John Franklin's first journey, already so often referred to, made its appearance. The appendix to that volume (No. vii. p. 729) contains a list of North American plants by Dr. Richardson, which, however, is not given as containing any thing like a full catalogue of the flora of the district through which the expedition travelled. During their summer journeys only a small portion of time could be allotted to botanical researches, and the constant and more important duties of the officers prevented their aiding the doctor at all times in the collection of specimens as sedulously as they inclined to do. Under unavoidable circumstances of a very harassing nature, a large proportion of plants may well be supposed to have escaped their notice; and the disastrous incidents attending their homeward journey across the Barren Grounds, from the shores of the Arctic Sea, forced them to leave behind the entire col-

\footnotetext{
* Supplement of the Appendix to Captain Parry's First Voyage, p. 262.

$\dagger$ Journal of a Voyage to the Northern Whale-fishery, Appendix, No ii. p. 410 .

In connexion with the last-named work the reader may also consult a Catalogue of Plants collected by William Jameson, Esq., surgeon, on the west coast of Greenland, drawn up by Dr. Greville, and published in the Memoirs of the Wernerian Society, vol. iii. p. 426 .
} 
lections formed during the summer of 1821 , with the exception of a few specimens collected on the banks of the Coppermine River, and which had previously been intrusted to Mr. Wentzel's care. Professor Schwægrichen, when in London, named the musci, and Dr. Hooker undertook the examination of the lichenes and fungi. Nothing more need be said to stamp a high value on those portions of the catalogue.

This list contains (besides a few specimens described in the addenda by Mr. Brown) above 660 species. These are referable to various classes in the following numerical proportions :-

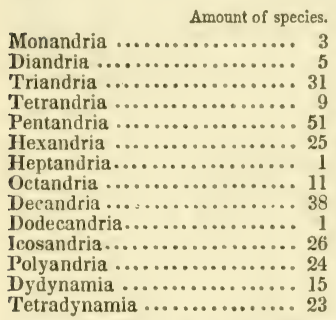

Amount of species.

Monodelphia ............. 1

Diadelphia ................ 23

Syngenesia............... 52

Gynandria ............... 8

Monæcia................... 39

Diæcia................. 24

Cryptogamia,

Filices .............. 19

Musci ............. 73

Hepaticæ ............. 16

Lichenes..............121

Fungi............... 19

Alga $\ldots \ldots \ldots \ldots \ldots \ldots$

We shall briefly notice a few species, remarkable for their economic or other uses. The juice of the Galium tinctorium is used indiscriminately with that of $G$. boreale, by the women of the Cree nation, for the purpose of dying their porcupine quills. The lead-coloured fruit of Cornus alba are called bear-berries (musqua-meena) by the Crees, because the bear is known to feed and fatten on them. A new species of phlox was discovered by the expedition, and named Phlox Hoodii, "as a small tribute," Dr. Richardson informs us, "to the memory of my lamented friend and companion, whose genius, had his life been spared, would have raised him to a conspicuous station in his profession, and rendered him an ornament to any science to which he might have chosen to direct his attention." This beautiful plant is a striking ornament to the plains in the neighbourhood of Carlton House, where it forms large patches, conspicuous from a distance. The red berries of the Viburmum 
edule, named winter-berries by the Crees, were observed to be highly ornamental to the woods. The bruised bark of the root of $A \approx a l c a$ nudicaulis is applied by the Indians to recent wounds. The Lilium Philadelphicum is called mouse-root by the Crees, because the common mouse of their country (a species of campagnol) is known to feed upon its scaly bulbs. The Canadian voyagers use the young shoots of Epilobium angustifolium as a pot-herb, under the name L'herbe fret. The Ledum latifolium, sometimes used as tea, is named kawkee-kee-pucquaw (evergreen, or always leaves), and also maskæg or medicine, because the natives think that the white residents drink its infusion as a medicine. The Ledum palustre, according to Dr. Richardson, forms a better substitute for tea than the plant just named.

The Prunus Virginiana grows to be a handsome small tree, rising on the sandy plains of the Saskatchawan to the height of twenty feet, and extending as far north as Great Slave Lake, where, however, it attains the height of only five feet. Its fruit, known under the name of choke-cherry, is not very edible in the recent state, but forms a desirable addition to pemmican when dried and bruised. The Pyrus ovalis of Pursh is a common plant as far north as lat. $62^{\circ}$, and abounds in the plains of the Saskatchawan. Its wood is greatly esteemed by the Crees, for the formation of arrows and pipe-stems; it is hence called bois de flêche by the Canadian voyagers. Its berries, about the size of a pea, are the finest fruit in the country, and are used by the Crees under the name of Messasscootoommeena, both fresh and dried. They make excellent puddings.

Among the Syngenesious plants we shall signalize only two examples. The Crepis nana, a singular species, appears to have been noticed by the land-expedition only on the banks of the Coppermine River. The polar voyagers collected it in Repulse Bay, Five Hawser Bay, and Lyon Inlet.

The Cineraria congesta, described by Mr. Brown, * varies from three to seven inches in height. The leaves are sometimes merely undulated, at other times furnished with long, spreading, sharp, unequal, tooth-like processes. Generally 
the flowers are collected into a remarkably compact head, but in two specimens examined by Dr. Hooker, ${ }^{*}$ sereral of the flower-stalks spring singly from the axils of the leaves up the whole length of the stem; in which case they are mostly single-flowered, truncated, and leafy; but always clothed, in common with the involucre, by a beautiful long and dense silky wool, by which character this species appears to be principally distinguished from $C$. palustris. Specimens of this plant were gathered by Dr. Richardson in Bathurst Inlet, on the shore of the Arctic Sea, on the 25th of July. According to Mr. Edwards, the individuals in Captain Parry's collection, which have elongated flowerstalks, were drawn out by having been made to grow on board ship; at least he has seen sucn treatment produce precisely that effect; and he adds that in its native place of growth he never observed the plant otherwise than romarkably dense and crowded in its inflorescence.

The black American spruce (Pinus nigra, Lamb.) is found in swampy situations as far north as lat. $65^{\circ}$, where it tcrminates along with the Betula papyracca. The white American spruce ( $P$. alba, Lamb.) is mentioned by Dr. Richardson as the most northern tree which came under his observation. "On the Coppermine River, within twenty miles of the Arctic Sea, it attains the height of twenty feet or more. Its timber is in common use throughout the country, and its slender roots, denominated Watapeh, are indispensable to canoe-makers for sewing the slips of birch-bark together. The resin which it exudes is used for paying over the seams of the canoes; and canoes for temporary purposes are frequently formed of its own bark. It is the only tree that the Esquimaux of the Arctic Sea have access to while growing, and they contrive to make pretty strong bows by joining pieces of its wood together." $\dagger$ The Scrub or gray pine (Pinus Banksiana, Lamb.), in dry sandy soils, prevails to the exclusion of all others. It is a handsome tree with long, spreading, flexible branches, generally furnished with whorled curved cones of many years' growth. It attains the height of forty feet and upwards in favourable situations; but the diameter of its trunk is greater in pron

* A ppendix to Parry's First Voyage, p. 397.

1 Appendix to Franklio's First Journey, p. 752. 
portfor to its height than that of the other pines of the country. It exudes less resin than $P$. alba. The Canada porcupine feeds upon its bark ; and its wood, from its lightness and the straightness and toughness of its fibres, is highly prized as canoe timbers. It was observed on the route of the overland expedition as far north as lat. $64^{\circ}$; but on the sandy banks of the Mackenzie it is said to attain to a still higher latitude.* The American larch ( $P$. microcarpa, Lamb.) was observed in swampy situations from York Factory to Point Lake, in lat. $65^{\circ}$. It was, however, of dwarfish growth in the last-named locality, seldom exceeding the height of six or eight feet.

One of the most magnificent of the newly-discovered forest-trees of North America is Lambert's pine (Pinus Lambertiana, Douglas). Its principal localities are probably to the south of the districts with which we are here more especially interested; but as its northern boundaries are not yet known, and as it forms in itself so fine a feature in this department of botany, we cannot leave it altogether unnoticed. It covers large districts in Northern California, about a hundred miles from the ocean, in lat. $43^{\circ}$ north, and extends as far south as $4^{\circ}$. It grows sparingly upon low hills, and the undulating country east of a range of mountains, running in a south-western direction from the Rocky Mountains towards the ara, where the soil consists entirely of pure sand. It furms no dense forests like most of the other pines of North America, but is seen scattered singly over the plains, more after the manner of Pinus rcsinosa. The trunk of this gigantic tree attains a height of from 150 to upwards of 250 feet, varying from twenty to nearly sixty feet in circumference; - thus far exceeding

"The tallest pine

Hervn on Norwegian hills to be the mast Of some great ammiral."

* Appendix to Franklin's First Journey, p. 752.-This is the only American species that makes any approach in habit and appearance to the Pinus sylvestris, commonly called the Scotch fir. A distinguished writer in the Quarterly Review ascribed the deterioration of our plantations of the last-named tree to the circumstance of our nurserymen finding it cheaper to import cones from Canada, than to pay for gathering them in Braemar,-a charge, however, from which the trade must be fully and freely acquitted, as the Pinus sylvestris does not in fact exist in America. 
The stem is remarkably straight, and is destitute of branches for about two-thirds of its height. The bark is uncommonly smooth for such large timber; of a light-brown colour on the south, and bleached on the north side. The branches are rather pendulous, and form an open pyramidal head, with that appearance which is peculiar to the abies tribe. The leaves are rigid, from four to five inches long, of a bright green colour, and grow in fives. The cones are pendulous from the extremities of the branches, and when ripe measure about eleven inches in circumference at the thickest part, and from twelve to sixteen inches in length. The scales are lax, rounded, and destitute of spines. The seeds are large, eight lines long and four broad, of an oval form. Their kernel is sweet and of a pleasant taste. The timber is white, soft, and light. It abounds in turpentine reservoirs; its specific gravity is 0.463 ; and the whole tree produces an abundance of amber-coloured resin. That which exudes from the tree when it is partly burned loses its usual flavour, and acquires a sweet taste, in which state it is used by the natives as sugar, being mixed with their food.* The seeds also are eaten when roasted, and they are likewise pounded into coarse cakes and stored for winter use.t

Numerous species of willow occur in the Northern Regions of America,-they are not yet well defined. The

* Mr. David Douglas, in Linn. Trans., vol. xv., and Edin. New Phil. Jour, vol. v. p. 401.

$\dagger$ IVe trust that our accomplished correspondent, Dr. Traill, of Liverpool, will excuse our making the following extract from one of his private letters. "Have you seen Douglas? I was greatly pleased with his intelligence and modesty. He gave me a most interesting sketch of his travels beyond the Rocky Mountains, and a simple but appalling account of the privations of a traveller in that part of the New World. 'The contrast between the vegetation of the western and eastern sides of the chain is striking. The rariety of oaks, juglandes, and elms, interspersed with magnolias and rhododendrons, form the striking peculiarities of the eastern,--but beyond the mountains only one species of oak is found, while neither elms, juglandes, nor magnolias occur, and only a single rhodndendron. It is, however, the favourite haunt of the giant-pine. Ile had measured several more than 250 feet high, - he saw some still taller, and took the circumference of a stem denuded of its bark, which was forty-eight feet in circumference, and at 190 feet from its base still bore a circumference of four and a half feet. The annual rings on one stem were ascertained to be nine hundred." 
plant which yields the whortleberry (Empetrum nigrum) is valuable in these inhospitable regions. Its fruit, after the first frosts, is juicy and very pleasant; it is much sought after and carefully hoarded by the different kinds of marmot, and forms the autumnal food of that species of duck called Anas hyperborea. The Indian women use the buds of Myrica gale to die their porcupine quills. The American trembling poplar (Populus trepida) occurs from Hudson's Bay as far to the northwar' of Great Slave Lake as lat. $64^{\circ}$. It is found to burn better in a green state than any other tree of the country. The form of the leaf-stalk in this species is highly curious, and beautifully accords with, and accounts for, its continual motion,-the upper part being rounded, and suddenly, at its junction with the leaf, becoming so thin and flat as to have scarcely sufficient strength to support it. The balsam poplar ( $P$. balsamifera) may be said to grow to a greater circumference than any other species in these northern regions. Although it burns badly when green, and gives little heat, its ashes yield a great quantity of potash. It was traced as far north as Great Slave Lake, and the south branch of the Mackenzie has been named Riviere aux Liards, from its frequent prevalence in that quarter. Great part of the drift-timber observed on the shores of the Arctic Sea belongs to this species of tree. It is called ugly poplar (matheh-meetoos) by the Crees.

The fruit of the common juniper is known under the appellation of crowberry to the last-named nation; and another species of that plant, of almost equal frequency ( $J u$ niperus prostrata), grows close to the ground, and sends out flageliform branches two yards long.

Of the Musci we shall here mention the Splachnum mnioides, which is very common on the Barren Grounds, where it forms little tufts, the roots of which are found always to include the bones of some small animal. $D_{l}$ cranum clongatum likewise occurs on those desolate districts where, with other species of the genus, it forms dense tufts very troublesome to pedestrians. These are called "women's heads" by the Indians, "because," say the latter, "when you kick them, they do not get out of the way ;"a fine commentary on a life of unsophisticated nature, and a 
beautiful illustration of the refined ideas which prevail in countries

"Where wild in woods the noble savage runs."

Of the lichenes, of which there are many species in these northern countries, we shall name a few examples. Gyrophora proboscidea is found on rocks on the Barren Grounds, and is more abundant towards the Arctic Sea than G. hyperborea. These two species, in common with G. Pennsylvanica and Mecklenbergii, were found in greater or less abundance in almost all rocky places throughout the northern portions of the over-land journey. They were all four used as food; but as our travellers had not the means of extracting the bitter principle from them, they proved injurious to several of the party by inducing severe bowelcomplaints. The Indians reject them all except G. Mecklenbergii, which, when boiled along with fish-roe or other animal matter, is agreeable and nutritions. The last-named lichen is, however, rather scarce on the Barren Grounds; and Dr. Richardson and his companions were obliged to resort to the other three, which, though they served the purpose of allaying the appetite, were found to be very inefficient in restoring or recruiting strength. The G. vellea is characteristic of moist and shady rocks, and is consequently most luxuriant in woods. It forms a pleasanter food than any of the species we have named; but it unfortunately occurs but sparingly on the Barren Grounds, where its presence would be most desirable. A new plant named Cetraria Richardsonii by Dr. Hooker, was found on these grounds generally in the tracks of the reindeer. It did not appear to occur to the southward of the Great Slave Lake. About a score of fungi were picked up by our scientific travellers. Exclusive of a conferva, and the fragment of a floridea, the Fucus ceranoides was the only alga observed in the Arctic seas.*

The Appendix to Captain Parry's second voyage was published in 1825, and contains, among other highly-prized contributions, a botanical Appendix by Dr. Hooker. When the extent of the collections examined by that accomplished

* Appendix to Franklin's First Journey, p. 763. 
botanist is considered, a greater accession of new epecies might have been expected than actually occurred; but this is perhaps to be explained by the circumstance of the countries explored during the second voyage being as it were intermediate between those previously examined,-Melville Island being to the north, and the continental portion of America, bordering the Arctic Sea, lying to the south of the districts to which we at present more immediately refer. This, in the opinion of Dr. Hcoker, diminished the probability of the occurrence of many new species. In point of mere number, however, the second collections very considerably exceeded those of the preceding voyage,-and this may be explained partly by the more southern latitude in which the plants were gathered, and partly by the length of time spent in those districts. Dr. Hooker conceives that, as an illustration of the botanical productions of a region extending from between lat. $62^{\circ}$ to $70^{\circ}$ north, his catalogue may be regarded as tolerably complete. The variety of cryptogamia is particularly great, and the herbaria were in such admirable order as to reflect the highest credit on the skill and assiduity of the gentlemen by whom they were collected and preserved.

"It may not be amiss," Dr. Hooker observes, " to notice here the extreme difficulty which attends the determination of what ought and what ought not to be considered as good species among Arctic plants. Vegetables of our own more southern latitudes often assume, in those frigid regions, an aspect quite different from what we are accustomed to see them wear ; and which, without referring to a very extensive series of specimens, might well be supposed to afford decided marks of specific distinction. Mr. Brown seems to be fully aware of this, and he speaks with caution of the identity of several of his new species. In more than one instance, after having drawn out a description of a supposed new individual, I have found cause to alter my opinion concerning it, and finally to consider it only as a variety of a wellknown kind; nor shall I be surprised if future observations should show that my Saxifraga plantaginifolia rnust be united to S. nivalis, and my Chrysanthemum grandiflorum to $C$. inodorum, though at first sight nothing van appear more distinct." **

* Appendix to Parry's Second Voyage to the Aretic Regions, p. 382. D d 2 
We shall conclude this branch of the subject by a few miscellaneous notices of recentiy-discovered species.

The ten-leaved everlasting pea (Lathyrus decaphyllus) was found on the banks of the Saskatchawan by Dr. Richardson and Mr. Drummond. It is adorned by fine heads of flowers, of a bright red colour before expansion, but which become purple as they open. This is an exceedingly ornamental plant, measuring about three feet in height. It was first raised in this country by Mr. Patrick Neill, of Canonmills, a gentleman well known for his encouragement of horticulture, and for his general attainments in many branches of natural science.

Franklin's eutoca (Eutoca Franklinii).* This interesting annual was discovered by Dr. Richardson during the first over-land expedition. It was found growing in abundance among trees that had been destroyed by fire, on the banks of the Missinnippi, and was named by Mr. Brown in honour of the leader of the gallant band. $\dagger$ It has now become well known in our gardens, the seeds collected during the second expedition having been pretty generally distributed. It is a hardy plant, which recommends itself to notice by the profusion of its bright blue-coloured blossoms. $\neq$

The seashore lupin (Lupinus littoralis). $\oint$ This ornamental and hardy perennial was discovered by Mr. Douglas, who found it "growing abundantly on the seashore of North-west America, from Cape Mendocino to Puget's Sound. Its tough branching roots are serviceable in binding together the loose sand, and they are also used by the natives of the river Columbia as winter food, being prepared by the simple process of drawing them through the fire until all their moisture is dissipated. The roots are then tied up in small bundles, and will keep for several months; when eaten, they are roasted on the embers, and become farinaceous. The vernacular name of this plant is Sommuchtan; and it is the liquorice spoken of by Lewis and Clarke, and by the navigators who have visited the northwest coast of America.

* Botanical Magazine, t. 2985.

$\uparrow$ Addenda to Appendix to Franklin's First Journey, p. 764, and tab. 27.

$\mp$ Dr. Hooker, in Bot. Nag.

I Ibid. t. 2952. 
We may add that $\mathrm{Mr}$. Douglas has enriched our gardens by upwards of ten now species of this fine genus.

Beautiful Clarkia (Clarkia pulchella).* This hardy annual deserves its specific name, as it is really one of the most beautiful which has been recently introduced into our gardens. It was first discovered by $\mathrm{Mr}$. Lewis on the Kooskoosky and Clarke Rivers, but was afterward found by Mr. Douglas extending from the great falls of the Columbia to the Rocky Mountains, and seeds were forwarded by him to the London Horticultural Society. The flowers are generally of a fine lilac colour, but a pure white variety is also known.

Mr. Douglas discovered in the northern parts of America, and introduced into the British gardens, about fifteen new species of Pentstemon, all of which are ornamental, and many exceedingly beautiful herbaceous plants. To the same intelligent and indefatigable collector we are also indebted for several fine species of CEnothera or tree primrose. We owe to Dr. Richardson and Mr. Drummond the introduction to our gardens of the following species:-viz. Gerardia capitata, a handsome perennial; an apparently new species of Dodecatheon, which has flowered this summer in the Edinburgh Botanic Garden; Andromeda tetragona, Menziesia empetrifolia, Azalea Lapponica (three very beautiful small shrubby plants), and Dryas Drummondii. The last-named plant bears yellow flowers. Of the other two known species of the genus, one of which is a native of the mountains of Scotland, the flowers are white.

* Dr. Hooker, in Bot. Mag. t. 2918. 


\section{CHAPTER X.}

\section{Sketch of the Geological Features of some of the Northern Districts of America.}

Frozen Subsoil of IIudson's Bay-Primitive Rocks of Hayes RiverHill River-Borders of Knee Lake-Remarkable Rock-island of Mag'netic Iron Ore-Lake Winipeg - Limestone District-Fort Chipewyan -Carp Lake-Gneiss Formation of the Barren Grounds-Transparent Waters of Great Bear Lake-Fort Franklin-Bear Lake River-Lignite Formation of Mackenzie River-Spontaneous Fire-Pipe ClayAlluvial Islands at the Mouth of the Mackenzie-Copper MountainsCoppermine River-Islands of the Arctic Sea-Arctic Shore-Cape Barrow-Galena Point-Moore's Bay-Bankes' Peniusula-Barry's Island-Cape Croker-Point Turnagain-General Occurrence of the New Red Sand-Stone-Hood's River-Wilberforce Falls-Gneiss Formation-General Summary.

TIIE great extent of country traversed by our over-land adventurers, the dreary continuance of that universal snow, which so long rendered the surface of the earth in many places almost inaccessible, the frequent journeys in canoes, and the difficulties which almost perpetually prevailed in the way of transporting weighty articles, prevented a complete or very satisfactory knowledge being obtained of the geological structure of the Northern Regions of America.* For the reasons stated below, we shall here confine our observations to certain restricted districts in those regions.

Between the fifty-sixth and fifty-eighth parallels the western shores of Hudson's Bay are extremely flat, and the depth of water decreases very gradually on approaching

* In the fourteenth volume of the Family Library, entitled "Narrative of Discovery and Adventure in the Polar Seas and Regions," the reader will find a chapter on Arutic Geology by Professor Jameson, in which the characteristic formations of Cherie Island, Jan Mayen's Island, Spitzbergen, Old Greenland, and the various insular and continental shores explored by the expeditions under Captains Ross and Parry, are described and commented on. So far, therefore, as regards many of the great North-eastern regions of America, we beg to refer the reader to Professor Jameson's skilful summary. See also observations on the Rock Specimens collected during the First Polar Voyage, by Charles Konig, Esq. Supplement to the Appendix, p. 247. 
them. Dr. Richardson states that in seven fathoms of water the tops of the trees are just visible from a ship's deck. Large boulder-stones are scattered over the beach, and sometimes form shoals as far as five miles from shore. These are, of course, troublesome and dangerous to boats. Hayes and Nelson Rivers enter Hudson's Bay about the central portion of this quarter. They are separated on reaching the coast merely by a low alluvial point of land, on which York Factory is stationed. A low and uniformly swampy aspect characterizes the surrounding country and the banks of Hayes River at least for fifty miles inland. The upper soil presents a thin stratum of half-decayed mosses, immediately under which we find a thick bed of tenacious and somewhat slaty bluish clay containing boulderstones. Forests, consisting chiefly of spruces, larches, and poplars, occur, but the individual trees, except under local circumstances of a favourable nature, are of a small size.

The subsoil is generally frozen, and as it consequently retains a great deal of the surface-water, swamps of sphagna and other mosses are always being formed; but the bright summer days, though long, are few, and as vegetation thus decays but slowly, little peat occurs. During a favourable season the ground thaws to the depth of about four feet; but there still remains, it is said, a frozen bed of ten or eleven feet, beneath which we find loose sand. As the earth is not thus permanently frozen in the interior countries of North America, the ungenial condition of the soil about York Factory ought probably to be attributed to the neighbourhood of the sea, which is too much encumbered with ice during winter to mitigate the severity of those naturally frost-bound regions, and being laden along shore with numerous icebergs and other insulated masses, even to the middle of August, must of course diminish the intensity of the summer heat.*

The boulder-stones just mentioned show that there occur in the district of Hayes River several primitive rocks, such as.red granite, hornblende rock, gneiss, and syenite; of the transition class, graywacke; and of the secondary class, red sandstone, belonging probably to the new red sandstone

* Appendix to Franklin's First Journey to the Shores of the Polar Sea, p. 499. 
formation, in which is included the rothegende and variegated sandstone. Two kinds of limestone likewise occur in this district.

The banks of Steel River, the principal branch of the Hayes, present the same general characters as those of the stream into which it flows. The same may be said of Fox and Hill Rivers, the union of which forms the Steel River. However, on the lower parts of Hill River the banks are more varied in their outlines, and rising more precipitately and from a narrow channel, they attain to an elevation of nearly 200 feet. About a mile below the Rock Portage, that is, about 100 miles from the sea, rocks first occur in situ. They consist of gneiss, and rise in the channel of the river from beneath lofty banks of clay. This gneiss formation seems to extend to Lake Winipeg, and contains subordinate beds and veins of granite, and beds of hornblende rock, and mica-slate. At the Swampy Portage a bed of red felspar occurs. It contains small grains of epidote, and at the Upper Portage hornblende-slate was observed, alternating with gray gneiss, slightly intermingled with hornblende, together with beds of quartz rock containing precious garnets. At the Lower Portage on Jack River (the name of Hill River after crossing Swampy Lake) a red granite occurs. The rocks on Jack River are low, with a very spare covering of soil ; the woods are thin, and the surrounding country flat. The borders of Knee Lake present similar characters; but in one spot which was examined on account of its exhibiting a more luxuriant growth of trees, the soil was still thin, but the subjacent rock consisted of primitive greenstone, with disseminated iron pyrites. "About half a mile from the bend or knee of the lake," says Sir John Franklin, "there is a small rocky island, composed of magnetic iron ore, which affects the magnetic needle at a considerable distance. Having received previous information respecting this circumstance, we watched our compasses carefully, and perceived that they were affected at the distance of three hundred yards, both on the approach to and departure from the rock: on decreasing the distance they became gradually more and more unsteady, and on landing they were rendered useless ; and it was evident that the general magnetic influence was totally overpowered by the local attraction of the ore. 
When Kater's compass was held near to the ground, on the north-west side of the island, the needle dipped so much that the card could not be made to traverse by any adjustment of the hand; but on moving the same compass about thirty yards to the west part of the islet, the needle became horizontal, traversed freely, and pointed to the magnetic north."*

We are indebted to Sir Alexander Mackenzie for the valuable observation, that tle principal lakes in these northern quarters are interposed between the primitive rocks and the secondary strata which lie to the westward of them. Of this Lake Winipeg affords a good example. It is a long narrow sheet of water, bounded on its eastern side by primitive rocks, which are mostly granitic, while horizontal limestone strata form its more indented western shore.

The north shore of Lake Winipeg is formed into a peninsula by Play-Green Lake and Limestone Bay. Steep cliffs of clay are here prevalent, similar to those which preceded the gneiss in Hill River, but containing rather more calcareous matter. The beach is composed of calcareous sand, and fragments of water-worn limestone, of which there are two kinds; the one yellowish-white, dull, with conchoidal fracture and translucent edges; the other bluish and yellowish-gray, dull, with an earthy fracture and opaque. Dr. Richardson did not observe any rocks of the former kind in situ in this neighbourhood, although cliffs of the latter were apparent on the west side of Limestone Bay, and continued to bound the lake as far as the mouth of the Saskatchawan, and were reported to spread down the whole of its western shore.

The extension of the limestone deposites of Lake Winipeg, in a westerly direction, has not been ascertained, but it has been traced as far up the Saskatchawan as Carlton House, where it is at least 280 miles in breadth.

This limestone extends over a vast tract of country, and may in general be characterized as compact, splinty, and yellowish-gray. It is very testaceous, and large portions of it are entirely composed of bivalve shells. In the journey up the Saskatchawan it was traced to the Neepewan, a distance of 300 miles, where it is either succeeded or covered

* Journey to the Shores of the Polar Sea, p. 36 . 
by cliffs of calcareous clay. It is probable that the limestone formation not only extends over a vast portion of the plains, but also runs parallel to the Rocky Mountains as far as Mackenzie River. Between it and the Rocky Mountains, rocks of the coal formation occur; and beds of burning coal have been known for many years or the upper parts of the Saskatchawan, as well as on the last-named river. One of the most marked characteristics of the limestone formation is the entire exclusion of foreign beds. It was never observed in association with any other rock, except, perhaps, on Elk River, where it appeared in contact with compact earthy marl and slaggy mineral-pitch, or bituminous sandstone; and on Coppermine River, where rolled fragments of a similar stone were found connected with layers of dark flinty slate. Salt springs and lakes exist from twelve to twenty miles to the northward of Carlton House.

In Athabasca Lake Sir John Franklin's party came again upon the edge of the primitive formation. Fort Chipewyan seemed to stand upon a granite rock, and a little to the eastward a reddish granite is associated with gray gneiss. Granite is the most abundant rock on Slave River; but it disappears about a mile and a half below the Portage des Noyes, and the banks from thence to Slave Lake are alluvial. At the mouth of the Yellow Knife River, and in Lake Prosperous, mica-slate prevailed; and between Rocky and Carp Lakes the granite contains many beds of mica-slate, often passing into clay-slate. Here the country is tolerabiy wooded, and white spruce occupy the rocky situations, Pinus Banksiana the sandy spots, and aspen the low moist places.*

At Carp Lake the hills are of lower altitude, the valleys are less fertile and have fewer trees, and these features seem to characterize the commencement of the gneiss formation, which extends over the great district to the eastward of the Coppermine River, termed by the Indians the Barrcn Grounds. The soil is inimical to almost every species of vegetation. The summits of the hills about Fort Enterprise are composed of a durable red granite, and large masses of the same substance are scattered over their surface. On

* Appendix to Franklin's First Journey to the Shores of the Polar Sea, p. 520. 
an arm of Point Lake, forty-five miles due north of Fort Enterprise, the rocks belong to the transition class. The light blue-coloured waters of Great Bear Lake are very transparent, more especially in the vicinity of the primitive mountains of M'Tavish Bay. A piece of white rag, when sunk, did not disappear till it had descended to the depth of fifteen fathoms. The surface of Bear Lake is not supposed to be 200 feet above the Arctic Sea, and as its depth is much greater than that amount of ftet, its bottom must consequently be below the level of the sea.* At the mouth of Dease's River, the hills are five or six hundred feet high, and are composed principally, if not entirely, of dolomite, in horizontal strata. The northern shores of Bear Lake are low, and skirted by numerous shoals of limestone boulders. At the foot of the Scented Grass Hill, a rivulet has made a section to the depth of 100 feet, and there shaly beds are seen interstratified with thin layers of blackish-brown earthylooking limestone, containing selenite and pyrites. Globular concretions of that stone, and of a poor clay iron-stone, also occur in beds in the shale. The suifaces of the slate-clay were covered by an efflorescence of alum and sulphur, and many crystals of sulphate of iron lie at the bottom of the cliff, and several layers of plumose alum, half an inch in thickness, occur in the strata. At the base of Great Bear Mountain, the bituminous shale is interstratified with slateclay, and Dr. Richardson found imbedded in the former a single piece of brown coal, in which the fibrous structuro of wood is apparent. $†$

On the northern shore of Keith Bay, about four miles from Bear Lake River, stands Fort Franklin, upon a small terrace, which is elevated about thirty feet above the lake. The bottom of the bay, wherever distinguishable, was observed to be sandy, and thickly strewed with rounded primitive boulders of great size, which were particularly abundant near the river,-and the waters of the cape formed by Scented Grass Hill were also strewed with large square blocks of limestone. All these boulders must have been carried from the parent rocks by a current flowing from the

* In M'Tavish Bay, near the shore of Great Slave Lake, forty-five fathoms of line did not reach the bottom. Some of the great lakes of Canada are supposed to descend 300 feet below the "Ocean's brim."

† Appendix to Franklin's Second Journey, p. 6. 
east. Two varieties of granite which occur among thems were recognised as forming abundant rocks at Fort Enterprise, which lies about 170 miles south-east from M'Tavish Bay. The soil in the vicinity of Fort Franklin is sandy or gravelly, and covers to the depth of one or two feet a bed of clay of unknown thickness. This clay continues firmly frozen during the greater portion of the year, and the thaw seldom penetrates more than a couple of feet into the surface of the earth.

Bear Lake River is about seventy miles long, from its origin in the lake tiil it falls into the Mackenzie, and its breadth is never less than 150 yards, except at the rapid. Sections made by the river generally present sand or clay, - the former probably proceeding from the disintegration of a friable gray sandstone, which occasionally shows itself in the more solid form. The walls of the rapid are about three miles long, and 120 feet high. They are composed of horizontal beds, the lower of which consist of an earthylooking stone, intermediate between slate-clay and sandstone, having interiorly a dull yellowish-gray colour. These beds are separated by thin slaty layers, of a substance similar in appearance, but harder, which contain impressions of ferns, and from the debris at the bottom of the cliff Dr. Richardson gathered impressions of the bark of a tree (lepidodendron) and some ammonites in a brown iron-shot sandstone. These are regarded by Mr. Sowerby as of a new species. They contain sulphate of barytes, and are supposed to be referable to some of the oolites near the Oxford clay.

We may here notice the remarkable lignite formation of Mackenzie River. The formation which constitutes its banks consists of wood-coal in various states, alternating with beds of pipe-clay, potter's clay (occasionally bituminous), slate-clay, gravel, sand, and friable sandstones, and occasionally with porcelain-earth. These strata are usually horizontal, and as many as four beds of lignite are exposed in some places, of which the upper are above the highest river floods of present times. The lignite itself is pretty compact when recently detached; but it soon splits into rhomboidal pieces, separable into more or less delicate slaty portions. When burut, it produces little smoke or flame, and leaves a browinish-red residuum, not one-tenth of the 
original bulk. But the smell is very fetid, resembling that of phosphorus. It was found unfit for welding iron when used alone, but it sufficed when mixed with charcoal. However, the smell was still most annoying. A frequent form of this lignite is that of slate, of a dull brownishblack colour, with a shining streak.

These remarkable beds seem to take fire spontaneously when exposed to the action of the air. They were found burning by Sir Alexander Mackenzie, when he passed downwards in 1789, and are supposed to have been on fire ever since. Large slips of the banks take place in consequence of the destruction of the coal, and it is only when the debris has been washed away by the river that good sections become visible. "The beds were on fire when we visiled thern; and the burnt clay, vitrified sand, agglutinated gravel, \&rc. gave many spots the appearance of an old brick-field."**

The pipe-clay is also sufficiently singular to deserve a special notice. It occurs in beds from six inches to a foot in thickness, and chiefly in contact with the lignite. Its colour is yellowish-white; in some places, however, it is light lake-red. It is used by the natives as an article of food in times of scarcity, and is said to be capable of sustaining life for a considerable time. It is known to the traders under the name of white mud. They wash their houses with it.

The alluvial islands at the mouth of the Mackenzie separate the various branches of that great river. These islands are either partially or entirely flooded in the spring; their centres are depressed, and are either marshy or occupied by a lake. Their borders, however, are more elevated, and are well clothed by white spruce-trees. These, and whatever other trees are produced in the islands, suddenly cease to grow about latitude $68^{\circ} 40^{\prime}$.

The famous Copper Mountains, so called, consist principally of trap rocks, which seemed to Dr. Richardson to be imposed upon the new red sandstone, or the flcetz limestone which covers it. They rise to a height of eight or nine hundred feet above the level of the river, and present a softish outline at a distance; but on a nearer view they

* Appendix to Franklin's Second Journey, p. 18. 
seem composed of ridges, many of which have precipitous sides. The summits are stony and uneven. The largest pieces of copper are found asseciated with prehnite, and the Indians are careful to search for ore wherever they observe pieces of the last-named mineral lying on the surface. The original repository or vein of copper ore does not appear to have been hitherto observed; but judging from specimens picked up by our overland expeditions, it most probably traverses felspathose trap. Ice-chisels have been observed in the possession of the Esquimaux measuring twelve or fourteen inches long, and half an inch in diameter, formed of pure copper.

Another range of trap hills occurs at the distance of ten miles to the northward of the Copper Mountains. This range is about twenty miles from the Arctic Sea, and beyond it the country is very level, with a subsoil of light brownish-red sandstone. These desolate plains nourish only a coarse short grass, and the trees, which had previously dwindled to scraggy clumps, entirely disappear.

At the mouth of the Coppermine River there occurs a low ridge of greenstone; and from thence to Bloody Fall, which is a distance of about ten miles, the country is very level, with the exception of some ridges of trap, by which it is traversed. The channel of the river is sunk nearly 150 feet below the level of the surrounding country, and is bounded by cliffs of yellowish-white sand, and sometimes of clay, beneath which beds of greenstone occasionally crop out.

The islands in this quarter of the Arctic Sea are invariably rocky. They present a remarkable uniformity of appearance, and are very generally bounded by mural prec1pices of trap-rock clinkstone or claystone. But the main shore presents a greater diversity. For sixty miles eastward of Coppermine River, the beach is low and gravelly, but towards Tree River the trap rocks reappear and form a steril and rocky coast. At Port Epworth the valleys were stony, and almost entirely destitute of herbage. The rocks observed were liver-brown clinkstone porphyry, with a few beds of earthy greenstone, and the same formation extends to the mouth of Wentzel's River, to the eastward of which a projection of the coast forms Cape Barrow. When Dr. Richardson rounded this cape the weather was extremely 
foggy, but the rocks examined consisted of a beautiful admixture of red and gray granite, forming steep and craggy peaks which rose abruptly from the water to the height of 1500 feet. At Detention Harbour the granite hills terminate abruptly, or recede from the coast, giving place to less elevated strata of gneiss, in which beds of red granite are enclosed. A vein of galena was observed running through the gneiss for two hundred yards at the spot named in consequence Galena Point.* A mass of indurated iron-shot slaty clay occurs on the western point of Moore's Bay, and the promontory which forms the eastern side of that bay is composed of trap rocks and claystone porphyry, whose mural precipices constitute the sides of narrow valleys, opening at either end towarus the sea. An iron-shot clinkstone porphyry, with a columnar aspect, prevails from Moore's Bay to the entrance of Arctic Sound. The eastern shore of that sound is covered with grass, and scarcely exhibits any naked rock; but the clinkstone porphyry reappears on Bankes's Peninsula, along with an earthy-looking greenstone, and forms as usual parallel ranges of mural precipice. On Barry's Island the trap rocks form cliffs from 50 to 160 feet high, superimposed on thick beds of indurated clay or marl. A red amygdaloidal rock, containing beautiful pebbles of carnelian, chalcedony, and imbedded jaspers, was observed on the north side of the island.

Trap rocks, for the most part greenstone, and sandstone of the new red formation, characterize Sir James Gordon's Bay; but to the north of Fowler's Bay the gneiss reappears, with beds of granite and hornblende gneiss. Hexagonal crystals of hornblende, above a foot long, were observed imbedded in the gneiss near Point Evritt, and the islands in the offing consisted as usual of flœtz trap or porphyry. Cape Croker is composed of red sandstone, of which the debris forms a shelving and utterly barren shore. Grayish-white sandstone, associated with or passing into slaty-clay, was visible on the northern shore of Melville Sound, wherever the barren clayey sand was washed away. Cliffs of greenstone, or of clay-stone porphyry, superimposed on the flat strata, presented the appearance of islands, when seen from the opposite coast, as our exploring party

* Appendix to Franklin's First Journey, p. 531. E e 2 
entered the sound, and had the low connecting land been then visible, a tedious and unnecessary circumnavigation of the sound itself would have been saved. The coast exhibited the same appearance as far as Point Turnagain, the most eastern point attained by the overland expeditions.

On a general view, it appears that the new red sandstone formation prevails along those portions of the North American Arctic shores. "All the islands visited," says Dr. Richardson, "were formed of trap or porphyry belonging to that formation; and, judging from similarity of form, the rocks of the other islands belong to the same class. The gneiss formation is next in extent; and, indeed, it appears to run nearly parallel to the coast within the red sandstone from Cape Barrow, across Hood's River above Wilberforce Falls, to the bottom of Bathurst's Inlet, and from thence to Hope's Bay, on the western side of Melville Sound. The only foreign beds we observed in the gneiss were granite, perhaps quartz-rock and hornblendic gneiss or syenite. We saw no clay or mica-slate, nor did we observe any formations intermediate between the gneiss and new red sandstone; nor, except at Cape Barrow, where granite predominates, any other formation than the two just mentioned. Our opportunities for observation, however, were not extensive; the necessity of proceeding without delay limiting our botanical and geognostical excursions to the short period that was required to prepare breakfast or supper." *

From Point Turnagain the party proceeded to Hood's River, which they traced to some distance. Near its mouth that river is from 100 to 300 yards in width, and is bounded by steep high banks of clay, reposing on flœtz rocks. At Wilberforce Falls, which are six or seven miles above the second rapid, the river makes a striking descent of about 250 feet into a chasm, the walls of which consist of lightred felspathose sandstone, belonging, as Dr. Richardson supposes, to the old red sandstone formation, or that which lies under coal, and occasionally alternates with transition rocks.t A short distance above these falls the gneiss formation appears, and produces hills precisely similar to those about Fort Enterprise. On quitting Hood's River our ex-

- Appendix to Franklin's First Journey, p. 533.

† Ibid. p. 534. 
ploring party ascended from the valley through which it flows, and entered upon an even, clayey, and very barren district, partially covered by shallow lakes. This plain country continued nearly as far as Cracroft's River, where the gneiss reappeared, and presented those bleak hills and precipices so characteristic of the Barren Grounds. The gneiss formation was observed to continue without essential change to Obstruction Rapid, between Providence and Point Lakes, where it united with the Fort Enterprise district formerly alluded to.

The preceding geognostical details, and others into the consideration of which we cannot here enter, render it apparent that the general distribution and connexion of the hills and mountain-masses of these northern regions are nearly the same as geologists have observed to characterize similar materials in other portions of the earth. The primitive rocks occur in their usual relations; and gneiss, attended by an extremely scanty vegetation, appears to be the most extensively distributed. Granite was the next in frequency; after which may be placed mica-slate. Clayslate and protogine were the least abundant. The granite of Cape Barrow was intersected by veins of augite greenstone of the same description as those which occur in the granite districts of Great Britain, and the primitive rocks in general were found to be traversed by veins of felspar, quartz, and granite.

The transition rocks, consisting principally of clay-slate and graywacke, bore a strong resemblance to those in Dumfries-shire, - a fact which did not fail to attract the attention of Dr. Richardson, himself a native of that district.

In regard to the secondary formations, the facts observed by Dr. Richardson show the existence-First, Of the old red sandstone, or that which lies under coal, and occasionally alternates with transition rocks : Second, Of the coal formation, which was ascertained to occur in certain districts of Mackenzie River, and towards the Rocky Mountains : Third, Of the new red or variegated sandstone, an important formation of considerable extent, which contained, as it is known to do in the Old World, gypsum and beds of salt, or of muriatiferous clay, affording saline materials for the im- 
pregnations of the salt springs which issue from it: Fourth, Of the secondary limestone belonging to that vast deposite which lies above the new red sandstone, and beneath chalk, and which occupies extensive tracts in Britain and other parts of Europe: Fifth, Of the secondary trap and porphyry rocks, in the composition and character of which one of the most interesting features is undoubtedly the frequent occurrence of native copper, both among the Copper Mountains themselves, and along the Arctic shore.

The alluvial deposites consist, as usual, of sand, gravel, rolled blocks, boulder-stones, and the debris of various rocks. We may conclude by observing, in the words of Dr. Richardson, to whom we are deeply indebted for the information presented in this volume, that the foregoing details make it manifest " that in the regions we traversed the rocks of the primitive, transition, secondary, and alluvial classes have the same general composition, structure, position, and distribution as in other parts of America which have been examined; and as these agree in all respects with the rock formations in Europe and Asia, they may with propriety be considered as universal formations-parts of a grand and harmonious whole-the production of Infinite Wisdom."

"Stand Still aND BEHOLd the wONDRous WORKS OF God,-THE WONDROUS wORKS OF HIM WHICH IS PERFECT IN KNOWLEDGE."

"ReMEMBER THAT THOU MAGNIFY HIS WORK WHICH MEN BEHOLd. EvERY MAN MAY SEE IT; MEN MAY BEHOLD IT AFAR OFF."

"O LORD, HOW MANIFOLD ARE THY WORKS! IN WISDOM HAST THOU MADE THEM ALL! THE EARTH IS FULL OF THY RICHES."

"Before the mountains Were brought Forth, or EVER THOU HADST FORMED THE EARTH AND THE WORLD, EVEN From EVERLASTING TO EVERLASTING, THOU ART God." 


\section{APPENDIX.}

\section{REMARKS}

ON

\section{A. LATE MEMOIR OF SEBASTIAN CABOT,}

WITH A

VINDICATION OF RICHARD HAKLUYT.

" Floreat Historia Britannica, recordis authenticisque expromatur: Scribatur lente, mature, ordinate, sincere, dilucide, sine partium studio, sine yravo consilio, sine omni vili affectu viris literatis indigno."-MADox, Disceptatio Epistolaris De Magno Rotulo Scaccarii.

THE reader is already aware, that in the present volume the discovery of North America, in the reign of Henry VII., has been exclusively ascribed to John Cabot, a Venetian, who had settled as a merchant at Bristol. The author of a late work* has attributed this noted extension of geographical knowledge solely to the subject of his biography, Sebastian Cabot, the son of John. According to him, it was Sebastian who projected the expedition in which the discovery was made, - it was Sebastian who conducted the expedition, -it is doubtful whether John Cabot accompanied the voyage at all, and it is certain, if he did, it was simply as a merchant who traded on his capital. The biographer has brought forward his arguments in support of this theory, in the fifth chapter of his work, entitled Comparative Agency of John

* Memoir or Sebastian Cabot. 
and Sebastian Cabot; and it is in the course of these arguments that he has made an attack upon the integrity and honesty of Richard Hakluyt, a writer to whom the history of maritime discovery is under the deepest obligations. These two points, therefore,-the discovery of North America, and the credit due to the evidence of Hakluyt,-must necessarily be considered in conjunction; and we trust we shall convince every impartial reader of the accuracy of our assertion, that John Cabot was the discoverer, and that the attack upon Hakluyt is perfectly unfounded.

Before, however, proceeding to the more immediate subject of inquiry, we may be permitted to say, that although it becomes our duty to point out repeated and material errors, and in some instances considerable injustice committed by the biographer of Cabot, we are anxious to avoid that peculiar asperity which he has unnecessarily mingled with a subject so remote that it may surely be approached in a spirit of great calmness and impartiality. We wish to employ no expression which may give a moment's unnecessary pain to the biographer. His Memoir of Cabot, as may be seen from the references to it in the course of this volume, has been frequently of use to us. Although rather a piece of biographical and historical criticism than a pure biography, it is a meritorious work; it points out to the reader some recondite sources of information,-its deductions and arguments are often acute and ingenious, - and, confused and deficient as it is in its arrangement, it contains occasional passages which are eloquently written. But it is impossible not to regret that there is infused into the whole book a more than ordinary proportion of that bitter and querulous spirit which, in a greater or less degree, seems inseparable from the lucubrations of the antiquary, - - that the author has poured abuse, contempt, and ridicule upon those who have fallen into errors which he sometimes has, and at other times imagines he has, detected,-and that he is unscrupulous in imputing unfair and ungenerous motives to those who little deserve such an accusation. Robertson, Forster, Henry, Campbell, Southey, Barrow, and other able writers, are attacked in unmeasured terms, as the arch propagators of all that is erroneous and superficial on the subject of maritime discovery ; and our excellent friend Richard Hakluyt, who has slept in an honoured grave for upwards 
of two centuries, is resuscitated to be treated only witk more unsparing severity. We proceed now to the discussion of the point in question,-Who discovered North America? The fact, then, that it was JонN $\mathrm{C}_{\text {Aвот }}$ who projected, fitted out, and conducted the expedition by which this discovery was made rests on evidence so conclusive, that it is difficult to imagine how any impartial inquirer can resist its force.

First, There is the original commission or letters-patent in Rymer, vol. xii. p. 595, in which John Cabot is evidently the principal person intrusted with the undertaking. His three sons, Lewis, Sebastian, and Sanchez, are indeed included with him in the patent; but it is allowed on all hands that neither Lewis nor Sanchez accompanied the voyage, and Sebastian, although he undoubtedly went along with his father, could not then have been more than twenty, -an age excluding the idea of his either originating or conducting the enterprise.

Secondly, We have the language of the second patent, dated the $3 \mathrm{~d}$ February, 1498, in which the letters are directed to John Cabot alone, and he is empowered to sail with his ships to the land and isles of late found by the said John, in the king's name and commandment, - a piece of evidence which, even if it stood single and unsupported, appears to be decisive of the question.

Thirdly, We have the inscription under the contemporary portrait of Sebastian Cabot, painted by Holbein, in which he is described as the son of the Venetian, Sir John Cabot, who was the first discoverer of the New Land, "Primi Inventoris Terræ Novæ sub Henrico VII., Angliæ Rege;" and in the

Fourth place, A proof of the same fact is to be found in the inscription by Clement Adams upon the Map of America which he engraved after a drawing of Sebastian Cabot's, and in the lifetime of this navigator. In this inscription, as already more minutely pointed out, * the principal place is given to the father, John Cabot, and the son is mentioned, as it appears to us, not as commanding the ships or having originated the voyage, but simply as accompanying the expedition. 
Having gone thus far, we are now ready to enter upon the investigation of the arguments urged by the biographer in favour of the claim which he has set up for Sebastian as the sole discoverer; and here we may remark, that in the classification of his evidence he has followed a method which is certainly not the best calculated for the manifestation of truth. He first arranges what he denominates the proofs in support of the father; but those which he enumerates first, and which alone he discusses with minute attention, are the weakest that could be selected, and such as no one who carefully weighs them would place much reliance on ; while the unanswerable evidence is brought in last with extreme brevity, and dismissed with scarce any observation.

"The various items of evidence," says he, "which are supposed to establish the prevailing personal agency of John Cabot, may be ranked thus :-

"1. The alleged statement of Robert Fabyan.

" 2 . The language of more recent writers as to the character of the father.

"3. The appearance of his name in the map cut by Clement Adams, and also in the patents.

"As to the first," he continues, "the authority usually referred to is found in Hakluyt, vol. iii. p. 9,- 'A note of Sebastian Cabot's first discoverie of part of the Indies, taken out of the latter part of Robert Fabyan's Chronicle, not hitherto printed, which is in the custodie of M. John Siow, a diligent preserver of antiquities. In the 13 yeere of $K$. Henry the 7 (by meanes of one John Cabot, a Venetian, which made himselfe very expert and cunning in the knowledge of the circuit of the world, and islands of the same, as by a sea-card and other demonstrations reasonable he shewed), the king caused to man and victuall a ship at Bristow, to search for an island which he said he knew well 'was rich, and replenished with great commodities ; which shippe, thus manned and victualled, at the king's costs, divers merchants of London ventured in her small stocks, being in her, as chief patron, the said Venetian. And in the company of the said ship, sailed also out of Bristow, three or foure small ships, fraught with sleight and grosse marchandises, as course cloth, caps, laces, points, and other trifles. 
and so departed from Bristow in the beginning of May, of whom, in this maior's time, returned no tidings."

This is the passage which the author of the Memoir has accused Hakluyt of perverting; and, instead of giving it simply as it was furnished by Stow,--of interpolating the name of John Cabot. Nor is it difficult to see how he was led to make this accusation. It was necessary, in support of his views, to show that this alleged statement of Fabyan contained no allusion to Joln, but actually supported the claim of Sebastian Cabot: but this could not be done if Hakluyt has given it fairly; and in this way the biographer, animated with zeal for his theory, was imperceptibly drawn on to attack the integrity of this writer. Now, before considering so grave an accusation against Hakluyt, we have one introductory remark to make upon this quotation from Fabyan. It is certain that it alludes to the second voyage made to North America by Sebastian Cabot, in the year 1498 , and not to the first, in which that country was discovered. Of this the passage contains internal evidence which is perfectly anclusive. The first voyage took place in the twelfth year of Henry VII. This in the thirteenth. The first voyage was at the sole expense of the adventurers. Of this the king bore the expense. The first voyage could allude to no former discovery. This alludes to an island which had been already discovered. To quote the passage, therefore, as evidence in favour of John Cabot's discovery, which has certainly been done by some modern writers, argues a rapid and superficial examination of its contents. Certainly Hakluyt does not cite it with this view ; but includes it, on the contrary, among those portions of evidence, those testimonies, as he calls them, in which the sole glory of the earliest voyage to North America is given to Sebastian Cabot.* All this may be true, says the memorialist, but it does not exculpate Hakluyt. I do not accuse him of citing the passage as a proof in favour of John Cabot-but of altering it so as to mislead other authors: he has "perverted" the passage, and has suffered the evidence of his "guilty deed" to lie about, so as to furnish the means of his own conviction. Such is the charge advanced against Hakluyt ; and never, we will venture to say, was there a

* Hakluyt's Voyages, edition 1600, vol. iil. p. 4-9, inclusire. Ff 
more unfounded accusation, as will appear when it comeg to be examined, and yet the argument of the biographer is ingenious, and it requires some attention to detect its fallacy.

The object in the whole matter, it will be observed, was twofold ; first, to show that Robert Fabyan, a contemporary author, ascribes the discovery of North America to Sebastian, and not to John Cabot; and, secondly, to prove that Hakluyt has been guilty of dishonestly perverting the passage from Fabyan communicated to him by Stow the antiquary. How then does he accomplish this? In the first place, he goes to the earliest work of Hakluyt, published in 1582, where this writer gives for the first time the following note as to the discovery, which we quote vcrbatim from the work itself, now lying on our table :-

"A Note of Sebastian Gabote's Voyage of Discoverie, taken out of an old Chronicle written by RoBert FABIAN, some time Alderman of London, which is in the custodie of Jонм STow, citizen, a diligent searcher and preserver of antiquities.

In the 13 Thrs yeere the king (by means of a Venetian yeare of King Henrie which made himselfe very expert and cunning the VII. in knowledge of the circuite of the worlde, and 1498. islands of the same, as by a carde and other demonstrations reasonable hee shewed) caused to man and victuall a shippe at Bristowe, to searche for an ilande, whiche hee saide hee knewe well was riche, and replenished with riche commodities. Which ship, thus manned and victualled at the kinge's costs, divers merchants of London ventured in her small stockes, being in her, as chiefe patrone, the said Venetian, and in the companie of the said shippe, Bristow. sayled also out of Bristowe three or foure small ships fraught with sleight and grosse merchan-
dizes, as course cloth, caps, iaces, points, and other trifles, $\mathrm{Wm}$. Pur- and so departed from Bristowe in the beginning chas, Maior of May, of whom, in this Maior's time, returned of London. no tidings."

Having given this quotation from Hakluyt's publication of 1582 , the writer of the life next turns to the larger work of the same author, published in 1589, and he discovers 
that he has added to the sentence, as it stood in 1582, the words "one John Cabot." The passage in the narrative of 1589 stands thus :- "In the 13 yeere of King Henrie the VII. by means of one John Cabot, a Venetian, which made himself very expert," \&c., the rest of the sentence being the same as in 1582. Here then, says he, is manifest interpolation and dishonesty; the original passage from Fabyan has been altered; Hakluyt, in 1589, does not give it in the same turms as in 1582. Before, however, arriving at so strong and uncharitable a conclusion, it must strike every reader that the original passage, either as it stands in Fabyan, or as it stood in the extract furnished by Stow from Fabyan, ought to be carefully examined. Till the passage, as it is given by Hakluyt, is compared with one or other of these, it is perfectly evident that no charge of alteration or interpolation can be made good against him. Now, the original chronicle of Fabyan, from which Stow took the passage, is lost-and the biographer does not pretend that he has discovered in the manuscripts of Hakluyt the original passage, as extracted by Stow, and sent to this writerbut he endeavours to supply it in a very singular manner. In speaking of Hakluyt's alleged perversion of the passage, as sent by Stow, he observes:- "Fortunately, we are not left to mere conjecture. In 1605 appeared Stow's own 'Annals.' The simplicity and good faith of this writer are so well known, as well as his intense reverence for whatever bore the stamp of antiquity, that we have no fear of his having committed what in his eyes would have been sacrilege, by changing one syllable of the original. Let it be remembered, then, that Hakluyt relies exclusively on what he obtained from Stow ; and in reading the following passage from the Annals, we find what doubtless passed into Hakluyt's hands before it was submitted to his perilous correction. It occurs at p. 804 of the edition of 1605 , and at p. 483 of that of 1631. "This year one Sebastian Gaboto, a Genoa's sonne borne in Bristol, professing himself to be expert in the knowledge of the circuit of the world, and islands of the same, as by his charts and other reasonable demonstrations he shewed, caused the king to man and victual a ship,' \&c. The rest corresponds with the passage in Hakluyt. * * * Thus," continues the biographer, 
"we have the best evidence that the contemporary writer, whoever he may have been, made not the slightest allusion to the father. Bacon, Speed, Thuanus, \&c. all furnish the same statement."*

Such is the passage from the Memoir of Cabot; and thus it appears that the whole of this attack upon Hakluyt rests upon a fact which the biographer imagines he has proved, but which in truth is nothing else than a piece of the merest and the most vague presumption-namely, that Stow furnished Hakluyt, in 1582, with an extract from Fabyan, which, when he himself proceeded, about eighteen years after, to compile his Annals from a long list of writers, whose names he has given us in his prefatory. pages, he so scrupulously copied, that we are entitled to take it as it stands in the said Annals, and argue upon it as the identical passage contained in the lost chronicle of Fabyan.

But this is not merely gratuitous assumption. There is, we think, strong evidence to show that Stow, in composing his various works, did not, upon the point in question,the discovery of America,-consult the manuscript of Fabyan, although he affirms it to be in his possession, but in the multiplicity of his authorities had overlooked it altogether. The first Summary of Chronicles was published by this industrious antiquary in 1565 . A new edition was given in 1573, and again another edition in 1598. His excellent work entitled a Survey of London and Westminster was also published in 1598; and it is a remarkable circumstance, and one which militates strongly against the hypothesis of the biographer, that although in the list of his authorities prefixed to the edition of his Chronicles in 1573, and to the Survey of London, there is express mention of the manuscript by Fabyan, still, in neither of these works is there any allusion made, which we can discover, to the voyages of the Cabots, or the discovery of America. His work entitled Flores Historiarum, or Annals of England, was published in 1600 , and here, for the first time, is the passage regarding the voyage to America introduced; in which, as we have already seen, Sebastian Cabot is called "a Genoa's son." But it is to be recollected that Robert Fabyan was a contemporary of Sebastian Cabot, 
that he was a rich merchant and alderman of London; and the probability is, that he was either personally acquainted with so illustrious a navigator, or at least enjoyed the best opportunities of rendering himself master of his history. It appears to us, therefore, exceedingly improbable that Fabyan should have fallen into the error of describing Sebastian Cabot as a Genoese's son, instead of the son of a Venetian. Now, it is a singular circumstance, that in the Chronicle of Thomas Lanquette, a work which Stow also mentions as in his possession, Sebastian is described as the son of a Genoese, and the discoverer of a part of the West Indies, ${ }^{*}$ and this induces us to conjecture that the passage in question was taken by Stow, not from Fabyan's Chronicle, but from that work. Down to 1598, he does not appear to have examined Fabyan's treatise upon the subject of America, or Cabot; and becoming old (he was now in his seventy-sixth year), and failing in his memory, it appears extremely probable that he had contented himself with a reference to the volume of Lanquette.

So far, therefore, from admitting the fact which has been hastily, and without any sufficient ground, assumed by the biographer, that the passage in Stow's Annals regarding Sebastian Cabot may be considered the very extract from Fabyan communicated to Hakluyt, we contend that a minute examination of Stow's historical labours proves that, in composing his Annals, he had omitted to consult the Chronicle of Fabyan, and had copied some less authentic writer-probably the Chronicle of Lanquette. What follows from this?-First, the whole elaborate accusation of guilty perversion of the extract from $\mathrm{F}$ abyan, so unceremoniously advanced against Hakluyt, falls completely to the ground. Secondly, the biographer's supposed passage from Fabyan, a contemporary, turns out to be nothing more than a quotation from Stow; and consequently, the assertion that the former has described Sebastian Cabot as the sole projector and executor of the voyage in which North America was discovered, is perfectly unwarrantable. The original manuscript of Fabyan, as we have already

* Barrett's Bristol, p. 185, 173. I take it for granted that this author must have seen the passage which he quotes; but in the only edition of Lanquette's Chronicle which I have had an opportunity of examining there is no such passage. 
stated, is lost; the original extract from it furnished by Stow to Hakluyt is also lost ; and without a minute examination of these two documents, the biographer was not entitled to wound the fair reputation of this excellent writer, to whom the history of naval discovery is under so many obligations, by charges without proof, and innuendoes arising mainly out of the errors which he himself has committed.

But the biographer will perhaps contend that he has at least made out one fact against Hakluyt-namely, that in 1589 he altered the passage from the form in which he gave it in 1582 ; and is not this, says he, a dishonest and guilty deed? To this we answer, - - and we think it impossible for him to controvert the assertion,--that, admitting the fact, there is no guilt or dishonesty in the case. The vitiation of the text imputed here to Hakluyt may be considered either as a perversion of the real truth, historically considered, or of the individual passage, or of both.

First, then, it is to be remarked, that Hakluyt cannot be accused of dishonesty, historically speaking, because in the passages in question he has stated nothing but the truth. It has been already proved that the extract communicated by Stow relates solely to the second voyage of 1498, planned and fitted out by John Cabot the Venetian, and conducted afterward by his son Sebastian; and the alteration of the note, from the words "a Venetian," used in 1582, to the words "one John Cabot, a Venetian," used in 1589 , only makes it speak with more clearness and accuracy. But, in the second place, Hakluyt, says the biographer, has perverted and altered a quotation. There might be some appearance of plausibility in this accusation, if Hakluyt had given the passage in dispute as a quotation, and had thus bound himself down to the common usage which compels an author in such a case to insert it word for word. But he does not do so. He warns the reader that he is perusing, not a quotation, but a " note made up by him from an extract communicated by Stow, and taken out of the latter part of Robert Fabyan's Chronicle, not hitherto printed ;" and having done so, he considered himself at liberty to correct that note, by inserting in it any additional information which he had acquired. In 1582, he thought that the wurds, "a Genoa's son, born in Bristol," could not apply to Sebastian Cabot, with whom they were 
coupled, and he inserts the words, "a Venetian," dropping the name altogether. In 1589 , he had probably become acquainted with the second patent, which ascribed the plan of the expedition solely to John Cabot; and he therefore added to his note the words, "John Cabot, a Venetian," where he speaks of the person who had caused the king to man and victual a ship. Even, therefore, if we were to admit, which we do not, that a discrepancy had been made out between the passages in Hakluyt and the real extract from the Chronicle of Robert Fabyan, we should be entitled to repel any accusations against his honesty, founded upon a basis so extremely erroneous.

The memorialist now comes to the consideration of the proof as to the "personal agency of the father in the discovery of North America, derived from the inscription on the map cut by Clement Adams, which Hakluyt states is to be seen in her majesty's Privy Gallery at Westminster, and in many other ancient merchants' houses."* And here he commences his examination by another unfair innuendo against this writer. "We approach the statement of Hakluyt," says he, "with a conviction that he would not hesitate for a moment to interpolate the name of John Cabot, if he thought that thereby was secured a better correspondence with the original patent." I have convicted him (it is thus he argues) of interpolating the quotation furnished by Stow from Fabyan, and there is a strong presumption he would not hesitate to alter the inscription also. "It would, certainly," he remarks, "require less audacity to associate here the name of the father, as it is found in the patent, than to do that of which Hakluyt has already been convicted." $\dagger$ To this indirect insiruation it may be calmly replied, that, as the first attempt to affix guilt upon Hakluyt has been shown to be a total failure, the inscription ought to be received from his hands with perfect confidence that we read it in his work exactly as it was copied by him from the original map of Sebastian Cabot, cut by Clement Adams. From the manner in which it is given, first in the original Latin, and then translated, it professes to be an exact quotation; and even were Hakluyt as guilty a person as the biographer represents him, it might be contended

* See the proof stated. Supra, p. 16

† Memoir of Cabot, p. 48. 
that he would have paused before he committed an act of interpolation, of which the original in the Queen's Gallery, and in many ancient merchants' houses, must have instantly convicted him.

But to proceed. Having thus prepared us to expect an audacious alteration, the biographer endeavours to show that those persons who had seen Sebastian Cabot's charts and maps, introduce no allusion to the father, and he leaves the reader to make the inevitable inference against Hakluyt's honesty. This writer has quoted an inscription on Sebastian Cabot's map, which attributes the discovery to John Cabot. But Sir Humphrey Gilbert, who had seen Sebastian's charts, makes no allusion to the father; and Richard Willes, who speaks familiarly of the map of this navigator, does not mention John; therefore it is left to the reader silently to infer that Hakluyt may have interpolated the name of the father. A plain statement of the fact will put all this down in an instant:- Hakluyt has narrated in the clearest terms that the map to which he alludes, and from which he copies the inscription, was engraved by Clement Adams; and the terms of the inscription show that it (the inscription) was added by the artist. Sir Humphrey Gilbert, on the contrary, just as clearly states, that the documents to which he alludes, are "charts of Sebastian Cabot, which are to be seen in the queen majesty's Privy Gallery at Whitehall,"-evidently meaning the original charts drawn by this seaman, and presented to the queen ;* and Willes does not inention the engraved map at all, but speaks of a table of Sebastian Cabot, which the father of I.ady Warwick had at Cheynies. $\dagger$ 'The argument, therefore, or rather the unfavourable inference created in the mind of the reader by the biographer, which derives its force from the supposition that Sir Humphrey Gilbert and Richard Willes refer to the same document as Hakluyt, namely, the engraved map by Clement Adams, falls completely to the ground. If there had been any account of the first discovery on the charts alluded to by Gilbert, and the "table" mentioned by Willes, and in this account the father's name had not appeared, there might be some pre-

* Hakluyt, vol. iii. p. 16.

t History of Travel in the West and East Indies, p. 232. Hakluyt, vol. lii. p. 25,26 . 
sumption against the elder Cabot; but the writer of the Memoir does not pretend there was any such account or inscription on the charts and the table; and to infer, from the silence of Gilbert and Willes, either that Hakluyt had altered the inscription, or that John Cabot could not have been the original discoverer, is a remarkable instance of vague and inconclusive reasoning.

This is the proper place to notice an extraordinary error, or rather series of errors, fallen into by the biographer, regarding this same "extract." It is described by Hakluyt as an "extract taken out of the map of Sebastian Cabot, cut by Clement Adams, concerning his discovery of the West Indies, which is to be seen in her majestie's Privy Gallery at Westminster, and in many other ancient merchants' houses." Clearer words, one would think, could scarcely be employed to express the fact that a map engraved by Adams hung in the Privy Gallery at Westminster, from which Hakluyt, who was much about court, copied the extract or inseription which he has given at p. 6. Yet the biographer has committed the singular blunder of supposing that it was the extract from the map, and not the map itself, which was hung up in the Privy Gallery at Westminster, and that it may be inferred that Hakluyt had never seen the original map. "From the stress," says he, "laid by Hakluyt and Purchas on the extract hung up in the Privy Gallery at Whitehall, we may infer that they had never seen the original map." ${ }^{*}$ In this sentence there occurs a second error, in imagining that both Hakluyt and Purchas refer to the same document. The allusion by Purchas, $\dagger$ however, is to one totally different. This author refers, not to any extract taken from the map cut by Clement Adams, but to "the words of a great map in his majesty's Privy Gallery, of which Sebastian Cabot is often therein called the author, and his picture is therein drawn," which map, Purchas adds in the margin, "some say was taken out of Sir Sebastian Cabot's map by Clement Adams ;" a sentence proving, beyond a doubt, that these writers allude to different works,- Hakluyt to the map of Clement Adams, Purchas to a later one, supposed by some authors to be copied from it. Lastly, in a succeeding sentence, $\ddagger$ the author of

* Memoir of Cabot, p. 52.

$\ddagger$ Memoir of Cabot, p. 52 .

f Purchas, vol. iii. p. 807. 
the Memoir, when he hazards the conjecture that the map by Adams was executed after Cabot's death, and therefore without any communication from him, again widely errs from the truth; for had he consulted Purchas he would have found that the map by Adams was published in 1549.* Thus, in a sentence which occupies the short space of seven lines, three errors, and these of notrivial importance, are committed. The first error is material ; because it inevitably leads the reader to believe that Hakluyt is only giving an extract from an extract, whereas he is giving an extract from an original which he had seen. The second error is also important; because it would induce us to infer that Purchas and Hakluyt resolve into one and the same witness, whereas Purchas quotes a separate and additional testimony; for, it is to be observed, that, on a map engraved probably some time in the reign of James VI., there was copied the same inscription as in the early map in 1549 ; from which we are entitled to conclude, that in the interval nothing had transpired to invalidate the truth of the inscription. Lastly, the third error is most material of all ; because its effect is to lead us to consider the Latin inscription copied by Hakluyt from the map by Clement Adams as of little or no weight in evidence, instead of which it is, as has already been shown in the text, $\dagger$ as nearly as possible equivalent to a declaration of Sebastian Cabot himself.

The laboured endeavour to get rid of the overpowering evidence of the inscription, by impeaching the accuracy and integrity of the copy furnished by Hakluyt, is thus singularly unsuccessful; and having failed in this point, the author of the Life of Cabot passes over altogether the proof which it contains. This, we think, may be taken for a silent admission that, if correctly given, it proves that John Cabot was the discoverer; and we shall not fatigue the reader by a repetition of the arguments given in the text, only reminding him that it is there shown that the inscription was written, probably from the information communicated, either by Sebastian or by some persons who accompanied the voyagre, and that the map where it occurs must have been often seen by this navigator.

In his examination of the proofs of the personal agency

* Purchas, vol. iii. p. 807.

† Supra, p. 17 
of John Cabot, the biographer now arrives at the appearance of his name in the letters-patent granted by the king. These interesting documents, from their priority of date and the importance of their evidence, every impartial in quirer would, we think, have ranked first; but he at once assigns them the last place, and passes them very lightly over. With the substance of these royal letters the reader is already acquainted; ${ }^{*}$ and it is here sufficient to repeat that the commission, in virt'ue of which the first voyage of 1497 was undertaken, during which North America was discovered, is granted to John Cabot and his three sons, while the second commission of $\mathrm{J} 498$ is not only granted to John Cabot alone, but, alluding to the voyage already made, describes him as the sole discoverer, "giving him permission to lead his ships to the land and isles of late found by the said John in the king's name, and by his command." To escape from this clear and unanswerable assertion in a document whose authenticity is higher than that of any other which can be produced, the memorialist, trembling for his favourite Sebastian, is driven to some very desperate and amusing expedients. He first asserts, that the appearance of the father's name in the first commission or patent does not prove that he embarked in either of the expeditions. Now, undoubtedly, if the first patent stood alone, the father's name in that deed would not conclusively prove that he conducted the first voyage, although a strong presumption that he did so might fairly be founded upon it; but it is evident the two patents, in estimating the evidence, must be taken together, and how does the biographer get rid of the second, which, in language neither to be evaded nor misunderstood, distinctly asserts the fact of the discovery by the said John, and by John only; for no other name but that of the father appears in the deed? The extraordinary theory by which he attempts to elude its evidence will best be given in his own words. "The second patent," says he, " is to the fathe alone. If we seek a reason for this departure from the original arrangement, it may be conjectured that some of the sons chose to give a different direction to a parental advance and their personal exertions; and that the head of the fumily

* Supra, p. 15, 18. 
thought fit to retain subject to his own discretionary dis posal the proposed investment of his remaining capital. It is said that one of the sons settled at Venice, and the other at Genoa. The recital of the discovery by the father would of course be stated, under the circumstances, as the consideration of the second patent in his favour. Another reason for the introduction of the father's name concurrently at first with his sons', and afterward exclusively, may perhaps be found in the wary character of the king, whose own pecuniary interests were involved in the result. He might be anxious thus to secure the responsibility of the wealthy Venetian for the faithful execution of the terms of the patent, and finally think it better to have him solely named rather than commit powers, on their face assignable, to young men who had no stake in the country, and who were not likely to make it even a fixed place of residence. On the whole, there may at least be a doubt whether the father really accompanied the expedition." is surely quite unnecessary to attempt a serious reply to this singular passage, which, advancing from one step of an improbable and unsupported hypothesis to another, lands the reader at last in that conclusion of outrageous skepticism which has just been quoted. The words of the second commission state a simple fact, "that the land and isles were discovered by John Cabot." The biographer, in reply, first talks discursively and at some length on the motives which induced the sons, Lewis, Sanchez, and Sebastian, to withdraw a capital which there is no proof they ever advanced,- subjects of little moment,- and he then at once gets rid of the stubborn fact, that John Cabot is named as the "sole discoverer," by the incidental remark, that this would, of course, be stated as the ground of the second patent,- - a species of reply which irresistibly reminds us of the celebrated mode of getting rid of any difficulty "by a concatenation." We leave the reader to form his own conclusion from the words of the commission, with no anxiety as to the result.

It is asserted that Hakluyt is guilty of perversion when he describes John Cabot as "very expert and cunning in the knowledge of the circuit of the world, and islands of the 
same, as by a sea-card, and other demonstrations reasonable, he shewed;"* and in the same breath the biographer proceeds to arraign Campbell, Macpherson, and Barrow of folly, because they speak of him as a scientific and able seaman, there being no proof that he was any thing else than a merchant who dwelt in England.t Now when Hakluyt, in a writing of unquestionable authenticity (the first royal commission just quoted), found John Cabot intrusted with the command of a squadron of five ships, which was empowered to sail on a voyage of discovery to all countries and seas of the east, west, and north, he certainly cannot be accused of having committed any grievous infringement upon truth or probability when he described him as a seaman; and when, in another document of almost equal authority (the inscription on the maj) by Clement Adams), he observed it stated that he, along with his son Sebastian, were the first who discovered North America, are we to be told that he was guilty of excessive exaggeration, when he drew the inference which every discerning and impartial mind would be inclined to derive from the same facts, that the author of such a discovery must have been an excellent navigator and cosmographer? Nor is it a fair mode of reasoning to accuse Campbell and Barrow as guilty of a thousand absurdities, when they describe John Cabot as an " accomplished seaman, a shilful pilot, or an intrepid navigator." $\ddagger$ These writers, it is to be recollected, had before them the letters-patent in Rymer, and the inscription by Adams, instruments which had in no way been perverted; and from an examination of these they arrived at the con. clusion, to which every reader is inevitably led, that he who possessed the inventive mind to plan this new course to India by the north-west, who had in person commanded the expedition and successfully achieved the discovery, must have been, both as a practical and a scientific navigator, a man of no ordinary character and acquirements.

It is difficult, within the limits to which we must confine these remarks, to reply to the various accusations against Hakluyt which are scattered throughout the pages of this

* Hakluyt, vol. iii. p. 9.

† Ivid. p. 46, 50, 51 .
† Memoir of Cabot, p. 46, 47, 50, 51 .

G g 
Memoir; besides, we do not profess to write a full vindica tion of that excellent author. $\mathrm{He}$ is arraigned of ignorance and carelessness as a translator, of a want of integrity in regard to the sense of his original, and of appropriating to himself passages from other authors without acknowledgment. The gravest accusation, that of wilfully altering the sense of his original, has been satisfactorily answered already ; but we venture to say that few who are acquainted with his amusing and instructive volumes will not be astonished at the charge of plagiarism. A conscientious and even tedious scrupulosity in giving the names of every individual from whom he has derived his information is one of the most striking features of his work. The third volume of the second edition of his voyages happens to be now on the table before us : it consists of about 158 separate documents, and we will venture to say, that of these there is not one upon which the biographer can support a charge of any thing approaching to serious and premeditated plagia rism; not one in which, if the author's name is known, it is not anxiously mentioned; or, if it is unknown, where the anonymous paper is not given in such a way that it cannot possibly be attributed to the compiler himself. Even the two instances in this volume quoted against him by the biographer do not in fair reasoning form an exception.

No one who has read Hakluyt's preface will be disposed to think with severity of the slight alterations which, with the honest intention of presenting the whole truth before his reader, he has occasionally introduced into the abstracts, notes, and translations, which form the great body of his work. His earnest desire, as he himself declares, "was to adjust the displaced and scattered limbs, as well of ancient and late voyages by sea as of travels by land, and traffic of merchandise by both, into one regular body; restoring each divided and dislocated member to its natural order and symmetry, and by the help of geography and chronology, the sun and moon, or right and left eye of all history, referring each particular narration to its due time and place." That in accomplishing this laudable object he has sometimes used rather undue liberties with his documents, may be admitted; but even in the most remarkable of these instances of alleged mistranslation and interpolation which the biogra- 
pher has brought against him, the passages are first accurately given in the original language, a mode of proceeding which completely establishes the honesty of his intentions. It is vain to accuse of fraudulcnt interpolation a writer who first warns the reader that he must be prepared to find some of the translations of the documents which he has presented partially transposed, and corrected by the help of geography and chronology, and who carefully quotes, in the same page, the passages in the original, before he presents them in the shape which he believes consistent with truth. If this be fraud, it possesses a very singular character; it is fraud which courts detection; it is forgery, studiously placing in the hands of all readers the documents by which its iniquity may be traced and established.

With regard to the attack made upon this writer for his ignorance and mistranslation, the author of the Life of Cabot, we think, in considering Hakluyt's voluminous labours, consisting of three folio volumes, might have been disposed to pardon a few inaccuracies of this nature. They will insinuate themselves, however anxiuus we may be to avoid them, into all human productions; and he who has spent most time in works requiring multifarious research, and the painful examination of ancient authorities, will be the most disposed to view with lenient eyes the errors of such as are similarly occupied. If the biographer will turn to his own Memoir (p. 240) he will find in Pasquiligi's description of the captives the following sentence: "Hanno signata la faza in modo de Indiani : chi da vi., chi da viii., chi da manco segni." Their faces they have punctured like Indians', some with six, some with eight, some with fewer marks. In the Memoir, it is thus translated, "They puncture the face, like the Indians, exhibiting six, eight, or even more marks." Do not let the biographer imagine that we have quoted this erroneous version of a very simple passage with the view of accusing him of ignorance, or that there is the slightest intention of insinuating that he did not know that the four words "chi da manco segni" meant "some with fewer marks." The oversight is pointed out as an example of the occasional mistranslations or mistakes into which, with every desire to be accurate, even a well-informed writer will occasionally fall, that he may be inclined to extend to the labours of others that charity of criticism with 
which he would wish that every liberal mind should regard his own.*

The author of the Life of Cabot was perfectly entitled to maintain the theory that Sebastian, the son, and not John Cabot, the father, was the discoverer of North America ; but he was not entitled to adopt, what we must denominate the disingenuous method of making an impression upon the reader's mind by silently dropping the name of the latter out of passages where, if he had stated the whole truth, he ought to have mentioned both. Thus, at page 174 we find this remark: "At his return [Sebastian] Cabot settled in Bristol, * * * * * fifty-three years after the date of his first commission from Henry VII." Again, page 222 , we find this notice: "Sixty-one years had now elapsed since the date of the first commission from Henry VII. to Sebastian Cabot, and the powers of nature must have been absolutely wearied out." Again, page 235, we have another more glaring example of this determination to keep the father entirely out of view : "The bare mention of these dates will establish the impossibility that he could have been ignorant of the great discoveries of Cabot [it is Sebastian he is speaking of ], which, commencing at the point seen on the 24th June, 1497, had extended over the 'londe and isle' recited in the second patent." In the first and second of these sentences John Cabot's name is entirely suppressed, although the commission spoken of was directed to him, along with his three sons; and in the last, the entire merit of the discovery is ascribed to Sebastian, at the moment the biographer is quoting the words of the second commission, which positively attributes it to John.

Allusion has already been shortly made to the "evidence" contained in the inscription upon an ancient portrait of Sebastian Cabot ; but we must be allowed, for a moment, to add a few words upon this proof, which is very important and conclusive. There is now in existence a portrait of this navigator, by Holbein, for a minute history of which we refer the reader to the Appendix to the Memoir of Cabot. +

* In the same passage from Pasquiligi, another oversight occurs: "Nela terra loro non hanno ferro: ma fanno cortelli de alcune pietre." Memoir of Cabot, p. 240. "In their country they do not possess iron, but they make knives of particular kinds of stones." 'Ihe biographer translates cortelli swords.

t Memoir of Cabot, Appendix, Letter F. p. 323. 
It is sufficient for our purpose to remark, that it is acknowledged to be an original, for which Sebastian sat to the artist, and which, in the time of Purchas, hung in the Privy Gallery at Whitehall. Upon this picture is the following inscription: "Efligies Seb. Caboti Angli, filii Johaunis Caboti Veneti Militis Aurati, Primi Inventoris Terræ Novæ sub Henrico VII. Angliæ Rege." It is evident, by the common rules of grammatical construction, that the words Militis Aurati, Primi Inventoris Terræ Novæ sub Henrico VII. Angliæ Rege, apply exclusively to John Cabot; and if so, they contain a positive assertion that John was the first discoverer of North America. Now, the authenticity of the picture being undoubted, the inscription furnishes as convincing a piece of evidence as could well be conceived. And again, it may be fairly argued, that the circumstance of the words Militis Aurati being found united with the name of John Cabot, by which it is proved that the king had conferred on him, and not on Sebastian, the honour of knighthood, affords the strongest presumption that it was John who was the original discoverer.

This remark leads us, in the last place, to expose an extraordinary series of errors committed by the biographer, in relation to this Latin inscription on the picture. He has accused Dr. Henry, Dr. Campbell, and the authors of the Biographia Britannica of an absurd misconception, in imagining that the words Militis Aurati indicate that John Cabot had been knighted. But it is justice to let him speak for himself. He first demonstrates that the words Miles Auratus cannot possibly apply to the son Sebastian, after which he proceeds thus :- "The point being thus clear with regard to the son, other writers have assumed, as a matter of course, that the distinction (of knighthood) must have been conferred on John Cabot." "Accordingly, Campbell, in his Lives of the Admirals, has an article entitled Sir John Cabot. Dr. Henry informs us, in his History of Britain, vol. vi. p. 618, that John Cabot was graciously received and knighted on his return, and the same statement is repeated in the Biographia Britannica." "To the utter confusion," he continues, "of all these grave authorities, a moment's consideration will show that the words relied on do in themselves prove that knighthood had not been conferred. It is scarcely necessary to follow up this sug- 
gestion, by stating, that in reference to one who had received that honour, they would have been, not Militis Aurati, but Equitis Aurati. Though the term Milcs is sometimes applied in old documents even to peers, yet, as a popular designation, the language of the inscription negatives the idea of knighthood. In the very works immediately connected with the subject of the present volume, the appropriate phrase perpetually occurs. Thus, Eques Auratus is used to designate Sir Humphrey Gilbert (Hakluyt, vol. iii. p. 137); Sir Hugh Willoughby, ib. p. 142 ; Sir Martin Frobisher, ib. p. 142; Sir Francis Drake, ib. p. 143. In the dedication of ILok's translation of Peter Martyr, it is in like manner used, and we see it at this moment on the 'Effigies' of Sir Walter Raleigh, prefixed to the first edition of his History of the World. It will probably be deemed very superfluous to refer to Selden's Titles of Honour (p. 830) for a confirmation of what has been stated. The weight of censure must fall on Purchas, who was originally guilty of the blunder."*

One would have thought that the writer must have been very sure of the ground on which he stood before he venEured to assume so lofty and decisive a tone, - and yet we are altogether at a loss for expressions which may mark courteously, and yet strongly, the combination of error, ignorance, and absurdity presented by this extraordinary sentence. He first argues, that the words Miles Auratus are never used to denote a knight; and, secondly, that where they are used, they "do in themselves prove that knighthood had not been conferred." Now, fortunately, the biographer allows that Sir Humphrey Gilbert was a knight, indeed he is one of his own examples of Equites Aurati. Keeping this in mind, we request him to turn to Holland's celebrated and well-known work, the Heroologia Anglix, containing the engraved portraits of the most eminent Engiish warriors, navigators, statesmen, and ecclesiastical reformers, who flourished in England from 1500 to 1620. He will there find, at p. 65, vol. i., a beautiful head of Sir Humphrey Gilbert, and around it the following inscription, - "Humfridus Gilbertus, Miles Auratus." Do these words prove here that knighthood had not been conferred?

* Memoir of Cabot, p. 183. 
Again, we beg him to turn to another engraving in the same work, the portrait of the celebrated Sir Richard Grenville, of whose knighthood there is not the smallest doubt. It will be found at page 85 of the first volume of Holland's work, and it is thus inscribed around the margin,--" $\mathrm{R}_{\mathrm{ICH}}$ Ardus Grenvilus, Mil. Aur. :" (Miles Auratus.) But the biographer has quoted the famous Sir Francis Drake, as illustrating his argument. He points triumphantly to him as an undoubted knight, being styled Eques Auratus, and to whor, therefore, the words Miles Auratus could not possibly be applied. Once more, we beg him to turn to the Heroologia, vol. i. page 105 . He will there see a striking portrait of Drake, with his hand resting on the globe, and these words round the margin of the print,-- "F Fanciscug Drake, Miles Auratus." One other example may be given of the common use of those words to denote knighthood, which, according to the positive assertion of our author, are never found together, and which, if used, prove that this honour had not been conferred. It is the first sentence in Holland's Life of Sir John Harrington, Heroologia, page 133. "Joannes Harington filius natu maximus Clarissimi Mititis Jacobi Haringtoni de Exton, in Comitatu Rutlandie, Equestri seu Militis Aurati dignitate multis abhinc annis a beatissimæ memoriæ Regina Elizabetha insignitus fuit." It need hardly be pointed out to the intelligent reader, that this brief sentence of four lines, in its use of the word Miles by itself to denote knighthood, and Miles Auratus, as synonymous with the terms dignitas Equestris, overturns the whole argument of the biographer, who not only contends that the expression Miles Auratus is neve: used as descriptive of knighthood, but that, except in ancient deeds, the single word Miles never occurs. Had he taken the trouble to consult any friend who possessed even a superficial acquaintance with the language in which the inscription was written, he must have discovered that the words Eques Auratus, Miles Auratus, Eques by itself, and Miles by itself, are used indiscriminately in modern Latin to denote knighthood; and that the "absurd misconception" imputed to others existed nowhere but in his own ideas.

But even had we not been able to quote such unanswerable instances as Humphrey, Grenville, Drake, and Haj- 
rington, it is singular that it should not have occurred to this writer that the words Miles Auratus upon John Cabot's portrait must necessarily have had some meaning, - that they must either be literally translated, or be understood to express knighthood. Now this last he will not allow them to denote; and the only meaning he affixes to them is, that they "negative the idea of knighthood, and prove that such an honour had not been conferred." We are driven then to a literal interpretation ; and it is impossible for him, according to the principle he has laid down, to give any other translation than this: "The portrait of Sebastian Cabot, Englishman, son of John Cabot the Venetian, a golden soldier, but by no means a knight." Such is the singular and amusing interpretation which, had he weighed his own assertion for a moment, or had he exerted that spirit of diligent, accurate, and extensive research (we are using his own words) to which he lays claim, ${ }^{*}$ the biographer must have found it necessary to adopt. These various errors have been pointed out with no other feeling than a desire of showing the recklessness of the attack upon Campbell, Henry, and the authors of the Biographia Britannica. It is difficult, indeed, to repress a smile when we compare the bitterness and severity of the criticism with the extreme ignorance of the critic ; and in taking leave of this subject, we may be permitted to hope that the recollection of his chapter on the words Miles Auratus will induce the champion of Sebastian Cabot to revise his Latin, and to be more lenient to the real or supposed mistakes of his predecessors and contemporaries.

It has been shown, we trust, to the satisfaction of every one who will impartially weigh the evidence, that John Cabot was the discoverer of North America; and it is satisfactory to find that all that may be called the contemporary proofs,- the first commission in Rymer, the brief narrative on the map by Clement, the words of the second commission, and the inscription on the picture,-confirm the conclusion that this Venetian was entitled to the honour. Before, however, concluding these remarks, we may add a single word on the testimony of later authc is. Fabyan, or the contemporary writer, for he is spoket of under both

- Introduction to Memoir of Cabot, p. I. 
denominations, Bacon, De Thou, and Speed, are all cited by the biographer as exclusively in favour of the title of Sebastian. "We have the best evidence," says he (p. 44), " that the contemporary writer, whoever he may have been, made not the slightest allusion to the father. Bacon, Speed, Thuanus, \&c. all furnish the same statement." Now, with regard to Fabyan, in his printed Chronicle there is no allusion, either to the original Jiseovery on the 24th June, I497, or to the subsequent voyige of Sebastian Cabot in 1498; and as to the supposed manuscript Chronicle which is stated by Stow to have been in his possession, it appears to lave perished, and we have no mode of ascertaining its import, except through the note of Hakluyt, which, as far as it goes, is nowise against the claim of John Cabot. Nay, even granting that (to the contrary of which we have strong proof) in Stow's Chronicle, published in 1605, occurs the very passage of the lost manuscript of Fabyan, and that in this passage Sebastian Cabot, a Genoa's son, born in Bristol, is alone mentioned ; still the reader is already aware of the conclusive answer, namely, that the passage relates, not to the first voyage of 1497 , but to the second voyage of 1498, of which all are agreed that Sebastian Cabot had the command. But another evidence in favour of Sebastian as the original discoverer is said to be found in Lord Bacon's Life of Henry VII. We can scarcely persuade ourselves that any one who makes this assertion can have attentively studied the remark in question, so evidently does it allude, we think, where it mentions Sebastian, to the second voyage of 1498 , and not to the original voyage of 1497 . That Bacon was aware this was not the first discovery, and that he had a vague knwwledge of a prior voyage, in which the continent of America was originally found out, is evident from this sentence: "And there had been before that time a discovery of some lands, which they took to be islands, and were, indeed, the continent of America towards the north-west." Again, as if anxious to warn the reader as to there having been a prior discovery, he says, "But this Gabato bearing the king in hand that he would find out an island endued with rich commodities, procured him to man and victual a ship at Bristol, for the discovery of that island, with whom ventured also three small ships of London merchants, fraught with some gross and slight wares, 
fit for commerce with barbarous people." "It is evident that Lord Bacon is here making use of the passage in Stow, employing, with some slight alterations, its very words. So far, however, from containing a proof that the merit of the original discovery belongs to Sebastian, it warns the reader that the continent had already been found in some prior voyage, although no name is given, and the date is left uncertain. The observation of the biographer, therefore, that Bacon makes no allusion to the father, is literally correct; but the inference drawn from it, that therefore Bacon's testimony goes to support the claim of Sebastian as the original discoverer, is completely excluded when the passage comes to be narrowly examined.

As to De Thou, this great writer, so far as we have looked through his voluminous historical work, contains no passage upon the subject of either voyage; and the same observation applies to such elitims of Grafton, Holinshed, Hall, and Harding as we have had an opportunity of consulting. It has been already remarked that the sentence quoted from Stow, which the biographer erroneously conceives to offer a proof that Sebastian had the sole charge of the voyage of 1497 , in which the discovery was made, relates solely to the second voyage of $1498 . \dagger$ With regard to Speed, whom he also quotes as, along with Bacon and De Thou, making no allusion to the father, the same answer strictly applies, - - the only voyage of which he takes notice being the second, in 1498, as is distinctly fixed by his observation that it took place after the apprehension of Perkin Warbeck.f It is very evident, however, that the biographer was bound to show that Bacon, Stow, and Speed had given an account of the first voyage of 1497 , in which the discovery was made, and in that account had introduced no allusion to the father, before he was entitled, from their omission, to draw any argument against him. In this, however, he has totally failed.

The fact is certainly remarkable that, while in contemporary documents of unquestionable authority we find con-

* Bacon's Henry VII. in Kennet, vol. i. p. 624.

† Stow's Chronicles by Howe, edition 1631, p. 481 .

$\ddagger$ Speed's History of Great Britain, p. 744, edition 1511. In the edition of Speed's work published in 1632, there is no mention of the voyage of either of the Cabots 
meing proof of the discovery having been made by John Cabot, in none of the English annalists or historians who treat of the reign of Henry VII. do we see any account of the first voyage, while many of them have distinctly recorded the circumstances of the second. But of this it is not difficult to discover the reason. The first voyage was a private adventure or experiment by John Cabot, and probably little known or talked of beyond the city of Bristol. It was undertaken at the expense, not of the crown, but of the individual; and after having made the discovery, Cabot appears to have returned at once without exploring the coast, to make preparations for a voyage on a more extended scale. When he reached England, in the month of August, 1497 , being shortly after the commencement of the thirteenth year of Henry's reign, he found the sovereign and his kingdom in a state of extreme anxiety and confusion. The king was engrossed with an invasion of the Scots, with a formidable rebellion in Cornwall, and a new rising in favour of Warbeck, the leader of which threatened to pluck the crown from his head and give it to that adventurer, who, early in September, had landed from Ireland and assumed the title of Richard IV. It was upon these great events, the attacks of his enemies, and the measures adopted to defeat them,- - that the minds of the contemporary writers, and of the succeeding chroniclers and annalists, were naturally concentrated; and, engrossed with them, they paid little attention to the discovery of a private merchant of Bristol. It is for this reason, we apprehend, that we in vain look in Fabyan and in Stow for any detailed account or even incidental mention, of the discovery of 1497 .

The circumstances, however, under which the second voyage, in 1498 , took place, which all are agreed was conducted solely by Sebastian Cabot, were completely different. It was undertaken at the expense of the king, who furnished the ships; it contemplated a scheme of settlement and colonization, in which all the ardent and enterprising spirits in the nation were invited to co-operate. Many, there is reason to believe, did embark in the undertaking; and, instead of merely landing on the island and returning home, the voyage embraced the discovery of a large tract of coast, till that period unknown. If to this we add the consideration that, about the time when the second expedition must 
have returned to Bristol, the kingdom was in profound peace, both at home and abroad, it will not be difficult to understand why this voyage should constitute the event upon which the attention of our national annalists has been exclusively fixed; while the former, in which the discovery was undoubtedly made, has been passed over by them altogether. But although chroniclers and historians may fall into many errors of omission, the original muniments of the country and the period remain; and these, combined with the narrative upon the map and the inscription on the ancient portrait, completely establish the fact that John Cabot, the Venetian, was, in 1497, the discoverer of North America, under a commission from Henry VII. This portion of historical truth, which has hitherto certainly been surrounded with much obscurity and apparent contradiction, and of late absolutely denied by the biographer of Cabot, has now, we trust, been established upon grcunds which cannot easily be shaken. 

1
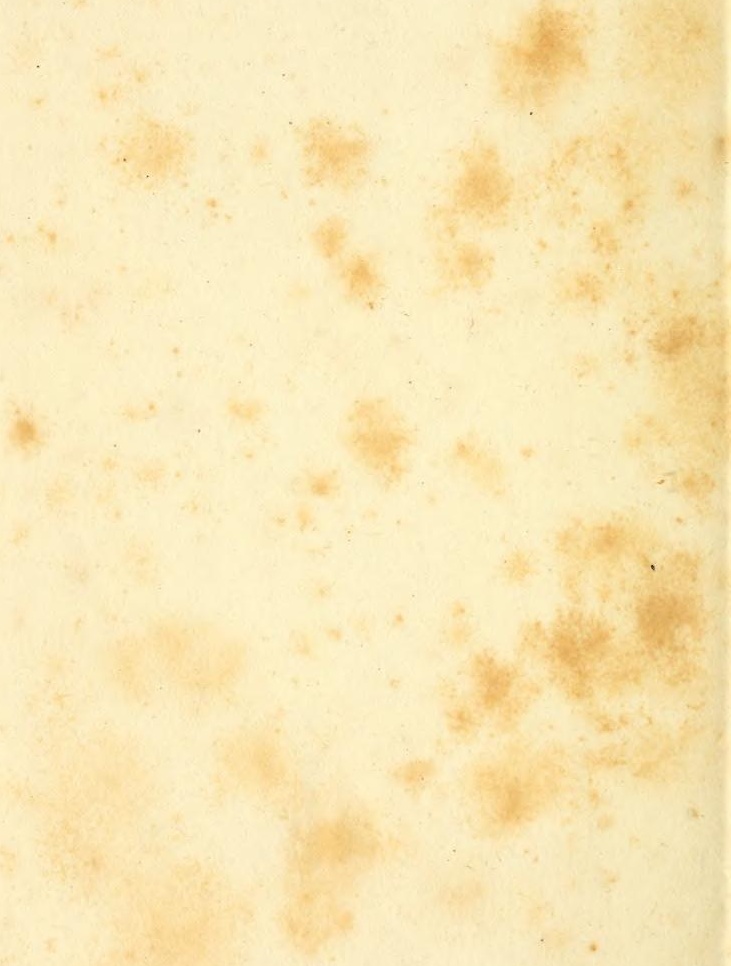
$x^{2}+2 x+2=5$

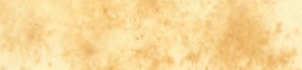

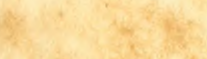

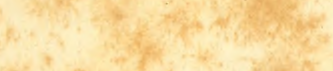

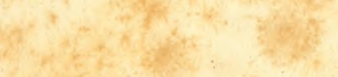

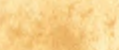

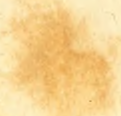

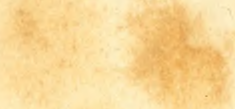

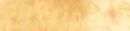

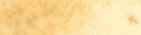

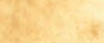

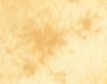

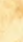

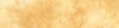

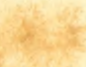

*

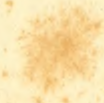

$x^{4}+$

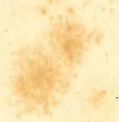

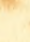<smiles>C1CCCC1</smiles>

$$
\begin{aligned}
& +y^{2}+20+4
\end{aligned}
$$

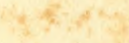

$$
\begin{aligned}
& -x^{2}
\end{aligned}
$$

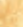

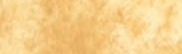

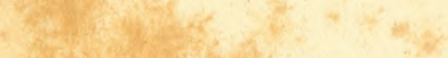

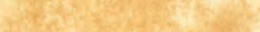

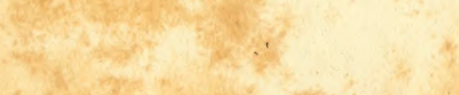

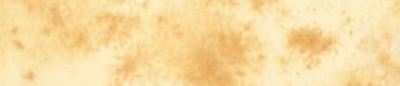

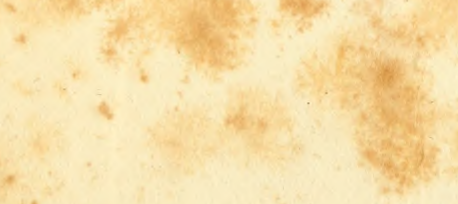


LIBRARY OF CONGRESS

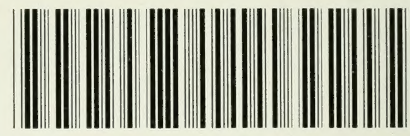

00173965709 